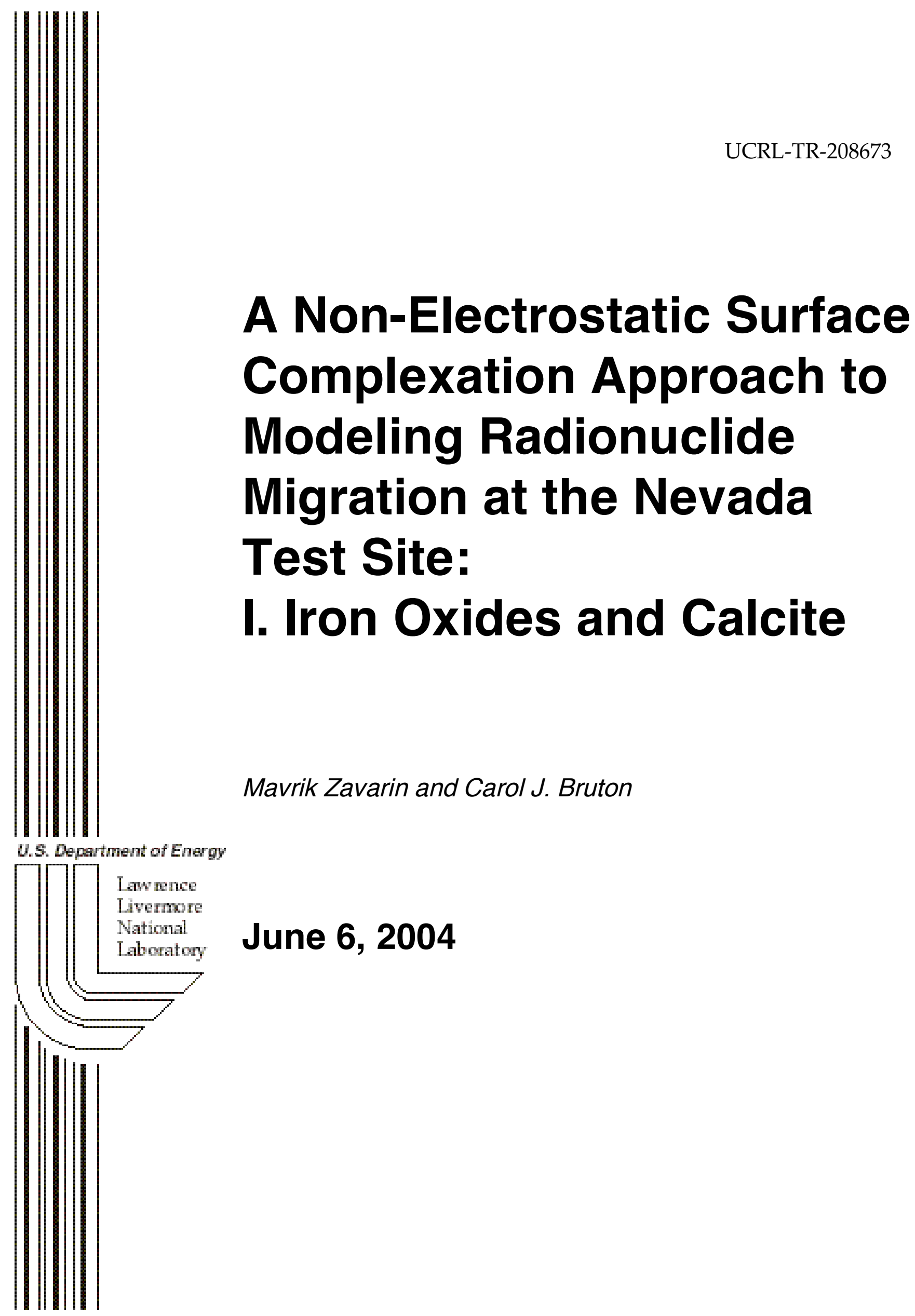




\section{DISCLAIMER}

This document was prepared as an account of work sponsored by an agency of the United States Government. Neither the United States Government nor the University of California nor any of their employees, makes any warranty, express or implied, or assumes any legal liability or responsibility for the accuracy, completeness, or usefulness of any information, apparatus, product, or process disclosed, or represents that its use would not infringe privately owned rights. Reference herein to any specific commercial product, process, or service by trade name, trademark, manufacturer, or otherwise, does not necessarily constitute or imply its endorsement, recommendation, or favoring by the United States Government or the University of California. The views and opinions of authors expressed herein do not necessarily state or reflect those of the United States Government or the University of California, and shall not be used for advertising or product endorsement purposes.

This work was performed under the auspices of the U.S. Department of Energy by the University of California, Lawrence Livermore National Laboratory under Contract No. W-7405-Eng-48.

This report has been reproduced directly from the best available copy.

Available to DOE and DOE contractors from the Office of Scientific and Technical Information P.O. Box 62, Oak Ridge, TN 37831-0062

Phone 865-576-8401

Fax 865-576-5726

Email reports@adonis.osti.gov

Available to the public from the National Technical Information Service

U.S. Department of Commerce 5285 Port Royal Rd., Springfield, VA 22161

Phone 800-553-6847

Fax 703-605-6900

Email orders@ntis.gov

Online ordering http://www.ntis.gov/ordering.htm

OR

Lawrence Livermore National Laboratory

Technical Information Department's Digital Library

http://www.llnl.gov/tid/Library.html 


\title{
A Non-Electrostatic Surface Complexation Approach to Modeling Radionuclide Migration at the Nevada Test Site: \\ I. Iron Oxides and Calcite
}

\author{
Mavrik Zavarin and Carol J. Bruton \\ Lawrence Livermore National Laboratory \\ Livermore, California
}

\author{
Prepared for the Underground Test Area Project \\ U.S. Department of Energy \\ National Nuclear Security Administration \\ Nevada Site Office
}

Final Report

June 2004 



\section{TABLE OF CONTENTS}

SUMMARY .......................................................................................................... 1

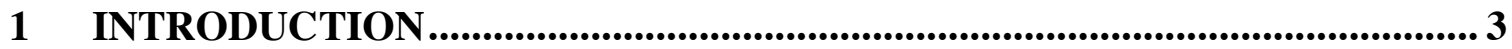

2 NON-ELECTROSTATIC MODEL DATABASE

CONSTRUCTION ........................................................................... 5

3 SORPTION DATA FITTING RESULTS ...................................................... 8

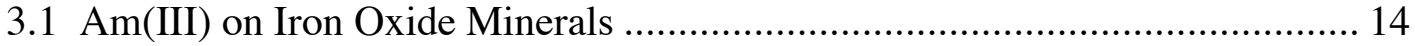

3.2 Am(III) on Calcite ........................................................................... 16

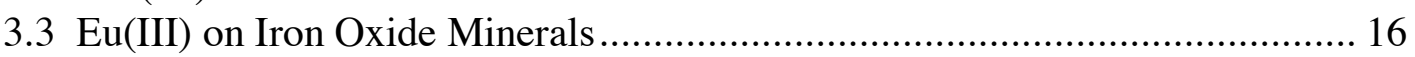

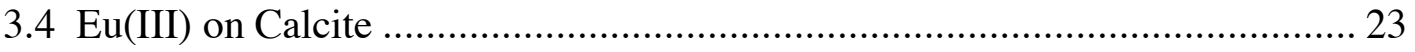

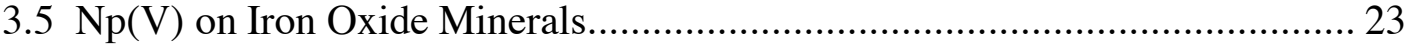

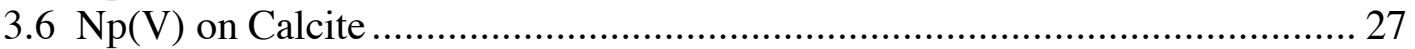

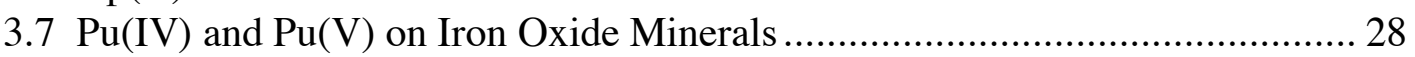

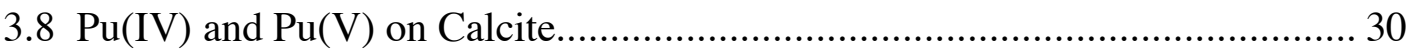

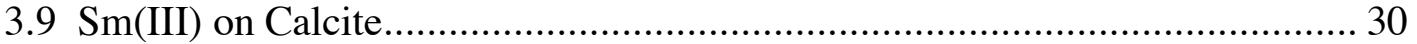

$3.10 \mathrm{Sr}(\mathrm{II})$ on Iron Oxide Minerals ............................................................. 31

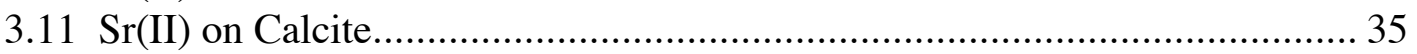

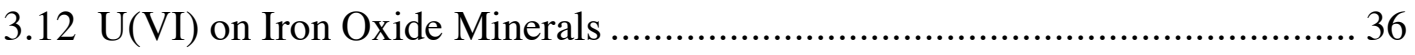

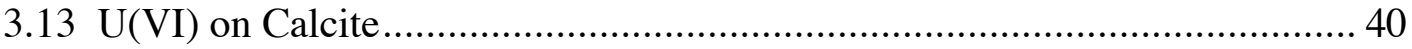

4 SUMMARY OF NON-ELECTROSTATIC MODEL

DATABASE.............................................................................................. 41

4.1 Radionuclide Sorption to Iron Oxide Minerals......................................... 41

4.2 Radionuclide Sorption to Carbonate Minerals.......................................... 46

5 1D REACTIVE TRANSPORT SIMULATIONS - THE ROLE OF CALCITE AND IRON OXIDE IN RADIONUCLIDE

RETARDATION ........................................................................................... 51

6 CONCLUSIONS ........................................................................................... 61

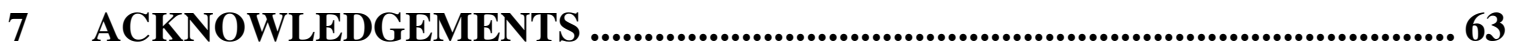

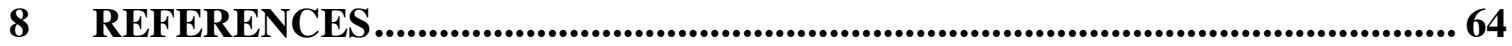

APPENDIX A. REPORT ON SORPTION DATA COLLECTED

FOR THE UGTA PROGRAM IN FY 2000 ................................................... 68

APPENDIX B. DATA COLLECTED FOR THE UGTA PROJECT

IN CONJUNCTION WITH THE HYDROLOGIC

RESOURCES MANAGEMENT PROGRAM IN FY 2000............................. 98

APPENDIX C. AQUEOUS SPECIATION DATA USED IN DATA

FITTING ROUTINES 


\section{LIST OF FIGURES}

Figure 1. Sorption of $\mathrm{Am}(\mathrm{III})$ on $\alpha-\mathrm{Fe}_{2} \mathrm{O}_{3}$. Solid lines represent model prediction using NEM constants from Table 2. $\mathrm{I}=0.001$ (black), 0.01 (red), 0.1 (blue), 1 (green); $8 \times 10^{-9} \mathrm{~mol} / \mathrm{L} \mathrm{Am(III);} 25 \mathrm{mg} / \mathrm{L} \mathrm{Fe}_{2} \mathrm{O}_{3} ; 19 \mathrm{~m}^{2} / \mathrm{g}$ $\mathrm{Fe}_{2} \mathrm{O}_{3}$; data from Cromieres (1996); dashed lines = individual species contributions.

Figure 2. Sorption of $\mathrm{Am}(\mathrm{III})$ on $\alpha-\mathrm{Fe}_{2} \mathrm{O}_{3}$. Solid lines represent model prediction using NEM constants from Table 2. $\mathrm{I}=0.1 ; 8 \times 10^{-9} \mathrm{~mol} / \mathrm{L}$ Am(III); 12.5 (black), 25 (red), 125 (blue) $\mathrm{mg} / \mathrm{L} \mathrm{Fe}_{2} \mathrm{O}_{3} ; 19 \mathrm{~m}^{2} / \mathrm{g} \mathrm{Fe}_{2} \mathrm{O}_{3}$; data from Cromieres (1996).

Figure 3. Sorption of $\mathrm{Am}(\mathrm{III})$ on $\alpha-\mathrm{Fe}_{2} \mathrm{O}_{3}$. Solid lines represent model prediction using NEM constants from Table $2 . \mathrm{I}=0.1 ; 8 \times 10^{-9}$ (black), $1.5 \times 10^{-9}$ (red) $\mathrm{mol} / \mathrm{L} \mathrm{Am}(\mathrm{III}) ; 25 \mathrm{mg} / \mathrm{L} \mathrm{Fe}_{2} \mathrm{O}_{3} ; 19 \mathrm{~m}^{2} / \mathrm{g} \mathrm{Fe}_{2} \mathrm{O}_{3}$; data from Cromieres (1996).

Figure 4. Sorption of $\mathrm{Am}(\mathrm{III})$ on $\alpha-\mathrm{Fe}_{2} \mathrm{O}_{3}$. Solid lines represent model prediction using NEM constants from Table $2 . \quad \mathrm{I}=0.1 ; 8 \times 10^{-9} \mathrm{~mol} / \mathrm{L}$ Am(III); 100 (black), 125 (red) mg/L Fe $\mathrm{O}_{3} ; 8$ (black), 19 (red) $\mathrm{m}^{2} / \mathrm{g}$ $\mathrm{Fe}_{2} \mathrm{O}_{3}$; data from Cromieres (1996). 16

Figure 5. Sorption of $\mathrm{Eu}(\mathrm{III})$ on $\mathrm{FeOOH}$. Solid lines represent model prediction using NEM constants from Table $2 . \mathrm{I}=0.01 ; 10^{-8} \mathrm{~mol} / \mathrm{L}$ $\mathrm{Eu}(\mathrm{III}) ; 250 \mathrm{mg} / \mathrm{L} \mathrm{FeOOH} ; 62 \mathrm{~m}^{2} / \mathrm{g} \mathrm{FeOOH}$; data from Ledin et al. (1994).

Figure 6. Sorption of $\mathrm{Eu}(\mathrm{III})$ on $\mathrm{Fe}(\mathrm{OH})_{3}$. Solid lines represent model prediction using NEM constants from Table $2 . \quad \mathrm{I}=0.01 ; 10^{-8} \mathrm{~mol} / \mathrm{L}$ $\mathrm{Eu}(\mathrm{III}) ; 50 \mathrm{mg} / \mathrm{L} \mathrm{Fe}(\mathrm{OH})_{3} ; 320 \mathrm{~m}^{2} / \mathrm{g} \mathrm{Fe}(\mathrm{OH})_{3}$; data from Ledin et al. (1994).

Figure 7. Sorption of $\mathrm{Eu}(\mathrm{III})$ on $\mathrm{Fe}_{2} \mathrm{O}_{3}$. Solid lines represent model prediction using NEM constants from Table $2 . \mathrm{I}=0.01 ; 10^{-8} \mathrm{~mol} / \mathrm{L}$ $\mathrm{Eu}(\mathrm{III}) ; 500 \mathrm{mg} / \mathrm{L} \mathrm{Fe}_{2} \mathrm{O}_{3} ; 43 \mathrm{~m}^{2} / \mathrm{g} \mathrm{Fe}_{2} \mathrm{O}_{3}$; data from Ledin et al. (1994).

Figure 8. Sorption of $\mathrm{Eu}(\mathrm{III})$ on $\mathrm{Fe}_{2} \mathrm{O}_{3}$. Solid lines represent model prediction using NEM constants from Table $2 . \quad I=0.1 ; 1.79 \times 10^{-5} \mathrm{~mol} / \mathrm{L}$ $\mathrm{Eu}(\mathrm{III}) ; 1.02 \times 10^{-4} \mathrm{~mol} / \mathrm{L} \mathrm{Fe}_{2} \mathrm{O}_{3}$ sites; data from Rabung et al. (1998)....

Figure 9. Sorption of $\mathrm{Eu}(\mathrm{III})$ on $\mathrm{Fe}_{2} \mathrm{O}_{3}$. Solid lines represent model prediction using NEM constants from Table $2 . \mathrm{I}=0.1 ; 1.79 \times 10^{-6} \mathrm{~mol} / \mathrm{L}$ $\mathrm{Eu}(\mathrm{III}) ; 1.02 \times 10^{-4} \mathrm{~mol} / \mathrm{L} \mathrm{Fe}_{2} \mathrm{O}_{3}$ sites; data from Rabung et al. (1998).

Figure 10. Sorption of $\mathrm{Eu}(\mathrm{III})$ on $\mathrm{Fe}_{2} \mathrm{O}_{3}$ at $\mathrm{pH} 4$ as a function of added $\mathrm{Eu}(\mathrm{III})$ (aqueous $\mathrm{Eu}<10^{-5} \mathrm{~mol} / \mathrm{L}$ ) at low surface loads. Solid lines represent model prediction using NEM constants from Table 2. $\mathrm{I}=0.1$; $1.02 \times 10^{-4} \mathrm{~mol} / \mathrm{L} \mathrm{Fe}_{2} \mathrm{O}_{3}$ sites; data from Rabung et al. (1998). 
Figure 11. Sorption of $\mathrm{Eu}(\mathrm{III})$ on $\mathrm{Fe}_{2} \mathrm{O}_{3}$ at $\mathrm{pH} 5$ as a function of added $\mathrm{Eu}(\mathrm{III})$ (aqueous $\mathrm{Eu}<10^{-5} \mathrm{~mol} / \mathrm{L}$ ) at low surface loads. Solid lines represent model prediction using NEM constants from Table 2. $\mathrm{I}=0.1$; $1.02 \times 10^{-4} \mathrm{~mol} / \mathrm{L} \mathrm{Fe}_{2} \mathrm{O}_{3}$ sites; data from Rabung et al. (1998).

Figure 12. Sorption of $\mathrm{Eu}(\mathrm{III})$ on $\mathrm{Fe}_{2} \mathrm{O}_{3}$ at $\mathrm{pH} 5.5$ as a function of added $\mathrm{Eu}(\mathrm{III})$ (aqueous $\mathrm{Eu}<10^{-5} \mathrm{~mol} / \mathrm{L}$ ) at low surface loads. Solid lines represent model prediction using NEM constants from Table 2. $\mathrm{I}=0.1$; $1.02 \times 10^{-4} \mathrm{~mol} / \mathrm{L} \mathrm{Fe}_{2} \mathrm{O}_{3}$ sites; data from Rabung et al. (1998).

Figure 13. Sorption of $\mathrm{Eu}(\mathrm{III})$ on $\mathrm{Fe}_{2} \mathrm{O}_{3}$ at $\mathrm{pH} 6$ as a function of added $\mathrm{Eu}(\mathrm{III})$ (aqueous $\mathrm{Eu}<10^{-5} \mathrm{~mol} / \mathrm{L}$ ) at low surface loads. Solid lines represent model prediction using NEM constants from Table 2. $\mathrm{I}=0.1$; $1.02 \times 10^{-4} \mathrm{~mol} / \mathrm{L} \mathrm{Fe}_{2} \mathrm{O}_{3}$ sites; data from Rabung et al. (1998).

Figure 14. Sorption of $4.5 \times 10^{-11}$ (black), $4.7 \times 10^{-12}$ (red), and $4.5 \times 10^{-13}$ (blue) $\mathrm{mol} / \mathrm{L} \mathrm{Np}(\mathrm{V})$ on $\mathrm{Fe}(\mathrm{OH})_{3}$. Solid lines represent model prediction using NEM constants from Table $2 . \mathrm{I}=0.1 ; 10^{-2} \mathrm{~mol} / \mathrm{L} \mathrm{Fe}$ as $\mathrm{Fe}(\mathrm{OH})_{3}$; open to air; data from Girvin et al. (1991).

Figure 15. Sorption of $\mathrm{Np}(\mathrm{V})$ on $\mathrm{Fe}(\mathrm{OH})_{3}$. Solid lines represent model prediction using NEM constants from Table $2 . \mathrm{I}=0.1 ; \mathrm{Np}(\mathrm{V})=4.7 \times 10^{-12}$ $\mathrm{mol} / \mathrm{L} ; 0.001$ (black), 0.0037 (red), and 0.01 (blue) mol/L Fe as $\mathrm{Fe}(\mathrm{OH})_{3}$; open to air; data from Girvin et al. (1991); dashed lines = individual species contributions.

Figure 16. Sorption of $\mathrm{Np}(\mathrm{V})$ on natural $\mathrm{FeOOH}$. Solid lines represent model prediction using NEM constants from Table 2 with total carbonate $\sim 5 \times 10^{-5} \mathrm{~mol} / \mathrm{L}$ (solid line) and $\mathrm{pCO}_{2}=3.5$ (dashed line). $\mathrm{I}=0.1 ; 6 \times 10^{-6}$ $\mathrm{mol} / \mathrm{L} \mathrm{Np}(\mathrm{V}) ; 1 \mathrm{~g} / \mathrm{L} \mathrm{FeOOH} ; 15.7 \mathrm{~m}^{2} / \mathrm{g} \mathrm{FeOOH}$; open to air; data from Nakayama and Sakamoto (1991).

Figure 17. Sorption of $\mathrm{Np}(\mathrm{V})$ on synthetic $\gamma$-FeOOH. Solid lines represent model prediction using NEM constants from Table 2 with total carbonate $\sim 5 \times 10^{-5} \mathrm{~mol} / \mathrm{L}$ (solid line) and $\mathrm{pCO}_{2}=3.5$ (dashed line). $\mathrm{I}=0.1$; $6 \times 10^{-6} \mathrm{~mol} / \mathrm{L} \mathrm{Np}(\mathrm{V}) ; 1 \mathrm{~g} / \mathrm{L} \mathrm{FeOOH} ; 15.7 \mathrm{~m}^{2} / \mathrm{g} \mathrm{FeOOH}$; open to air; data from Nakayama and Sakamoto (1991).

Figure 18. Sorption of $\mathrm{Np}(\mathrm{V})$ on calcite. Solid lines represent model prediction using NEM constants from Table 3. Dashed line represent fit based on the calcite surface model of Van Cappellen et al. (1993). I = 0.1; $6 \times 10^{-6} \mathrm{~mol} / \mathrm{L} \mathrm{Np}(\mathrm{V}) ; 1 \mathrm{~g} / \mathrm{L}$ calcite; $15.7 \mathrm{~m}^{2} / \mathrm{g}$ calcite; open to air; data from Appendix A.

Figure 19. Sorption of $10^{-10}$ (black) and $10^{-11}$ (red) mol/L Pu(IV) on FeOOH. Solid lines represent model prediction using NEM constants from Table 2. I = 0.1; $28.5 \mathrm{~m}^{2} / \mathrm{L}$ as FeOOH; data from Sanchez et al. (1985); dashed lines $=$ individual species contributions. 
Figure 20. Sorption of $10^{-10}$ (black) and $10^{-11}$ (red) $\mathrm{mol} / \mathrm{L} \mathrm{Pu}(\mathrm{V})$ on $\mathrm{FeOOH}$. Solid lines represent model prediction using NEM constants from Table 2. I $=0.1 ; 28.5 \mathrm{~m}^{2} / \mathrm{L}$ as FeOOH; data from Sanchez et al. (1985); dashed lines $=$ individual species contributions.

Figure 21. Sorption of $\mathrm{Sr}(\mathrm{II})$ on $\mathrm{Fe}(\mathrm{OH})_{3}$. Solid lines represent model prediction using NEM constants from Table $3 . \mathrm{I}=1 ; 2 \times 10^{-6} \mathrm{~mol} / \mathrm{L} \mathrm{Sr}(\mathrm{II})$; $9.24 \times 10^{-2} \mathrm{~mol} / \mathrm{L} \mathrm{Fe}$ as $\mathrm{Fe}(\mathrm{OH})_{3}$; open to air; data from Kinniburgh et al. (1975); dashed lines $=$ individual species contributions.

Figure 22. Comparison of $\mathrm{Sr}^{2+}$ activity coefficient as a function of ionic strength using the Davies model and the Extended Debye-Huckel model

Figure 23. Sorption of $10^{-7}$ (black circle), $8.34 \times 10^{-6}$ (red circle), $8.34 \times 10^{-5}$ (blue circle), $10^{-3}$ (green circle), $5 \times 10^{-3}$ (black diamond), $10^{-2}$ (red diamond), and $5 \times 10^{-2}$ (blue diamond) $\mathrm{mol} / \mathrm{L} \mathrm{Sr}(\mathrm{II})$ on $\mathrm{Fe}(\mathrm{OH})_{3}$. Solid lines represent model prediction using NEM constants from Table 2. I=1; $10^{-1} \mathrm{~mol} / \mathrm{L} \mathrm{Fe}$ as $\mathrm{Fe}(\mathrm{OH})_{3}$; open to air; data from Kolarik (1961).

Figure 24. Sorption of $\mathrm{Sr}$ (II) on $2 \times 10^{-2}$ (black), $5 \times 10^{-2}$ (red), $10^{-1}$ (blue), and $2 \times 10^{-1}$ (green) $\mathrm{mol} / \mathrm{L} \mathrm{Fe}$ as $\mathrm{Fe}(\mathrm{OH})_{3}$. Solid lines represent model prediction using NEM constants from Table $2 . \mathrm{I}=1 ; 10^{-7} \mathrm{~mol} / \mathrm{L} \mathrm{Sr}(\mathrm{II})$; open to air; data from Kolarik (1961).

Figure 25. Sorption of $\mathrm{Sr}(\mathrm{II})$ on $\mathrm{CaCO}_{3}$. Solid lines represent model prediction using NEM constants from Table $3 . \mathrm{I}=0.1 ; 10^{-7} \mathrm{~mol} / \mathrm{L} \mathrm{Sr}(\mathrm{II})$; $25 \mathrm{~g} / \mathrm{L} \mathrm{CaCO}_{3} ; 3.6 \times 10^{-6} \mathrm{~mol}$ sites $/ \mathrm{g}$; open to air; data from Zachara et al. (1991).

Figure 26. Sorption of $\mathrm{U}(\mathrm{VI})$ on $\mathrm{Fe}_{2} \mathrm{O}_{3}$ (no $\mathrm{CO}_{2}(\mathrm{~g})$ ). Solid lines represent model prediction using NEM constants from Table 2. $\mathrm{I}=0.01 ; \mathrm{U}(\mathrm{VI})=$ $2 \times 10^{-6} \mathrm{~mol} / \mathrm{L} ; 1 \mathrm{~g} / \mathrm{L} \mathrm{Fe}_{2} \mathrm{O}_{3}$; and $1.5 \mathrm{~m}^{2} / \mathrm{g} \mathrm{Fe}_{2} \mathrm{O}_{3}$; data from Viani and Torretto (1998).

Figure 27. Sorption of U(VI) on FeOOH at $10^{-3}$ (black) and $10^{-2}$ (red) $\mathrm{mol} / \mathrm{L}$ total carbonate. Solid lines represent model prediction using NEM constants from Table 2 . I $=0.1 ; 10^{-5} \mathrm{~mol} / \mathrm{L} \mathrm{U}(\mathrm{VI}) ; 1 \mathrm{~g} / \mathrm{L} \mathrm{FeOOH} ; 50 \mathrm{~m}^{2} / \mathrm{g}$ $\mathrm{FeOOH}$; data from Hsi and Langmuir (1985).

Figure 28. Sorption of $\mathrm{U}(\mathrm{VI})$ on $\mathrm{Fe}(\mathrm{OH})_{3}$ (black), $\mathrm{FeOOH}$ (red), synthetic $\mathrm{Fe}_{2} \mathrm{O}_{3}$ (blue), and natural $\mathrm{Fe}_{2} \mathrm{O}_{3}$ (green). Solid lines represent model prediction using NEM constants from Table $2 . \mathrm{I}=0.1 ; 10^{-5} \mathrm{~mol} / \mathrm{L} \mathrm{U}(\mathrm{VI})$; $1 \mathrm{~g} / \mathrm{L}$ solid; $600 \mathrm{~m}^{2} / \mathrm{g} \mathrm{Fe}(\mathrm{OH})_{3} ; 50 \mathrm{~m}^{2} / \mathrm{g} \mathrm{FeOOH} ; 7.2 \mathrm{~m}^{2} / \mathrm{g}$ syn. $\mathrm{Fe}_{2} \mathrm{O}_{3} ; 4.2$ $\mathrm{m}^{2} / \mathrm{g}$ nat. $\mathrm{Fe}_{2} \mathrm{O}_{3}$; data from $\mathrm{Hsi}$ and Langmuir (1985).

Figure 29. Sorption of $\mathrm{U}(\mathrm{VI})$ on $\mathrm{Fe}(\mathrm{OH})_{3}$ at $\mathrm{I}=0.02$ (black) and $\mathrm{I}=0.5$ (red). Solid lines represent model prediction using NEM constants from Table 2. $\mathrm{U}(\mathrm{VI})=10^{-6} \mathrm{~mol} / \mathrm{L} ; 10^{-3} \mathrm{~mol} / \mathrm{L} \mathrm{Fe}$ as $\mathrm{Fe}(\mathrm{OH})_{3}$; open to air; data from Waite et al. (1994). 
Figure 30. Sorption of $\mathrm{U}(\mathrm{VI})$ on $\mathrm{Fe}(\mathrm{OH})_{3}$ at 0.02 (black) and 0.001 (red) $\mathrm{mol} / \mathrm{L} \mathrm{Fe}$ as $\mathrm{Fe}(\mathrm{OH})_{3}$. Solid lines represent model prediction using NEM constants from Table 2 . $\mathrm{I}=0.1 ; 10^{-6} \mathrm{~mol} / \mathrm{L} \mathrm{U}(\mathrm{VI})$; open to air; data from Waite et al. (1994).

Figure 31. Sorption of $10^{-5}$ (black), $10^{-6}$ (red), and $10^{-8}$ (blue) $\mathrm{mol} / \mathrm{L} \mathrm{U}(\mathrm{VI})$ on $\mathrm{Fe}(\mathrm{OH})_{3}$. Solid lines represent model prediction using NEM constants from Table $2 . \mathrm{I}=0.1 ; 10^{-3} \mathrm{~mol} / \mathrm{L} \mathrm{Fe}$ as $\mathrm{Fe}(\mathrm{OH})_{3}$; open to air (except $10^{-6}$ $\mathrm{mol} / \mathrm{L} \mathrm{U}(\mathrm{VI})$ samples at $\left.1 \% \mathrm{CO}_{2}(\mathrm{~g})\right)$; data from Waite et al. (1994).

Figure 32. Sorption of U(VI) on $\mathrm{FeOOH}$ at $0.2 \%$ (black), $5 \%$ (red), and $90 \%$ (blue) $\mathrm{CO}_{2}(\mathrm{~g})$ partial pressure (1 atm). Solid lines represent model prediction using NEM constants from Table 2. Dashed lines represent individual contributions of two surface species for samples at $90 \% \mathrm{CO}_{2}(\mathrm{~g})$. $\mathrm{I}=0.1$, total $\mathrm{U}(\mathrm{VI})=8.4 \times 10^{-6} \mathrm{~mol} / \mathrm{L}, 8 \mathrm{~g} / \mathrm{L} \mathrm{FeOOH}$, and $60 \mathrm{~m}^{2} / \mathrm{g} \mathrm{FeOOH}$. Data from Duff and Amrhein (1996).

Figure 33. Oxidation states of dominant sorbed (dashed lines) and aqueous (solid lines) $\mathrm{Pu}$ species at $177 \mathrm{mg} / \mathrm{L}$ carbonate alkalinity and 0.2 bar $\mathrm{O}_{2}(\mathrm{~g})$ fugacity. Solution conditions similar to those of Sanchez et al. (1985) with $10^{-11} \mathrm{~mol} / \mathrm{L} \mathrm{Pu}$

Figure 34. Oxidation states of dominant sorbed (dashed lines) and aqueous (solid lines) Pu species at $177 \mathrm{mg} / \mathrm{L}$ carbonate alkalinity and $\mathrm{O}_{2}(\mathrm{~g})$ fugacity of $10^{-10}$ bars. Solution conditions similar to those of Sanchez et al. (1985) with $10^{-11} \mathrm{~mol} / \mathrm{L} \mathrm{Pu}$

Figure 35. Aqueous concentration of Pu in Four REACT model runs using solution conditions of Sanchez et al. (1985). For each model run, all solution conditions were identical except for the change in $\mathrm{O}_{2}(\mathrm{~g})$ fugacity (as listed in figure)....

Figure 36. Distribution of dominant Am(III) aqueous species and surface complexes at 500 years.

Figure 37. Distribution of Cs(I) aqueous and sorbed species at 500 years. Cs-ill\# = Cs bound to 3 sites of illite $/ \mathrm{mica}$; Cs-clin = Cs on clinoptilolite;

Cs-smec $=$ Cs on smectite

Figure 38. Distribution of dominant $\mathrm{Eu}(\mathrm{III})$ aqueous species and surface complexes at 500 years.

Figure 39. Distribution of dominant $\mathrm{Np}(\mathrm{V})$ aqueous species and surface complexes at 500 years.

Figure 40. Distribution of dominant $\mathrm{Pu}$ aqueous species and surface complexes at 500 years $\left(\mathrm{O}_{2}(\mathrm{~g})\right.$ fugacity set to 0.2 bars $)$. Dominant aqueous species for each oxidation state are shown.

Figure 41. Distribution of dominant $\mathrm{Pu}$ aqueous species and surface complexes at 500 years $\left(\mathrm{O}_{2}(\mathrm{~g})\right.$ fugacity set to $10^{-7}$ bars $)$. Dominant aqueous species for each oxidation state are shown. 
Figure 42. Distribution of dominant $\mathrm{Sm}(\mathrm{III})$ aqueous species and surface complexes at 500 years.

Figure 43. Distribution of $\operatorname{Sr}($ II) aqueous species and surface complexes at 500 years.

Figure 44. Distribution of dominant $U$ aqueous species and surface complexes at 500 years.

Figure 45. Distribution of dominant $U$ aqueous species and surface complexes at 500 years ( $\log K$ for $U$ sorption on calcite and iron oxide reduced by 1$)$.

Figure B.1 Speciation of $\mathrm{Pu}(\mathrm{V})$ under conditions of calcite sorption experiments.

Figure B.2 Speciation of $\mathrm{Pu}(\mathrm{IV})$ under conditions of calcite sorption experiments.

Figure B.3 Sorption data for $\mathrm{Pu}(\mathrm{IV})$ on calcite at 7 days. Dashed line represents the initial aqueous concentration in solution $\left(5 \times 10^{-9} \mathrm{~mol} / \mathrm{L}\right)$. The curve represents the fit to the sorption data using the non-elecrostatic model

Figure B.4 Sorption data for $\mathrm{Pu}(\mathrm{V})$ on calcite at 7 days. Dashed line represents the initial aqueous concentration in solution $\left(1 \times 10^{-7} \mathrm{~mol} / \mathrm{L}\right)$. The curve represents the fit to the sorption data using the non-electrostatic surface exchange model. 


\section{LIST OF TABLES}

Table 1. List of sorption data sets used in this study and their nonelectrostatic model reaction constant fits.

Table 2. Average non-electrostatic surface complexation constants for radionuclide interaction with iron oxides.

Table 3. Average non-electrostatic surface exchange constants for radionuclide interaction with calcite.

Table 4. Comparison of non-electrostatic model fits to calcite sorption and coprecipitation data for selected radionuclides. ${ }^{\mathrm{a}}$

Table 5. Composition of alluvium mineralogy and water chemistry used in a generic Frenchman Flat reactive transport simulation based on information in Tompson et al. (1999).

Table 6. Ion exchange reactions used in GIMRT 1D simulations. Data taken from Viani and Bruton (1992; 1996).

Table 7. Radionuclide-mineral associations considered significant based on $1 \mathrm{D}$ reactive transport simulations.

Table B.1. Best fit parameters for Pu sorption to calcite.

Table C.1. Basis species used in thermodynamic database. 105

Table C.2. Parameters in extended Debye-Huckel activity coefficient model and Davies activity coefficient models

Table C.3. Logarithm of equilibrium constants $(\mathrm{K})$ of aqueous reactions at $25^{\circ} \mathrm{C}$. 106 


\section{SUMMARY}

Reliable quantitative prediction of contaminant transport in subsurface environments is critical to evaluating the risks associated with radionuclide migration. As part of the Underground Test Area (UGTA) project, radionuclide transport away from various underground nuclear tests conducted in the saturated zone at the Nevada Test Site (NTS) is being examined. In the near-field environment, reactive transport simulations must account for changes in water chemistry and mineralogy as a function of time and their effect on radionuclide migration. Unlike the $K_{d}$ approach, surface complexation (SC) reactions, in conjunction with ion exchange and precipitation, can be used to describe radionuclide reactive transport as a function of changing environmental conditions. They provide a more robust basis for describing radionuclide retardation in geochemically dynamic environments.

The interaction between several radionuclides considered relevant to the UGTA project and iron oxides ${ }^{1}$ and calcite are examined in this report. The interaction between these same radionuclides and aluminosilicate minerals is examined in a companion report (Zavarin and Bruton, 2004). Selection criteria for radionuclides were based on abundance, half-life, toxicity to human and environmental health, and potential mobility at NTS (Tompson et al., 1999). Both iron oxide and calcite minerals are known to be present at NTS in various locations and are likely to affect radionuclide migration from the near-field. Modeling the interaction between radionuclides and these minerals was based on surface complexation. The effectiveness of the most simplified SC model, the one-site Non-Electrostatic Model (NEM), to describe sorption under various solution conditions is evaluated in this report.

NEM reactions were fit to radionuclide sorption data available in the literature, as well as sorption data recently collected for the UGTA project, and a NEM database was developed. For radionuclide-iron oxide sorption, simple binary NEM reactions adequately fit most data without need for bidentate or ternary surface reactions. For example, the decrease in U(VI) sorption as a function of carbonate alkalinity was accounted for by aqueous uranyl-carbonate complex formation. In some cases, the onesite NEM could not fit sorption data at high and low radionuclide surface loads. This failure results from multiple surface sites with varying sorption affinity as well as electrostatic effects not accounted for by our model.

Calcite sorption reactions were modeled as NEM surface exchange reactions. Uncertainty in these surface exchange reactions is relatively high because few radionuclide-calcite sorption data are available. Nevertheless, 1D reactive transport simulations in alluvium comparable to that in Tompson et al. (1999) and based on the NEM database developed in this report, suggest that migration of $\mathrm{Sm}(\mathrm{III}), \mathrm{Eu}(\mathrm{III}), \mathrm{Np}(\mathrm{V})$, $\mathrm{Pu}(\mathrm{IV}, \mathrm{V})$, and $\mathrm{Am}(\mathrm{III})$ will be significantly retarded by sedimentary carbonates. Though

\footnotetext{
${ }^{1}$ In this report, we use the term "iron oxide" to define the group of minerals that include oxides and hydroxides of iron. This group includes goethite, hematite, lepidocrocite, ferrihydrite, maghemite, and magnetite.
} 
iron oxide minerals are usually thought to be the major contributors to radionuclide retardation, calcite will also be of paramount importance in areas where it is present (e.g. calcareous regions of NTS as well as buried carbonate paleosols at the 200 Area of the Hanford Site (south-central Washington, U.S.A.), calcareous soils of the Marshall Islands, and weathered cementitious materials at waste disposal facilities). The NEM approach provides a simple yet robust mechanistic basis for modeling radionuclide migration with a minimum number of fitting parameters. 


\section{INTRODUCTION}

Minerals that exhibit variable surface charge (e.g. goethite, calcite, etc.) can significantly reduce radionuclide mobility in the environment. The reduced mobility is partly a result of surface complexation (SC) reactions: reactions involving mineral surface functional groups and aqueous species. ${ }^{2}$ A typical SC reaction and associated equilibrium constant can be written in the following manner:

$>\mathrm{FeOH}+\mathrm{Sr}^{2+} \Leftrightarrow>\mathrm{FeOSr}^{+}+\mathrm{H}^{+}$

$K=\frac{\left(>\mathrm{FeOSr}^{+}\right)\left(\mathrm{H}^{+}\right)}{(>\mathrm{FeOH})\left(\mathrm{Sr}^{2+}\right)}$

where $>\mathrm{FeOH}$ is a surface functional group (for iron oxide), $\mathrm{Sr}^{2+}$ is an aqueous strontium species that reacts with the surface (to form $>\mathrm{FeOSr}^{+}$), and $\mathrm{H}^{+}$is released as a result of the reaction. Just as for simple aqueous complexation reactions, the above $\mathrm{SC}$ reaction has an equilibrium reaction constant, $K$, that describes the relative activity of all species at equilibrium.

In many sorption studies, distribution coefficients $\left(K_{d} \mathrm{~s}\right)$ are used to model sorption. $K_{d} \mathrm{~s}$ are typically reported as a ratio of total sorbed concentration $(\mathrm{mol} / \mathrm{g})$ to total aqueous concentration $(\mathrm{mol} / \mathrm{mL})$. The $K_{d}$ approach relies on the assumption that the ratio of sorbed to aqueous concentration for a particular radionuclide is constant (i.e. linear sorption). Although a $K_{d}$ can adequately describe the sorption behavior of a radionuclide in a particular sediment at a particular $\mathrm{pH}$ and solution composition, the many factors that alter radionuclide sorption in geochemically dynamic environments cannot be predicted using this approach. The SC reactions (as written in Equation 1) do not have this limitation, as will be discussed below.

Factors that influence radionuclide surface complexation on a particular mineral and, thus, affect radionuclide migration include:

- Surface area

- $\mathrm{pH}$

- Aqueous complexation

- Ionic strength

- Surface electrical charge

\footnotetext{
${ }^{2}$ Other reactions such as ion exchange and precipitation can also affect migration but are not discussed here.
} 
Since SC reactions occur at the mineral-water interface, surface complexation will be a function of the mineral surface area available for reaction. The $\mathrm{pH}$ can significantly affect surface complexation as well. For example, in Equation 1, as the concentration of $\mathrm{H}^{+}$increases, a larger fraction of $\mathrm{Sr}^{2+}$ will remain in solution. Surface functional groups (e.g. $>\mathrm{FeOH}$ ) may also become protonated/deprotonated as a function of $\mathrm{pH}$ which will affect surface complexation. Aqueous complexation will influence the concentration of aqueous species in solution; this will also affect surface complexation. For example, uranium surface complexation decreases as a function of carbonate concentration in solution due to the formation of uranyl carbonate complexes (uranyl carbonate complexes remain primarily in the aqueous phase). Ionic strength may influence surface complexation by reducing the effective concentration (i.e. activity) of aqueous species. Surface complexes as well as surface protonation and deprotonation may alter the electrostatics of the surface which can, in turn, influence surface complexation. Unlike $K_{d} \mathrm{~s}$, SC reactions can, ideally, account for all factors that influence the ratio of sorbed to aqueous radionuclide concentrations. Because $\mathrm{SC}$ reactions account for changes in environmental conditions, they provide a much more robust basis for simulating radionuclide migration.

There are many models that describe surface complexation (non-electrostatic, constant capacitance, diffuse layer, triple layer, and others). Unlike the electrostatic models, the non-electrostatic model (NEM, Kurbatov et al., 1951) does not account for surface electrical charge and its effect on sorption. The electrostatic models typically contain one or more parameters that account for surface charge effects. Although the NEM approach over-simplifies the factors affecting surface complexation, several investigators have used this model approach to describe surface complexation (Bradbury and Baeyens, 1997; Davis et al., 1998; Zachara et al., 1994). Davis et al. (1998) argued that the NEM may be the most appropriate for complex environmental applications since the surface charging behavior of non-ideal natural mineral phases is not well known. In this report, this most simplified model is used to quantify radionuclide sorption and simulate radionuclide migration. 


\section{NON-ELECTROSTATIC MODEL DATABASE CONSTRUCTION}

In this report, the sorption of several radionuclides to iron oxides and calcite, are discussed. Published data suggest that these minerals will be significant radionuclide sorbers and that these minerals are often found in alluvial sediments at the Nevada Test Site and many other locations. Several other minerals could also participate in surface complexation reactions; a companion report evaluates radionuclide surface complexation to aluminosilicate minerals (Zavarin and Bruton, 2004). Processes other than surface complexation (ion exchange and precipitation) may also contribute to radionuclide transport but are not discussed in detail here.

The NEM database was developed by fitting NEM reactions to published radionuclide sorption data using the fitting program FITEQL (Herbelin and Westall, 1994). Sorption data were typically retrieved from published figures using the Datathief 1.0.8 program (Huysen and van der Laan, 1992). While fitting NEM reactions to the data, ionic strength, $\mathrm{pH}$, and aqueous complexation were taken into account while electrostatic effects were ignored. The effect of ionic strength on ion activity was accounted for by the Davies equation. Aqueous complexation constants were based on the GEMBOCHS thermodynamic data base version data.com.V8.R6 (Johnson and Lundeen, 1997) with revisions as noted in Pawloski et al. (2001). A summary of these aqueous complexation constants is reported in Appendix C.

All fits to sorption data were accomplished by assuming a single surface site (one-site model). For hydrous ferric oxides, fits to sorption data are more typically accomplished with a two-site model in which weak and strong sorbing sites contribute to total sorption (Dzombak and Morel, 1990). The calcite surface is also thought to have multiple sites (Cowan et al., 1990). A one-site model was used here to limit the number of fitting parameters in our model. The data fit limitations resulting from this simplified approach are discussed in Section 3. During data fitting, the minimum number of surface species necessary to achieve an adequate fit to data was used. In all cases, between one and three surface species were required to fit the data. The adequacy of the model fit was based on a subjective comparison of measured and model predicted sorption. No attempt was made to quantitatively evaluate the adequancy of the model fit.

Radionuclide surface complexation to iron oxides was based on published data for radionuclide sorption to hydrous ferric oxide, goethite, and hematite minerals. Radionuclide surface complexation to the various iron oxide minerals was distinguished only by surface area; it was assumed that surface sites of all iron oxides behave identically. When published data did not include surface areas, $600 \mathrm{~m}^{2} / \mathrm{g}$ was assumed for hydrous ferric oxide and $50 \mathrm{~m}^{2} / \mathrm{g}$ for goethite, as suggested by Turner (1995). For all iron oxide minerals, the site density was assumed to be 2.31 sites $/ \mathrm{nm}^{2}$ (the site density suggested by Dzombak and Morel (1990) for hydrous ferric oxide). In cases where hydrous ferric oxide concentrations were reported as $\mathrm{mol} / \mathrm{L} \mathrm{Fe}$, the site concentration was assumed to be $0.205 \mathrm{~mol}$ sites $/ \mathrm{mol} \mathrm{Fe}$. This site concentration is equal to the sum of strong and weak sites as described in Dzombak and Morel (1990). 
The surface acidity constants for iron oxide minerals $\left(>\mathrm{FeO}^{-}\right.$and $\left.>\mathrm{FeOH}_{2}{ }^{+}\right)$were taken directly from Dzombak and Morel (1990) hydrous ferric oxide diffuse layer model fits. Acidity constants vary depending on both the iron oxide mineral and the SC model (e.g.

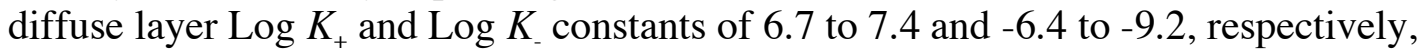
were reported for several iron oxide minerals (Turner, 1995)). For convenience, the diffuse layer hydrous ferric oxide surface acidity constants were used in NEM data fits.

The NEM database constants were often calculated from an average fit to several sorption data sets. ${ }^{3}$ However, fits to certain data sets were omitted from the database average when the quality of sorption data was questionable. In other cases, NEM constants that yielded the most conservative estimate of sorption were included in the database to ensure conservative reactive transport simulation results. The process of data rejection is rather subjective. Nevertheless, justification for data rejection is discussed in the following section.

As in the case of iron oxides, calcite sorption was based on a one-site NEM. When only the surface area was reported, a site density of $10.8 \mathrm{sites} / \mathrm{nm}^{2}$ (or $1.8 \times 10^{-5} \mathrm{~mol} / \mathrm{m}^{2}$ ) was used. This value was suggested by Zachara et al. (1991) from $\mathrm{Ca}$ isotopic exchange measurements. Assuming a $\mathrm{Ca}$ site density equivalent to the density of $\mathrm{Ca}$ positions along the 104 plane, the Ca site density would be $\sim 50 \%$ less than the value reported by Zachara et al. (1991). Sorption may occur within a hydrated calcite surface layer that is several monolayers thick. It is, therefore, possible that the effective number of surface "sorption" sites is greater than the maximum density of surface Ca positions. For 1D reactive transport simulations (Section 5), calcite surface area and site density was taken from a hypothetical aquifer model examined by Zachara et al. (1993) for which surface area was $2.2 \mathrm{~m}^{2} / \mathrm{g}$ and site density was more conservatively estimated at $8.31 \times 10^{-6}$ $\mathrm{mol} / \mathrm{m}^{2}$.

Unlike iron oxide, calcite reactions were written as surface exchange reactions. ${ }^{4}$ This is, in part, due to inadequate study of sorption on slightly soluble minerals such as calcite (as compared to the many numbers of iron oxide sorption studies). Though most calcite sorption studies have assumed that cations sorb by exchange with $\mathrm{Ca}$, it is possible that cations bind directly to exposed $>\mathrm{CO}_{3}$ surface sites. Ignoring electrostatic effects, the two descriptions of sorption to calcite are related. For example, a typical surface complexation reaction and associated equilibrium constant for $\mathrm{Sr}$ (II) sorption to the calcite surface can be described by:

$>\mathrm{CO}_{3}+\mathrm{Sr}^{2+} \Leftrightarrow>\mathrm{CO}_{3} \mathrm{Sr}^{2+} \quad$ and

\footnotetext{
${ }^{3}$ We define a data set as one or more batch sorption experiments performed while varying a single parameter such as $\mathrm{pH}$ or sorber concentration and fit simultaneously using the SC approach. In the literature, when the $\mathrm{pH}$ is varied, the data set is often called a "sorption envelope"; when the sorber concentration is varied, the data set is called a "sorption isotherm".

${ }^{4}$ A surface complexation model of the carbonate mineral-solution interface has been proposed (Van Cappellen et al., 1993) but has not been widely used to model sorption.
} 


$$
K_{\mathrm{Sr}}=\frac{\left(>\mathrm{CO}_{3} \mathrm{Sr}^{2+}\right)}{\left(>\mathrm{CO}_{3}\right)\left(\mathrm{Sr}^{2+}\right)}
$$

Since $\mathrm{Ca}^{2+}$ may also sorb to calcite surfaces, $\mathrm{Ca}^{2+}$ surface complexation to $>\mathrm{CO}_{3}$ sites can be defined by:

$$
\begin{aligned}
& >\mathrm{CO}_{3}+\mathrm{Ca}^{2+} \Leftrightarrow>\mathrm{CO}_{3} \mathrm{Ca}^{2+} \quad \text { and } \\
& K_{\mathrm{Ca}}=\frac{\left(>\mathrm{CO}_{3} \mathrm{Ca}^{2+}\right)}{\left(>\mathrm{CO}_{3}\right)\left(\mathrm{Ca}^{2+}\right)} .
\end{aligned}
$$

The above equations can be combined to describe the surface exchange between $\mathrm{Ca}^{2+}$ and $\mathrm{Sr}^{2+}$ at the calcite surface:

$$
\begin{gathered}
>\mathrm{CO}_{3} \mathrm{Ca}^{2+}+\mathrm{Sr}^{2+} \Leftrightarrow>\mathrm{CO}_{3} \mathrm{Sr}^{2+}+\mathrm{Ca}^{2+} \\
K=K_{\mathrm{Sr}}-K_{\mathrm{Ca}}=\frac{\left(>\mathrm{CO}_{3} \mathrm{Sr}^{2+}\right)\left(\mathrm{Ca}^{2+}\right)}{\left(>\mathrm{CO}_{3} \mathrm{Ca}^{2+}\right)\left(\mathrm{Sr}^{2+}\right)}
\end{gathered}
$$

where the concentration of $>\mathrm{CO}_{3} \mathrm{Ca}^{2+}$ is equal to the isotopically exchangeable $\mathrm{Ca}^{2+}$ surface concentration. ${ }^{5}$ In the NEM database developed in this report, calcite sorption reactions were all developed using a surface exchange model (i.e. Equation 7).

\footnotetext{
${ }^{5} \mathrm{We}$ assume, here, that the concentration of isotopically exchangeable sites (or reactive sites) is constant as a function of solution conditions. This may, in fact, not be the case.
} 


\section{SORPTION DATA FITTING RESULTS}

The following figures and tables comprise the set of data used to derive the average NEM constants summarized in Section 4. Table 1 lists the NEM fits to all data sets collected from the literature (as well as new data reported in Appendices A and B). Figures 1 to 31 present the sorption data along with the model predictions using the average NEM constants. For each set of data, some comments on experimental methods are pertinent; these are presented in the following section. 
Table 1. List of sorption data sets used in this study and their non-electrostatic model reaction constant fits.

\begin{tabular}{|c|c|c|c|c|c|c|c|c|}
\hline Sorption Type & $\begin{array}{c}\text { Element } \\
\text { Conc. } \\
\mathrm{mol} / \mathrm{L}\end{array}$ & $\begin{array}{l}\text { Sorption } \\
\text { Sites }\end{array}$ & $\begin{array}{c}\text { Ionic } \\
\text { Strength }\end{array}$ & $\mathrm{pCO}_{2}$ & Species & $\log K$ & Comments & Refs \\
\hline \multirow{22}{*}{$\begin{array}{l}\mathrm{Am}(\mathrm{III}) \text { on } \mathrm{Fe}_{2} \mathrm{O}_{3} \\
\text { colloids }\end{array}$} & $8 \mathrm{E}-9$ & $1.82 \mathrm{E}-6$ & 0.001 & $5 \mathrm{E}-5$ & $>\mathrm{FeOAm}^{2+}$ & 0.82 & curve & 19 \\
\hline & & & & & $>\mathrm{FeOAm}(\mathrm{OH})_{2}$ & -15.3 & & \\
\hline & $8 \mathrm{E}-9$ & $1.82 \mathrm{E}-6$ & 0.01 & $5 \mathrm{E}-5$ & $>\mathrm{FeOAm}^{2+}$ & 0.96 & curve & 19 \\
\hline & & & & & $>\mathrm{FeOAm}(\mathrm{OH})_{2}$ & -15.6 & & \\
\hline & $8 E-9$ & $1.82 \mathrm{E}-6$ & 0.1 & $5 \mathrm{E}-5$ & $>\mathrm{FeOAm}^{2+}$ & 1.25 & curve & 19 \\
\hline & & & & & $>\mathrm{FeOAm}(\mathrm{OH})_{2}$ & -15.5 & & \\
\hline & $8 \mathrm{E}-9$ & $1.82 \mathrm{E}-6$ & 1 & $5 \mathrm{E}-5$ & $>\mathrm{FeOAm}^{2+}$ & 1.81 & curve & 19 \\
\hline & & & & & $>\mathrm{FeOAm}(\mathrm{OH})_{2}$ & -14.9 & & \\
\hline & $8 \mathrm{E}-9$ & $9.11 \mathrm{E}-7$ & 0.1 & $5 \mathrm{E}-5$ & $>\mathrm{FeOAm}^{2+}$ & 0.51 & curve & 19 \\
\hline & & & & & $>\mathrm{FeOAm}(\mathrm{OH})_{2}$ & -15.6 & & \\
\hline & $8 \mathrm{E}-9$ & $1.82 \mathrm{E}-6$ & 0.1 & $5 \mathrm{E}-5$ & $>\mathrm{FeOAm}^{2+}$ & 1.22 & curve & 19 \\
\hline & & & & & $>\mathrm{FeOAm}(\mathrm{OH})_{2}$ & -15.5 & & \\
\hline & $8 \mathrm{E}-9$ & $9.11 \mathrm{E}-6$ & 0.1 & $5 \mathrm{E}-5$ & $>\mathrm{FeOAm}^{2+}$ & 2.02 & curve & 19 \\
\hline & & & & & $>\mathrm{FeOAm}(\mathrm{OH})_{2}$ & -14.7 & & \\
\hline & $1.5 \mathrm{E}-9$ & $1.82 \mathrm{E}-6$ & 0.1 & $5 \mathrm{E}-5$ & $>\mathrm{FeOAm}^{2+}$ & 1.41 & curve & 19 \\
\hline & & & & & $>\mathrm{FeOAm}(\mathrm{OH})_{2}$ & -15.3 & & \\
\hline & $8 \mathrm{E}-9$ & $1.82 \mathrm{E}-6$ & 0.1 & $5 \mathrm{E}-5$ & $>\mathrm{FeOAm}^{2+}$ & 1.03 & curve & 19 \\
\hline & & & & & $>\mathrm{FeOAm}(\mathrm{OH})_{2}$ & -15.5 & & \\
\hline & $8 \mathrm{E}-9$ & $9.11 \mathrm{E}-6$ & 0.1 & $5 \mathrm{E}-5$ & $>\mathrm{FeOAm}^{2+}$ & 1.23 & curve & 19 \\
\hline & & & & & $>\mathrm{FeOAm}(\mathrm{OH})_{2}$ & -15.6 & & \\
\hline & $8 \mathrm{E}-9$ & $3.07 \mathrm{E}-6$ & 0.1 & $5 \mathrm{E}-5$ & $>\mathrm{FeOAm}^{2+}$ & 1.42 & curve & 19 \\
\hline & & & & & $>\mathrm{FeOAm}(\mathrm{OH})_{2}$ & -14.7 & & \\
\hline \multirow[t]{10}{*}{ Am(III) on calcite } & $7 \mathrm{E}-9$ & $5 \mathrm{E}-5$ & S.W. & 3.5 & $>\mathrm{AmCO}_{3}^{+}$ & 4.16 & 1 pt., $\mathrm{pH} \sim 8$ & 1 \\
\hline & $1.4 \mathrm{E}-8$ & $5 \mathrm{E}-5$ & S.W. & 3.5 & $>\mathrm{AmCO}_{3}^{+}$ & 4.09 & 1 pt., $\mathrm{pH} \sim 8$ & 1 \\
\hline & $2.1 \mathrm{E}-8$ & $5 \mathrm{E}-5$ & S.W. & 3.5 & $>\mathrm{AmCO}_{3}^{+}$ & 4.12 & 1 pt., $\mathrm{pH} \sim 8$ & 1 \\
\hline & $2.8 \mathrm{E}-8$ & $5 \mathrm{E}-5$ & S.W. & 3.5 & $>\mathrm{AmCO}_{3}^{+}$ & 4.09 & 1 pt., $\mathrm{pH} \sim 8$ & 1 \\
\hline & $3.5 \mathrm{E}-8$ & $5 \mathrm{E}-5$ & S.W. & 3.5 & $>\mathrm{AmCO}_{3}^{+}$ & 4.07 & 1 pt., $\mathrm{pH} \sim 8$ & 1 \\
\hline & $4.2 \mathrm{E}-8$ & $5 \mathrm{E}-5$ & S.W. & 3.5 & $>\mathrm{AmCO}_{3}^{+}$ & 4.05 & 1 pt., $\mathrm{pH} \sim 8$ & 1 \\
\hline & $4.9 \mathrm{E}-8$ & $5 \mathrm{E}-5$ & S.W. & 3.5 & $>\mathrm{AmCO}_{3}^{+}$ & 4.1 & 1 pt., $\mathrm{pH} \sim 8$ & 1 \\
\hline & $5.6 \mathrm{E}-8$ & $5 \mathrm{E}-5$ & S.W. & 3.5 & $>\mathrm{AmCO}_{3}^{+}$ & 4.13 & 1 pt., $\mathrm{pH} \sim 8$ & 1 \\
\hline & $6.3 \mathrm{E}-8$ & $5 \mathrm{E}-5$ & S.W. & 3.5 & $>\mathrm{AmCO}_{3}^{+}$ & 4.21 & 1 pt., $\mathrm{pH} \sim 8$ & 1 \\
\hline & $7 \mathrm{E}-8$ & $5 \mathrm{E}-5$ & S.W. & 3.5 & $>\mathrm{AmCO}_{3}^{+}$ & 4.26 & 1 pt., $\mathrm{pH} \sim 8$ & 1 \\
\hline $\mathrm{Eu}(\mathrm{III})$ on $\mathrm{FeOOH}$ & $1 \mathrm{E}-8$ & $6 \mathrm{E}-5$ & 0.01 & $5 \mathrm{E}-5$ & $>\mathrm{FeOEu}^{2+}$ & 1.36 & curve & 2 \\
\hline $\mathrm{Eu}(\mathrm{III})$ on $\mathrm{Fe}(\mathrm{OH})_{3}$ & $1 \mathrm{E}-8$ & $6.1 \mathrm{E}-5$ & 0.01 & $5 \mathrm{E}-5$ & $>\mathrm{FeOEu}^{2+}$ & 2.62 & curve & 2 \\
\hline $\mathrm{Eu}(\mathrm{III})$ on $\mathrm{Fe}_{2} \mathrm{O}_{3}$ & $1 \mathrm{E}-8$ & $8.3 \mathrm{E}-5$ & 0.01 & $5 \mathrm{E}-5$ & $>\mathrm{FeOEu}^{2+}$ & 1.61 & curve & 2 \\
\hline \multirow[t]{4}{*}{$\mathrm{Eu}(\mathrm{III})$ on $\mathrm{FeOOH}$} & $1 \mathrm{E}-5$ & $2.3 \mathrm{E}-5$ & 0.01 & 0.005 & $>\mathrm{FeOEu}^{2+}$ & 0.59 & curve & 16 \\
\hline & & & & & $>\mathrm{FeOEu}(\mathrm{OH})_{2}$ & -11.5 & & \\
\hline & & & & $5 \mathrm{E}-5$ & $>\mathrm{FeOEu}^{2+}$ & -0.4 & curve & 16 \\
\hline & & & & & $>\mathrm{FeOEu}(\mathrm{OH})_{2}$ & -13.77 & & \\
\hline
\end{tabular}


Table 1. Continued.

\begin{tabular}{|c|c|c|c|c|c|c|c|c|}
\hline Sorption Type & $\begin{array}{c}\text { Element } \\
\text { Conc. } \\
\mathrm{mol} / \mathrm{L}\end{array}$ & $\begin{array}{c}\text { Sorption } \\
\text { Sites }\end{array}$ & $\begin{array}{c}\text { Ionic } \\
\text { Strength }\end{array}$ & $\mathrm{pCO}_{2}$ & Species & $\log K$ & Comments & Refs \\
\hline \multirow[t]{8}{*}{$\mathrm{Eu}(\mathrm{III})$ on $\mathrm{Fe}_{2} \mathrm{O}_{3}$} & $1.79 \mathrm{E}-5$ & $1 \mathrm{E}-4$ & 0.1 & none & $>\mathrm{FeOEu}^{2+}$ & 0.71 & curve & 17 \\
\hline & & & & & $>\mathrm{FeOEu}(\mathrm{OH})_{2}$ & $\sim-15$ & & \\
\hline & $1.79 \mathrm{E}-6$ & $1 \mathrm{E}-4$ & 0.1 & none & $>\mathrm{FeOEu}^{2+}$ & 3.18 & curve & 17 \\
\hline & & & & & $>\mathrm{FeOEu}(\mathrm{OH})_{2}$ & -16.07 & & \\
\hline & & & & & $>\mathrm{FeOEu}^{2+}$ & 3.79 & pH4 isotherm & 17 \\
\hline & & & & & $>\mathrm{FeOEu}^{2+}$ & 2.4 & $\mathrm{pH} 5$ isotherm & 17 \\
\hline & & & & & $>\mathrm{FeOEu}^{2+}$ & 1.72 & $\mathrm{pH} 5.5$ isotherm & 17 \\
\hline & & & & & $>\mathrm{FeOEu}^{2+}$ & 0.69 & $\mathrm{pH} 6$ isotherm & 17 \\
\hline \multirow[t]{3}{*}{$\mathrm{Eu}(\mathrm{III})$ on calcite } & $7 \mathrm{E}-8$ & caprice & S.W. & 3.5 & $\mathrm{EuCO}_{3}$ & 2.57 & 1 pt., $\mathrm{pH} \sim 8$ & 3 \\
\hline & $6.5 \mathrm{E}-7$ & $3.3 \mathrm{E}-6$ & S.W. & 3.5 & $>\mathrm{EuCO}_{3}^{+}$ & 3.09 & 1 pt., $\mathrm{pH} \sim 8$ & 3 \\
\hline & & & & 3.5 & $>\mathrm{EuCO}_{3}^{+}$ & 4.14 & curve & 20 \\
\hline \multirow[t]{12}{*}{$\mathrm{Np}(\mathrm{V})$ on $\mathrm{Fe}(\mathrm{OH})_{3}$} & $4.5 \mathrm{E}-13$ & $2.1 \mathrm{E}-3$ & 0.1 & $5 \mathrm{E}-5 \dagger$ & $>\mathrm{FeOHNpO}_{2}^{+}$ & 4.22 & curve & 4 \\
\hline & & & & & $>\mathrm{FeOHNpO}_{3}^{-}$ & -8.17 & & \\
\hline & 4.7E-12 & $2.1 \mathrm{E}-3$ & 0.1 & $5 \mathrm{E}-5 \dagger$ & $>\mathrm{FeOHNpO}_{2}^{+}$ & 4.27 & curve & 4 \\
\hline & & & & & $>\mathrm{FeOHNpO}_{3}^{-}$ & -9.07 & & \\
\hline & $4.5 \mathrm{E}-11$ & $2.1 \mathrm{E}-3$ & 0.1 & $5 \mathrm{E}-5 \dagger$ & $>\mathrm{FeOHNpO}_{2}^{+}$ & 4.27 & curve & 4 \\
\hline & & & & & $>\mathrm{FeOHNpO}_{3}^{-}$ & -9.38 & & \\
\hline & $4.7 \mathrm{E}-12$ & $2.1 \mathrm{E}-3$ & 0.1 & $5 \mathrm{E}-5 \dagger$ & $>\mathrm{FeOHNpO}_{2}^{+}$ & 4.35 & curve & 4 \\
\hline & & & & & $>\mathrm{FeOHNpO}_{3}^{-}$ & -10.19 & & \\
\hline & 4.7E-12 & $7.6 \mathrm{E}-4$ & 0.1 & $5 \mathrm{E}-5 \dagger$ & $>\mathrm{FeOHNpO}_{2}^{+}$ & 4.46 & curve & 4 \\
\hline & & & & & $>\mathrm{FeOHNpO}_{3}^{-}$ & -11.01 & & \\
\hline & 4.7E-12 & $2.1 \mathrm{E}-4$ & 0.1 & $5 E-5 \dagger$ & $>\mathrm{FeOHNpO}_{2}^{+}$ & 4.47 & curve & 4 \\
\hline & & & & & $>\mathrm{FeOHNpO}_{3}^{-}$ & -11.26 & & \\
\hline \multirow[t]{4}{*}{$\mathrm{Np}(\mathrm{V})$ on $\mathrm{FeOOH}$} & $6 \mathrm{E}-6$ & $1.4 \mathrm{E}-4$ & 0.1 & $5 \mathrm{E}-5 \dagger$ & $>\mathrm{FeOHNpO}_{2}^{+}$ & 3.86 & curve & 5 \\
\hline & & & & & $>\mathrm{FeOHNpO}_{3}^{-}$ & -12.95 & & \\
\hline & $6 \mathrm{E}-6$ & $1.4 \mathrm{E}-4$ & 0.1 & 3.5 & $>\mathrm{FeOHNpO}_{2}^{+}$ & 3.54 & curve & 5 \\
\hline & & & & & $>\mathrm{FeOHNpO}_{3}^{-}$ & 10.84 & & \\
\hline $\mathrm{Np}(\mathrm{V})$ on natural & $6 \mathrm{E}-6$ & $6 \mathrm{E}-5$ & 0.1 & $5 \mathrm{E}-5 \dagger$ & $>\mathrm{FeOHNpO}_{2}^{+}$ & 4.66 & curve & 5 \\
\hline \multirow[t]{3}{*}{$\mathrm{FeOOH}$} & & & & & $>\mathrm{FeOHNpO}_{3}^{-}$ & -12.89 & & \\
\hline & $6 \mathrm{E}-6$ & $6 \mathrm{E}-5$ & 0.1 & 3.5 & $>\mathrm{FeOHNpO}_{2}^{+}$ & 4.61 & curve & 5 \\
\hline & & & & & $>\mathrm{FeOHNpO}_{3}^{-}$ & -10.89 & & \\
\hline \multirow[t]{9}{*}{$\mathrm{Np}(\mathrm{V})$ on calcite } & $1 \mathrm{E}-14$ & $9 \mathrm{E}-5$ & D.I. & 3.5 & $>\mathrm{NpO}_{2}^{+}$ & 2.50 & 1 pt., $\mathrm{pH} \sim 8$ & 6 \\
\hline & $1 \mathrm{E}-14$ & $9 \mathrm{E}-5$ & S.W. & 3.5 & $>\mathrm{NpO}_{2}^{+}$ & 2.12 & 1 pt., $\mathrm{pH} \sim 8$ & 6 \\
\hline & $3.9 \mathrm{E}-15$ & $9 \mathrm{E}-5$ & D.I. & 3.5 & $>\mathrm{NpO}_{2}^{+}$ & 2.61 & 1 pt., $\mathrm{pH} \sim 8$ & 6 \\
\hline & $4.6 \mathrm{E}-13$ & $9 \mathrm{E}-5$ & D.I. & 3.5 & $>\mathrm{NpO}_{2}{ }^{+}$ & 2.51 & 1 pt., $\mathrm{pH} \sim 8$ & 6 \\
\hline & 4.3E-11 & $9 \mathrm{E}-5$ & D.I. & 3.5 & $>\mathrm{NpO}_{2}{ }^{+}$ & 2.45 & 1 pt., $\mathrm{pH} \sim 8$ & 6 \\
\hline & $1.6 \mathrm{E}-14$ & $9 \mathrm{E}-5$ & S.W. & 3.5 & $>\mathrm{NpO}_{2}{ }^{+}$ & 2.19 & 1 pt., $\mathrm{pH} \sim 8$ & 6 \\
\hline & $1.6 \mathrm{E}-12$ & $9 \mathrm{E}-5$ & S.W. & 3.5 & $>\mathrm{NpO}_{2}{ }^{+}$ & 2.19 & 1 pt., $\mathrm{pH} \sim 8$ & 6 \\
\hline & $1.7 \mathrm{E}-10$ & $9 \mathrm{E}-5$ & S.W. & 3.5 & $>\mathrm{NpO}_{2}{ }^{+}$ & 2.20 & 1 pt., $\mathrm{pH} \sim 8$ & 6 \\
\hline & & & & 3.5 & $>\mathrm{NpO}_{2}^{+}$ & 1.46 & curve & 20 \\
\hline
\end{tabular}

(continued) 
Table 1. Continued.

\begin{tabular}{|c|c|c|c|c|c|c|c|c|}
\hline Sorption Type & $\begin{array}{c}\text { Element } \\
\text { Conc. } \\
\mathrm{mol} / \mathrm{L}\end{array}$ & $\begin{array}{c}\text { Sorption } \\
\text { Sites }\end{array}$ & $\begin{array}{c}\text { Ionic } \\
\text { Strength }\end{array}$ & $\mathrm{pCO}_{2}$ & Species & $\log K$ & Comments & Refs \\
\hline \multirow[t]{4}{*}{$\mathrm{Pu}(\mathrm{IV})$ on $\mathrm{FeOOH}$} & $1 \mathrm{E}-10$ & $1.1 \mathrm{E}-4$ & 0.1 & $0 \dagger$ & $>\mathrm{FeOHPuO}^{2+}$ & 6.83 & curve & 7 \\
\hline & & & & & $>\mathrm{FeOPuO}_{2}$ & -1.59 & & \\
\hline & $1 \mathrm{E}-11$ & $1.1 \mathrm{E}-4$ & 0.1 & $0 \dagger$ & $>\mathrm{FeOHPuO}^{2+}$ & 7.03 & curve & 7 \\
\hline & & & & & $>\mathrm{FeOPuO}_{2}$ & -1.00 & & \\
\hline \multirow[t]{4}{*}{$\mathrm{Pu}(\mathrm{V})$ on $\mathrm{FeOOH}$} & $1 \mathrm{E}-10$ & $1.1 \mathrm{E}-4$ & 0.1 & $0 \dagger$ & $>\mathrm{FeOHPuO}_{2}^{+}$ & 4.99 & curve & 7 \\
\hline & & & & & $>\mathrm{FeOHPuO}_{3}^{-}$ & -10.68 & & \\
\hline & $1 \mathrm{E}-11$ & $1.1 \mathrm{E}-4$ & 0.1 & $0 \dagger$ & $>\mathrm{FeOHPuO}_{2}^{+}$ & 4.60 & curve & 7 \\
\hline & & & & & $>\mathrm{FeOHPuO}_{3}^{-}$ & -10.63 & & \\
\hline $\mathrm{Pu}(\mathrm{IV})$ on calcite & $5 \mathrm{E}-9$ & $1.1 \mathrm{E}-5$ & 0.1 & 3.5 & $>\mathrm{Pu}(\mathrm{OH})_{3}{ }^{+}$ & 7.23 & curve & 21 \\
\hline \multirow[t]{8}{*}{$\mathrm{Pu}(\mathrm{V})$ on calcite } & $\sim 1 \mathrm{E}-11$ & & S.W & 3.5 & $>\mathrm{PuO}_{2}^{+}$ & 2.24 & 1 pt., $\mathrm{pH} \sim 8$ & 8 \\
\hline & $\sim 1 \mathrm{E}-11$ & & D.I. & 3.5 & $>\mathrm{PuO}_{2}^{+}$ & 2.02 & 1 pt., $\mathrm{pH} \sim 8$ & 8 \\
\hline & $\sim 1 \mathrm{E}-11$ & & S.W & 3.5 & $>\mathrm{PuO}_{2}^{+}$ & 1.39 & 1 pt., $\mathrm{pH} \sim 8$ & 8 \\
\hline & $\sim 1 \mathrm{E}-11$ & & D.I. & 3.5 & $>\mathrm{PuO}_{2}^{+}$ & 2.03 & 1 pt., $\mathrm{pH} \sim 8$ & 8 \\
\hline & $\sim 1 \mathrm{E}-11$ & & S.W. & 3.5 & $>\mathrm{PuO}_{2}^{+}$ & 1.32 & 1 pt., $\mathrm{pH} \sim 8$ & 8 \\
\hline & $\sim 1 \mathrm{E}-11$ & & D.I. & 3.5 & $>\mathrm{PuO}_{2}^{+}$ & 1.99 & 1 pt., $\mathrm{pH} \sim 8$ & 8 \\
\hline & $\sim 1 \mathrm{E}-11$ & & 0.7 & 3.5 & $>\mathrm{PuO}_{2}^{+}$ & 1.98 & 1 pt., $\mathrm{pH} \sim 8$ & 8 \\
\hline & $1 \mathrm{E}-7$ & $1.1 \mathrm{E}-5$ & 0.1 & 3.5 & $>\mathrm{PuO}_{2}^{+}$ & 1.63 & curve & 21 \\
\hline \multirow[t]{3}{*}{ Sm(III) on calcite } & $7 \mathrm{E}-8$ & coprecip & S.W. & 3.5 & $\mathrm{SmCO}_{3}$ & 2.53 & 1 pt., $\mathrm{pH} \sim 8$ & 3 \\
\hline & $6.5 \mathrm{E}-7$ & $3.3 \mathrm{E}-6$ & S.W. & 3.5 & $>\mathrm{SmCO}_{3}^{+}$ & 3.03 & 1 pt., $\mathrm{pH} \sim 8$ & \\
\hline & & & 0.1 & 3.5 & $>\mathrm{SmCO}_{3}^{+}$ & 4.62 & curve & 20 \\
\hline \multirow[t]{3}{*}{$\mathrm{Sr}(\mathrm{II})$ on $\mathrm{Fe}(\mathrm{OH})_{3}$} & $2 \mathrm{E}-6$ & $1.9 \mathrm{E}-2$ & 1 & 3.5 & $>\mathrm{FeOHSr}^{2+}$ & 2.16 & curve & 9 \\
\hline & & & & & $>\mathrm{FeOSr}^{+}$ & -5.20 & & \\
\hline & & & & & $>\mathrm{FeOSrOH}$ & -14.02 & & \\
\hline \multirow[t]{18}{*}{$\mathrm{Sr}(\mathrm{II})$ on $\mathrm{Fe}(\mathrm{OH})_{3}$} & $1.0 \mathrm{E}-7$ & $2.05 \mathrm{E}-2$ & 1 & $5 \mathrm{E}-5$ & $>\mathrm{FeOHSr}^{2+}$ & 2.29 & curve & 18 \\
\hline & & & & & $>\mathrm{FeOSr}^{+}$ & -4.96 & & \\
\hline & & & & & $>\mathrm{FeOSrOH}$ & -14.60 & & \\
\hline & $8.3 \mathrm{E}-6$ & $2.05 \mathrm{E}-2$ & 1 & $5 \mathrm{E}-5$ & $>\mathrm{FeOHSr}^{2+}$ & 2.44 & curve & 18 \\
\hline & & & & & $>\mathrm{FeOSr}^{+}$ & -5.37 & & \\
\hline & & & & & $>\mathrm{FeOSrOH}$ & -13.40 & & \\
\hline & $8.3 \mathrm{E}-5$ & $2.05 \mathrm{E}-2$ & 1 & $5 \mathrm{E}-5$ & $>\mathrm{FeOHSr}^{2+}$ & 2.27 & curve & 18 \\
\hline & & & & & $>\mathrm{FeOSr}^{+}$ & -5.47 & & \\
\hline & & & & & $>\mathrm{FeOSrOH}$ & -14.02 & & \\
\hline & $1 \mathrm{E}-3$ & $2.05 \mathrm{E}-2$ & 1 & $5 \mathrm{E}-5$ & $>\mathrm{FeOHSr}^{2+}$ & 1.96 & curve & 18 \\
\hline & & & & & $>\mathrm{FeOSr}^{+}$ & -5.96 & & \\
\hline & & & & & $>\mathrm{FeOSrOH}$ & -14.80 & & \\
\hline & $5 \mathrm{E}-3$ & $2.05 \mathrm{E}-2$ & 1 & $5 \mathrm{E}-5$ & $>\mathrm{FeOHSr}^{2+}$ & 1.68 & curve & 18 \\
\hline & & & & & $>\mathrm{FeOSr}^{+}$ & -6.30 & & \\
\hline & & & & & $>\mathrm{FeOSrOH}$ & -16.00 & & \\
\hline & $1 \mathrm{E}-2$ & $2.05 \mathrm{E}-2$ & 1 & $5 \mathrm{E}-5$ & $>\mathrm{FeOHSr}^{2+}$ & 1.48 & curve & 18 \\
\hline & & & & & $>\mathrm{FeOSr}^{+}$ & -6.55 & & \\
\hline & & & & & $>\mathrm{FeOSrOH}$ & -16.60 & & \\
\hline
\end{tabular}


Table 1. Continued.

\begin{tabular}{|c|c|c|c|c|c|c|c|c|}
\hline Sorption Type & $\begin{array}{l}\text { Element } \\
\text { Conc. } \\
\mathrm{mol} / \mathrm{L}\end{array}$ & $\begin{array}{l}\text { Sorption } \\
\text { Sites }\end{array}$ & $\begin{array}{c}\text { Ionic } \\
\text { Strength }\end{array}$ & $\mathrm{pCO}_{2}$ & Species & $\log K$ & Comments & Refs \\
\hline \multirow[t]{15}{*}{$\mathrm{Sr}(\mathrm{II})$ on $\mathrm{Fe}(\mathrm{OH})_{3}$} & $5 \mathrm{E}-2$ & $2.05 \mathrm{E}-2$ & 1 & $5 \mathrm{E}-5$ & $>\mathrm{FeOHSr}^{2+}$ & 1.09 & curve & 18 \\
\hline & & & & & $>\mathrm{FeOSr}^{+}$ & -7.13 & & \\
\hline & & & & & $>\mathrm{FeOSrOH}$ & -17.90 & & \\
\hline & $1 \mathrm{E}-7$ & $4.1 \mathrm{E}-3$ & 1 & $5 \mathrm{E}-5$ & $>\mathrm{FeOHSr}^{2+}$ & 2.20 & curve & 18 \\
\hline & & & & & $>\mathrm{FeOSr}^{+}$ & -5.36 & & \\
\hline & & & & & $>\mathrm{FeOSrOH}$ & -14.22 & & \\
\hline & $1 \mathrm{E}-7$ & $1.03 \mathrm{E}-2$ & 1 & $5 \mathrm{E}-5$ & $>\mathrm{FeOHSr}^{2+}$ & 2.27 & curve & 18 \\
\hline & & & & & $>\mathrm{FeOSr}^{+}$ & -5.32 & & \\
\hline & & & & & $>\mathrm{FeOSrOH}$ & -14.00 & & \\
\hline & $1 \mathrm{E}-7$ & $2.05 \mathrm{E}-2$ & 1 & $5 \mathrm{E}-5$ & $>\mathrm{FeOHSr}^{2+}$ & 2.28 & curve & 18 \\
\hline & & & & & $>\mathrm{FeOSr}^{+}$ & -4.95 & & \\
\hline & & & & & $>\mathrm{FeOSrOH}$ & -14.20 & & \\
\hline & $1 \mathrm{E}-7$ & 4.1E-2 & 1 & $5 \mathrm{E}-5$ & $>\mathrm{FeOHSr}^{2+}$ & 2.14 & curve & 18 \\
\hline & & & & & $>\mathrm{FeOSr}^{+}$ & -5.08 & & \\
\hline & & & & & $>\mathrm{FeOSrOH}$ & -14.02 & & \\
\hline $\operatorname{Sr}(\mathrm{II})$ on calcite & $1.0 \mathrm{E}-7$ & $9 \mathrm{E}-5$ & 0.1 & 3.5 & $>\mathrm{Sr}^{2+}$ & -1.75 & curve & 10 \\
\hline \multirow[t]{6}{*}{$\mathrm{U}(\mathrm{VI})$ on $\mathrm{FeOOH}$} & $8.4 \mathrm{E}-6$ & $1.8 \mathrm{E}-3$ & 0.1 & 2.66 & $>\mathrm{FeOHUO}_{3}$ & -2.65 & curve & 11 \\
\hline & & & & & $>\mathrm{FeOHUO}_{2}{ }^{2+}$ & 6.58 & & \\
\hline & $8.4 \mathrm{E}-6$ & $1.8 \mathrm{E}-3$ & 0.1 & 1.3 & $>\mathrm{FeOHUO}_{3}$ & -2.70 & curve & 11 \\
\hline & & & & & $>\mathrm{FeOHUO}_{2}{ }^{2+}$ & 6.58 & & \\
\hline & $8.4 \mathrm{E}-6$ & $1.8 \mathrm{E}-3$ & 0.1 & 0.037 & $>\mathrm{FeOHUO}_{3}$ & -3.76 & curve & 11 \\
\hline & & & & & $>\mathrm{FeOHUO}_{2}{ }^{2+}$ & 7.40 & & \\
\hline \multirow[t]{2}{*}{$\mathrm{U}(\mathrm{VI})$ on $\mathrm{Fe}_{2} \mathrm{O}_{3}$} & $2.0 \mathrm{E}-6$ & $5.8 \mathrm{E}-6$ & 0.01 & $0 \dagger$ & $>\mathrm{FeOHUO}_{3}$ & -2.41 & curve & 12 \\
\hline & & & & & $>\mathrm{FeOHUO}_{2}{ }^{2+}$ & 7.56 & & \\
\hline \multirow[t]{4}{*}{$\mathrm{U}(\mathrm{VI})$ on $\mathrm{FeOOH}$} & $1 \mathrm{E}-5$ & $1.9 \mathrm{E}-4$ & 0.1 & $1 \mathrm{E}-3 \dagger$ & $>\mathrm{FeOHUO}_{3}$ & -2.49 & curve & 13 \\
\hline & & & & & $>\mathrm{FeOHUO}_{2}{ }^{2+}$ & 6.93 & & \\
\hline & $1 \mathrm{E}-5$ & $1.9 \mathrm{E}-4$ & 0.1 & $1 \mathrm{E}-2 \dagger$ & $>\mathrm{FeOHUO}_{3}$ & -2.13 & curve & 13 \\
\hline & & & & & $>\mathrm{FeOHUO}_{2}{ }^{2+}$ & 7.25 & & \\
\hline \multirow[t]{2}{*}{$\mathrm{U}(\mathrm{VI})$ on $\mathrm{Fe}(\mathrm{OH})_{3}$} & $1 \mathrm{E}-5$ & $2.3 \mathrm{E}-3$ & 0.1 & $0 \dagger$ & $>\mathrm{FeOHUO}_{3}$ & -3.07 & curve & 13 \\
\hline & & & & & $>\mathrm{FeOHUO}_{2}{ }^{2+}$ & 6.53 & & \\
\hline \multirow[t]{2}{*}{$\mathrm{U}(\mathrm{VI})$ on $\mathrm{FeOOH}$} & $1 \mathrm{E}-5$ & $1.9 \mathrm{E}-4$ & 0.1 & $0 \dagger$ & $>\mathrm{FeOHUO}_{3}$ & -2.63 & curve & 13 \\
\hline & & & & & $>\mathrm{FeOHUO}_{2}{ }^{2+}$ & 7.12 & & \\
\hline \multirow[t]{2}{*}{$\mathrm{U}(\mathrm{VI})$ on syn. $\mathrm{Fe}_{2} \mathrm{O}_{3}$} & $1 \mathrm{E}-5$ & $1.2 \mathrm{E}-5$ & 0.1 & $0 \dagger$ & $>\mathrm{FeOHUO}_{3}$ & -3.19 & curve & 13 \\
\hline & & & & & $>\mathrm{FeOHUO}_{2}{ }^{2+}$ & 7.40 & & \\
\hline \multirow[t]{2}{*}{$\mathrm{U}(\mathrm{VI})$ on nat. $\mathrm{Fe}_{2} \mathrm{O}_{3}$} & $1 \mathrm{E}-5$ & $6.9 \mathrm{E}-6$ & 0.1 & $0 \dagger$ & $>\mathrm{FeOHUO}_{3}$ & -3.22 & curve & 13 \\
\hline & & & & & $>\mathrm{FeOHUO}_{2}{ }^{2+}$ & 6.58 & & \\
\hline
\end{tabular}

(continued) 
Table 1. Continued.

\begin{tabular}{|c|c|c|c|c|c|c|c|c|}
\hline Sorption Type & $\begin{array}{c}\text { Element } \\
\text { Conc. } \\
\mathrm{mol} / \mathrm{L}\end{array}$ & $\begin{array}{c}\text { Sorption } \\
\text { Sites }\end{array}$ & $\begin{array}{c}\text { Ionic } \\
\text { Strength }\end{array}$ & $\overline{\mathrm{pCO}_{2}}$ & Species & $\log K$ & Comments & Refs \\
\hline \multirow[t]{14}{*}{$\mathrm{U}(\mathrm{VI})$ on $\mathrm{Fe}(\mathrm{OH})_{3}$} & $1 \mathrm{E}-6$ & $2.1 \mathrm{E}-4$ & 0.02 & 3.5 & $>\mathrm{FeOHUO}_{3}$ & -2.97 & curve & 14 \\
\hline & & & & & $>\mathrm{FeOHUO}_{2}{ }^{2+}$ & 6.42 & & \\
\hline & $1 \mathrm{E}-6$ & $2.1 \mathrm{E}-4$ & 0.5 & 3.5 & $>\mathrm{FeOHUO}_{3}$ & -3.57 & curve & 14 \\
\hline & & & & & $>\mathrm{FeOHUO}_{2}{ }^{2+}$ & 6.72 & & \\
\hline & $1 \mathrm{E}-6$ & 4.1E-3 & 0.1 & 3.5 & $>\mathrm{FeOHUO}_{3}$ & -1.70 & curve & 14 \\
\hline & & & & & $>\mathrm{FeOHUO}_{2}{ }^{2+}$ & 5.48 & & \\
\hline & $1 \mathrm{E}-6$ & $2.1 \mathrm{E}-4$ & 0.1 & 3.5 & $>\mathrm{FeOHUO}_{3}$ & -3.13 & curve & 14 \\
\hline & & & & & $>\mathrm{FeOHUO}_{2}{ }^{2+}$ & 6.58 & & \\
\hline & $1 \mathrm{E}-5$ & $2.1 \mathrm{E}-4$ & 0.1 & 3.5 & $>\mathrm{FeOHUO}_{3}$ & -3.76 & curve & 14 \\
\hline & & & & & $>\mathrm{FeOHUO}_{2}{ }^{2+}$ & 6.35 & & \\
\hline & $1 \mathrm{E}-8$ & $2.1 \mathrm{E}-4$ & 0.1 & 3.5 & $>\mathrm{FeOHUO}_{3}$ & -2.57 & curve & 14 \\
\hline & & & & & $>\mathrm{FeOHUO}_{2}{ }^{2+}$ & 6.81 & & \\
\hline & $1 \mathrm{E}-6$ & $2.1 \mathrm{E}-4$ & 0.1 & 2 & $>\mathrm{FeOHUO}_{3}$ & -3.06 & curve & 14 \\
\hline & & & & & $>\mathrm{FeOHUO}_{2}{ }^{2+}$ & 6.74 & & \\
\hline $\mathrm{U}(\mathrm{VI})$ on calcite & $\begin{array}{c}1 \mathrm{E}-5 \text { to } \\
1 \mathrm{E}-2\end{array}$ & --- & 0.005 & $2-3$ & $>\mathrm{UO}_{2}$ & 5.12 & curve & 15 \\
\hline
\end{tabular}

$\uparrow \mathrm{CO}_{2}$ concentration measured as total carbonate $(\mathrm{mol} / \mathrm{L})$

REFERENCES: 1. (Shanbhag and Morse, 1982); 2. (Ledin et al., 1994); 3. (Zhong and Mucci, 1995$) ; 4$. (Girvin et al., 1991); 5. (Nakayama and Sakamoto, 1991); 6. (Keeney-Kennicutt and Morse, 1984); 7. (Sanchez et al., 1985); 8. (Keeney-Kennicutt and Morse, 1985); 9. (Kinniburgh et al., 1975); 10. (Zachara et al., 1991); 11. (Duff and Amrhein, 1996); 12. (Viani and Torretto, 1998); 13. (Hsi and Langmuir, 1985); 14. (Waite et al., 1994); 15. (Carroll and Bruno, 1991); 16. (Fujita and Tsukamoto, 1997); 17. (Rabung et al., 1998); 18. (Kolarik, 1961); 19. (Cromiere, 1996); 20. Appendix A; 21. Appendix B. 


\subsection{Am(III) on Iron Oxide Minerals}

Am(III) sorption experiments of Cromieres (1996) consisted of 11 sets of batch sorption experiments. Each set of batch sorption experiments was performed over a wide range of $\mathrm{pH}$, under relatively constant carbonate alkalinity $\left(\sim 5 \times 10^{-5} \mathrm{~mol} / \mathrm{L} \mathrm{HCO}_{3}{ }^{-}\right)$, at low total Am(III) concentrations $\left(\sim 10^{-8} \mathrm{~mol} / \mathrm{L}\right)$ and over reaction times of 1 hour to 1 week.

Colloidal hematite was used in all experiments. However, two sources of hematite were used: commercial and laboratory-synthesized. All the data were fit and the resulting NEM constants are listed in Table 1. The data of Cromieres (1996) were the only published Am(III)-iron oxide sorption data available and the average NEM constants reported in Table 2 are based on the average fit to these data. The predicted sorption based on the average NEM constants are plotted along with the data in Figures 1 to 4. The average $\log K$ constants are $1.24 \pm 0.43$ and $-15.29 \pm 0.37$ for $>\mathrm{FeOAm}^{2+}$ and $>\mathrm{FeOAm}(\mathrm{OH})_{2}$, respectively.

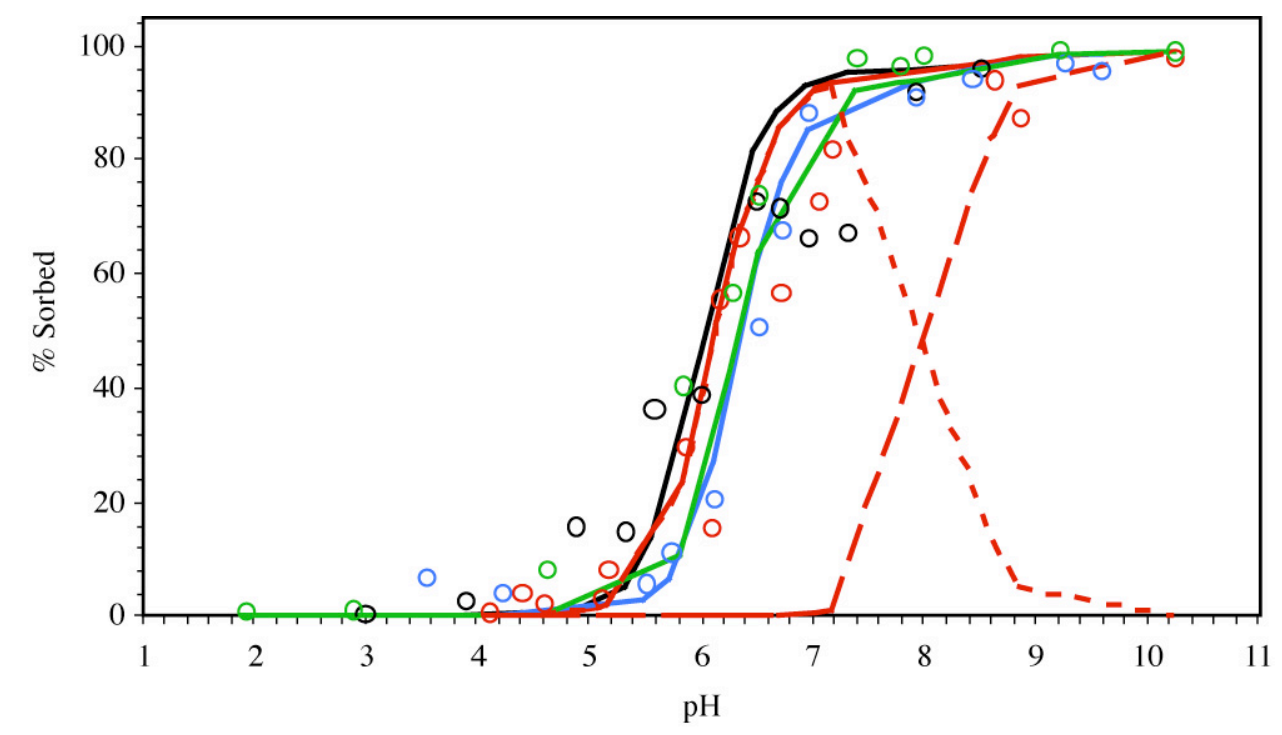

Figure 1. Sorption of $\mathrm{Am}$ (III) on $\alpha-\mathrm{Fe}_{2} \mathrm{O}_{3}$. Solid lines represent model prediction using NEM

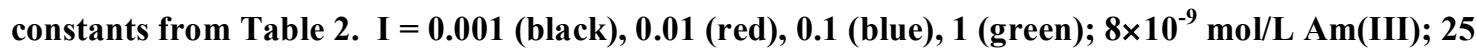
$\mathrm{mg} / \mathrm{L} \mathrm{Fe}_{2} \mathrm{O}_{3} ; 19 \mathrm{~m}^{2} / \mathrm{g} \mathrm{Fe}_{2} \mathrm{O}_{3}$; data from Cromieres (1996); dashed lines = individual species contributions. 


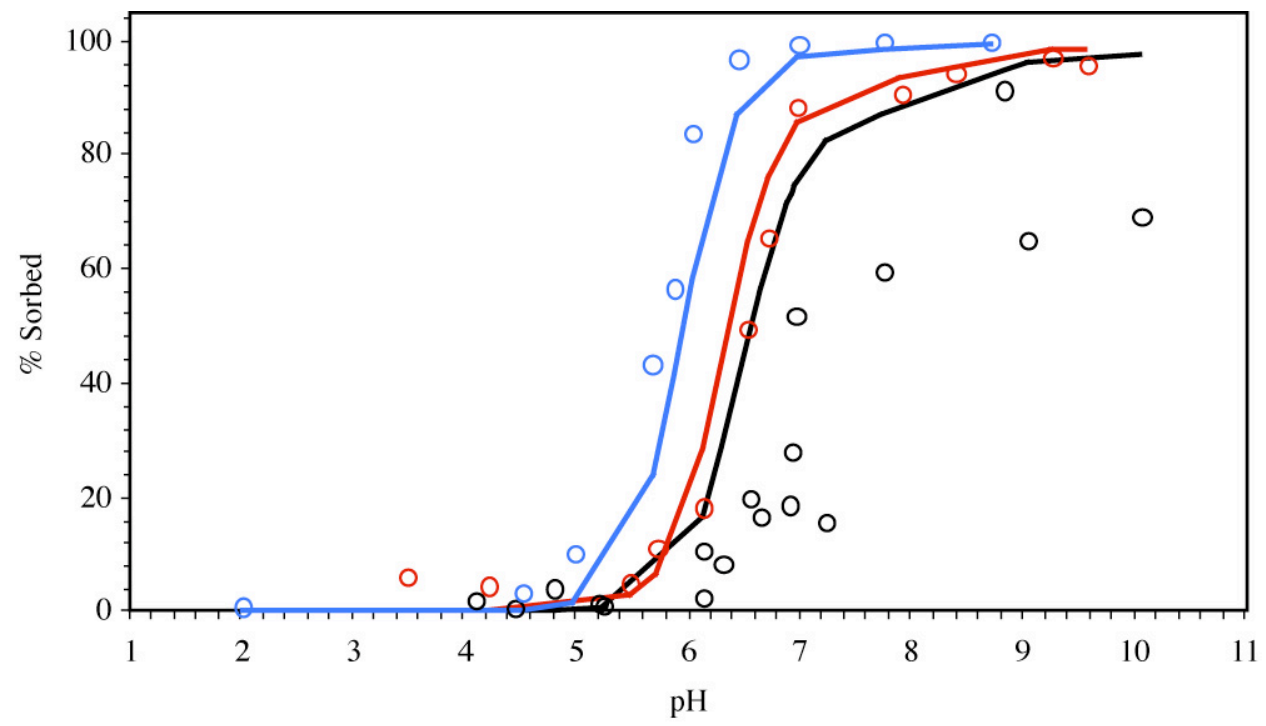

Figure 2. Sorption of $\mathrm{Am}$ (III) on $\alpha-\mathrm{Fe}_{2} \mathrm{O}_{3}$. Solid lines represent model prediction using NEM constants from Table 2. I = 0.1; 8×10 ${ }^{-9} \mathrm{~mol} / \mathrm{L} \mathrm{Am}$ (III); 12.5 (black), 25 (red), 125 (blue) $\mathrm{mg} / \mathrm{L} \mathrm{Fe}_{2} \mathrm{O}_{3}$; $19 \mathrm{~m}^{2} / \mathrm{g} \mathrm{Fe}_{2} \mathrm{O}_{3}$; data from Cromieres (1996).

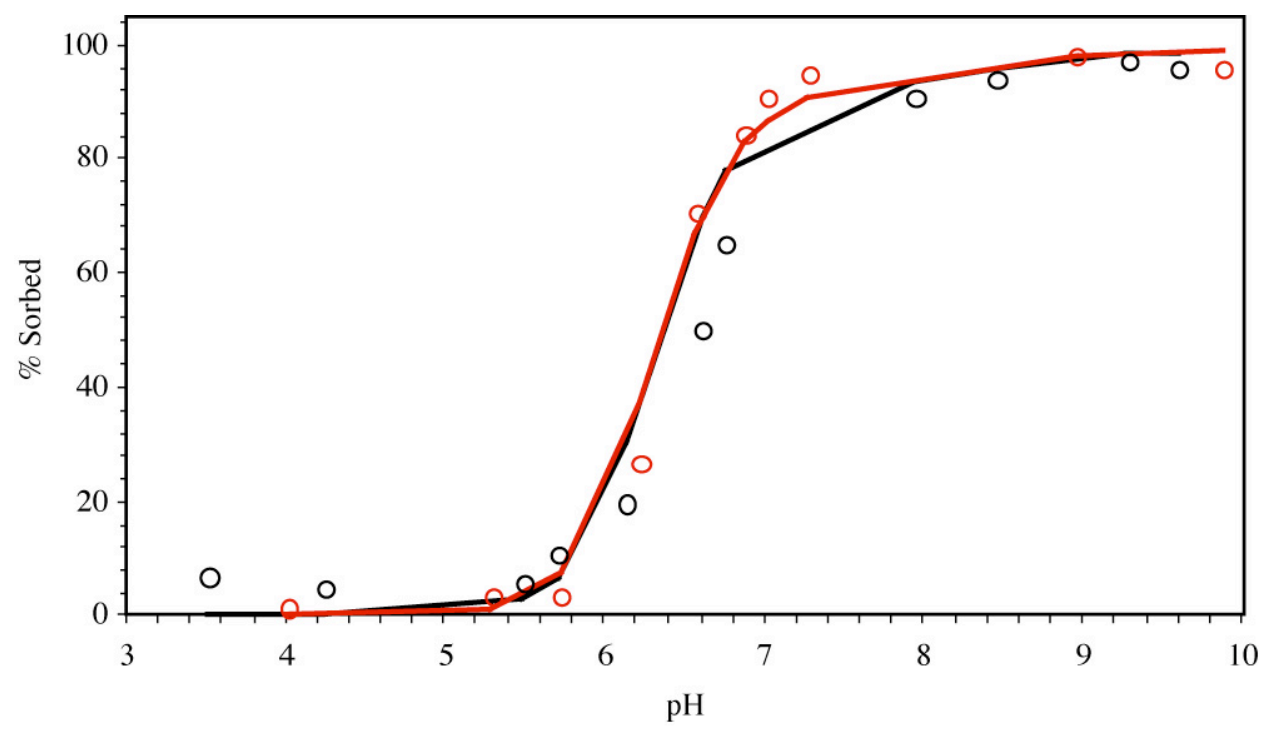

Figure 3. Sorption of $\mathrm{Am}$ (III) on $\alpha-\mathrm{Fe}_{2} \mathrm{O}_{3}$. Solid lines represent model prediction using NEM constants from Table 2. $\mathrm{I}=0.1 ; 8 \times 10^{-9}$ (black), $1.5 \times 10^{-9}$ (red) mol/L Am(III); $25 \mathrm{mg} / \mathrm{L} \mathrm{Fe}_{2} \mathrm{O}_{3} ; 19 \mathrm{~m}^{2} / \mathrm{g}$ $\mathrm{Fe}_{2} \mathrm{O}_{3}$; data from Cromieres (1996). 


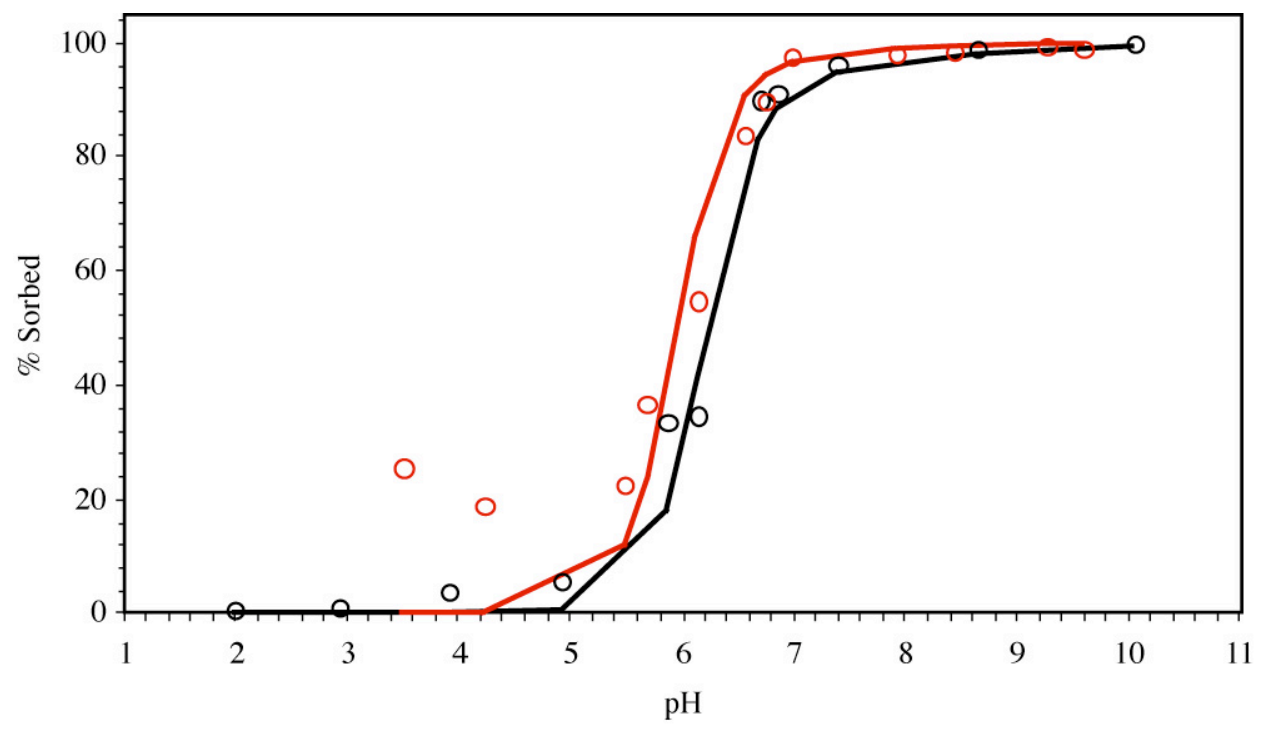

Figure 4. Sorption of $\mathrm{Am}$ (III) on $\alpha-\mathrm{Fe}_{2} \mathrm{O}_{3}$. Solid lines represent model prediction using NEM constants from Table 2. I = 0.1; 8×10 ${ }^{-9} \mathrm{~mol} / \mathrm{L} \mathrm{Am(III);} 100$ (black), 125 (red) $\mathrm{mg} / \mathrm{L} \mathrm{Fe}_{2} \mathrm{O}_{3} ; 8$ (black), 19 (red) $\mathrm{m}^{2} / \mathrm{g} \mathrm{Fe}_{2} \mathrm{O}_{3}$; data from Cromieres (1996).

\subsection{Am(III) on Calcite}

Am(III) sorption experiments of Shanbhag and Morse (1982) consisted of sequential addition of Am(III) to a solution consisting of $5 \mathrm{mg}$ calcite per gram calcite-equilibrated seawater at $\sim \mathrm{pH} 8$. The data and NEM fits consisted of 10 sequential Am(III) spike additions to effect a total concentration range of 7 to $70 \mathrm{nmol} / \mathrm{L} \mathrm{Am}(\mathrm{III})$. As can be seen from data fits listed in Table 1, within this range, fitted NEM constants did not vary between spikes and result in an average Am(III) $\log K$ of $4.13 \pm 0.06$ (Table 3 ).

For all experiments described by Shabhag and Morse (1982), calcite reduced the Am(III) concentration in solution by 98 to 99 percent. It is, therefore, likely that Am(III) will be largely immobile in geologic media with significant calcite, particularly at $\sim \mathrm{pH} 8$. As $\mathrm{pH}$ deviates from $\sim 8.0$, the sorptive capacity of calcite for Am(III) may change; additional experimental data is needed to determine the effect of $\mathrm{pH}$. However, it is expected that the behavior of $\mathrm{Am}$ (III) as a function of $\mathrm{pH}$ will parallel that of $\mathrm{Eu}(\mathrm{III})$, described in Section 3.4.

\subsection{Eu(III) on Iron Oxide Minerals}

$\mathrm{Eu}(\mathrm{III})$ sorption to iron oxide minerals has been reported in several references (Catalette et al., 1998; Fujita and Tsukamoto, 1997; Ledin et al., 1994; Rabung et al., 1998). Catalette et al. (1998) examined the sorption of Eu(III) at very high concentrations 
$\left(2 \times 10^{-4} \mathrm{~mol} / \mathrm{L}\right)$. At this concentration, either surface precipitation or direct precipitation is likely. In addition, the total $\mathrm{Eu}(\mathrm{III})$ concentration exceeds the number of surface sites available for sorption $(0.0002$ and $0.00014 \mathrm{~mol} / \mathrm{L}$, respectively). For these reasons, this data set was not fit. Fujita and Tsukamoto (1997) examined the sorption of $\mathrm{Eu}(\mathrm{III})$ to goethite and hematite minerals at low and high carbonate alkalinity. Sorption experiments were conducted with $10^{-5} \mathrm{~mol} / \mathrm{L} \mathrm{Eu}(\mathrm{III})$; at this concentration, precipitation is likely. The potential for $\mathrm{Eu}(\mathrm{OH})_{3}$ precipitation above $\mathrm{pH} 9$ was mentioned by the authors, though REACT (Bethke, 1998) measurements indicate that $\mathrm{EuOHCO}_{3}$ is also likely to precipitate at $\mathrm{pH}$ 6-7. The shift in the sorption edge attributed by Fujita and Tsukamoto (1997) to formation of europium carbonate surface complexes may actually be the result of $\mathrm{EuOHCO}_{3}$ precipitation. For these reasons, the quality of $\mathrm{Eu}(\mathrm{III})$ sorption data of Fujita and Tsukamoto (1997) is questionable. Nevertheless, fits to data are listed in Table 1 (data fit assuming no precipitation).

$\mathrm{Eu}(\mathrm{III})$ sorption data of Ledin et al. (1994) consisted of 3 sets of experiments performed open to the atmosphere and using $\mathrm{Fe}(\mathrm{OH})_{3}, \mathrm{FeOOH}$, or $\mathrm{Fe}_{2} \mathrm{O}_{3}$ as the sorbing mineral (Figures 5 to 7). The data were fit using one surface complex. When all three sorption fitting results are averaged, the $\log K$ for $>\mathrm{FeOEu}^{2+}$ is $1.86 \pm 0.67$ (Table 2).

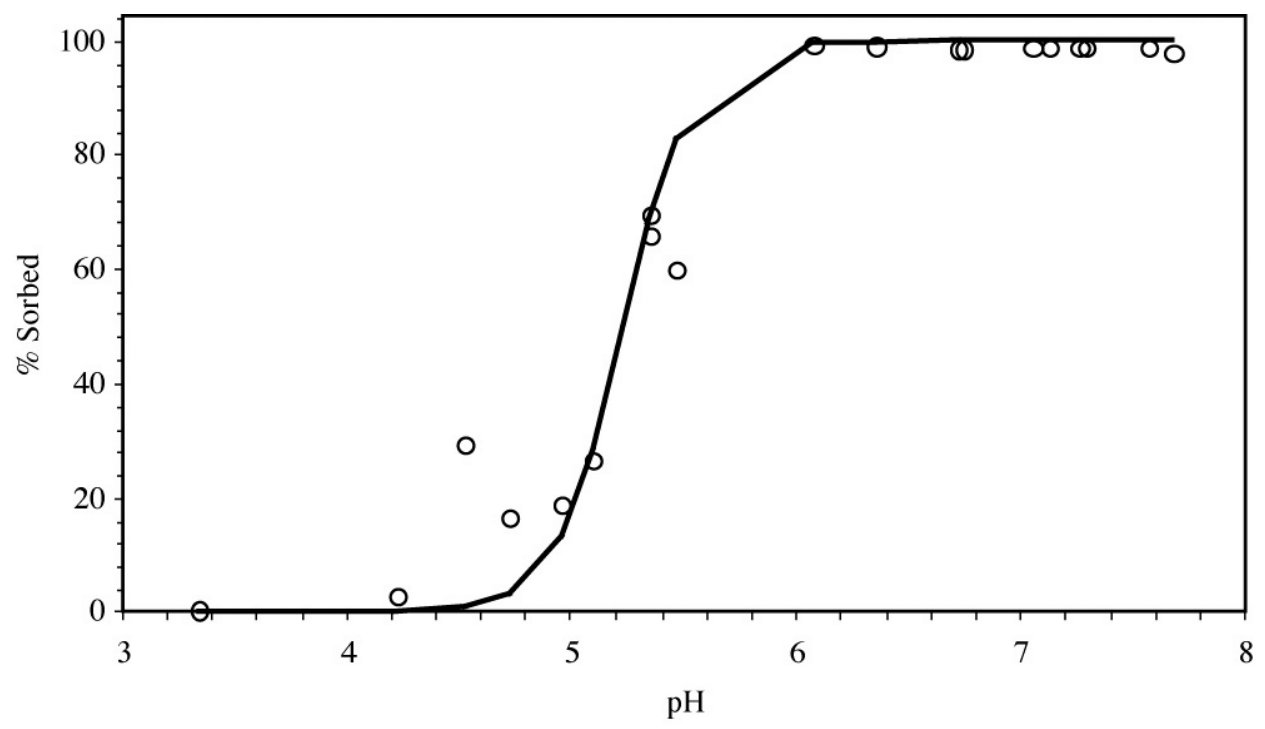

Figure 5. Sorption of Eu(III) on FeOOH. Solid lines represent model prediction using NEM constants from Table $2 . \mathrm{I}=0.01 ; 10^{-8} \mathrm{~mol} / \mathrm{L} \mathrm{Eu}(\mathrm{III}) ; 250 \mathrm{mg} / \mathrm{L} \mathrm{FeOOH} ; 62 \mathrm{~m}^{2} / \mathrm{g} \mathrm{FeOOH}$; data from Ledin et al. (1994). 


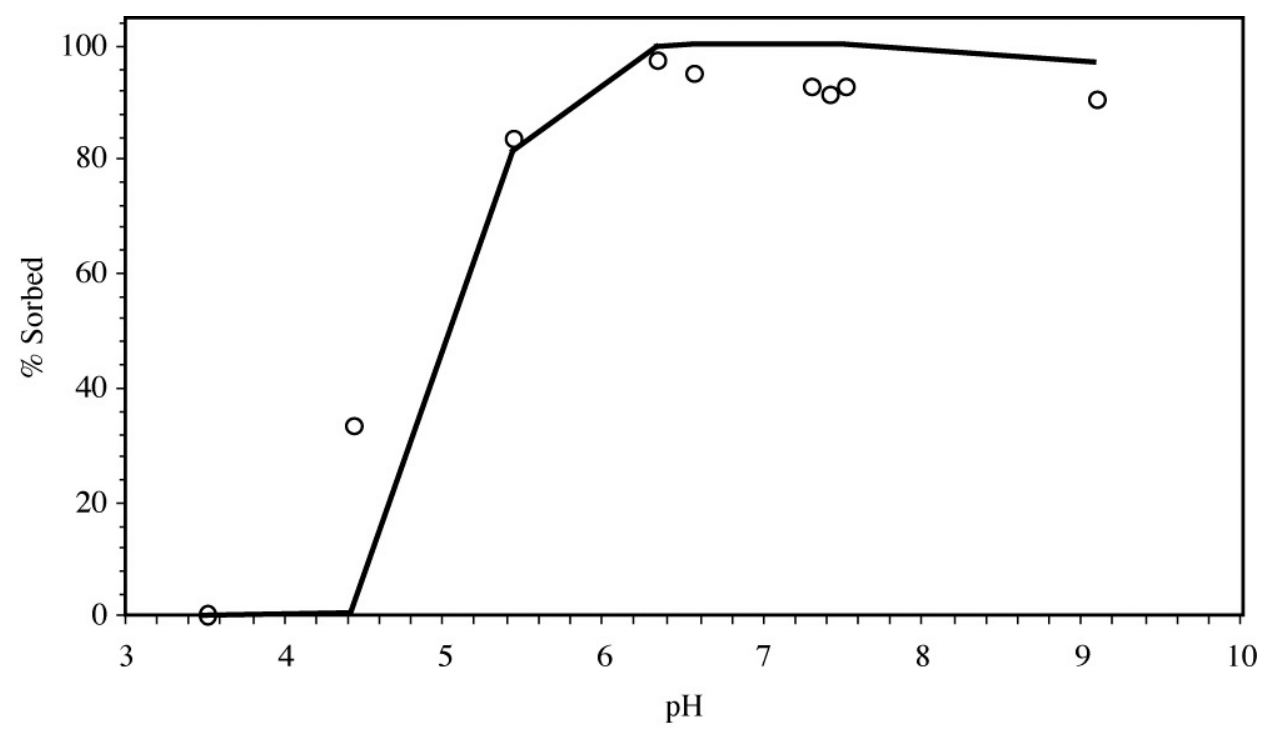

Figure 6. Sorption of $\mathrm{Eu}(\mathrm{III})$ on $\mathrm{Fe}(\mathrm{OH})_{3}$. Solid lines represent model prediction using NEM constants from Table $2 . \mathrm{I}=0.01 ; 10^{-8} \mathrm{~mol} / \mathrm{L} \mathrm{Eu}(\mathrm{III}) ; 50 \mathrm{mg} / \mathrm{L} \mathrm{Fe}(\mathrm{OH})_{3} ; 320 \mathrm{~m}^{2} / \mathrm{g} \mathrm{Fe}(\mathrm{OH})_{3}$; data from Ledin et al. (1994).

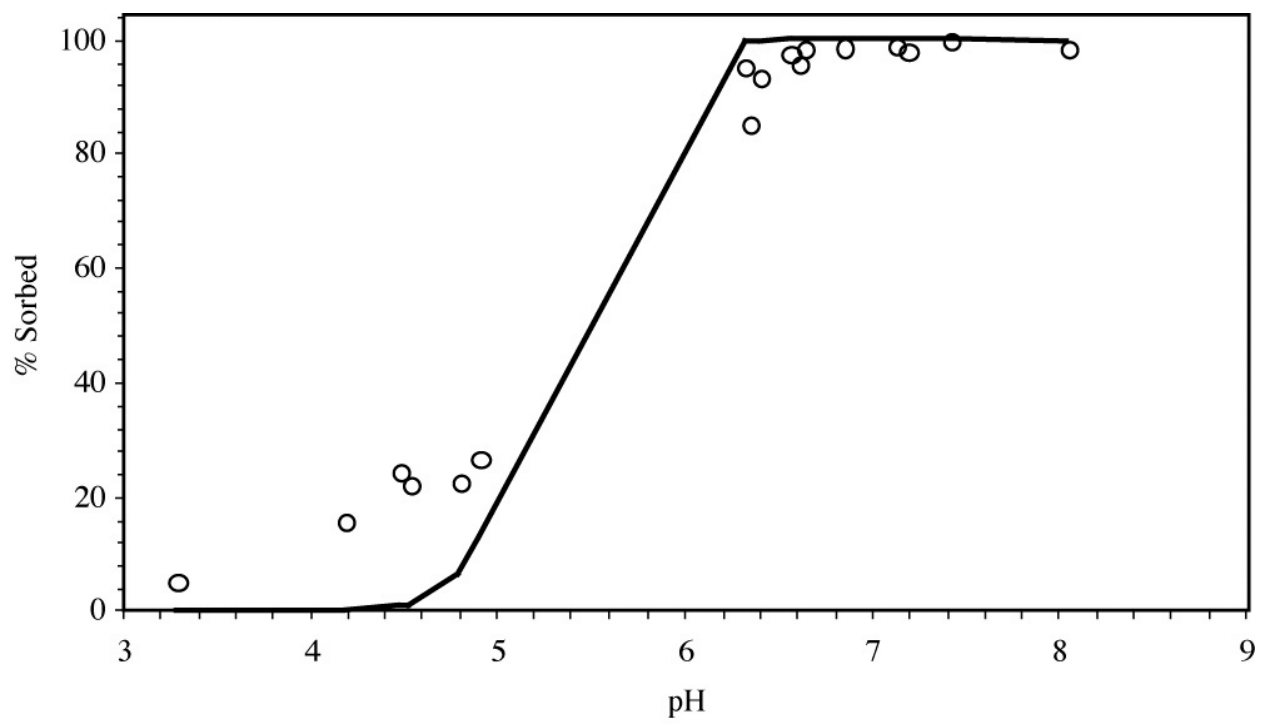

Figure 7. Sorption of $\mathrm{Eu}$ (III) on $\mathrm{Fe}_{2} \mathrm{O}_{3}$. Solid lines represent model prediction using NEM constants from Table 2. I $=0.01 ; 10^{-8} \mathrm{~mol} / \mathrm{L} \mathrm{Eu}(\mathrm{III}) ; 500 \mathrm{mg} / \mathrm{L} \mathrm{Fe}_{2} \mathrm{O}_{3} ; 43 \mathrm{~m}^{2} / \mathrm{g} \mathrm{Fe}_{2} \mathrm{O}_{3}$; data from Ledin et al. (1994).

Rabung et al. (1998) investigated the sorption of $\mathrm{Eu}(\mathrm{III})$ on natural hematite as a function of $\mathrm{pH}$ (sorption envelope) and also as a function of surface load (sorption isotherm) in the absence of $\mathrm{CO}_{2}(\mathrm{~g})$. Surface loading for two sorption envelope data sets was relatively high (4 and 40\% surface load estimated in Rabung et al. (1998); $1.79 \times 10^{-6}$ and $1.79 \times 10^{-5}$ $\mathrm{mol} / \mathrm{L} \mathrm{Eu(III)} \mathrm{initial} \mathrm{concentration).} \mathrm{For} \mathrm{the} \mathrm{high} \mathrm{surface} \mathrm{load} \mathrm{data} \mathrm{set,} \mathrm{precipitation} \mathrm{of}$ 
$\mathrm{Eu}(\mathrm{OH})_{3}$ is predicted above $\mathrm{pH}$ 7. Surface precipitation, colloid formation, or precipitation is likely to have affected these data. For these reasons, the quality of these sorption data is questionable. Nevertheless, fits to these data (assuming no precipitation) are listed in Table 1 and data are shown in Figures 8 and 9. Fits suggest that a second surface complex is needed $\left(>\mathrm{FeOEu}(\mathrm{OH})_{2}\right.$; Table 1$)$; the need for a second surface complex is consistent with the Am(III) results. However, this second surface complex improved the fit to the data only slightly.

The over-prediction of sorption between $\mathrm{pH} 5$ and 7 at high surface loads (Figure 8) suggests that a two-site model may be necessary to adequately fit Eu(III) sorption at high surface loads. This is consistent with the sorption isotherm data of Rabung et al. (1998). The under-prediction of sorption based on the average NEM constants from Ledin et al. (1994) at lower surface loads and at low pH (Figure 9) may result from a significant difference in the charging behavior of the iron oxide of Rabung et al. (1998) compared to that of Ledin et al. (1994). Ledin et al. (1994) reported that the $\mathrm{pH}_{\mathrm{pzc}}$ of their iron oxides were in the upper range of reported values while the $\mathrm{pH}_{\mathrm{pzc}}$ of Rabung et al. (1998) was reported to be at the lower end. A lower $\mathrm{pH}_{\mathrm{pzc}}$ will result in a greater negative surface charge at low $\mathrm{pH}$ which would increase Eu(III) sorption at low $\mathrm{pH}$ (Figures 8 and 9).

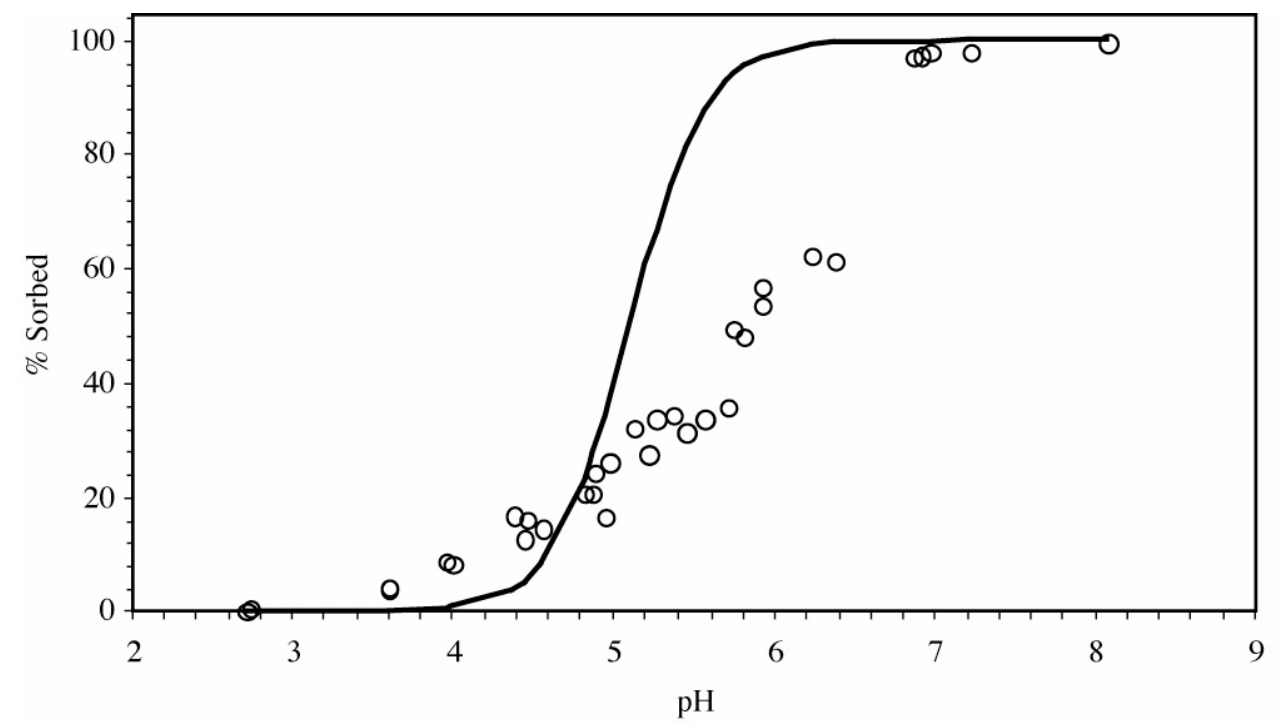

Figure 8. Sorption of $\mathrm{Eu}(\mathrm{III})$ on $\mathrm{Fe}_{2} \mathrm{O}_{3}$. Solid lines represent model prediction using NEM constants from Table 2. $\mathrm{I}=0.1 ; 1.79 \times 10^{-5} \mathrm{~mol} / \mathrm{L} \mathrm{Eu}(\mathrm{III}) ; 1.02 \times 10^{-4} \mathrm{~mol} / \mathrm{L} \mathrm{Fe}_{2} \mathrm{O}_{3}$ sites; data from Rabung et al. (1998). 


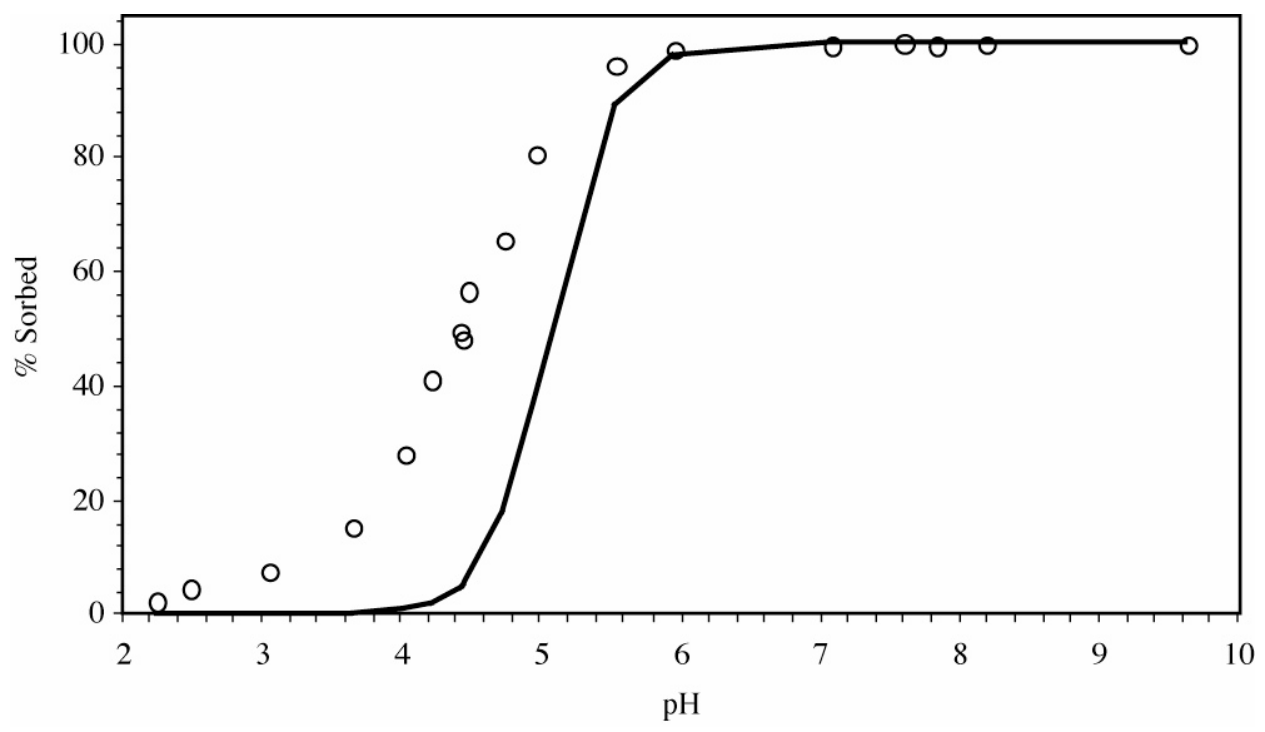

Figure 9. Sorption of $\mathrm{Eu}(\mathrm{III})$ on $\mathrm{Fe}_{2} \mathrm{O}_{3}$. Solid lines represent model prediction using NEM constants from Table 2. $\mathrm{I}=0.1 ; 1.79 \times 10^{-6} \mathrm{~mol} / \mathrm{L} \mathrm{Eu}(\mathrm{III}) ; 1.02 \times 10^{-4} \mathrm{~mol} / \mathrm{L} \mathrm{Fe}_{2} \mathrm{O}_{3}$ sites; data from Rabung et al. (1998).

Figures 10 to 13 present the sorption isotherm data from Rabund et al. (1998) and model prediction (only data with $<10 \%$ surface load are shown) using the average NEM constants from Ledin et al. (1994). Rabung et al. (1998) used a two-site constant capacitance model to fit these data because sorption was non-linear at high $\mathrm{Eu}(\mathrm{III})$ surface loads. Non-linear sorption occurred at surface loads greater than $\sim 10 \%$. This non-linearity cannot be fit with a one-site model. With the one-site model, data fits could be optimized for low surface loads would overestimate sorption at high surface loads. However, high surface loads of $\mathrm{Eu}(\mathrm{III})$ or other radionuclides are not likely to occur at the NTS, though these results show that the NEM constants reported here should not be used in areas with high radionuclide concentrations. The average NEM constants from Ledin et al. (1994) fit the isotherm data of Rabung et al. (1998) at low surface loads (except for $\mathrm{pH} 4$ data). This suggests that the data of Ledin et al. (1994) and Rabung et al. (1998) are consistent at low surface loads. 


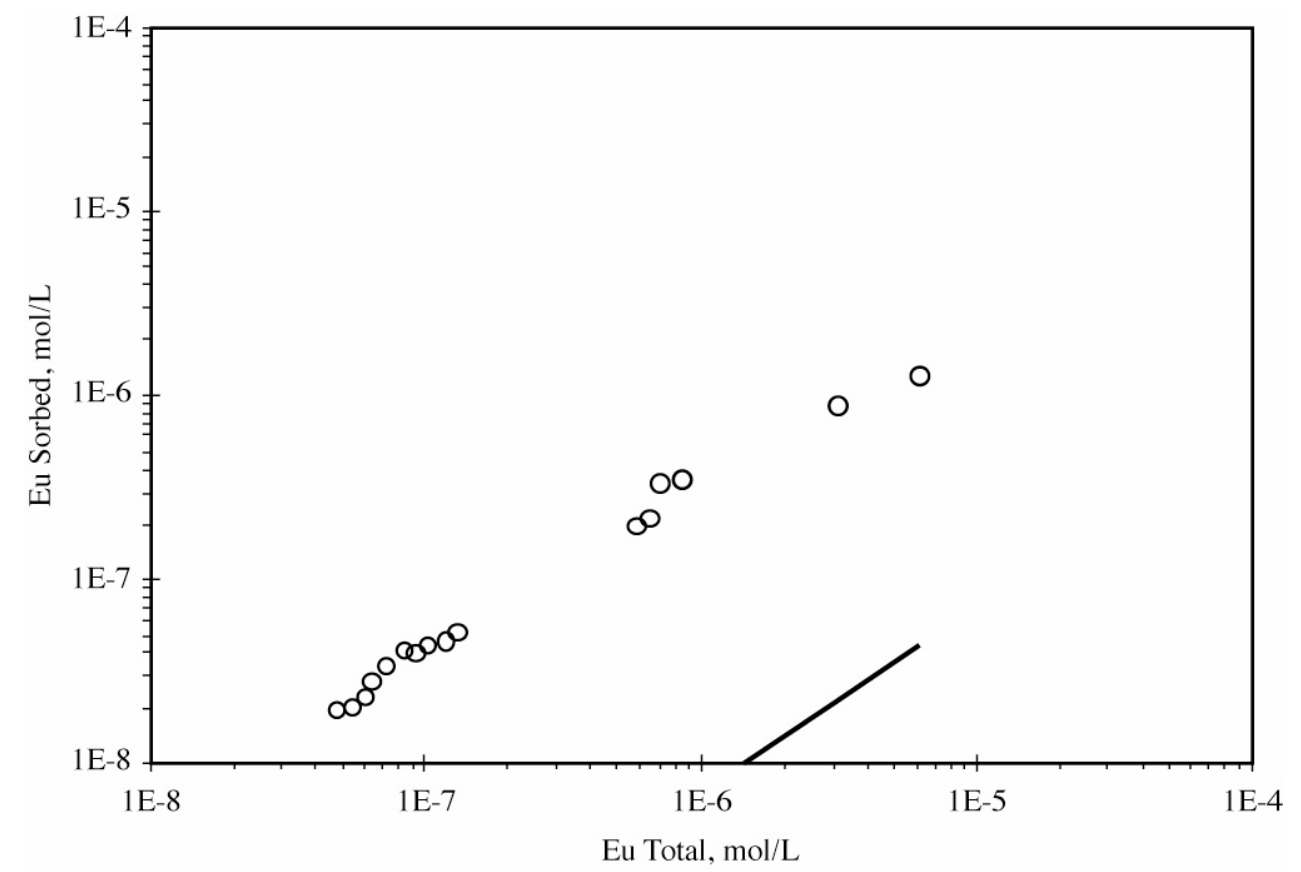

Figure 10. Sorption of $\mathrm{Eu}$ (III) on $\mathrm{Fe}_{2} \mathrm{O}_{3}$ at $\mathrm{pH} 4$ as a function of added $\mathrm{Eu}$ (III) (aqueous $\mathrm{Eu}<10^{-5}$ $\mathrm{mol} / \mathrm{L}$ ) at low surface loads. Solid lines represent model prediction using NEM constants from Table 2. $\mathrm{I}=0.1 ; 1.02 \times 10^{-4} \mathrm{~mol} / \mathrm{L} \mathrm{Fe}_{2} \mathrm{O}_{3}$ sites; data from Rabung et al. (1998).

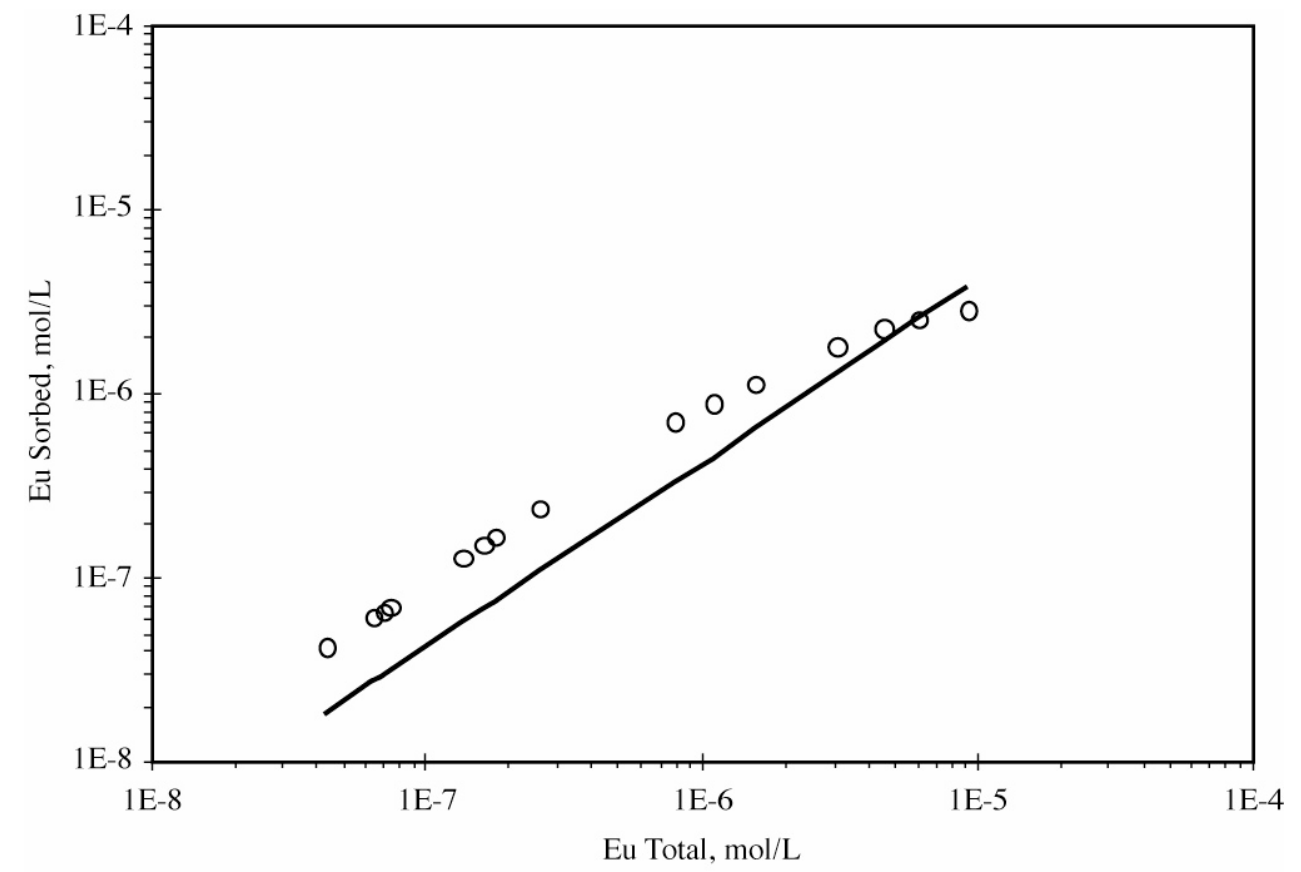

Figure 11. Sorption of $\mathrm{Eu}$ (III) on $\mathrm{Fe}_{2} \mathrm{O}_{3}$ at $\mathrm{pH} 5$ as a function of added $\mathrm{Eu}$ (III) (aqueous $\mathrm{Eu}<10^{-5}$ mol/L) at low surface loads. Solid lines represent model prediction using NEM constants from Table 2. $\mathrm{I}=0.1 ; 1.02 \times 10^{-4} \mathrm{~mol} / \mathrm{L} \mathrm{Fe}_{2} \mathrm{O}_{3}$ sites; data from Rabung et al. (1998). 


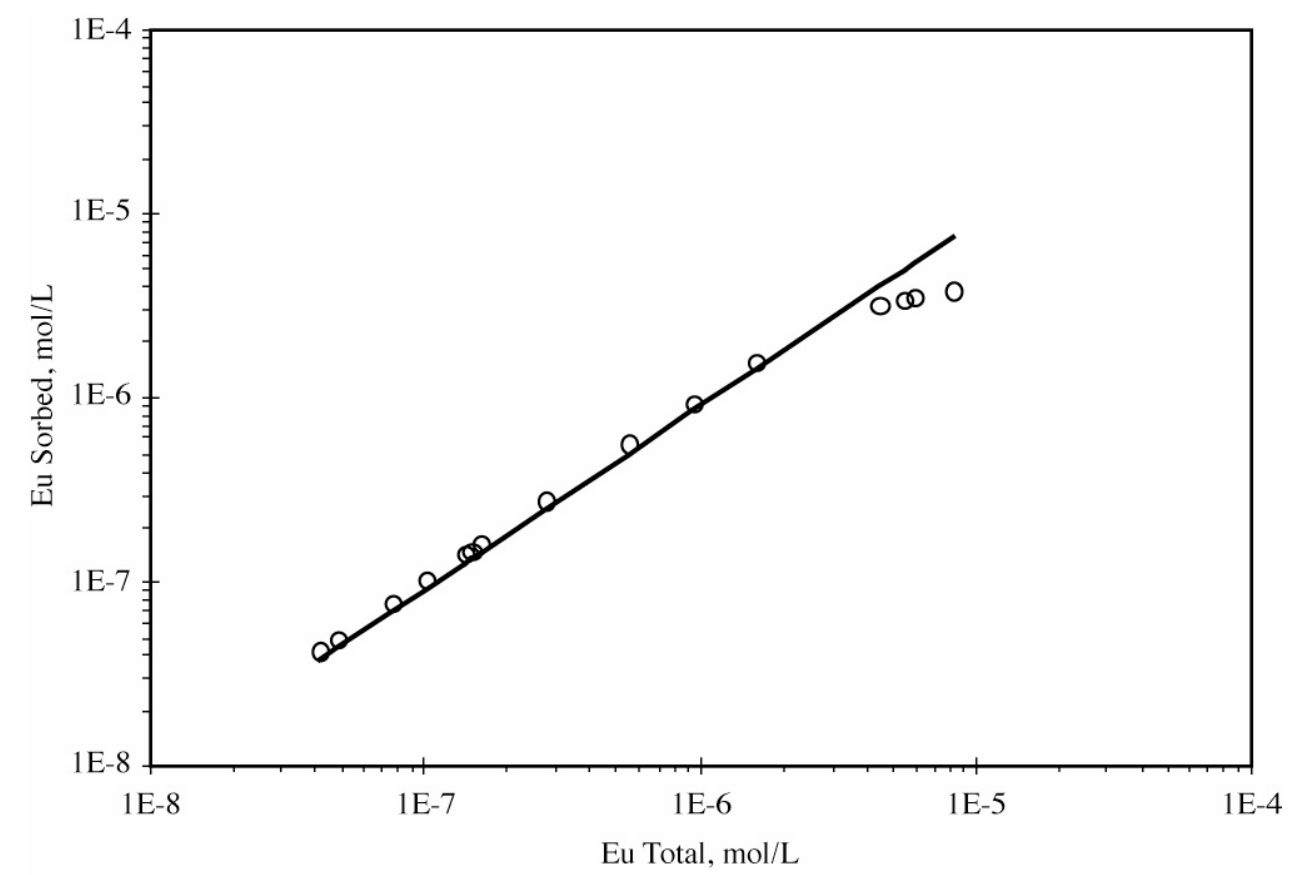

Figure 12. Sorption of $\mathrm{Eu}(\mathrm{III})$ on $\mathrm{Fe}_{2} \mathrm{O}_{3}$ at $\mathrm{pH} 5.5$ as a function of added $\mathrm{Eu}$ (III) (aqueous $\mathrm{Eu}<10^{-5}$ $\mathrm{mol} / \mathrm{L}$ ) at low surface loads. Solid lines represent model prediction using NEM constants from Table 2. $\mathrm{I}=0.1 ; 1.02 \times 10^{-4} \mathrm{~mol} / \mathrm{L} \mathrm{Fe}_{2} \mathrm{O}_{3}$ sites; data from Rabung et al. (1998).

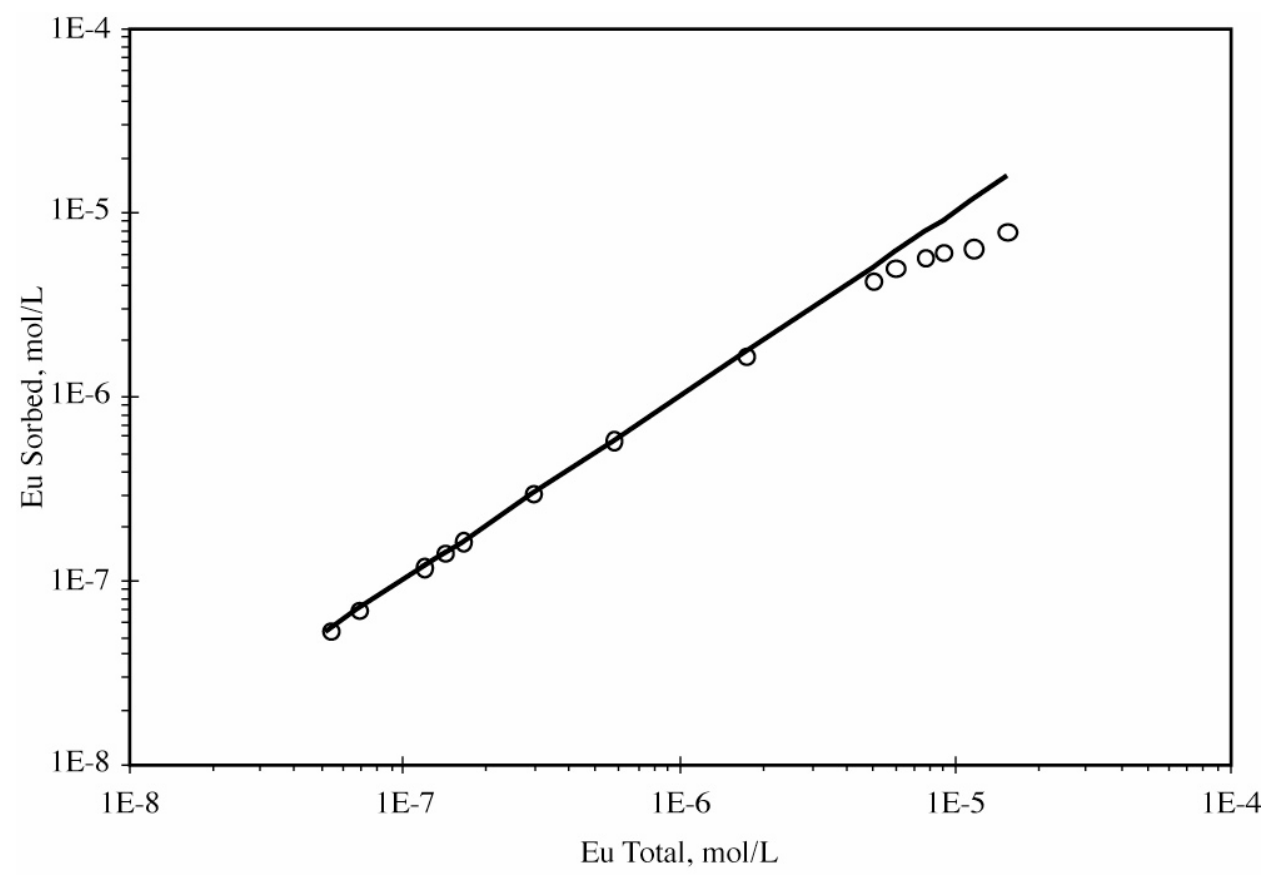

Figure 13. Sorption of $\mathrm{Eu}$ (III) on $\mathrm{Fe}_{2} \mathrm{O}_{3}$ at $\mathrm{pH} 6$ as a function of added $\mathrm{Eu}$ (III) (aqueous $\mathrm{Eu}<10^{-5}$ mol/L) at low surface loads. Solid lines represent model prediction using NEM constants from Table 2. $I=0.1 ; 1.02 \times 10^{-4} \mathrm{~mol} / \mathrm{L} \mathrm{Fe}_{2} \mathrm{O}_{3}$ sites; data from Rabung et al. (1998). 
Average NEM constants calculated from fits to the sorption data of Ledin et al. (1994) were considered the most appropriate for use in reactive transport models at low radionuclide loads (Table 2). If all available data sets were averaged, the Log $K$ constant for $>\mathrm{FeOEu}^{2+}$ would be $1.7 \pm 1.3$. This values is nearly equal to the Ledin et al. (1994) data fit, though the standard deviation is much greater.

\subsection{Eu(III) on Calcite}

Zhong and Mucci (1995) performed sorption and coprecipitation experiments using a cocktail of 12 rare earth elements at relatively high concentrations (single $\mathrm{pH}$ data). In the data fits, it was assumed that there was no significant competition for surface sites between the various rare earth elements. Thus, fitted NEM constants based on these data are likely to be low. Fit results are reported in Table 1. Comparison of sorption and coprecipitation results indicate that the Doerner-Hoskins extrapolation of coprecipitation to sorption was reasonably good (see summary discussion in Section 4).

Coprecipitation data was available from Terakado and Masuda (1988). However, they used a $\mathrm{pH}$-drift coprecipitation technique from which NEM constant fitting could not be easily accomplished. Fits to the data of Terakado and Masuda (1988) were not attempted.

Sorption envelope data for $\mathrm{Eu}(\mathrm{III})$ on calcite in atmospheric $\mathrm{CO}_{2}(\mathrm{~g})$ equilibrated waters were collected for the UGTA program in FY2000. Details regarding this data were presented in an earlier internal report. This internal report is included here as Appendix A. The resulting fitted NEM constant is listed in Table 1 and is significantly greater than that based on the data of Zhong and Mucci (1995). This was expected given the data fitting assumptions used for the data of Zhong and Mucci (1995). The fitted NEM constant based on the sorption envelope data is reported in Table 3.

\section{5 $\mathrm{Np}(\mathrm{V})$ on Iron Oxide Minerals}

Two references regarding $\mathrm{Np}(\mathrm{V})$ sorption to iron oxide minerals were examined (Girvin et al., 1991; Nakayama and Sakamoto, 1991). Experiments of Girvin et al. (1991) were batch sorption experiments on $\mathrm{Fe}(\mathrm{OH})_{3}$ with $\mathrm{Np}(\mathrm{V})$ concentrations in the range of $10^{-13}$ to $10^{-11} \mathrm{~mol} / \mathrm{L}$. Total inorganic carbonate was measured for several sorption experiments to determine whether batch solutions were in equilibrium with atmospheric $\mathrm{CO}_{2}$. Girvin et al. (1991) found that total carbonate in solution remained near $5 \times 10^{-5} \mathrm{~mol} / \mathrm{L}$ at all $\mathrm{pH}$, deviating significantly from atmospheric equilibrium at high $\mathrm{pH}$. This information was critical to NEM constant determination because formation of neptunyl carbonate aqueous complexes may significantly reduce the sorptive potential of iron oxide minerals. The results are presented in Figures 14 and 15. Two surface species were required to adequately fit the sorption data; the influence of the two species is shown in Figure 15. The $\log \mathrm{K}$ for $>\mathrm{FeOHNpO}_{2}{ }^{+}$was nearly constant for all 5 data sets and the average 
(4.32 \pm 0.11$)$ is reported in Table 2. The $\mathrm{Log} K$ of $>\mathrm{FeOHNpO}_{3}{ }^{-}$varied significantly (Table 1). Because the $>\mathrm{FeOHNpO}_{3}{ }^{-}$species contributed to sorption only at high $\mathrm{pH}$, small variations in the assigned $\log K$ constant did not significantly affect the fit to most data. As a conservative estimate, the lowest fitted Log $K$ constant was included in Table 2 (-11.26). The average and standard deviation when all fitting results are included is $4.32 \pm 0.11$ for $>\mathrm{FeOHNpO}_{2}{ }^{+}$and $-9.85 \pm 1.19$ for $>\mathrm{FeOHNpO}_{3}$. The surface complexation constants reported in Table 2 are more conservative.

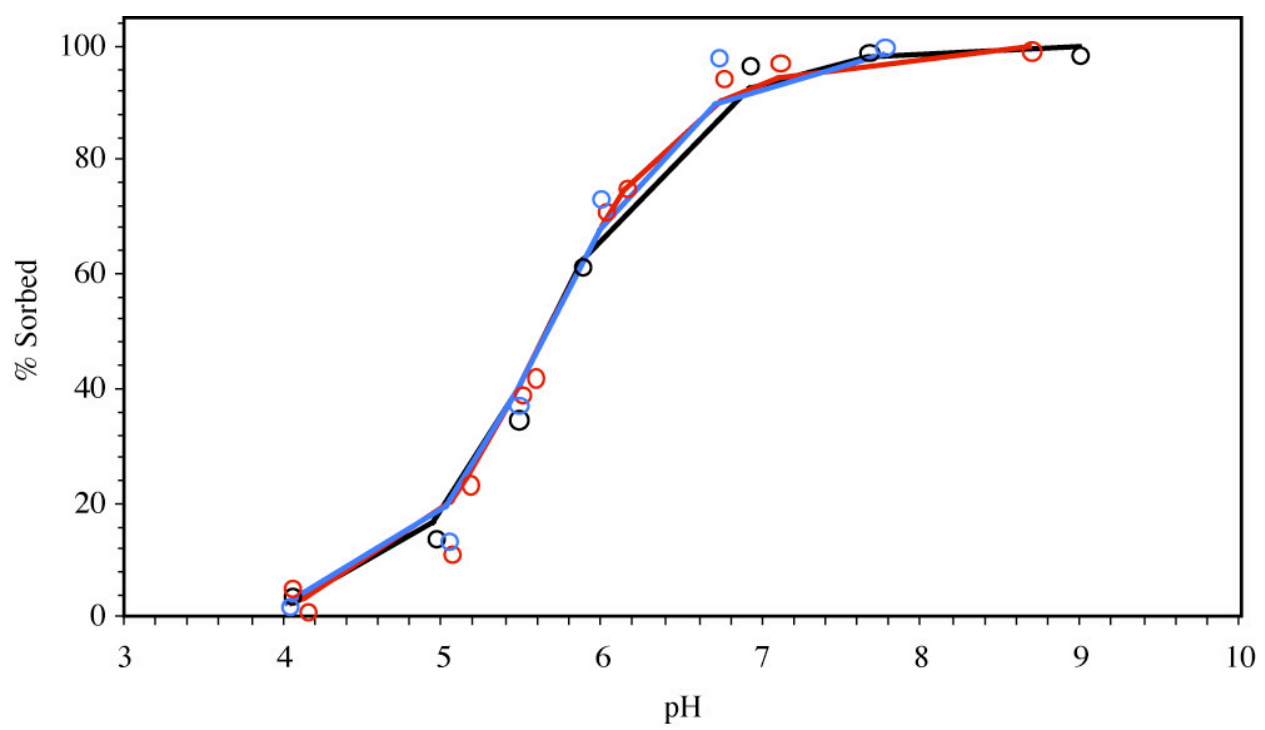

Figure 14. Sorption of $4.5 \times 10^{-11}$ (black), $4.7 \times 10^{-12}$ (red), and $4.5 \times 10^{-13}$ (blue) $\mathrm{mol} / \mathrm{L} \mathrm{Np(V)} \mathrm{on}$ $\mathrm{Fe}(\mathrm{OH})_{3}$. Solid lines represent model prediction using NEM constants from Table $2 . \mathrm{I}=0.1 ; 10^{-2}$ $\mathrm{mol} / \mathrm{L} \mathrm{Fe}$ as $\mathrm{Fe}(\mathrm{OH})_{3}$; open to air; data from Girvin et al. (1991). 


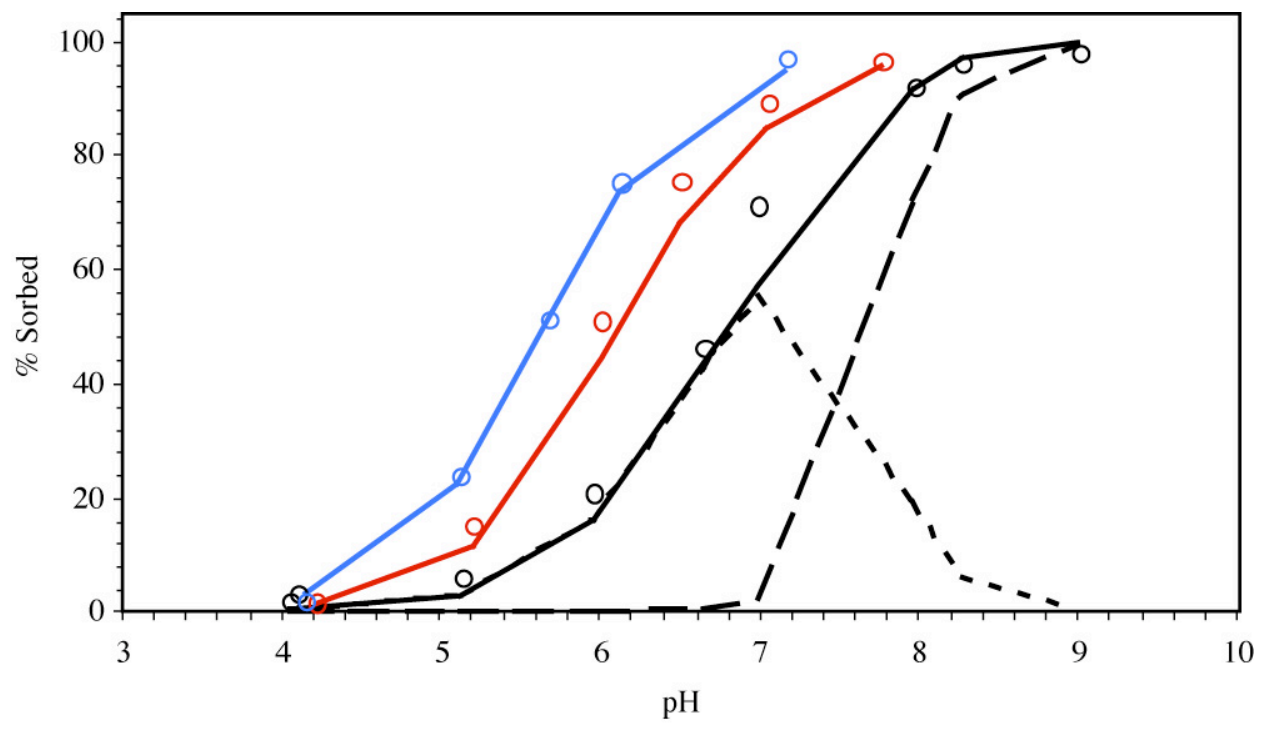

Figure 15. Sorption of $\mathrm{Np}(\mathrm{V})$ on $\mathrm{Fe}(\mathrm{OH})_{3}$. Solid lines represent model prediction using NEM constants from Table 2. $\mathrm{I}=0.1 ; \mathrm{Np}(\mathrm{V})=4.7 \times 10^{-12} \mathrm{~mol} / \mathrm{L} ; 0.001$ (black), 0.0037 (red), and 0.01 (blue) $\mathrm{mol} / \mathrm{L} \mathrm{Fe}$ as $\mathrm{Fe}(\mathrm{OH})_{3}$; open to air; data from Girvin et al. (1991); dashed lines = individual species contributions.

The data of Nakayama and Sakamoto (1991) was found to be questionable for several reasons (results are, nevertheless, reported in Table 1 and Figures 16 and 17). First, there was no control over the total inorganic carbon in batch solutions and, therefore, the influence of aqueous carbonate complexation could not be adequately assessed. Second, the concentration of $\mathrm{Np}(\mathrm{V})$ in solution was approximately $6 \times 10^{-6} \mathrm{~mol} / \mathrm{L}, 6$ orders of magnitude higher than the experiments of Girvin et al. (1991). At this concentration, approximately $10 \%$ of the iron oxide surface was predicted to be loaded with $\mathrm{Np}$. This is a surface load much greater than expected in most NTS environments and a surface load at which more complex surface precipitation reactions may become significant. Figures 16 and 17 present the data and model results using the NEM constants reported in Table 2. Though the model does not match the data very well, the general trend in the data and model are in agreement. In fact, the average NEM constants based on all four NEM fit results listed in Table 1 are similar to the NEM constants determined solely from data of Girvin et al. (1991) and reported in Table 2. 


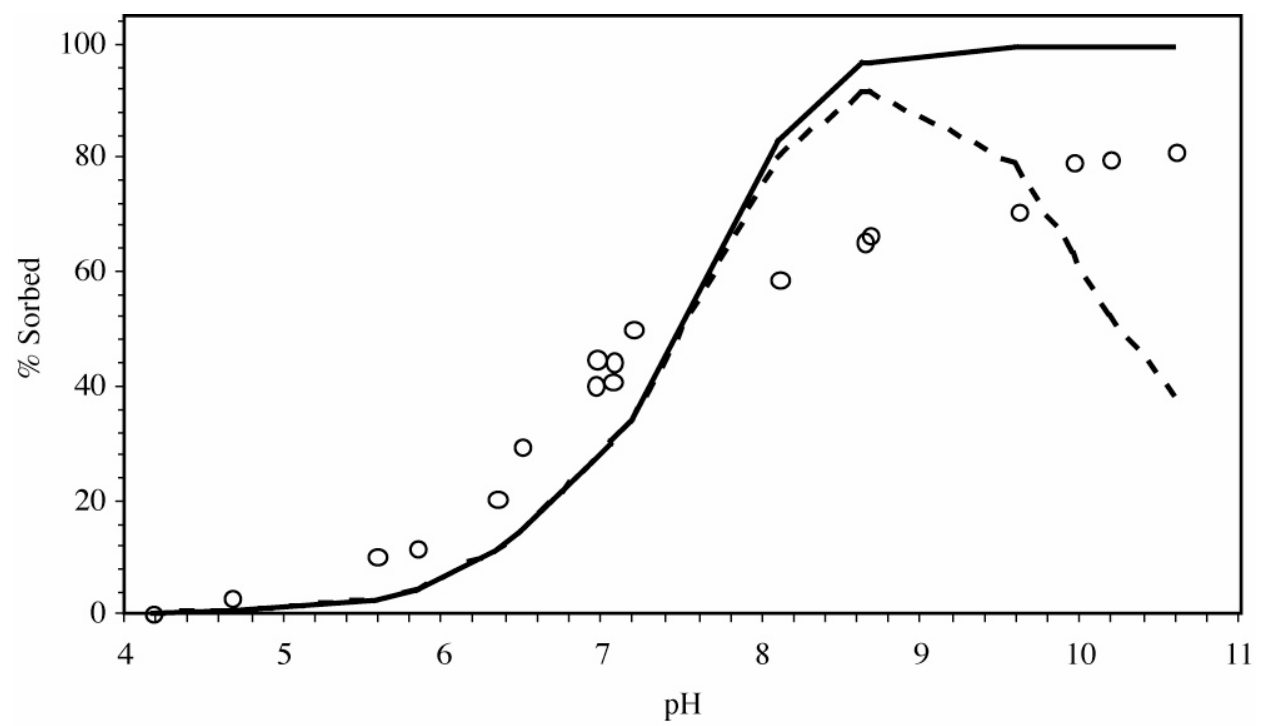

Figure 16. Sorption of $\mathrm{Np}(\mathrm{V})$ on natural FeOOH. Solid lines represent model prediction using NEM constants from Table 2 with total carbonate $\sim 5 \times 10^{-5} \mathrm{~mol} / \mathrm{L}$ (solid line) and $\mathrm{pCO}_{2}=3.5$ (dashed line). I $=0.1 ; 6 \times 10^{-6} \mathrm{~mol} / \mathrm{L} \mathrm{Np}(\mathrm{V}) ; 1 \mathrm{~g} / \mathrm{L} \mathrm{FeOOH} ; 15.7 \mathrm{~m}^{2} / \mathrm{g} \mathrm{FeOOH}$; open to air; data from Nakayama and Sakamoto (1991).

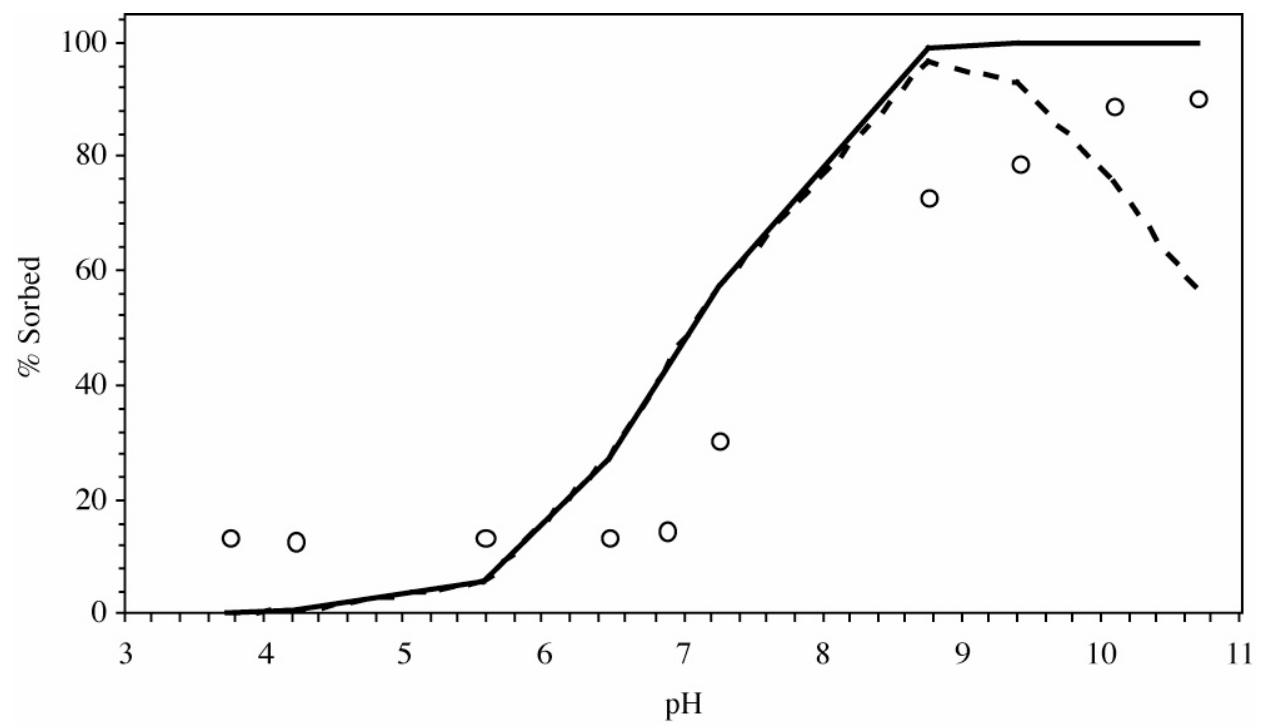

Figure 17. Sorption of $\mathrm{Np}(\mathrm{V})$ on synthetic $\gamma$-FeOOH. Solid lines represent model prediction using NEM constants from Table 2 with total carbonate $\sim 5 \times 10^{-5} \mathrm{~mol} / \mathrm{L}$ (solid line) and $\mathrm{pCO}_{2}=3.5$ (dashed line). $\mathrm{I}=0.1 ; 6 \times 10^{-6} \mathrm{~mol} / \mathrm{L} \mathrm{Np}(\mathrm{V}) ; 1 \mathrm{~g} / \mathrm{L} \mathrm{FeOOH} ; 15.7 \mathrm{~m}^{2} / \mathrm{g} \mathrm{FeOOH}$; open to air; data from Nakayama and Sakamoto (1991). 


\section{6 $\mathrm{Np}(\mathrm{V})$ on Calcite}

Single point sorption experiments of Keeney-Kennicutt and Morse (1984) were conducted as batch experiments in distilled water or seawater and at concentrations ranging from $10^{-15}$ to $10^{-10} \mathrm{~mol} / \mathrm{L} \mathrm{Np}(\mathrm{V})$. Given the 5 order of magnitude range in radionuclide concentration, the variation in fitted $\log K$ is rather small (average $\log K=$ $2.35 \pm 0.19)$. As in the $\mathrm{Am}(\mathrm{III})$ data, sorption was only measured at $\mathrm{pH} \sim 8$. The surface species chosen to represent $\mathrm{Np}(\mathrm{V})$ sorption on calcite was based on the assumption that the positively charged $\mathrm{NpO}_{2}^{+}$exchanges with $\mathrm{Ca}^{2+}$. However, the single $\mathrm{pH}$ data could be fit with any surface species.

In their investigation, Keeney-Kennicutt and Morse (1984) also examined the sorptive properties of several other minerals including $\mathrm{FeOOH}$. They found that, on a mineral surface area basis, calcite was a stronger sorber that $\mathrm{FeOOH}$. The information suggests that calcite can play a critical role in $\mathrm{Np}(\mathrm{V})$ retardation in areas where it is present in significant amounts.

Sorption envelope data for $\mathrm{Np}(\mathrm{V})$ on calcite in atmospheric $\mathrm{CO}_{2}(\mathrm{~g})$ equilibrated waters were collected for the UGTA program in FY2000. Details regarding this data were presented in an internal report attached here as Appendix A. The fit to these data is shown in Figure 18 and listed in Table 1. The fitted $\log K(1.46)$ is significantly lower than that based on the data of Keeney-Kennicutt and Morse (1984). However, if only the $\mathrm{pH} 8$ data were used from the sorption envelope, the fitted $\log K$ constant would be nearly the same. The data fit shown in Figure 18 seems to indicate that a more complex sorption model is necessary to accurately match the sorption data. This can also be observed in the $\mathrm{Eu}(\mathrm{III})$ and $\mathrm{Sm}(\mathrm{III})$ sorption data modeling reported in Appendix A. Van Cappellen et al. (1993) proposed a surface complexation model for the calcite surface that is more complex than the simplified surface exchange model used here and by authors such as Zachara (Cowan et al., 1990; Zachara et al., 1991; Zachara et al., 1993; Zachara et al., 1988). The Van Cappellen model includes both $>\mathrm{CO}_{3} \mathrm{H}$ and $>\mathrm{CaOH}$ surface species that undergo protonation, deprotonation, and cation/anion sorption. Using this model, we fit the sorption envelope data using $>\mathrm{CO}_{3} \mathrm{NpO}_{2}$ and $>\mathrm{CaCO}_{3} \mathrm{NpO}_{2}$ surface species; the fit result is shown in Figure 18. The fit results suggest that, for some radionuclides, a more complex model of sorption to the calcite surface may be necessary. However, for radionuclides such as $\operatorname{Sr}(\mathrm{II})$ and $\mathrm{U}(\mathrm{VI})$, a more complex model is not necessary. At present, we rely on the simpler one-site surface exchange model. The fit to the sorption envelope data is reported in Table 3. 


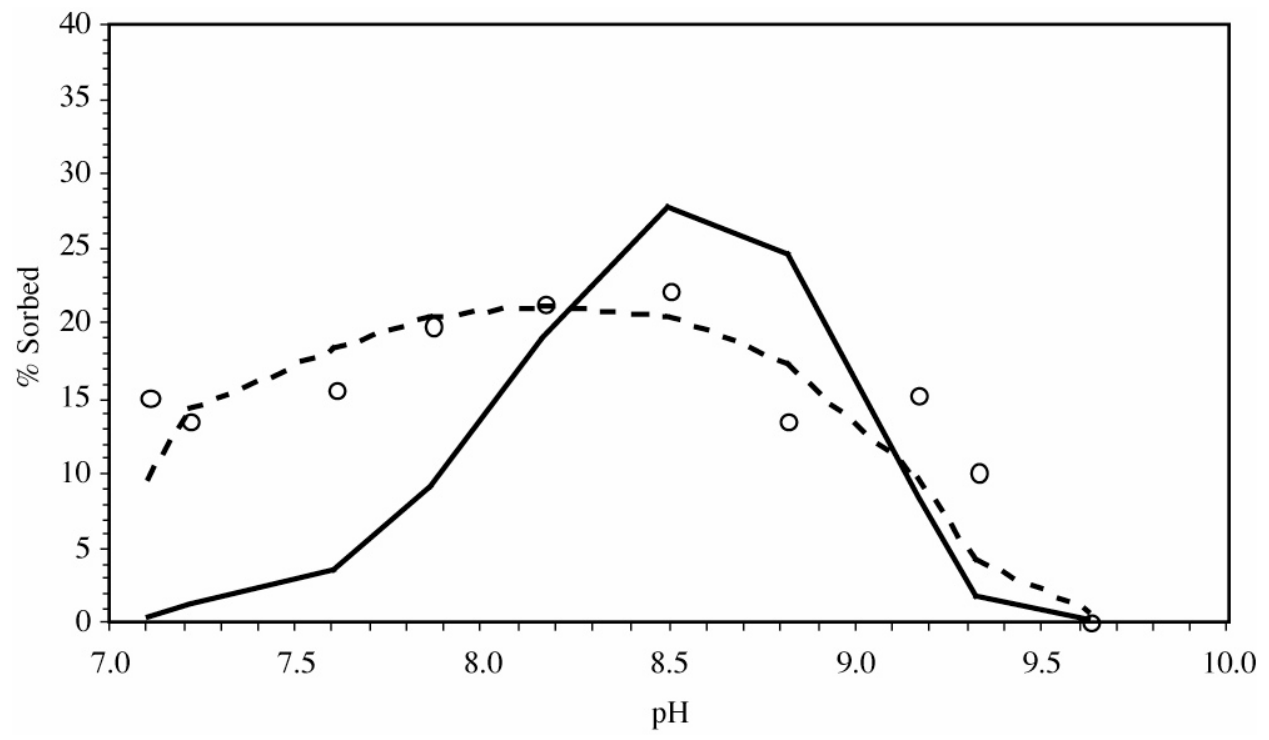

Figure 18. Sorption of $\mathrm{Np}(\mathrm{V})$ on calcite. Solid lines represent model prediction using NEM constants from Table 3. Dashed line represent fit based on the calcite surface model of Van Cappellen et al. (1993). I = $0.1 ; 6 \times 10^{-6} \mathrm{~mol} / \mathrm{L} \mathrm{Np(V);1} \mathrm{g/L} \mathrm{calcite;} 15.7 \mathrm{~m}^{2} / \mathrm{g}$ calcite; open to air; data from Appendix A.

\section{7 $\mathrm{Pu}(\mathrm{IV})$ and $\mathrm{Pu}(\mathrm{V})$ on Iron Oxide Minerals}

Sanchez et al. (1985) examined the sorption of Pu on FeOOH at two Pu oxidation states. Although thermodynamic calculations estimate that the $\mathrm{Pu}(\mathrm{V})($ or $\mathrm{Pu}(\mathrm{VI}))$ should be more stable than $\mathrm{Pu}(\mathrm{IV})$ at atmospheric conditions, Sanchez et al. (1985) observed that during the course of $\mathrm{Pu}(\mathrm{V})$ sorption experiments (hours to days), significant reduction occurred when $\mathrm{FeOOH}$ was present. Though no mechanisms could be determined, they hypothesized that the iron oxide surface promoted $\mathrm{Pu}(\mathrm{V})$ reduction either by catalyzing sorbed $\mathrm{Pu}(\mathrm{V})$ reduction or by increasing aqueous $\mathrm{Pu}(\mathrm{V})$ reduction rates due to strong $\mathrm{Pu}(\mathrm{IV})$ sorption. Keeney-Kennicutt and Morse (1985) made similar observations for $\mathrm{Pu}$ and determined that +4 was the dominant oxidation state of $\mathrm{Pu}$ on $\mathrm{FeOOH}$. This observation was not made for other minerals (e.g. $\mathrm{MnO}_{2}$, calcite, and aragonite). Regardless of the mechanism, the results indicated that $\mathrm{Pu}(\mathrm{IV})$ sorption under atmospheric conditions may be important in Pu transport.

$\mathrm{Pu}(\mathrm{IV})$ sorption experiments of Sanchez et al. (1985) were performed at $10^{-10}$ and $10^{-11}$ $\mathrm{mol} / \mathrm{L} \mathrm{Pu}$; two surface species were required to adequately describe sorption data (Figure 19). For $\mathrm{Pu}(\mathrm{V})$, sorption data measured after 1 hour of reaction were assumed to have negligible reduction effects and data were fit assuming only $\mathrm{Pu}(\mathrm{V})$ species. In the case of $\mathrm{Pu}(\mathrm{V})$, two surface species were also required to adequately fit sorption data (Figure 20). The difference between $\log K$ constants for the two $\mathrm{Pu}(\mathrm{IV})$ and two $\mathrm{Pu}(\mathrm{V})$ fits amounted 
to between 0.05 and $0.6 \mathrm{Log} K$ units. Average fits to the $\mathrm{Pu}(\mathrm{IV})$ and $\mathrm{Pu}(\mathrm{V})$ data are reported in Table 2.

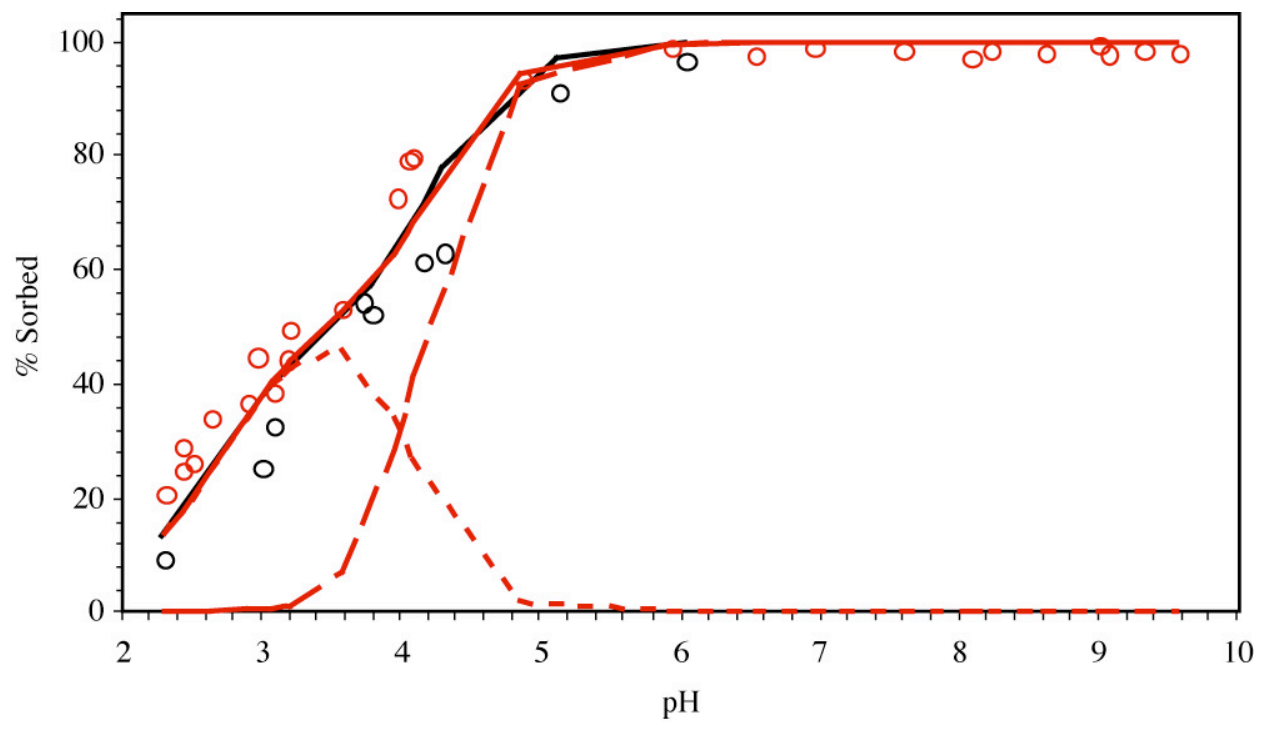

Figure 19. Sorption of $10^{-10}$ (black) and $10^{-11}$ (red) $\mathrm{mol} / \mathrm{L} \mathrm{Pu(IV)}$ on FeOOH. Solid lines represent model prediction using NEM constants from Table 2 . $I=0.1 ; 28.5 \mathrm{~m}^{2} / \mathrm{L}$ as FeOOH; data from Sanchez et al. (1985); dashed lines = individual species contributions.

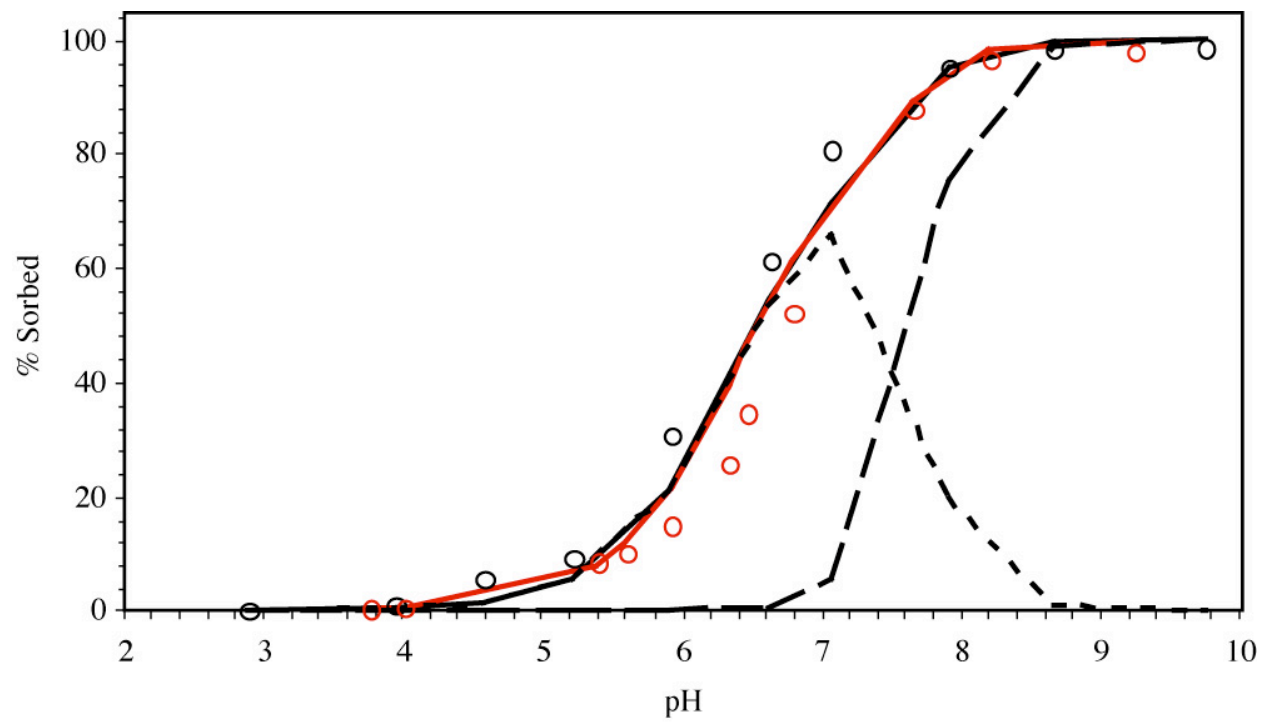

Figure 20. Sorption of $10^{-10}$ (black) and $10^{-11}$ (red) mol/L Pu(V) on FeOOH. Solid lines represent model prediction using NEM constants from Table 2 . I $=0.1 ; 28.5 \mathrm{~m}^{2} / \mathrm{L}$ as FeOOH; data from Sanchez et al. (1985); dashed lines = individual species contributions. 


\section{8 $\mathrm{Pu}(\mathrm{IV})$ and $\mathrm{Pu}(\mathrm{V})$ on Calcite}

Several investigators have examined the interaction of Pu with calcite (Ginzburg and Maksimov, 1975; Keeney-Kennicutt and Morse, 1985; Meece and Benninger, 1993) though their data yield largely qualitative sorption information. Ginzburg and Maksimov (1975) noted that $\mathrm{Pu}(\mathrm{IV})$ easily coprecipitated with calcite resulting in a drastic decrease in aqueous $\mathrm{Pu}$ concentration. Meece and Benninger (1993) examined the interaction of $\mathrm{Pu}(\mathrm{IV})$ and $\mathrm{Pu}(\mathrm{VI})$ with calcite and determined that the more reduced state of $\mathrm{Pu}$ sorbed much more strongly. Pu(IV) sorption to calcite was not fit because the information available was not sufficient to determine a SC constant.

Keeney-Kennicutt and Morse (1985) examined the sorption of $\mathrm{Pu}(\mathrm{V})$ on calcite and determined that $\mathrm{Pu}(\mathrm{V})$ sorbs to carbonate minerals at nearly the same level (on a surface area basis) as $\mathrm{Pu}(\mathrm{V})$ on iron oxide. The results of Kenney-Kennicutt and Morse (1985) could be used to determine a $\log K$ constant at $\mathrm{pH} \sim 8$. The average fit to the data of Keeney-Kennicutt and Morse (1985) resulted in a Log $K$ constant of 1.85 \pm 0.35 .

Recent efforts by the UGTA project have yielded sorption data for $\mathrm{Pu}(\mathrm{IV})$ and $\mathrm{Pu}(\mathrm{V})$ on calcite. Fits to these data are listed in Table 1 while the data are presented in Appendix B. The $\log K$ constant for $\mathrm{Pu}(\mathrm{V})$ (1.63) is slightly lower than that predicted based on fits to the data of Keeney-Kennicutt and Morse (1985). This was also observed when comparing the $\mathrm{Np}(\mathrm{V})$ single $\mathrm{pH}$ data of Keeney-Kennicutt and Morse (1984) with the sorption envelope data of Appendix A. The Log $K$ constants for $\mathrm{Pu}(\mathrm{IV})$ and $\mathrm{Pu}(\mathrm{V})$ based on fits to the $\mathrm{pH}$ envelope data are reported in Table 3.

\section{9 $\mathrm{Sm}(\mathrm{III})$ on Calcite}

Zhong and Mucci (1995) performed sorption and coprecipitation experiments using a cocktail of 12 rare earth elements (including Sm(III)) at relatively high concentrations (single $\mathrm{pH}$ data). In fitting the data, it was assumed that there was no significant competition for surface sites between the various rare earth elements. Thus, fitted NEM constants are likely to be low. Comparison of sorption and coprecipitation fitting results indicate that the Doerner-Hoskins extrapolation of coprecipitation to sorption was in reasonable agreement (see discussion in Section 4). Note also that the fitted Log $K$ constants of Sm(III) and Eu(III) based on the data of Zhong and Mucci (1995) are nearly identical; this is consistent with other published data suggesting the rare earth elements behave similarly (Koeppenkastrop and Decarlo, 1992; Zhong and Mucci, 1995).

Sorption envelope data for $\mathrm{Sm}(\mathrm{III})$ on calcite in atmospheric $\mathrm{CO}_{2}(\mathrm{~g})$ equilibrated waters were collected for the UGTA project in FY2000. Details were presented in an internal report attached here as Appendix A. The resulting fitted Log $K$ constant is listed in Table 1 and is significantly greater than that based on the data of Zhong and Mucci (1995). This was expected given their experimental conditions. The Log $K$ constant based on the sorption envelope data (4.62) is reported in Table 2. However, this value is somewhat higher than that determined for Eu(III) (4.14). Due to the slightly soluble nature of 
calcite, measuring sorption is inherently difficult. Slight changes in solution $\mathrm{pH}$ or other solution conditions could initiate calcite dissolution or precipitation. This could dramatically affect sorption results (and the fitted reaction constants). Interestingly, $\mathrm{Sm}$ (III) and $\mathrm{Eu}(\mathrm{III})$ sorption at 30 days is quite similar (Appendix A). The behavior of $\mathrm{Sm}(\mathrm{III})$ and $\mathrm{Eu}(\mathrm{III})$ at the calcite-water interface appears to be similar, particularly when their behavior is integrated over time.

It should be noted that the sorption data for $\mathrm{Sm}(\mathrm{III})$ and $\mathrm{Eu}(\mathrm{III})$ are quite limited. The difference between $\log K$ constants of $\mathrm{Sm}(\mathrm{III})$ and $\mathrm{Eu}(\mathrm{III})$ based on the 1 day sorption envelope data of Appendix A suggests significant uncertainty in these values. However, these data provide significantly more detail regarding REE behavior than the single $\mathrm{pH}$ data reported by Zhong and Mucci (1995).

\subsection{0 $\mathrm{Sr}(\mathrm{II})$ on Iron Oxide Minerals}

Sr(II) sorption to iron oxide minerals was investigated by Kinniburgh et al. (1975). Batch sorption experiments were performed using freshly prepared $\mathrm{Fe}(\mathrm{OH})_{3}$ gel and $2 \times 10^{-6}$ $\mathrm{mol} / \mathrm{L} \mathrm{Sr}$ (II) in $1 \mathrm{~mol} / \mathrm{L} \mathrm{NaNO}_{3}$ solutions (Figure 21). Because the ionic strength of this solution was high and the activity correction model used in the data fitting was the Davies equation, there is some intrinsic error in our model (Figure 22). The Davies equation is typically considered accurate to an ionic strength of 0.1 . Models such as the extended Debye-Huckel model (Appendix C) can be accurate to ionic strengths of 1 or higher. Comparison of the $\mathrm{Sr}^{2+}$ activity coefficient as a function of ionic strength $\left(\mathrm{NaNO}_{3}\right.$ background electrolyte) using these two activity correction models suggests that the activity of $\mathrm{Sr}^{2+}$ in sorption solutions was underestimated during sorption modeling. As a results, NEM constants are expected to be artificially high. A similar fitting error was encountered when fitting the data of Kolarik (1962) (discussed below). Based on the activity correction at an ionic strength of 1 (Figure 22), we expect the $\mathrm{Sr}^{2+} \log K$ s reported in Tables 1 and 2 to overestimated by approximately 0.3 . However, this correction factor was not applied to these data.

The three surface species used by Dzombak and Morel (1990) were used to fit the data. The Log $K$ constants determined for the NEM were very different from the diffuse layer 2-site model data fit of Dzombak and Morel (1990) (2.16, -5.20, and -14.02 versus 5.01 ${ }^{\mathrm{s}}$, $-6.58^{\mathrm{w}}$, and $-17.6^{\mathrm{w}}$, respectively, where $\mathrm{s}$ and $\mathrm{w}$ indicate strong-site and weak-site sorption constants). Nevertheless, the additional complexity of the diffuse layer two-site model did not significantly improve the fit when compared to the NEM. 


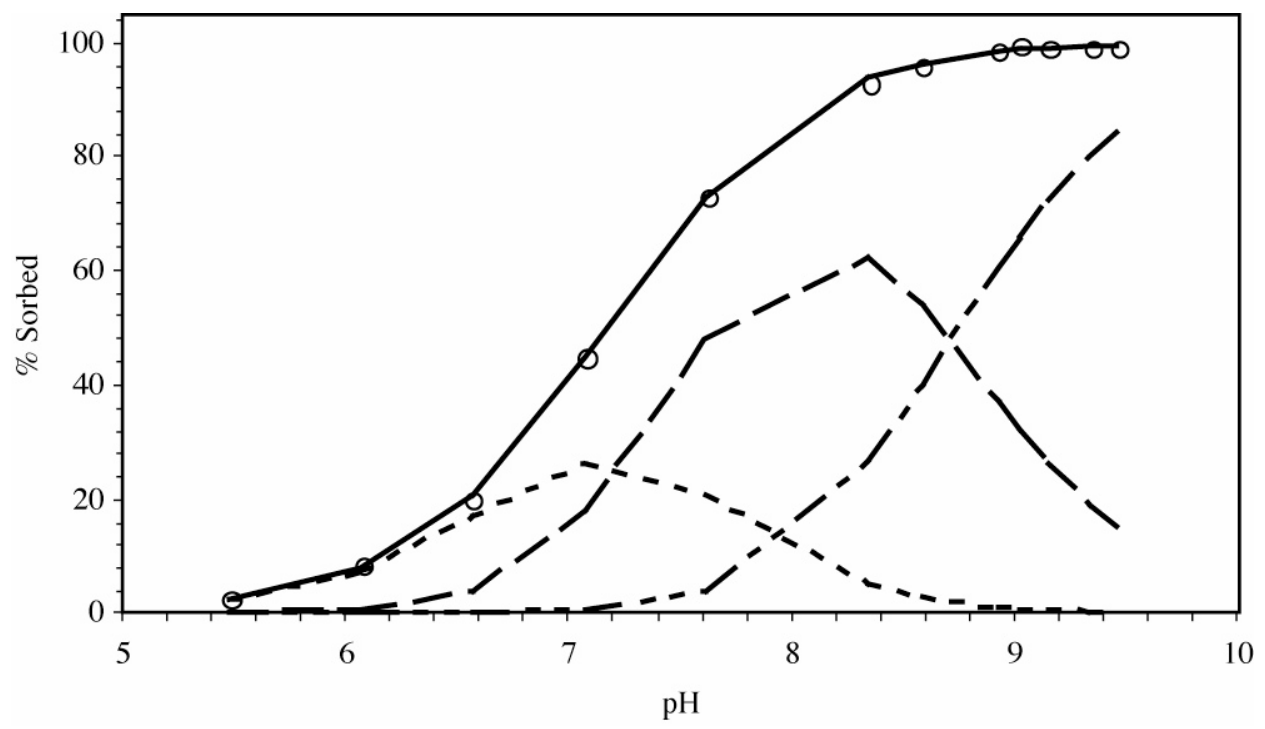

Figure 21. Sorption of $\mathrm{Sr}(\mathrm{II})$ on $\mathrm{Fe}(\mathrm{OH})_{3}$. Solid lines represent model prediction using NEM constants from Table 3. I $=1 ; 2 \times 10^{-6} \mathrm{~mol} / \mathrm{L} \mathrm{Sr}(\mathrm{II}) ; 9.24 \times 10^{-2} \mathrm{~mol} / \mathrm{L} \mathrm{Fe}$ as $\mathrm{Fe}(\mathrm{OH})_{3}$; open to air; data from Kinniburgh et al. (1975); dashed lines = individual species contributions.

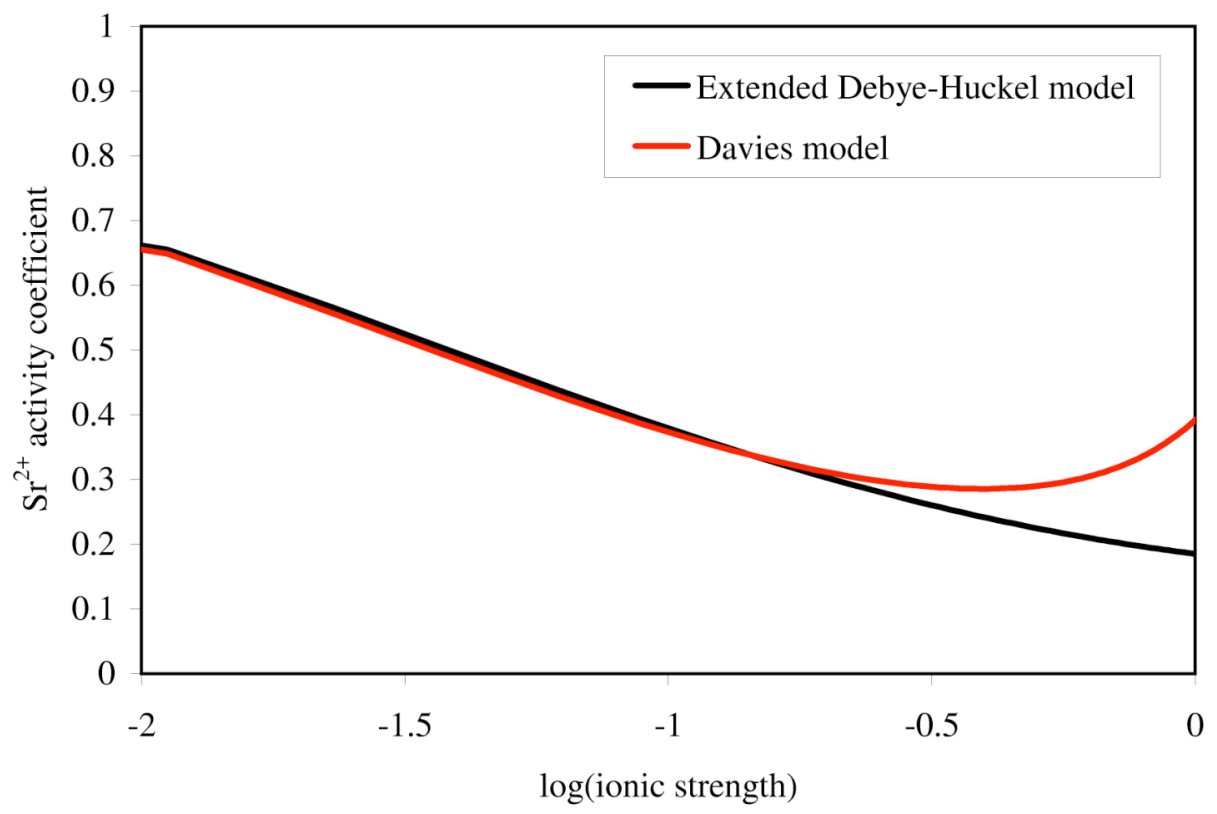

Figure 22. Comparison of $\mathrm{Sr}^{2+}$ activity coefficient as a function of ionic strength using the Davies model and the Extended Debye-Huckel model. 
Sr(II) sorption to iron oxide minerals was also investigated by Kolarik (1961). The data shown here were reproduced from the sorption compilation of Dzombak and Morel (1990). This data set includes sorption of $10^{-7}$ to $10^{-2} \mathrm{~mol} / \mathrm{L} \mathrm{Sr}$ (II) on $2 \times 10^{-2}$ to $2 \times 10^{-1}$ $\mathrm{mol} / \mathrm{L} \mathrm{Fe}$ as hydrous ferric oxide. All sorption experiments were performed in $1 \mathrm{~mol} / \mathrm{L}$ $\mathrm{NaNO}_{3}$ background electrolyte. Data fits are reported in Table 1. Data and model predictions using NEM constants from Table 2 are shown in Figures 23 and 24. At low surface loads, one-site NEM fits to the data of Kinniburgh et al. (1975) are good. When Sr(II) surface loads are greater than $5 \%$ of maximum, the one-site model is inadequate. This is consistent with high affinity site densities of $5 \%$. Because the change in surface affinity for $\mathrm{Sr}$ (II) occurs only at high aqueous $\mathrm{Sr}$ (II) concentrations (which are not present at NTS), Sr(II) sorption is likely to be controlled by high-affinity sorption at the NTS. For example, $\operatorname{Sr}(\mathrm{II})$ concentrations at the Cambric site, NTS, were found to be $\sim 10^{-5}$ $\mathrm{mol} / \mathrm{L}$ (dominated by natural background $\mathrm{Sr}(\mathrm{II})$ that is not radioactive) (Tompson et al., 1999). Batch saturation extracts of alluvial sediments from the U-1a tunnel complex, NTS, were found to have $\operatorname{Sr}(\mathrm{II})$ concentrations in this range as well. To retain the simplified one-site NEM approach, Log $K$ constants fitted to the three high surface load data sets were not used in calculating the average NEM constants reported in Table 2. The average Log $K$ constants, based on the data of Kinniburgh et al. (1975) and the low surface load data of Kolarik (1961), are 2.22 $\pm 0.13,-5.30 \pm 0.31$, and $-14.14 \pm 0.40$ for $>\mathrm{FeOHSr}^{2+},>\mathrm{FeOSr}^{+}$, and $>\mathrm{FeOSrOH}$, respectively.

These results illustrate a limitation to our simplified one-site NEM model. In the present configuration, the applicability of these constants is limited and caution must be used in extrapolating Log $K$ constants beyond the surface loads and ion strengths examined. In general, extrapolation to lower surface loads is less problematic and will typically result in conservative estimates of radionuclide migration. 


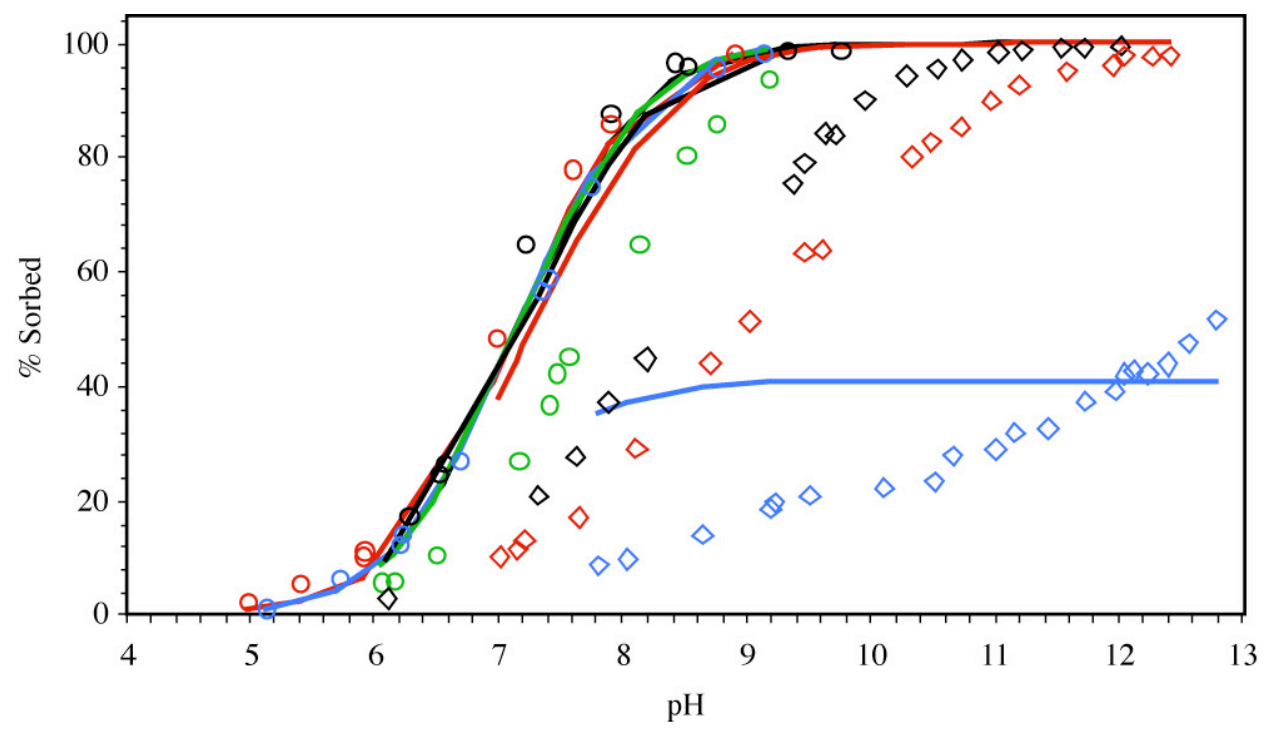

Figure 23. Sorption of $10^{-7}$ (black circle), $8.34 \times 10^{-6}$ (red circle), $8.34 \times 10^{-5}$ (blue circle), $10^{-3}$ (green circle), $5 \times 10^{-3}$ (black diamond), $10^{-2}$ (red diamond), and $5 \times 10^{-2}$ (blue diamond) $\mathrm{mol} / \mathrm{L} \mathrm{Sr}$ (II) on $\mathrm{Fe}(\mathrm{OH})_{3}$. Solid lines represent model prediction using NEM constants from Table 2 . $\mathrm{I}=1 ; 10^{-1} \mathrm{~mol} / \mathrm{L}$ $\mathrm{Fe}$ as $\mathrm{Fe}(\mathrm{OH})_{3}$; open to air; data from Kolarik (1961).

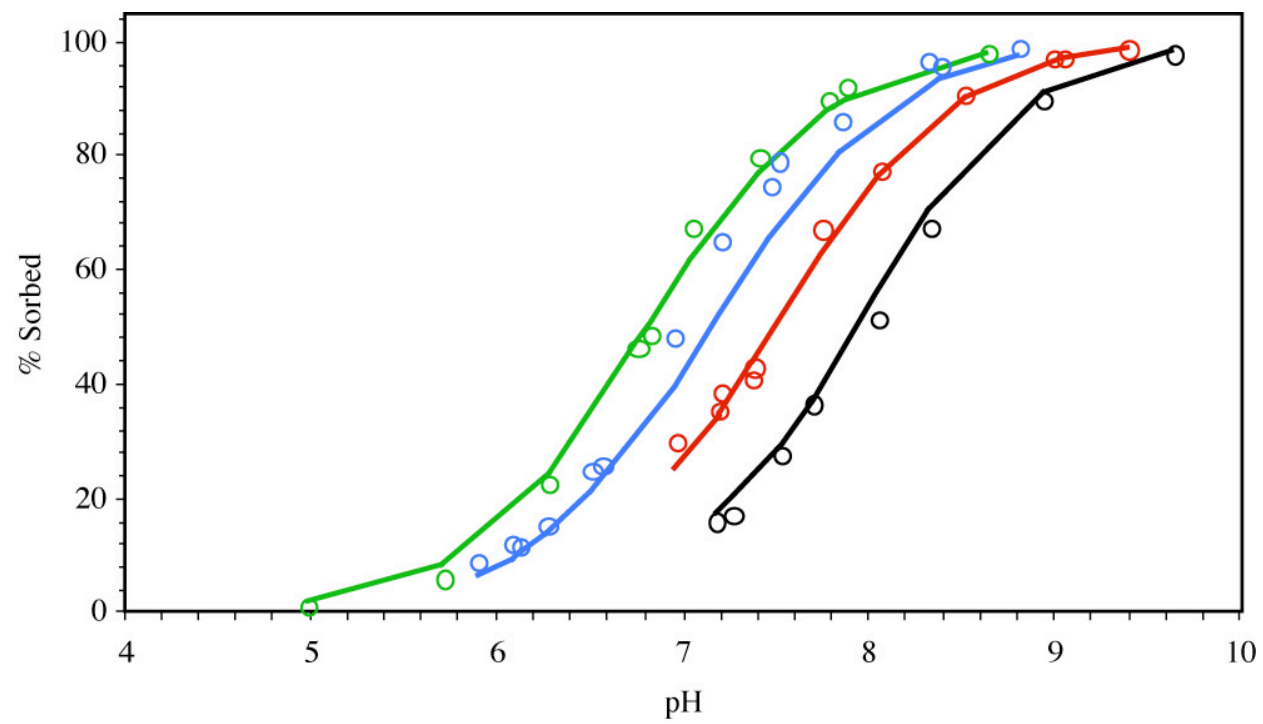

Figure 24. Sorption of Sr(II) on $2 \times 10^{-2}$ (black), $5 \times 10^{-2}$ (red), $10^{-1}$ (blue), and $2 \times 10^{-1}$ (green) $\mathrm{mol} / \mathrm{L} \mathrm{Fe}$ as $\mathrm{Fe}(\mathrm{OH})_{3}$. Solid lines represent model prediction using NEM constants from Table $2 . \mathrm{I}=1 ; \mathbf{1 0}^{-7}$ $\mathrm{mol} / \mathrm{L} \mathrm{Sr}$ (II); open to air; data from Kolarik (1961). 


\subsection{Sr(II) on Calcite}

Zachara et al. (1991) determined that $\operatorname{Sr}($ II) does not partition to calcite surfaces very strongly (Figure 25). Their experiments were run with well crystallized and aged calcite; this tended to minimized recrystallization, precipitation, and dissolution effects. The Log $K$ constant determined from this data is -1.75 (Table 1). Doner and Zavarin (1997) reviewed $\mathrm{Sr}$ (II) sorption and coprecipitation data from various investigators (Mucci and Morse, 1983; Pingitore, 1986; Pingitore and Eastman, 1986; Zachara et al., 1991) and estimated $\log K$ to be -0.89 . In general, calcite partitioning constants have been observed to approach 1.0 with increasing precipitation rate ${ }^{6}$. Thus, coprecipitation $\log K$ constants are generally closer to 1.0 than sorption $\log K$ constants. For $\operatorname{Sr}(I I)$ on calcite, the sorption $\log K$ constant is less than 1.0. Thus, $\log K$ constants determined from coprecipitation data are likely to be greater that sorption constants (as a result of nonequilibrium surface partitioning during calcite precipitation). A similar effect should be observed when sorption $\log K$ constants are greater than 1 . In that case, coprecipitation Log $K$ constants should be lower than sorption Log $K$ constants. This was, in fact, observed for $\mathrm{Sm}(\mathrm{III})$ and $\mathrm{Eu}(\mathrm{III})$ data described earlier. The surface complexation constant based on the NEM fit to data of Zachara et al. (1991) is reported inTable 3.

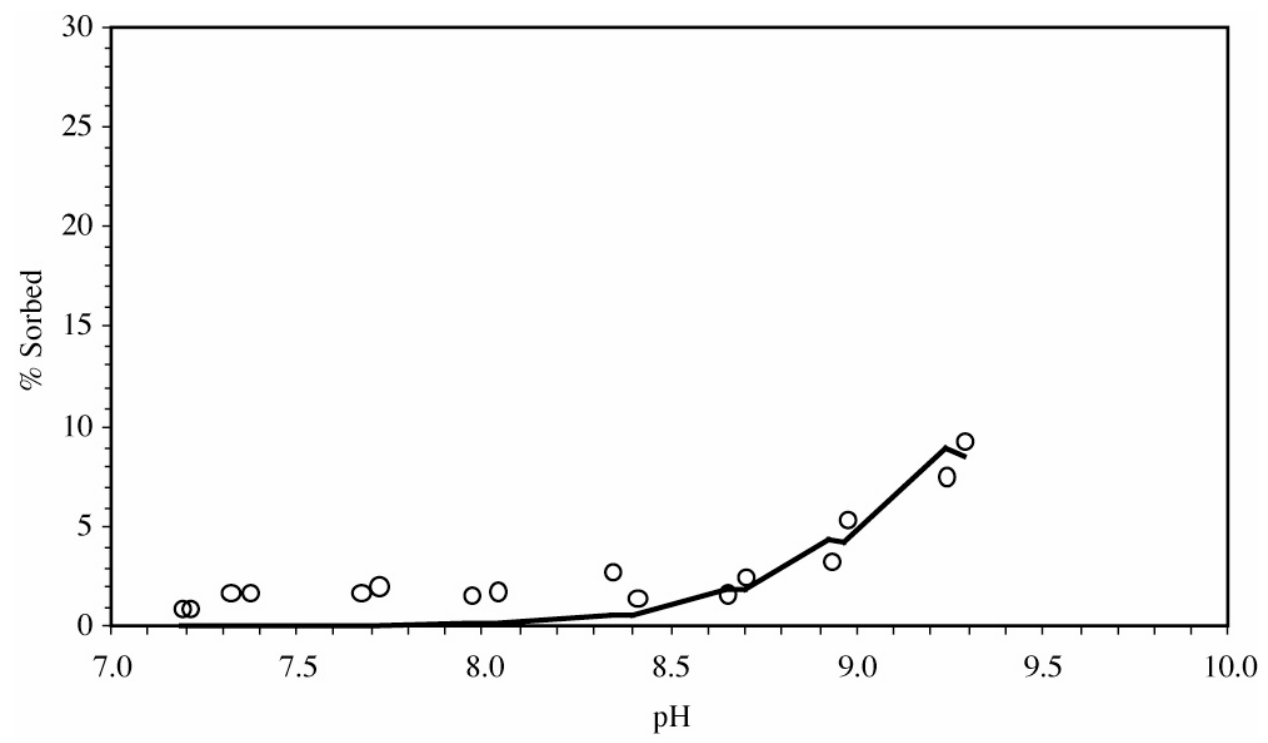

Figure 25. Sorption of $\mathrm{Sr}(\mathrm{II})$ on $\mathrm{CaCO}_{3}$. Solid lines represent model prediction using NEM constants from Table 3. $\mathrm{I}=0.1 ; 10^{-7} \mathrm{~mol} / \mathrm{L} \mathrm{Sr}(\mathrm{II}) ; 25 \mathrm{~g} / \mathrm{L} \mathrm{CaCO}_{3} ; 3.6 \times 10^{-6} \mathrm{~mol}$ sites/g; open to air; data from Zachara et al. (1991).

\footnotetext{
${ }^{6}$ Strictly, this is the case when partitioning constants are defined in terms of total aqueous component concentration instead of single species activity.
} 


\subsection{U(VI) on Iron Oxide Minerals}

A rather large set of data on $\mathrm{U}(\mathrm{VI})$ sorption to iron oxide minerals is available in the literature (Table 1 and Figures 26 to 32). Though the majority of fits were used to calculate the average NEM constants reported in Table 2, several were omitted. Results were not used either when incomplete information was available on experimental conditions or when the particular surface species did not contribute significantly to the fit. For example, two data sets from Hsi and Langmuir (1985) were not used because total carbonate in solution was poorly controlled in their experiments. Since U(VI) complexation with $\mathrm{CO}_{3}{ }^{2-}$ in solution can significantly alter sorption results (as shown in data of Duff and Amrhein (1996), Figure 32), only those data sets with good control over carbonate concentrations were reliable. In the data sets of Hsi and Langmuir (1985) for $\mathrm{U}(\mathrm{VI})$ on $\mathrm{Fe}_{2} \mathrm{O}_{3}$ (Figure 27), the contribution of the $>\mathrm{FeOHUO}_{2}{ }^{2+}$ species to total sorption was minimal because this species contributed to sorption only at low $\mathrm{pH}$. In that case, the fit to that surface species. was not used to calculate the NEM average. The average NEM constants reported in Table 2 for $>\mathrm{FeOHUO}_{3}$ and $>\mathrm{FeOHUO}_{2}{ }^{2+}$ species are $-3.05 \pm 0.43$ and $6.63 \pm 0.54$, respectively. Given the 4 order of magnitude range in $U$ concentration, the use of both natural and synthetic hematite, goethite, and hydrous ferric oxide minerals, and $\mathrm{CO}_{2}$ partial pressures of 0 to $90 \%$, the one-site NEM was able to predict sorption quite well. As discussed earlier, the results of the fit also indicate that the onesite NEM could, in some cases, fit a robust set of data with large variations in experimental conditions. When all data fits are used, the $\log K$ averages are $-2.88 \pm 0.56$ and $6.77 \pm 0.50$ for $>\mathrm{FeOHUO}_{3}$ and $>\mathrm{FeOHUO}_{2}{ }^{2+}$, respectively. These values are, in fact, not significantly different from the average NEM constants listed in Table 2. However, the standard deviations are larger. 


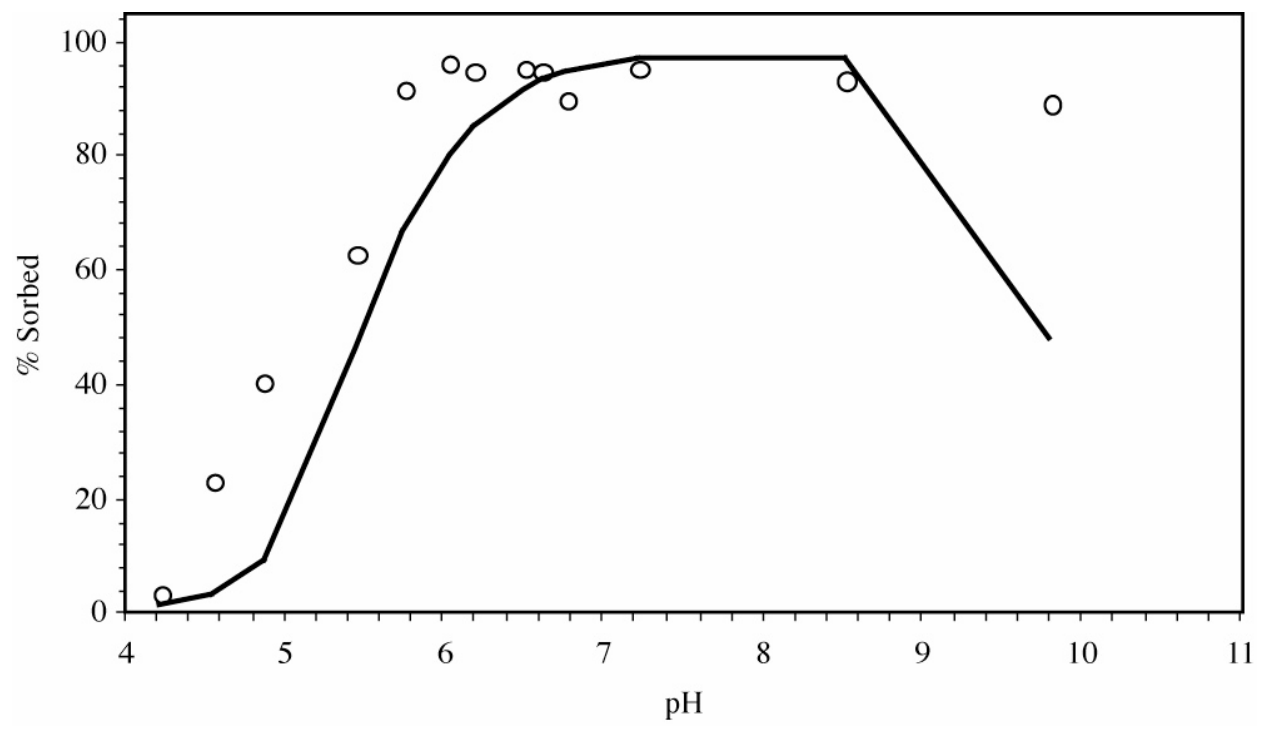

Figure 26. Sorption of $\mathrm{U}(\mathrm{VI})$ on $\mathrm{Fe}_{2} \mathrm{O}_{3}$ (no $\mathrm{CO}_{2}(\mathrm{~g})$ ). Solid lines represent model prediction using NEM constants from Table 2. I $=0.01 ; \mathrm{U}(\mathrm{VI})=2 \times 10^{-6} \mathrm{~mol} / \mathrm{L} ; 1 \mathrm{~g} / \mathrm{L} \mathrm{Fe}_{2} \mathrm{O}_{3} ;$ and $1.5 \mathrm{~m}^{2} / \mathrm{g} \mathrm{Fe}_{2} \mathrm{O}_{3}$; data from Viani and Torretto (1998).

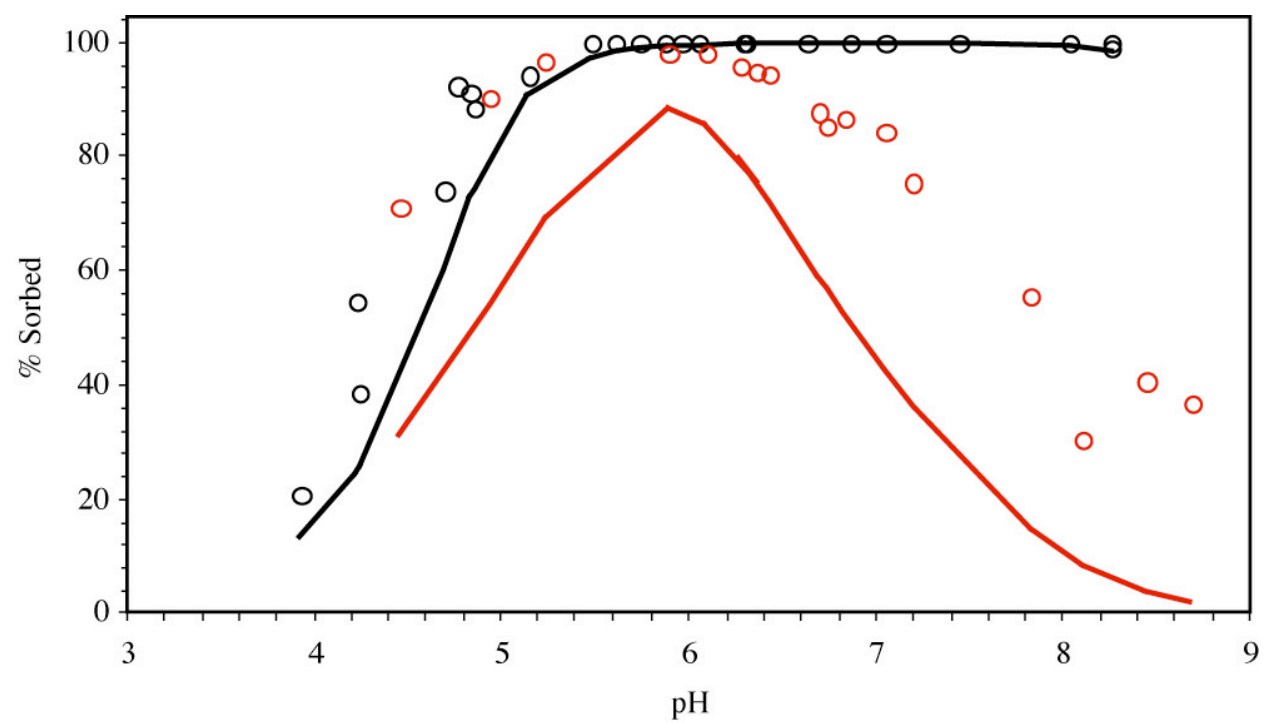

Figure 27. Sorption of U(VI) on FeOOH at $10^{-3}$ (black) and $10^{-2}$ (red) mol/L total carbonate . Solid lines represent model prediction using NEM constants from Table 2 . $\mathrm{I}=0.1 ; 10^{-5} \mathrm{~mol} / \mathrm{L} \mathrm{U}(\mathrm{VI}) ; 1 \mathrm{~g} / \mathrm{L}$ $\mathrm{FeOOH} ; 50 \mathrm{~m}^{2} / \mathrm{g} \mathrm{FeOOH}$; data from Hsi and Langmuir (1985). 


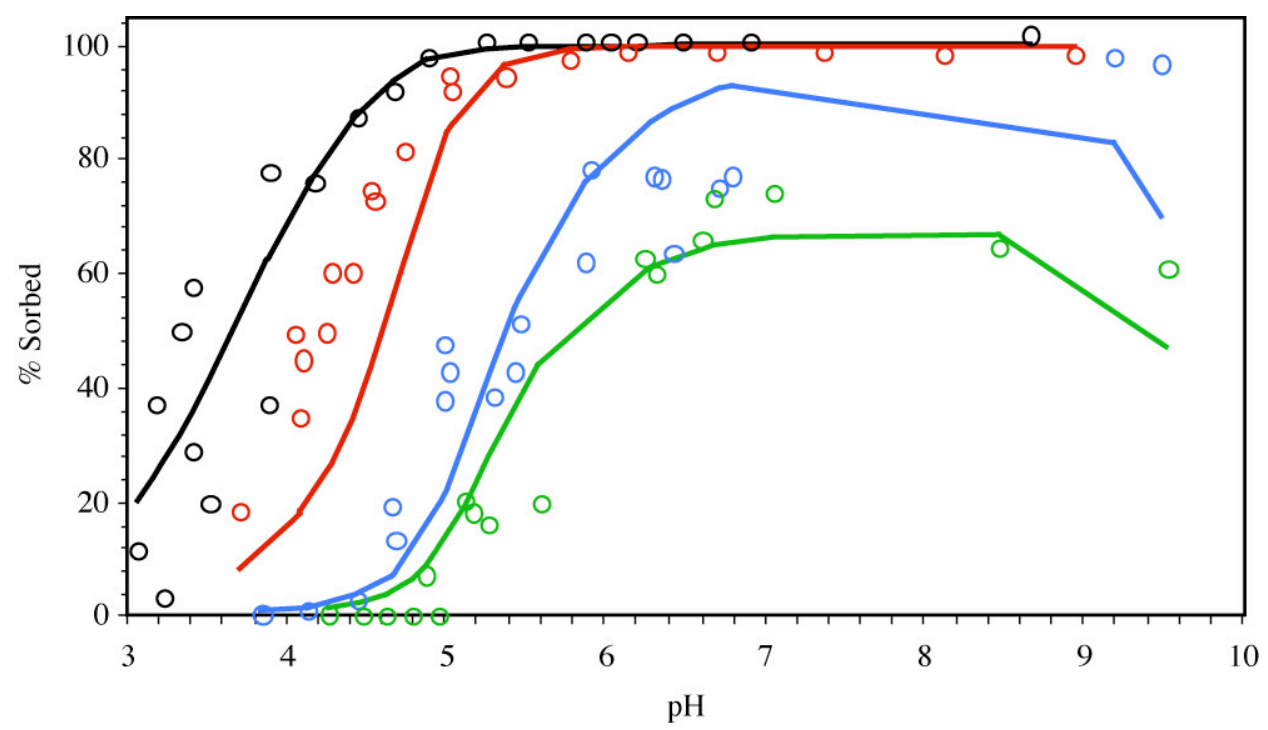

Figure 28. Sorption of $\mathrm{U}(\mathrm{VI})$ on $\mathrm{Fe}(\mathrm{OH})_{3}$ (black), $\mathrm{FeOOH}$ (red), synthetic $\mathrm{Fe}_{2} \mathrm{O}_{3}$ (blue), and natural $\mathrm{Fe}_{2} \mathrm{O}_{3}$ (green). Solid lines represent model prediction using NEM constants from Table 2. $\mathrm{I}=0.1$;

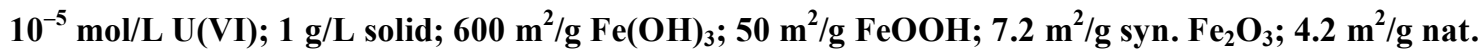
$\mathrm{Fe}_{2} \mathrm{O}_{3}$; data from Hsi and Langmuir (1985).

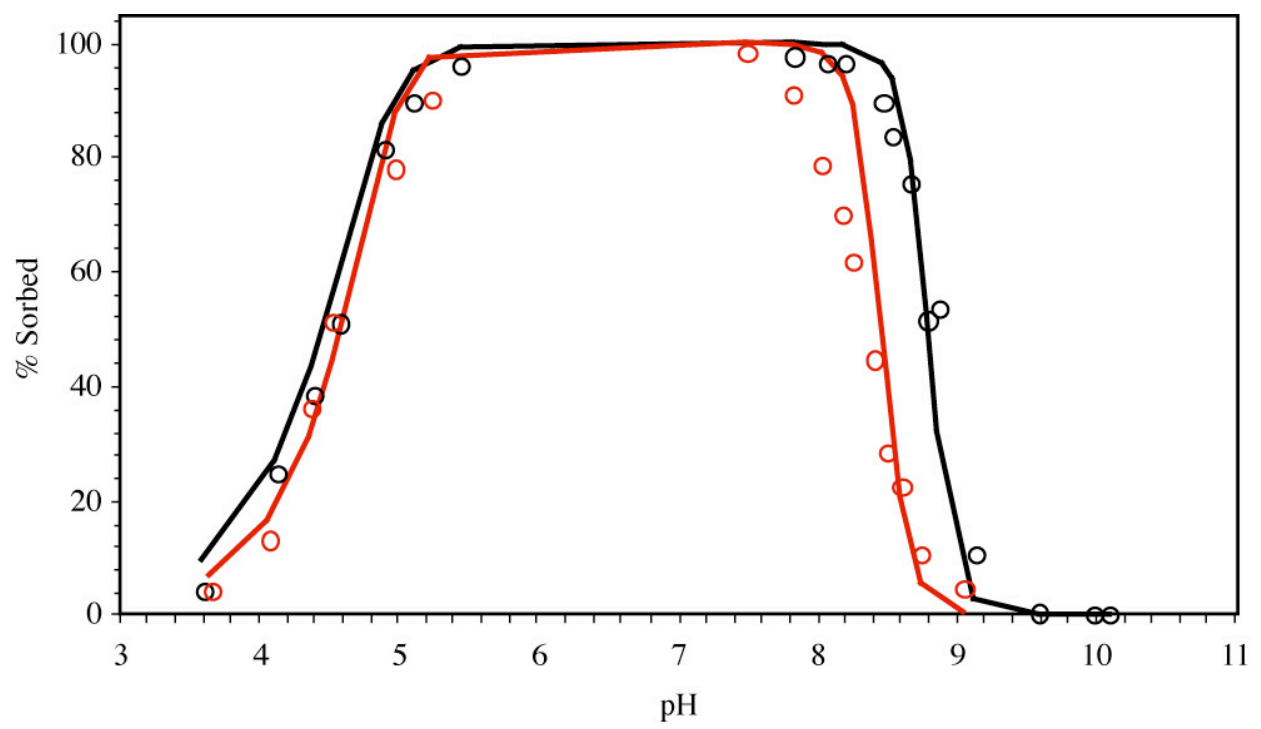

Figure 29. Sorption of $\mathrm{U}(\mathrm{VI})$ on $\mathrm{Fe}(\mathrm{OH})_{3}$ at $\mathrm{I}=0.02$ (black) and $\mathrm{I}=0.5$ (red). Solid lines represent model prediction using NEM constants from Table 2 . $\mathrm{U}(\mathrm{VI})=10^{-6} \mathrm{~mol} / \mathrm{L} ; 10^{-3} \mathrm{~mol} / \mathrm{L} \mathrm{Fe}$ as $\mathrm{Fe}(\mathrm{OH})_{3}$; open to air; data from Waite et al. (1994). 


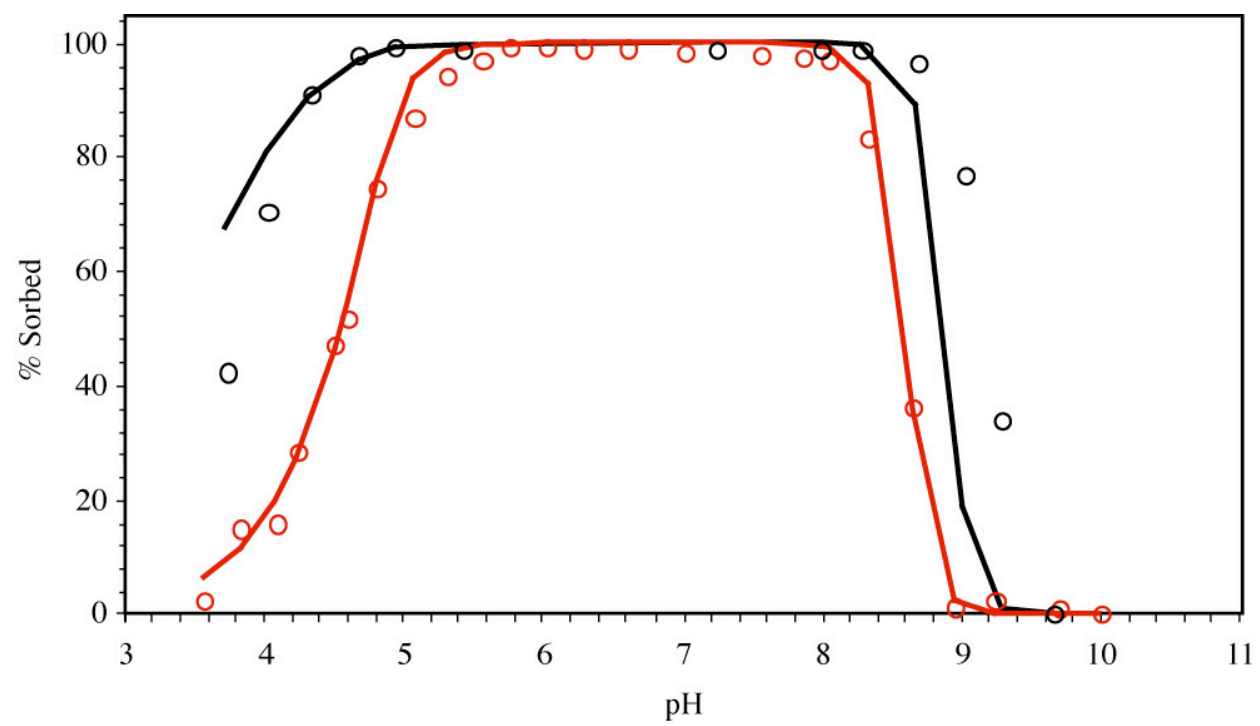

Figure 30. Sorption of $\mathrm{U}(\mathrm{VI})$ on $\mathrm{Fe}(\mathrm{OH})_{3}$ at 0.02 (black) and 0.001 (red) $\mathrm{mol} / \mathrm{L} \mathrm{Fe}$ as $\mathrm{Fe}(\mathrm{OH})_{3}$. Solid lines represent model prediction using NEM constants from Table $2 . \quad \mathrm{I}=0.1 ; 10^{-6} \mathrm{~mol} / \mathrm{L} \mathrm{U}(\mathrm{VI})$; open to air; data from Waite et al. (1994).

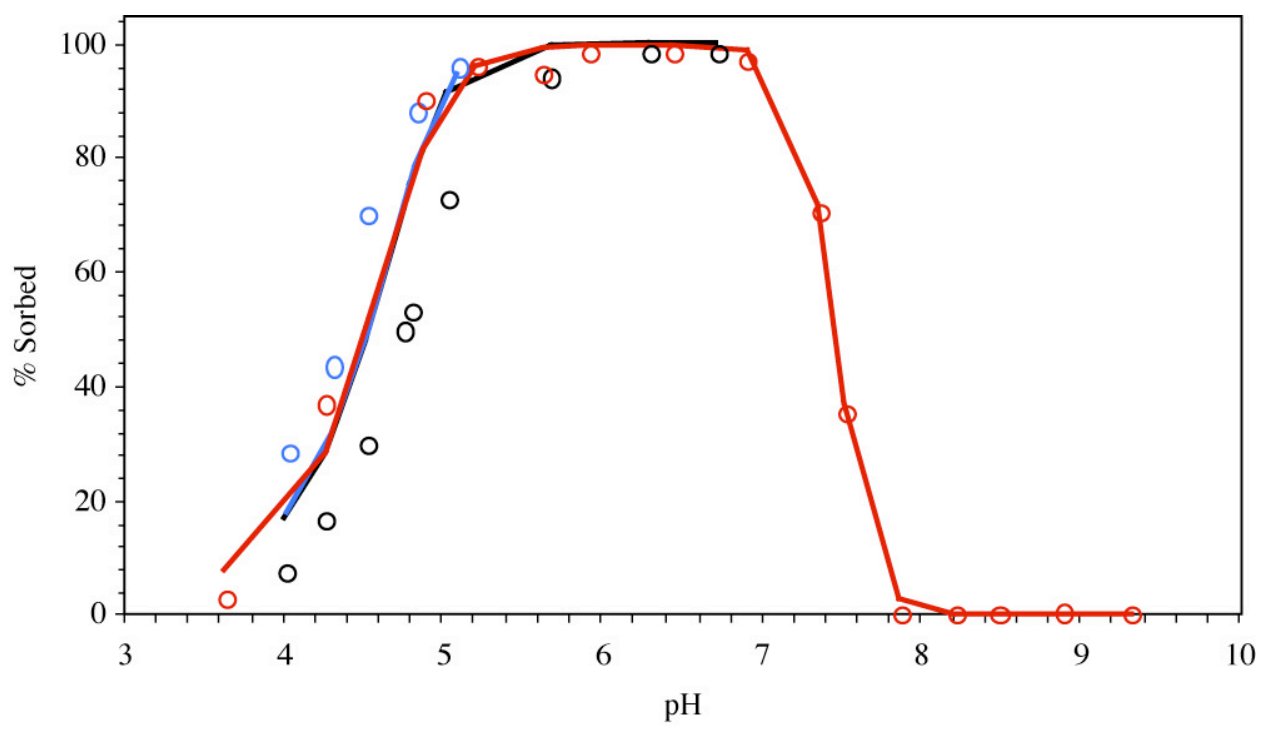

Figure 31. Sorption of $10^{-5}$ (black), $10^{-6}$ (red), and $10^{-8}$ (blue) mol/L U(VI) on $\mathrm{Fe}(\mathrm{OH})_{3}$. Solid lines represent model prediction using NEM constants from Table 2 . $I=0.1 ; 10^{-3} \mathrm{~mol} / \mathrm{L} \mathrm{Fe}$ as $\mathrm{Fe}(\mathrm{OH})_{3}$; open to air (except $10^{-6} \mathrm{~mol} / \mathrm{L} \mathrm{U}(\mathrm{VI})$ samples at $1 \% \mathrm{CO}_{2}(\mathrm{~g})$ ); data from Waite et al. (1994). 


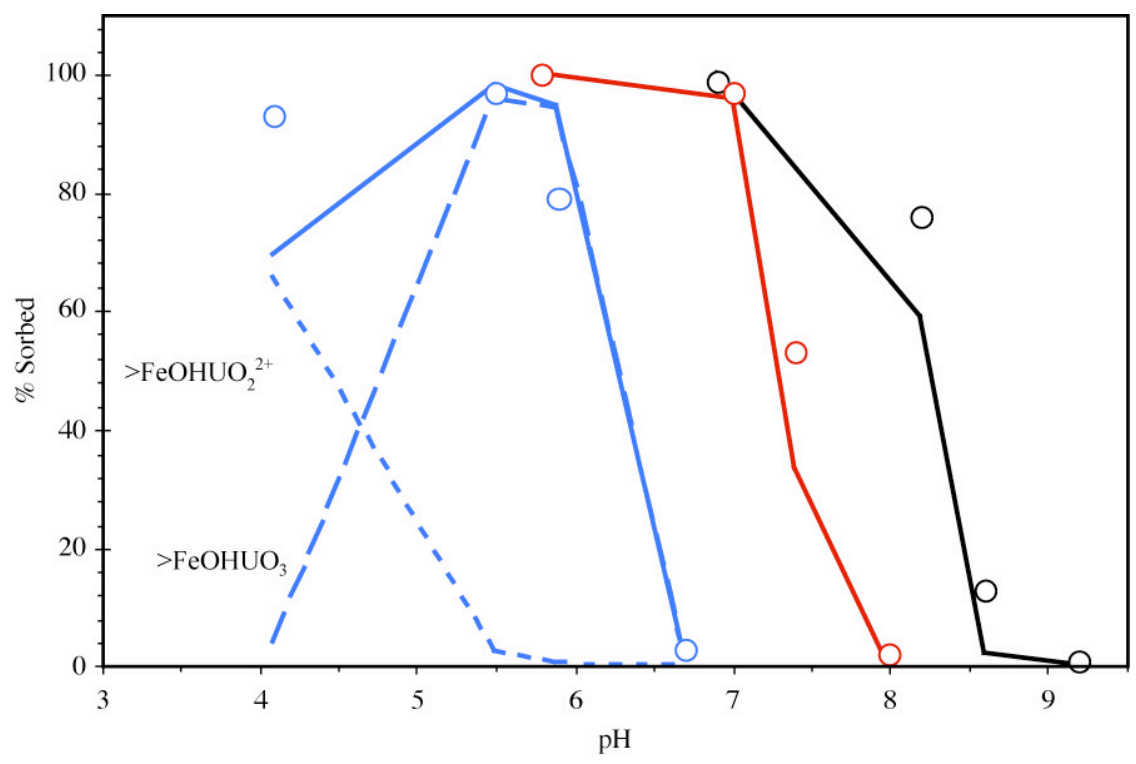

Figure 32. Sorption of U(VI) on FeOOH at $0.2 \%$ (black), $5 \%$ (red), and $90 \%$ (blue) $\mathrm{CO}_{2}$ (g) partial pressure (1 atm). Solid lines represent model prediction using NEM constants from Table 2. Dashed lines represent individual contributions of two surface species for samples at $90 \% \mathrm{CO}_{2}(\mathrm{~g})$. $\mathrm{I}=0.1$, total U(VI) $=8.4 \times 10^{-6} \mathrm{~mol} / \mathrm{L}, 8 \mathrm{~g} / \mathrm{L} \mathrm{FeOOH}$, and $60 \mathrm{~m}^{2} / \mathrm{g} \mathrm{FeOOH}$. Data from Duff and Amrhein (1996).

\subsection{U(VI) on Calcite}

The U(VI) NEM constant listed in Table 1 and Table 3 was determined by Carroll and Bruno (1991). Re-fitting the data was not necessary because they used a NEM approach equivalent to the one used here. Carroll and Bruno (1991) suggested that U(VI) sorption to calcite is very weak. Simple 1D reactive transport simulations, discussed in Section 5, show that iron oxide minerals control the migration of $\mathrm{U}(\mathrm{VI})$ in alluvial sediments containing carbonate and iron oxides minerals. Carbonate minerals, in effect, contribute very little to $\mathrm{U}(\mathrm{VI})$ retardation. 


\section{SUMMARY OF NON-ELECTROSTATIC MODEL DATABASE}

\subsection{Radionuclide Sorption to Iron Oxide Minerals}

Table 2 contains iron oxide NEM constants determined from fits to published sorption data. A short summary of the NEM fits and the resulting NEM database follows.

Table 2. Average non-electrostatic surface complexation constants for radionuclide interaction with iron oxides.

\begin{tabular}{|c|c|c|c|}
\hline Reaction & $\begin{array}{c}\text { \# of Curves } \\
\text { Evaluated }\end{array}$ & $\log K$ & Ref. \\
\hline $\begin{array}{c}>\mathrm{FeOH} \Leftrightarrow \mathrm{FeO}^{-}+\mathrm{H}^{+} \\
>\mathrm{FeOH}+\mathrm{H}^{+} \Leftrightarrow \mathrm{FeOH}_{2}^{+}\end{array}$ & & $\begin{array}{l}-8.93 \\
7.29\end{array}$ & 1 \\
\hline $\begin{aligned}>\mathrm{FeOH}+\mathrm{Am}^{3+} \Leftrightarrow & >\mathrm{FeOAm}{ }^{2+}+\mathrm{H}^{+} \\
>\mathrm{FeOH}+\mathrm{Am}^{3+} \Leftrightarrow & >\mathrm{FeOAm}(\mathrm{OH})_{2}+\mathrm{H}^{+}\end{aligned}$ & 11 & $\begin{array}{c}1.24 \pm 0.43 \\
-15.29 \pm 0.37\end{array}$ & 14 \\
\hline$>\mathrm{FeOH}+\mathrm{Eu}^{3+} \Leftrightarrow>\mathrm{FeOEu}^{2+}+\mathrm{H}^{+}$ & 11 & $1.86 \pm 0.67$ & $2-4$ \\
\hline $\begin{aligned}>\mathrm{FeOH}+\mathrm{NpO}_{2}^{+} & \Leftrightarrow>\mathrm{FeOHNpO}_{2}^{+} \\
>\mathrm{FeOH}+\mathrm{NpO}_{2}^{+}+\mathrm{H}_{2} \mathrm{O} & \Leftrightarrow>\mathrm{FeOHNpO}_{3}^{-}+2 \mathrm{H}^{+}\end{aligned}$ & 10 & $\begin{array}{l}4.32 \pm 0.11 \\
\quad-11.26\end{array}$ & 5,6 \\
\hline $\begin{array}{l}>\mathrm{FeOH}+\mathrm{Pu}^{4+}+\mathrm{H}_{2} \mathrm{O} \Leftrightarrow>\mathrm{FeOHPuO}^{2+}+2 \mathrm{H}^{+} \\
>\mathrm{FeOH}+\mathrm{Pu}^{4+}+2 \mathrm{H}_{2} \mathrm{O} \Leftrightarrow>\mathrm{FeOHPuO}_{2}+4 \mathrm{H}^{+}\end{array}$ & 2 & $\begin{array}{r}6.93 \\
-1.29\end{array}$ & 7 \\
\hline $\begin{aligned}>\mathrm{FeOH}+\mathrm{PuO}_{2}^{+} & \Leftrightarrow>\mathrm{FeOHPuO}_{2}^{+} \\
>\mathrm{FeOH}+\mathrm{PuO}_{2}^{+}+\mathrm{H}_{2} \mathrm{O} & \Leftrightarrow>\mathrm{FeOHPuO}_{3}^{-}+2 \mathrm{H}^{+}\end{aligned}$ & 2 & $\begin{array}{l}4.79 \\
-10.66\end{array}$ & 7 \\
\hline $\begin{aligned} &>\mathrm{FeOH}+\mathrm{Sr}^{2+} \Leftrightarrow>\mathrm{FeOHSr}^{2+} \\
&>\mathrm{FeOH}+\mathrm{Sr}^{2+} \Leftrightarrow>\mathrm{FeOSr}^{+}+\mathrm{H}^{+} \\
&>\mathrm{FeOH}+\mathrm{Sr}^{2+}+\mathrm{H}_{2} \mathrm{O} \Leftrightarrow>\mathrm{FeOSrOH}+2 \mathrm{H}^{+}\end{aligned}$ & 12 & $\begin{array}{c}2.22 \pm 0.13 \\
-5.30 \pm 0.31 \\
-14.14 \pm 0.40\end{array}$ & 8,9 \\
\hline $\begin{array}{c}>\mathrm{FeOH}+\mathrm{UO}_{2}{ }^{2+}+\mathrm{H}_{2} \mathrm{O} \Leftrightarrow>\mathrm{FeOHUO}_{3}+2 \mathrm{H}^{+} \\
>\mathrm{FeOH}+\mathrm{UO}_{2}{ }^{2+} \Leftrightarrow>\mathrm{FeOHUO}_{2}{ }^{2+}\end{array}$ & 17 & $\begin{array}{c}-3.05 \pm 0.43 \\
6.63 \pm 0.54\end{array}$ & $10-13$ \\
\hline
\end{tabular}

REFERENCES: 1. (Turner, 1995); 2. (Fujita and Tsukamoto, 1997) 3. (Ledin et al., 1994); 4. (Rabung et al., 1998); 5. (Girvin et al., 1991); 6. (Nakayama and Sakamoto, 1991); 7. (Sanchez et al., 1985);

8. (Kinniburgh et al., 1975); 9. (Kolarik, 1961); 10. (Duff and Amrhein, 1996); 11. (Hsi and Langmuir, 1985); 12. (Viani and Torretto,1998); 13. (Waite et al., 1994). 14. (Cromieres, 1996) 
In general, simple binary NEM reactions adequately fit the available published data; there was no need to add more complex bidentate or ternary surface complexes. ${ }^{7}$ One NEM reaction was necessary to fit the available data for $\mathrm{Eu}(\mathrm{III})$, two NEM reactions were necessary for $\mathrm{Am}(\mathrm{III}), \mathrm{Np}(\mathrm{V}), \mathrm{Pu}(\mathrm{IV}), \mathrm{Pu}(\mathrm{V})$, and $\mathrm{U}(\mathrm{VI})$, while $\mathrm{Sr}(\mathrm{II})$ required three separate reactions. ${ }^{8}$ For $\operatorname{Sr}(\mathrm{II})$, data was initially fit with a single reaction. Since the resulting model was not able to adequately describe the data, additional NEM reactions were added. Thus, $\mathrm{Sr}$ (II) sorption data was adequately fit only when $>\mathrm{FeOHSr}^{2+}$, $>\mathrm{FeOSr}^{+}$, and $>\mathrm{FeOSrOH}$ surface species were included. For all radionuclides, the minimum number of NEM reactions was used to adequately fit all data.

The $\mathrm{Np}(\mathrm{V})$ and $\mathrm{Pu}(\mathrm{V}) \mathrm{NEM}$ constants are similar (varying by $0.6 \log$ units or less) which is expected given their similar electronic configuration and aqueous complexation behavior. The same can be said of $\mathrm{Eu}(\mathrm{III})$ and $\mathrm{Am}(\mathrm{III}) ;>\mathrm{FeOAm}^{2+}$ and $>\mathrm{FeOEu}^{2+} \mathrm{NEM}$ constants vary by $0.62 \mathrm{log}$ units. Evidence for a $\mathrm{Eu}(\mathrm{III})$ surface species equivalent to $>\mathrm{FeOAm}(\mathrm{OH})_{2}$ exists but evidence was too scarce to justify inclusion in the NEM database (Table 2).

A one-site model could not always fit sorption at both high and low surface loads. The change in sorption affinity at high $\mathrm{Sr}$ (II) and Eu(III) surface loads (see data of Kolarik (1961) and Rabung et al. (1998), respectively) is indicative of sorption to multiple sites and possible electrostatic effects (e.g. Dzombak and Morel (1990)). A change in sorption affinity with increasing surface load was not detected in U(VI) sorption data; U(VI) sorption data from trace up to near saturation loads were fit adequately using the one-site NEM. The failure of the one-site NEM at high Sr(II) and Eu(III) surface loads illustrates an important limitation to our approach. However, this limitation of the one-site NEM should not be observed in cases where the radionuclide concentrations are relatively low. This is believed to be the case at NTS.

All $\mathrm{Am}(\mathrm{III}), \mathrm{Np}(\mathrm{V}), \mathrm{Pu}(\mathrm{IV})$, and $\mathrm{Pu}(\mathrm{V})$ sorption data examined in this report were collected at relatively low surface loads $(<10 \%)$ and fits to all the data could be accomplished using the one-site NEM. Data were not available to evaluate whether multiple sites would be necessary to fit sorption data at high surface loads.

No attempt was made to directly account for competition between groundwater ions and radionuclides for surface sites. Some surface sites are likely to be occupied by $\mathrm{CO}_{3}^{2-}$, $\mathrm{Ca}^{2+}, \mathrm{Mg}^{2+}, \mathrm{SO}_{4}{ }^{2-}$ or $\mathrm{PO}_{4}{ }^{3-}$ groundwater ions. However, as described by Tompson et al. (1999), REACT (Bethke, 1998) calculations indicate that the majority of iron oxide surface sites will not be occupied by groundwater ions. Thus, competition for surface

\footnotetext{
${ }^{7}$ Although SC reactions imply specific surface structures, these were not compared to spectroscopic surface structural information. Direct spectroscopic evidence of this nature is limited. The intention of our approach was to develop the simplest NEM that can adequately predict all available sorption data.

${ }^{8}$ Some data fits for Eu were improved when a second surface species was used, similar to the second surface species of Am. However, sufficient data was not available to develop a reaction constant for this second surface species with reasonable certainty. See Table 7 for detailed information of Eu sorption data fits.
} 
sites by major groundwater ions is not likely to occur. In our sorption data fitting, the effect of $\mathrm{pCO}_{2}(\mathrm{~g})$ on $\mathrm{U}(\mathrm{VI})$ sorption to iron oxides was entirely accounted for by radionuclide-carbonate aqueous complexation and not by competition for surface sites; $\mathrm{U}(\mathrm{VI})$ sorption as a function of carbonate alkalinity did not require $\mathrm{CO}_{3}{ }^{2-}$ or ternary $\mathrm{SC}$ reactions. For example, Figure 32 is a plot of $\mathrm{U}(\mathrm{VI})$ sorption as a function of $\mathrm{pH}$ at 3 different $\mathrm{CO}_{2}$ partial pressures (from Duff and Amrhein (1996)). The two surface complexes listed in Table 2 were able to predict U(VI) sorption as a function of $\mathrm{CO}_{2}$ partial pressure. The only significant difference between the data and prediction of Figure 32 occurs at low pH. However, it should be noted that the predicted sorption was based on average NEM contants determined from multiple sorption data sets (i.e. Table 2). A better match could be achieved if NEM constants were optimized specifically for this data set.

Reaction constant standard deviations in Table 2 are listed for those average log $K$ s that are based on three or more data sets. The reported standard deviations relate to the differences in fitted $\log K$ constants from the various batch sorption data sets. Standard deviations could not be calculated when less than three data sets were used to calculate the average $\log K$ or when the most conservative constant was chosen for the database. In general, $\log K$ standard deviations are $\leq 0.5$. This large uncertainty should not be surprising given the many simplifications used to fit a wide range of mineralogies and solution compositions. While many other mechanistic model parameter uncertainties exist but are not identified in this report, the scale of $\log K$ uncertainty may be used as a measure of how the mechanistic model uncertainty is expressed in reactive transport model results (Section 5). In general, uncertainty in the sorptive behavior of natural minerals is likely to be large. For example, Davis et al. (1998) noted that the surface charging behavior of non-ideal natural mineral phases is not well known. This difference may significantly affect the sorptive properties of natural iron oxide minerals. If the reactive surface area of natural iron oxide minerals is not well known, sorption may be underestimated or overestimated as well. Surface protonation/deprotonation log Ks have been shown to vary significantly due to ion substitution in iron oxide minerals (Sun et al., 1998). This may also affect the sorptive potential of natural iron oxide minerals. By generalizing the NEM to all iron oxide minerals and ignoring electrostatic effects, the constants listed in Table 2 are less specific to the behavior of a particular iron oxide mineral phase but result in larger $\log K$ standard deviations than might otherwise be expected.

Due to the complexity of Pu redox chemistry at the iron oxide surface, some additional discussion of Pu surface complexation is warranted. Sanchez et al. (1985) examined the sorptive properties of goethite for $\mathrm{Pu}$ at two oxidation states. They observed that during the course of $\mathrm{Pu}(\mathrm{V})$ sorption experiments (hours to days), significant reduction to $\mathrm{Pu}(\mathrm{IV})$ occurred. They hypothesized that the iron oxide surface promoted $\mathrm{Pu}(\mathrm{V})$ reduction either by catalyzing sorbed $\mathrm{Pu}(\mathrm{V})$ reduction or by increasing aqueous $\mathrm{Pu}(\mathrm{V})$ reduction due to strong $\mathrm{Pu}(\mathrm{IV})$ sorption. Keeney-Kennicutt and Morse (1985) made similar observations for iron oxide though the same observation was not made for other minerals (e.g. $\mathrm{MnO}_{2}$, calcite, and aragonite). Regardless of the mechanism, the results indicated that $\mathrm{Pu}(\mathrm{IV})$ sorption at atmospheric conditions may be important in Pu transport. Figure 
33 is a plot of sorbed and aqueous Pu concentration as a function of $\mathrm{pH}$. These REACT calculations were made by assuming a solution composition similar to that of Sanchez et al. (1985). At an $\mathrm{O}_{2}(\mathrm{~g})$ fugacity of 0.2 bars (equilibrium with the atmosphere), $\mathrm{Pu}(\mathrm{VI})$ is the dominant aqueous oxidation state while $\mathrm{Pu}(\mathrm{V})$ dominates the sorbed fraction. Sorbed $\mathrm{Pu}(\mathrm{IV})$ is one to two orders of magnitude lower in concentration than $\mathrm{Pu}(\mathrm{V})$. Although these results do not match the observations of Sanchez et al. (1985) or Keeney-Kennicutt and Morse (1985), the results do indicate that the iron oxide surface is able to sequester $\mathrm{Pu}$ at oxidation states significantly different from the dominant aqueous species. Figure 34 is an equilibrium sorption plot at an $\mathrm{O}_{2}(\mathrm{~g})$ fugacity of $10^{-10}$ bars. In this case, $\mathrm{Pu}(\mathrm{V})$ dominates as the aqueous oxidation state and $\mathrm{Pu}(\mathrm{IV})$ the sorbed oxidation state (for the majority of the $\mathrm{pH}$ range). Thus, model results for a solution somewhat under-saturated with respect to atmospheric oxygen are in good agreement with the data of Sanchez et al. (1985). These simulation results indicate that equilibrium thermodynamic and SC reactions can qualitatively predict the observed oxidation state variation between aqueous and sorbed $\mathrm{Pu}$.

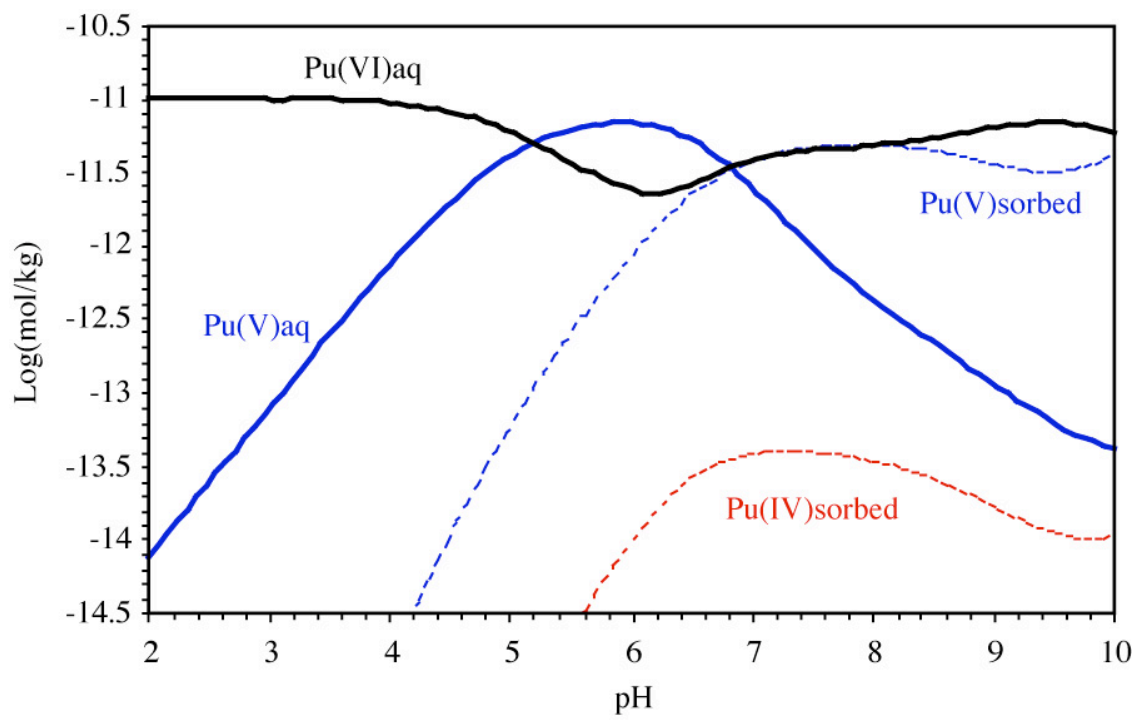

Figure 33. Oxidation states of dominant sorbed (dashed lines) and aqueous (solid lines) Pu species at $177 \mathrm{mg} / \mathrm{L}$ carbonate alkalinity and 0.2 bar $\mathrm{O}_{2}(\mathrm{~g})$ fugacity. Solution conditions similar to those of Sanchez et al. (1985) with $10^{-11} \mathrm{~mol} / \mathrm{L} \mathrm{Pu}$. 


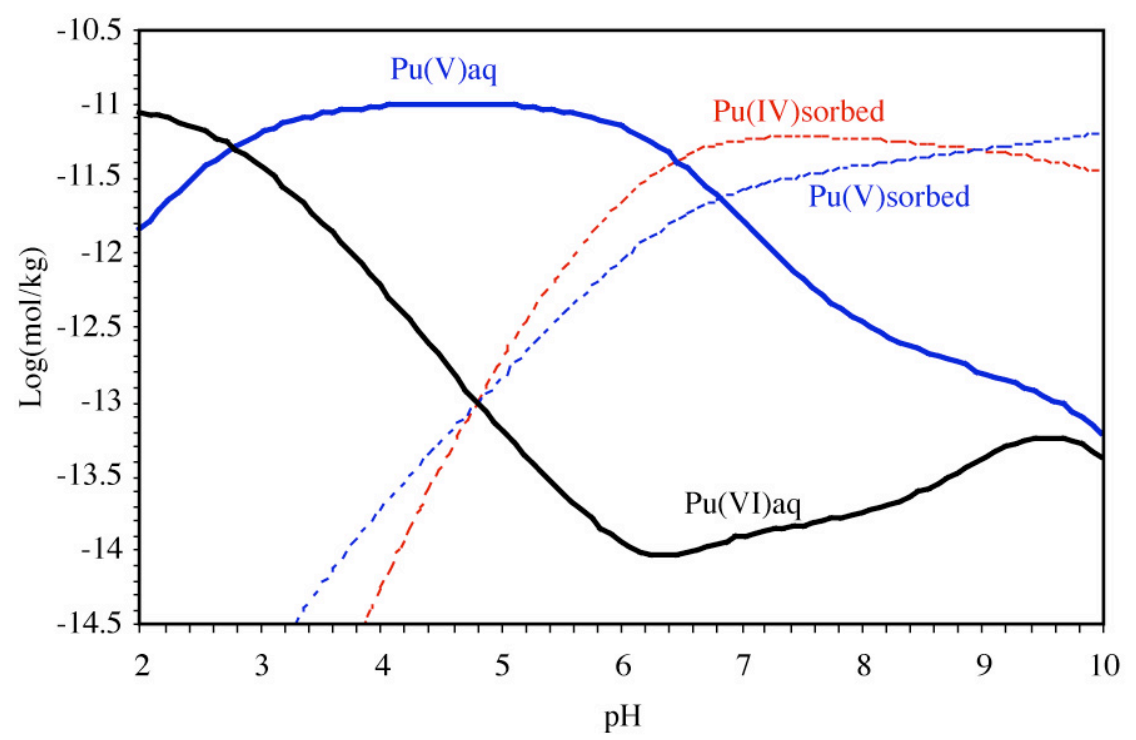

Figure 34. Oxidation states of dominant sorbed (dashed lines) and aqueous (solid lines) Pu species at $177 \mathrm{mg} / \mathrm{L}$ carbonate alkalinity and $\mathrm{O}_{2}(\mathrm{~g})$ fugacity $010^{-10}$ bars. Solution conditions similar to those of Sanchez et al. (1985) with $10^{-11} \mathrm{~mol} / \mathrm{L} \mathrm{Pu}$.

For 1D reactive transport simulations (Section 5), the oxygen fugacity in simulated groundwater was set at either 0.2 (equilibrium with the atmosphere) or $10^{-7}$ bars. Since the $\mathrm{O}_{2}(\mathrm{~g})$ fugacity of groundwater in the cavities of underground nuclear tests is not known, conservative Pu transport can be estimated by forcing simulated groundwater to an equilibrium state with atmospheric $\mathrm{O}_{2}(\mathrm{~g})$. For example, Figure 35 is a plot of aqueous $\mathrm{Pu}$ concentrations as a function of $\mathrm{pH}$ for four sorption envelopes in which the $\mathrm{O}_{2}(\mathrm{~g})$ fugacity was varied from atmospheric equilibrium to $10^{-30}$ bars (sorption solution condition based on Sanchez et al. (1985)). As the $\mathrm{O}_{2}$ (g) fugacity is lowered, the aqueous $\mathrm{Pu}$ concentration decreases (except at the lowest $\mathrm{pH}$ ). A decrease in aqueous $\mathrm{Pu}$ indicates greater Pu sorption. Figure 34 indicates that Pu sorption increases under reducing conditions. It also indicates that the most conservative estimate of Pu migration will occur when oxic solution conditions are assumed. 


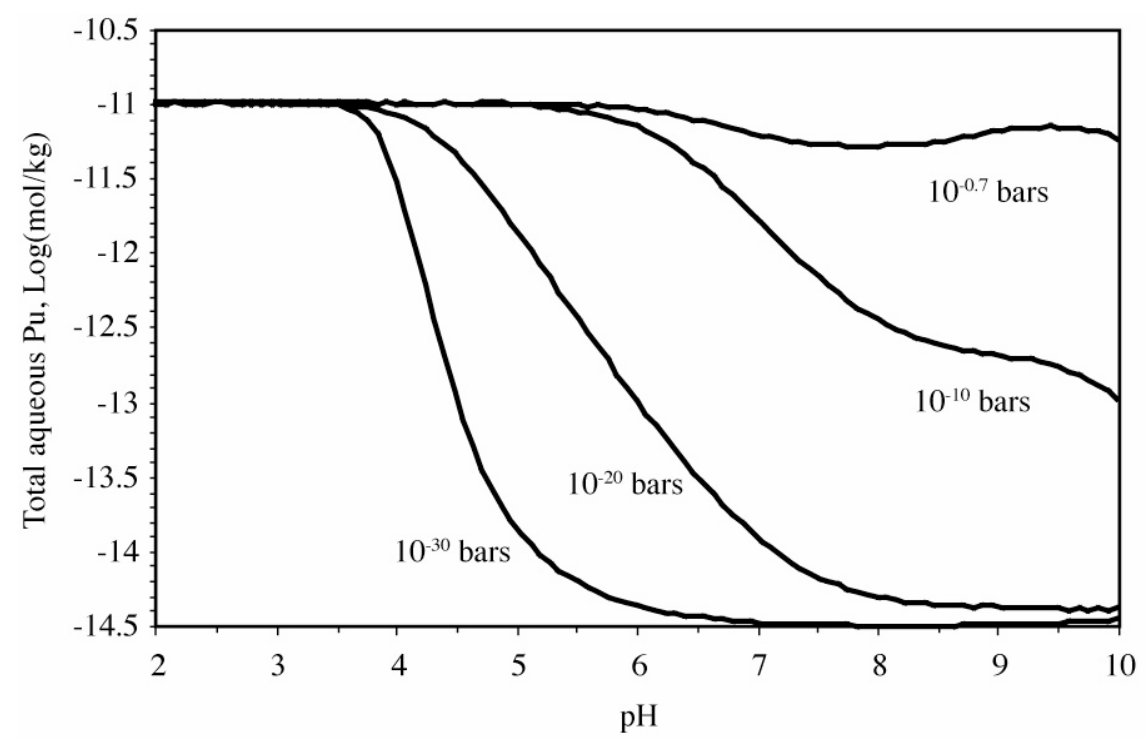

Figure 35. Aqueous concentration of Pu in Four REACT model runs using solution conditions of Sanchez et al. (1985). For each model run, all solution conditions were identical except for the change in $\mathrm{O}_{2}(\mathrm{~g})$ fugacity (as listed in figure).

Data for some radionuclide-iron oxide sorption pairs of interest could not be found in the literature but can be predicted based on analog radionuclide behavior. For example, published data regarding Sm(III) sorption to iron oxide minerals was not found. However, one can predict that the behavior of $\mathrm{Sm}(\mathrm{III})$ will be analogous to $\mathrm{Eu}(\mathrm{III})$; rare earth elements are often assumed to behave similarly, with $K_{d}$ s decreasing slightly with increased rare earth element atomic number (Koeppenkastrop and Decarlo, 1992; Zhong and Mucci, 1995). This extrapolation was used in 1D reactive transport simulations (Section 5) to evaluate Sm(III) migration. Extrapolation of NEM constants listed in Table 2 to other radionuclides is possible (e.g. extrapolation of Eu(III) reactions to other rare earth elements) but the limitations to these extrapolations must always be acknowledged.

\subsection{Radionuclide Sorption to Carbonate Minerals}

Calcite average NEM constants are listed in Table 3. The NEM constants for calcite were determined from a limited set of published radionuclide sorption data and recent sorption data collected for the UGTA program (Appendices A and B). Although there are some data available regarding the sorptive properties of calcite for divalent cations (Doner and Zavarin, 1997; Zachara et al., 1991), the sorption of actinides and lanthanides to calcite is less well known. Nevertheless, the information available indicates that, for certain elements, calcite can be an important sorbent. For example, Keeney-Kennicutt and Morse (1984) found that, on a mineral surface area basis, the importance of particular minerals with respect to $\mathrm{Np}(\mathrm{V})$ sorption follows the order: aragonite $\geq$ calcite $>$ goethite $>\mathrm{MnO}_{2} \approx$ clays. Keeney-Kennicutt and Morse (1985) also found that, on a mineral 
surface area basis, calcite sorbs $\mathrm{Pu}(\mathrm{V})$ only slightly less that goethite. Given that calcite is relatively abundant at Frenchman Flat and other NTS sites, it is likely to play an important role in radionuclide migration.

Table 3. Average non-electrostatic surface exchange constants for radionuclide interaction with calcite.

\begin{tabular}{|c|c|c|c|}
\hline Reaction & \multirow{2}{*}{$\begin{array}{c}\text { \# of Curves } \\
\text { Evaluated } \\
10^{\mathrm{a}}\end{array}$} & \multirow{2}{*}{$\begin{array}{c}\log K \\
4.13 \pm 0.06\end{array}$} & \multirow{2}{*}{$\begin{array}{r}\text { Ref. } \\
1\end{array}$} \\
\hline$>\mathrm{Ca}^{2+}+\mathrm{AmCO}_{3}^{+} \Leftrightarrow>\mathrm{AmCO}_{3}^{+}+\mathrm{Ca}^{2+}$ & & & \\
\hline$>\mathrm{Ca}^{2+}+\mathrm{EuCO}_{3}^{+} \Leftrightarrow>\mathrm{EuCO}_{3}^{+}+\mathrm{Ca}^{2+}$ & $2^{\mathrm{a}}, 1$ & 4.14 & 2,7 \\
\hline$>\mathrm{Ca}^{2+}+\mathrm{LaCO}_{3}^{+} \Leftrightarrow>\mathrm{LaCO}_{3}^{+}+\mathrm{Ca}^{2+}$ & $2^{\mathrm{a}}$ & 3.24 & 2 \\
\hline$>\mathrm{Ca}^{2+}+\mathrm{NpO}_{2}^{+} \Leftrightarrow>\mathrm{NpO}_{2}^{+}+\mathrm{Ca}^{2+}$ & $8^{\mathrm{a}}, 1$ & 1.46 & 3,7 \\
\hline$>\mathrm{Ca}^{2+}+\mathrm{PuO}_{2}^{+} \Leftrightarrow>\mathrm{PuO}_{2}^{+}+\mathrm{Ca}^{2+}$ & $7^{\mathrm{a}}, 1$ & 1.74 & 4,8 \\
\hline$>\mathrm{Ca}^{2+}+\mathrm{Pu}(\mathrm{OH})_{3}^{+} \Leftrightarrow>\mathrm{Pu}(\mathrm{OH})_{3}^{+}+\mathrm{Ca}^{2+}$ & 1 & 7.23 & 8 \\
\hline$>\mathrm{Ca}^{2+}+\mathrm{SmCO}_{3}^{+} \Leftrightarrow>\mathrm{SmCO}_{3}^{+}+\mathrm{Ca}^{2+}$ & $2^{\mathrm{a}}, 1$ & 4.62 & 2,7 \\
\hline$>\mathrm{Ca}^{2+}+\mathrm{Sr}^{2+} \Leftrightarrow>\mathrm{Sr}^{2+}+\mathrm{Ca}^{2+}$ & 1 & -1.75 & 5 \\
\hline$>\mathrm{Ca}^{2+}+\mathrm{UO}_{2}^{2+} \Leftrightarrow>\mathrm{UO}_{2}^{2+}+\mathrm{Ca}^{2+}$ & $17^{\mathrm{a}}$ & 5.12 & 6 \\
\hline$>\mathrm{Ca}^{2+}+\mathrm{YbCO}_{3}^{+} \Leftrightarrow>\mathrm{YbCO}_{3}^{+}+\mathrm{Ca}^{2+}$ & $2^{\mathrm{a}}$ & 1.50 & 2 \\
\hline
\end{tabular}

a Single point data

REFERENCES: 1. (Shanbhag and Morse, 1982); 2. (Zhong and Mucci, 1995); 3. (KeeneyKennicutt and Morse, 1984); 4. (Keeney-Kennicutt and Morse, 1985); 5. (Zachara et al., 1991); 6. (Carroll and Bruno, 1991); 7. Appendix B; 8. Appendix C.

For Am(III), sorption data was available only at $\mathrm{pH} \sim 8$. The choice of sorbing species could not be constrained because information regarding sorption as a function of $\mathrm{pH}$ or alkalinity was not available. The mono-carbonate species was assigned by analogy to $\mathrm{Eu}(\mathrm{III})$. The behavior of $\mathrm{Am}(\mathrm{III})$ is expected to be similar to Eu(III) due to their similarity in aqueous speciation. This is reflected in the resulting NEM constants and provides additional confidence to the assigned reactivity of Am(III) (Table 3).

The NEM constants for all three trivalent cations (Am, Eu, and Sm) are similar. Differences in NEM constants can be related to changes in aqueous speciation, sorptive behavior, as well as the uncertainty in the fitted NEM constants. Furthermore, the accuracy of the NEM constants is strictly dependent on the quality of aqueous speciation data for these cations. In general, the aqueous complexation of these species is complex 
and the available data can be sparse. The NEM constants listed in Table 3 are, thus, valid strictly when used in conjunction with the aqueous species and thermodynamic constants used to derive these constants. Any changes to the aqueous speciation data will require NEM constants to be updated as well.

For $\mathrm{Sm}(\mathrm{III})$ and $\mathrm{Eu}(\mathrm{III})$, both sorption and coprecipitation data were available from Zhong and Mucci (1995). Trace element sorption data can be related to coprecipitation data through the Doerner-Hoskins rule (Stumm, 1992). The Doerner-Hoskins rule states that coprecipitation partitioning can be described as continuous surface monolayer equilibrium partitioning. The surface sorption reaction:

$\mathrm{Sr}^{2+}+>\mathrm{Ca}^{2+} \Leftrightarrow>\mathrm{Sr}^{2+}+\mathrm{Ca}^{2+}$

is, thus, equivalent to the coprecipitation reaction

$\mathrm{Sr}^{2+}+\mathrm{CaCO}_{3} \Leftrightarrow \mathrm{SrCO}_{3}+\mathrm{Ca}^{2+}$

where $>\mathrm{Ca}^{2+}$ and $>\mathrm{Sr}^{2+}$ are surface concentrations while $\mathrm{CaCO}_{3}$ and $\mathrm{SrCO}_{3}$ are nearsurface precipitate concentrations. For the sorption-coprecipitation relation to apply, equilibrium Log $K$ constants must be written with surface and precipitate concentrations as mol fractions. The sorption and coprecipitation fit results for $\mathrm{Sm}$ (III), Eu(III), and two other rare earth elements (La(III) and $\mathrm{Yb}(\mathrm{III})$ ) are listed in Table 4. ${ }^{9}$ Although the Log $K$ constants for sorption and coprecipitation fits are not identical, they are in approximate agreement. For example, $\mathrm{Yb}$ (III) sorption $\log K$ is 2.38 while the coprecipitation $\log K$ is 1.52; for $\mathrm{Sm}(\mathrm{III}), \mathrm{Eu}(\mathrm{III})$, and $\mathrm{La}(\mathrm{III})$, the differences are much smaller (log $K_{\text {coprecipitation }}$ $-\log K_{\text {sorption }}=0.35,-0.52$, and -0.25 , respectively). The difference in Log $K$ s may be due to non-equilibrium surface partitioning during precipitation or simply due to the rather limited number of partitioning data. For $\mathrm{La}(\mathrm{III})$ and $\mathrm{Yb}(\mathrm{III})$, the more conservative (as applies to radionuclide migration) Log $K$ was reported in Table 3.

\footnotetext{
${ }^{9} \mathrm{La}(\mathrm{III})$ and $\mathrm{Yb}$ (III) are not considered relevant to the UGTA project. The NEM constants for these two elements were evaluated simply for comparison with $\mathrm{Sm}(\mathrm{III})$ and $\mathrm{Eu}(\mathrm{III})$.
} 
Table 4. Comparison of non-electrostatic model fits to calcite sorption and coprecipitation data for selected radionuclides. ${ }^{a}$

\begin{tabular}{ccccc}
\hline Element & $\begin{array}{c}\text { Concentration } \\
\text { mol/L }\end{array}$ & Reaction & Species & $\mathrm{Log} K$ \\
\hline $\mathrm{La}$ & $7 \times 10^{-8}$ & $\begin{array}{c}\text { coprecipitation } \\
\text { sorption }\end{array}$ & $\mathrm{LaCO}_{3}$ & 3.49 \\
& $6.5 \times 10^{-7}$ & & & \\
& & & \\
& & & \\
$\mathrm{Sm}$ & $7 \times 10^{-8}$ & coprecipitation & $\mathrm{SmCO}_{3}$ & 2.24 \\
& $6.5 \times 10^{-7}$ & sorption & $>\mathrm{SmCO}_{3}^{+}$ & 3.03 \\
& & & & \\
$\mathrm{Eu}$ & $7 \times 10^{-8}$ & coprecipitation & $\mathrm{EuCO}_{3}$ & 2.57 \\
& $6.5 \times 10^{-7}$ & sorption & $>\mathrm{EuCO}_{3}^{+}$ & 3.09 \\
$\mathrm{Yb}$ & $7 \times 10^{-8}$ & coprecipitation & $\mathrm{YbCO}_{3}$ & 1.50 \\
& $6.5 \times 10^{-7}$ & sorption & $>\mathrm{YbCO}_{3}{ }^{+}$ & 2.38 \\
\hline
\end{tabular}

${ }^{a}$ Data from Zhong and Mucci (1995). All experiments were open to the atmosphere, in seawater solutions, at identical $\mathrm{Ca}^{2+}$ concentrations $(0.0177 \mathrm{~mol} / \mathrm{L})$, and a $\mathrm{pH}$ range of $8 \pm 0.5$.

For $\mathrm{Sm}(\mathrm{III})$ and $\mathrm{Eu}(\mathrm{III}), \mathrm{NEM}$ constants listed in Table 3 were based on recent fits to sorption data collected for the UGTA program. A summary report of these batch sorption experiments is included here as Appendix A. These batch sorption data were collected over a range of $\mathrm{pH}$ and were, therefore, considered more accurate than the single point data of Zhong and Mucci (1995). The Table 3 Sm(III) and Eu(III) NEM constants are higher than those based on the single point data (Table 4). The data of Zhong and Mucci (1995) was collected at very high rare earth element concentrations and all rare earth elements were sorbed to calcite in a single batch sorption experiment. This likely resulted in significant competition between sorbers for the calcite surface. Since this competition was not accounted for when fitting NEM constants, the resulting NEM constants are lower than would be expected at trace conditions.

For $\mathrm{Np}(\mathrm{V})$ and $\mathrm{Pu}(\mathrm{V})$, the positively charged aqueous species $\mathrm{NpO}_{2}{ }^{+}$and $\mathrm{PuO}_{2}{ }^{+}$were predicted to be the sorbing species. The $\log K$ constants for these two sorption reactions are similar, as expected. For $\mathrm{Np}(\mathrm{V})$, NEM constants listed in Table 3 can be compared with the sorption data of Triay et al. (1996). Their batch sorption studies were conducted in synthetic J-13 and UE-25p\#1 waters from Yucca Mountain. These waters are similar in composition to those typically found at NTS (discussed in following section). Singlepoint NEM constants were determined from raw data reported in Triay et al. (1996) and solution speciation calculations from REACT (Bethke, 1998). For reactions lasting 21 to 31 days, NEM constants for the $>\mathrm{NpO}_{2}{ }^{+}$species varied between 0.6 and 2.8 while the average and standard deviation of all measurements was 0.7 and 0.9 , respectively (the associated $K_{d} \mathrm{~s}$ varied from 800 to $1 \mathrm{~mL} / \mathrm{g}$ ). The high variability of fitted $\log K \mathrm{~s}$ illustrates the difficulty in determining calcite NEM constants. Calcite surfaces are unstable and can undergo dissolution, precipitation, recrystallization, and solid state 
diffusion reactions; this makes precise NEM constant quantification difficult. Nevertheless, the long-term reaction constants calculated from the data of Triay et al. (1996) are in agreement with results in Table 3.

The sorption of $\mathrm{Pu}(\mathrm{IV})$ on calcite was described in Davisson et al. (2002) as part of the UGTA project. We provide a detailed description of these data and the NEM fits in Appendix B. The resulting reaction constants are reported in Table 3. Under ambient NTS groundwater conditions, $\mathrm{Pu}(\mathrm{IV})$ will sorb much more strongly to calcite than $\mathrm{Pu}(\mathrm{V})$. As in the iron oxide case, the redox conditions of plutonium in the groundwater at NTS will dictate the predicted transport behavior of plutonium.

The U(VI) NEM constant was taken directly from the results of Carroll and Bruno (1991); their data were presented in the same surface exchange format used here. The Sr(II) NEM constant was fit to data of Zachara et al. (1991). U(VI) and Sr(II) sorption to calcite is weak and is not expected to significantly affect their migration in most cases. The affinity of these elements for the calcite surface compared to several other mineral surfaces is discussed in the following section. 


\section{1D REACTIVE TRANSPORT SIMULATIONS - THE ROLE OF CALCITE AND IRON OXIDE IN RADIONUCLIDE RETARDATION}

The influence of various NEM reactions and the role of calcite and iron oxide in radionuclide retardation is illustrated in the following $1 \mathrm{D}$ reactive transport simulation. In this simulation, 10 meters of contaminated alluvium is bounded by 10 meters of uncontaminated alluvium. The entire source term initially resides in the contaminated alluvium zone and is in the aqueous form. Transport is simulated assuming a simple linear groundwater flow of 1 meter/year Darcy flux. The initial concentration of the various radionuclides was arbitrarily set to $10^{-8} \mathrm{~mol} / \mathrm{L}$. While our reactive transport model could have accounted for competitive sorption between radionuclides, initial concentrations were set low enough that competitive sorption would not be observed. The radionuclide sorbing mineral abundances and groundwater composition in the simulated alluvium is listed in Table 5; the mineralogy and background groundwater composition is based on that described in Tompson et al. (1999) for alluvium near the Cambric site, Frenchman Flat. Aqueous speciation was based on the GEMBOCHS thermodynamic data base version data.com.V8.R6 (Johnson and Lundeen, 1997) with revisions as noted in Pawloski et al. (2001). A summary of aqueous speciation reactions is given in Appendix C. The GIMRT code (Steefel and Yabusaki, 1995) was used to simulate radionuclide transport over 500 years. Radioactive decay was not evaluated. 
Table 5. Composition of alluvium mineralogy and water chemistry used in a generic Frenchman Flat reactive transport simulation based on information in Tompson et al. (1999).

\begin{tabular}{|c|c|c|}
\hline Element & $\begin{array}{l}\text { Volume } \\
\text { Fraction }\end{array}$ & $\begin{array}{c}\text { Concentration } \\
\text { mol/L (except } \mathrm{pH})\end{array}$ \\
\hline $\mathrm{pH}$ & & 8 \\
\hline $\mathrm{SiO}_{2}(\mathrm{aq})$ & & $1.1 \times 10^{-3}$ \\
\hline $\mathrm{Na}^{+}$ & & $2.7 \times 10^{-3}$ \\
\hline $\mathrm{HCO}_{3}^{-}$ & & $2.8 \times 10^{-3}$ \\
\hline $\mathrm{Ca}^{2+}$ & & $4 \times 10^{-4}$ \\
\hline $\mathrm{K}^{+}$ & & $2 \times 10^{-4}$ \\
\hline $\mathrm{Mg}^{2+}$ & & $1.6 \times 10^{-4}$ \\
\hline $\mathrm{O}_{2}(\mathrm{aq})$ & & $2 \times 10^{-1}$ \\
\hline $\mathrm{SO}_{4}^{2-}$ & & $3.3 \times 10^{-4}$ \\
\hline $\mathrm{Am}^{3+}$ & & $10^{-8}+\dagger$ \\
\hline $\mathrm{Cs}^{+}$ & & $10^{-8}$ \\
\hline $\mathrm{Eu}^{3+}$ & & $10^{-8}$ \\
\hline $\mathrm{Np}^{4+}$ & & $10^{-8}$ \\
\hline $\mathrm{Pu}^{4+}$ & & $10^{-8}$ \\
\hline $\mathrm{Sm}^{3+}$ & & $10^{-8}$ \\
\hline $\mathrm{Sr}^{2+}$ & & $10^{-8}$ \\
\hline${ }^{3} \mathrm{H}$ & & $10^{-8}$ \\
\hline $\mathrm{UO}_{2}^{2+}$ & & $10^{-8}$ \\
\hline Porosity & $0.35 \dagger$ & \\
\hline Matrix & $0.52 \ddagger$ & \\
\hline Calcite $^{a}$ & 0.01 & \\
\hline Muscovite (mica) & 0.01 & \\
\hline Clinoptilolite & 0.05 & \\
\hline Beidellite§ & 0.05 & \\
\hline Goethite $^{\mathrm{b}}$ & 0.01 & \\
\hline
\end{tabular}

$\dagger$ Porosity of the alluvium zones was estimated at $35 \%$.

$\$ 52 \%$ of the alluvium was considered non-reactive and called "matrix".

$\S$ Beidellite was used to represent montmorillonite.

t† Alluvium zone and contaminated alluvium zone water composition was the same except that Am(III), $\mathrm{Cs}(\mathrm{I}), \mathrm{Eu}(\mathrm{III}), \mathrm{Np}(\mathrm{V}), \mathrm{Pu}(\mathrm{IV}), \mathrm{Sm}(\mathrm{III}), \mathrm{Sr}(\mathrm{II}),{ }^{3} \mathrm{H}$, and $\mathrm{U}(\mathrm{VI})$ concentrations in the alluvium zone were at background $\left(10^{-15} \mathrm{~mol} / \mathrm{L}\right)$ at $\mathrm{t}=0$.

${ }^{\text {a }}$ For surface complexation purposes, calcite surface area estimated to be $2.2 \mathrm{~m}^{2} / \mathrm{g}$. Reactive site density estimated to be 5.0 sites $/ \mathrm{nm}^{2}$.

${ }^{\mathrm{b}}$ For surface complexation purposes, goethite (an iron oxide) surface area estimated to be $50 \mathrm{~m}^{2} / \mathrm{g}$. Reactive site density estimated to be 2.31 sites $/ \mathrm{nm}^{2}$. 
Radionuclide retardation was based on the NEM constants developed in this report (Tables 2 and 3). Radionuclide precipitation and ion exchange could also influence radionuclide migration. Radionuclide precipitation was not included in this simulation. However, some ion exchange reactions were included. These reactions are expected to play an important role in $\mathrm{Cs}$ (I) and $\mathrm{Sr}$ (II) transport. The ion exchange reactions included in this 1D simulation are listed in Table 6. Additional information regarding ion exchange reactions can be found in Pawloski et al. (2001) and the companion report (Zavarin and Bruton, 2004).

Table 6. Ion exchange reactions used in GIMRT 1D simulations. Data taken from Viani and Bruton $(1992 ; 1996)$.

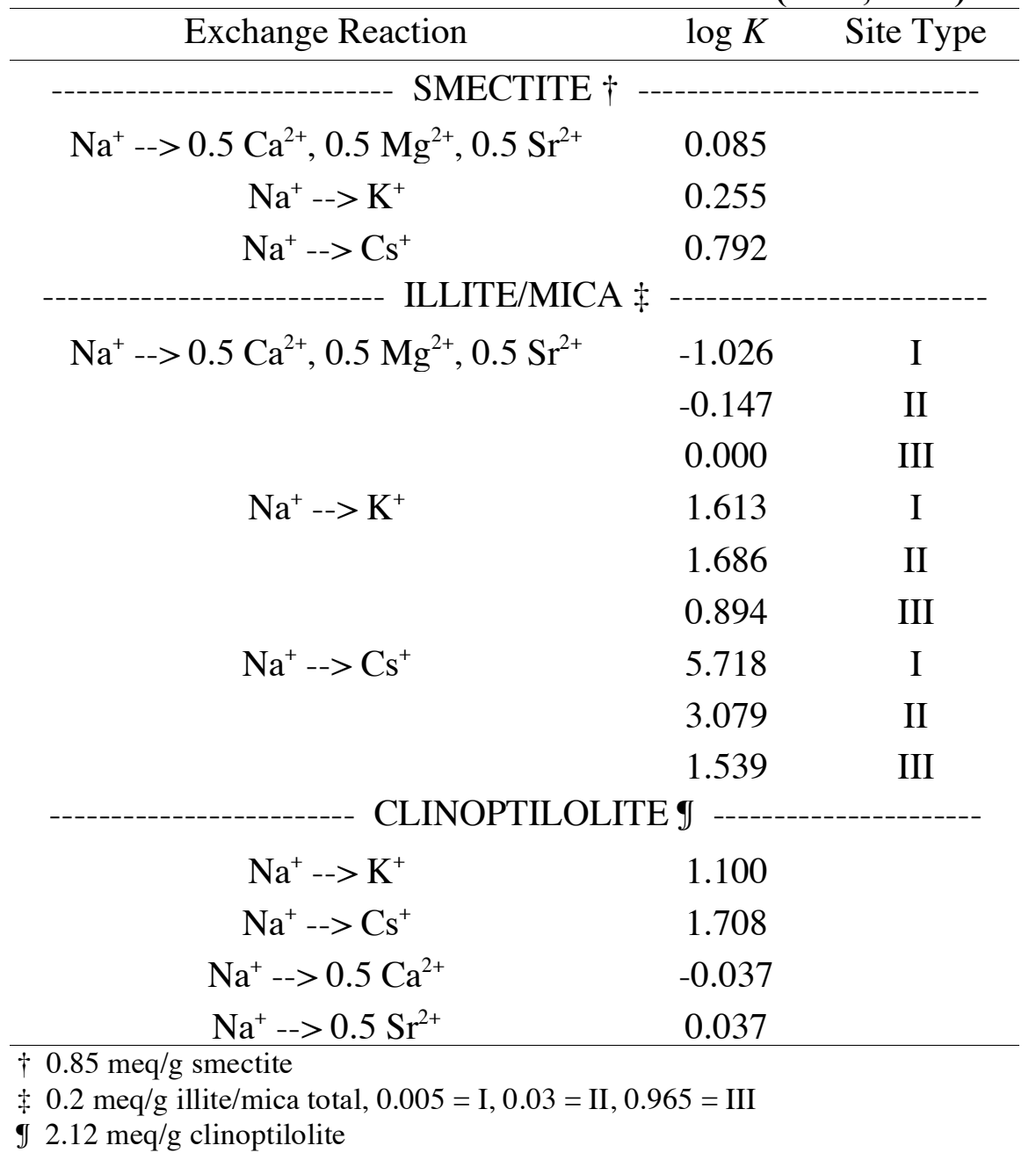

Am(III) migrated less than 5 meters outside the initially contaminated zone at 500 years (Figure 36). The aqueous Am(III) concentration remained essentially below background levels $\left(10^{-15} \mathrm{~mol} / \mathrm{L}\right)$ outside of the initial contaminated zone. The calcite sorbed Am(III) to a slightly greater extent than the iron oxide. However, either mineral was capable of 
removing $>99.99 \%$ of Am(III) from the groundwater under the simulated conditions. Nevertheless, these results suggest that calcite may be an important sorber at the NTS. Minimal Am(III) migration in calcareous environments has been observed in the Marshall islands where over $90 \%$ of all Am(III) has remained in the top 50 centimeters of calcareous soils (Robinson et al., 1998). The simulation results shown here are consistent with these observations.

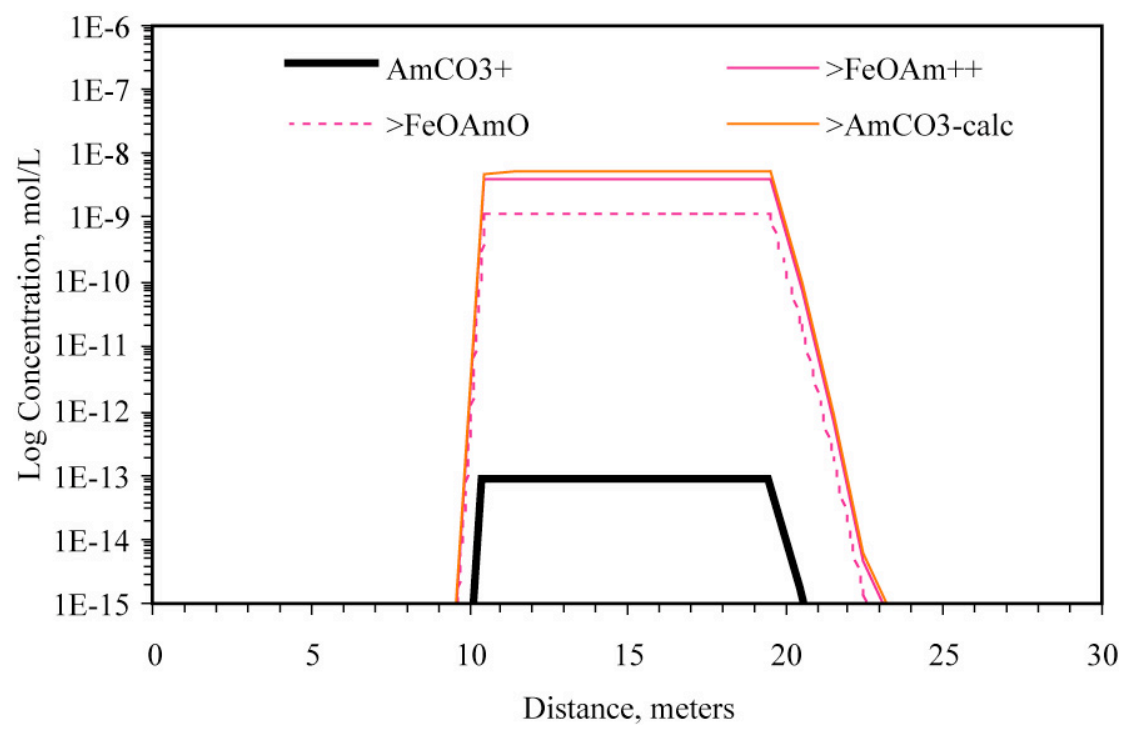

Figure 36. Distribution of dominant Am(III) aqueous species and surface complexes at 500 years.

Cs(I) migration was controlled by ion exchange processes (Figure 37). In this simulation, $\mathrm{Cs}(\mathrm{I})$ sorption to illite/mica dominated; primarily via the strong $\mathrm{Cs}(\mathrm{I})$ sorbing site (Site ill1, see Table 6). ${ }^{10}$ Sorption to clinoptilolite can have a significant effect on Cs(I) sorption as well. Within the initial contaminated zone, $80 \%$ of $\mathrm{Cs}(\mathrm{I})$ was associated with illite/mica while $20 \%$ was associated with clinoptilolite. Torstenfelt et al. (1982) examined $\mathrm{Cs}(\mathrm{I})$ sorption on a variety of minerals; the micas were found to sorb $\mathrm{Cs}(\mathrm{I})$ much more strongly than iron oxide or carbonate minerals (sorption to zeolites was not evaluated). The sorption of Cs(I) to iron oxide or carbonate minerals was, thus, not included in our simulations. Illite/mica is likely to be an effective Cs(I) sorber in these types of alluvial sediments and the dominant mechanism for $\mathrm{Cs}(\mathrm{I})$ retardation.

Clinoptilolite may also contribute to $\mathrm{Cs}(\mathrm{I})$ retardation when present in significant quantities.

${ }^{10}$ The sorptive behavior of illite and mica is assumed to be equivalent in our model. 


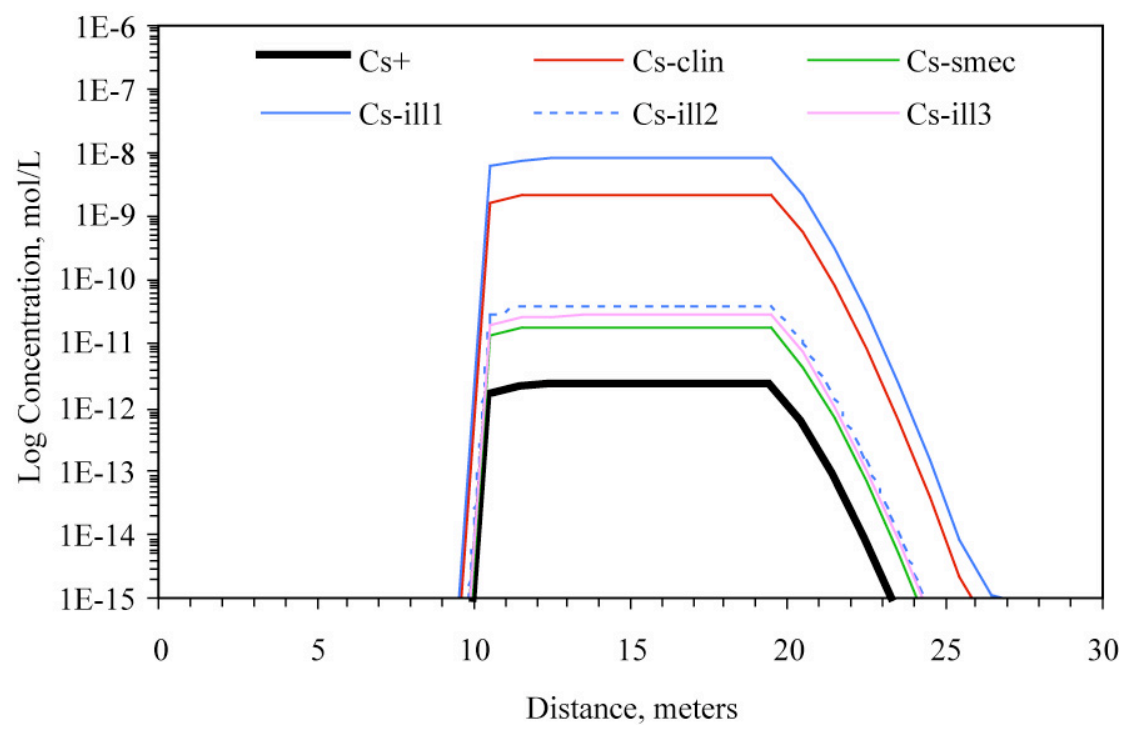

Figure 37. Distribution of $\mathrm{Cs}(\mathrm{I})$ aqueous and sorbed species at 500 years. Cs-ill\# = Cs bound to 3 sites of illite/mica; Cs-clin $=$ Cs on clinoptilolite; Cs-smec $=$ Cs on smectite

For $\mathrm{Eu}(\mathrm{III}), \mathrm{Np}(\mathrm{V})$, and $\mathrm{Pu}(\mathrm{IV}, \mathrm{V})$, both iron oxide and carbonate minerals contributed to radionuclide retardation (Figures 38-41). The combination of iron oxide and carbonate minerals in the alluvium reduced the $\mathrm{Eu}(\mathrm{III}), \mathrm{Np}(\mathrm{V})$, and total $\mathrm{Pu}$ aqueous concentrations by more than 2 orders of magnitude. The relative sorption strength of these radionuclides correlated with their relative migration distance. While Eu(III) migrated only $\sim 5$ meters outside the initial contaminated zone in 500 years (consistent with the behavior of Am), $\mathrm{Np}(\mathrm{V})$ migrated more than 10 meters. The migration distance of $\mathrm{Pu}$ was highly dependent on the redox state of $\mathrm{Pu}$ in the groundwater. When the dominant Pu oxidation state was +6 (Figure $9 ; \mathrm{O}_{2}(\mathrm{~g})$ fugacity of 0.2 bars), Pu migration was significantly greater than both $\mathrm{Eu}(\mathrm{III})$ and $\mathrm{Np}(\mathrm{V})$. When the dominant $\mathrm{Pu}$ oxidation state in groundwater was +5 (Figure 10; $\mathrm{O}_{2}(\mathrm{~g})$ fugacity of $10^{-7}$ bars), Pu migration decreased drastically. Under these more reducing conditions, the behavior of Pu mimicked that of $\mathrm{Np}(\mathrm{V})$. This should not be surprising since the speciation behavior of aqueous $\mathrm{NpO}_{2}{ }^{+}$and $\mathrm{PuO}_{2}{ }^{+}$is similar. 


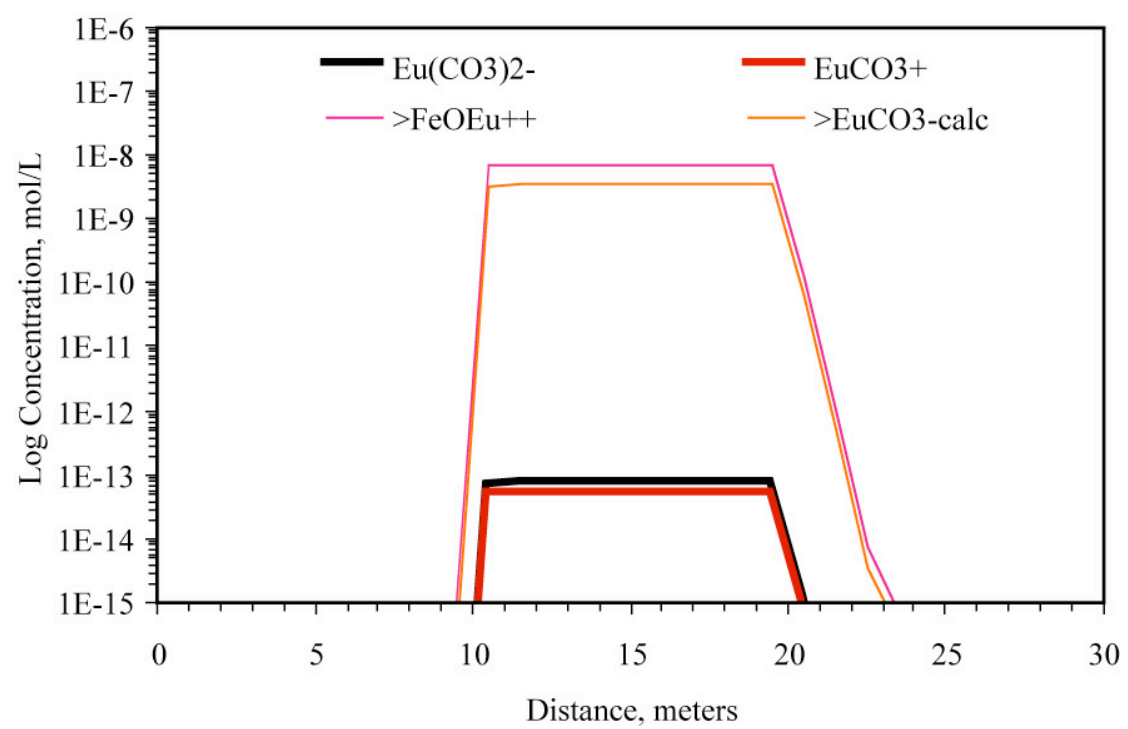

Figure 38. Distribution of dominant Eu(III) aqueous species and surface complexes at 500 years.

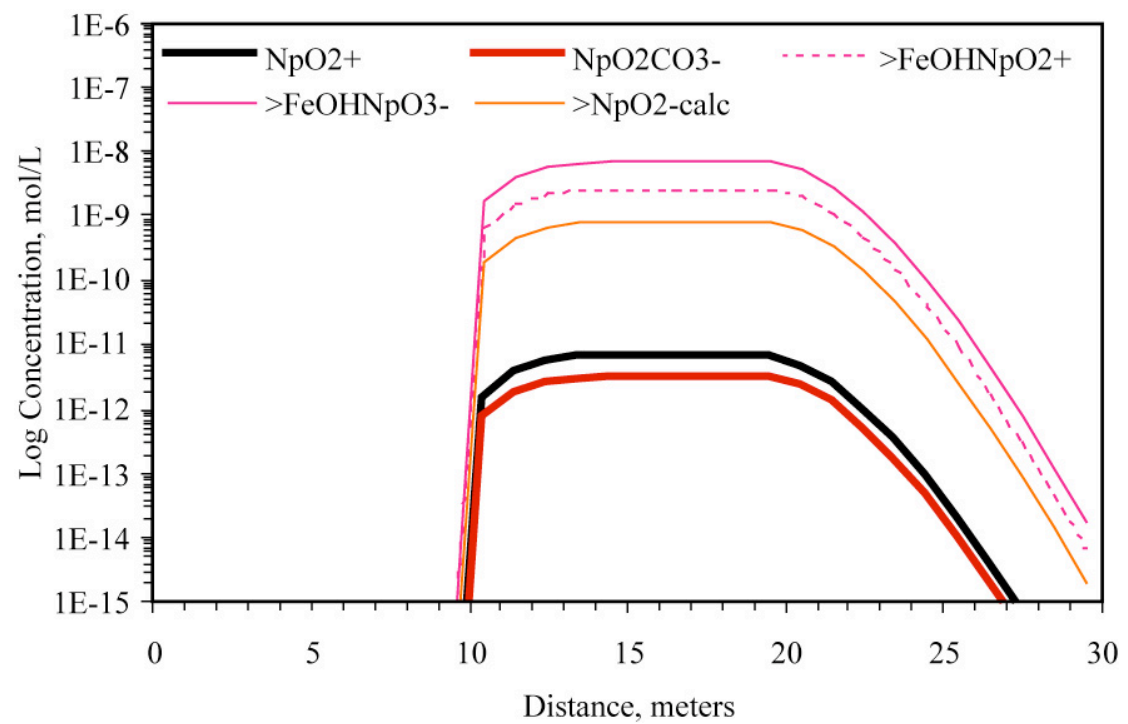

Figure 39. Distribution of dominant $N p(V)$ aqueous species and surface complexes at 500 years. 


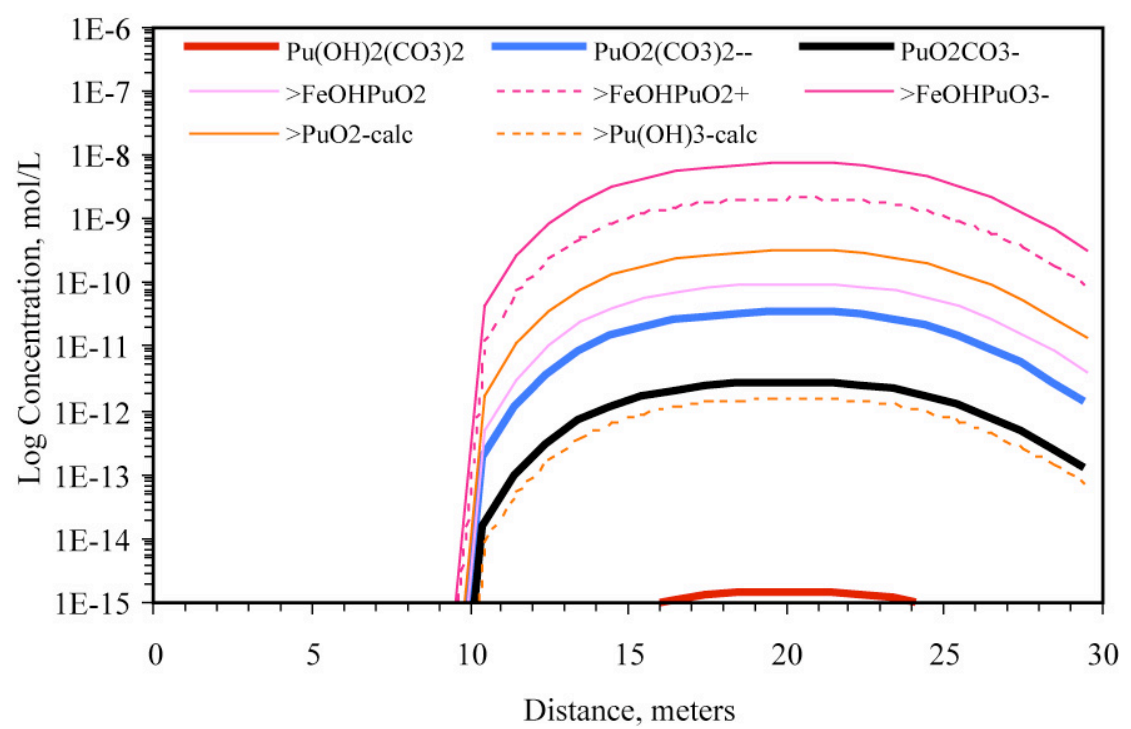

Figure 40. Distribution of dominant $P u$ aqueous species and surface complexes at 500 years $\left(\mathrm{O}_{2}(\mathrm{~g})\right.$ fugacity set to 0.2 bars). Dominant aqueous species for each oxidation state are shown.

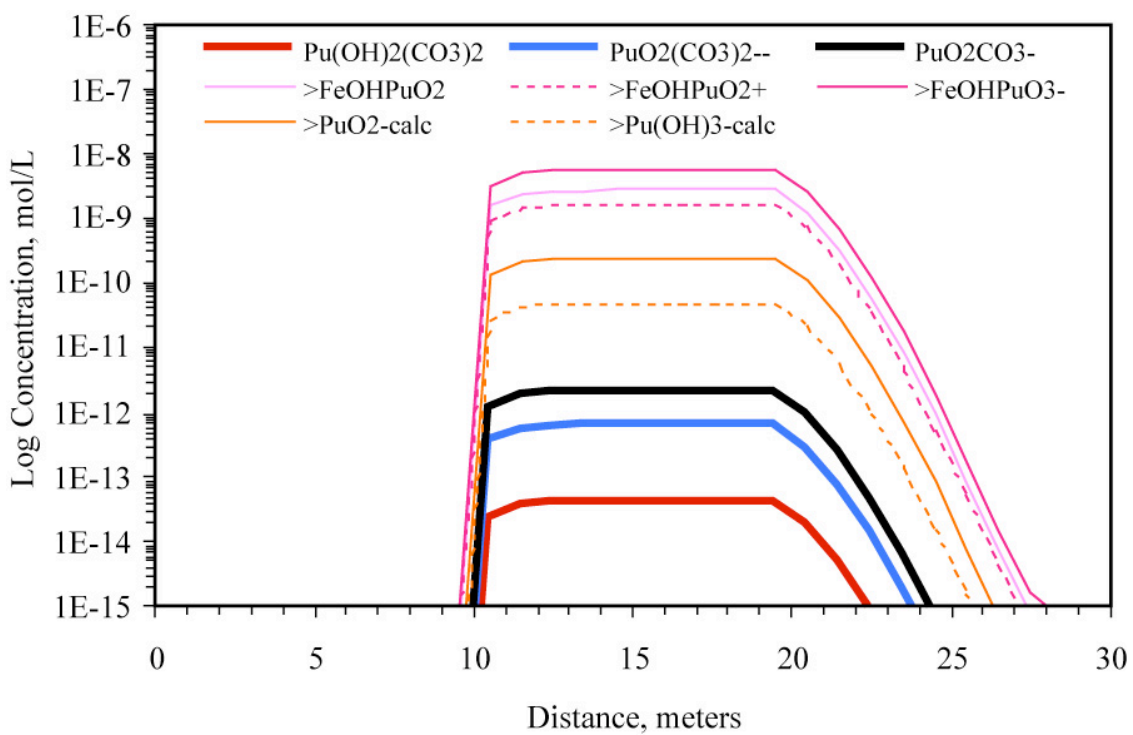

Figure 41. Distribution of dominant $P u$ aqueous species and surface complexes at 500 years $\left(\mathrm{O}_{2}(\mathrm{~g})\right.$ fugacity set to $10^{-7}$ bars). Dominant aqueous species for each oxidation state are shown.

The behavior of $\mathrm{Sm}(\mathrm{III})$ is quite similar to that of $\mathrm{Eu}(\mathrm{III})$ (compare Figures 38 and 42). $\mathrm{Sm}$ (III) sorption to iron oxides was based on the surface complexation constants calculated for $\mathrm{Eu}(\mathrm{III})$. This can be justified by comparing the sorption behavior of rare earth elements (i.e. Koeppenkastrop and Decarlo, 1992; Zhong and Mucci, 1995). However, it should be noted that the Sm(III) surface complexation to iron oxide is only an estimate. 
Simulation results suggest that the migration of $\mathrm{Sm}(\mathrm{III})$ and $\mathrm{Eu}(\mathrm{III})$ (as well as Am(III)) will be very slow under the simulated conditions. It should be noted, however, that the role of colloids and heterogeneous reactive mineral distribution was not examined in this 1D simulation. These factors may greatly affect the transport behavior of all radionuclides, but particularly those that would otherwise sorb strongly. See Tompson et al. (1999) and Pawloski et al. (2001) for details on the role of colloids and spatial heterogeneity.

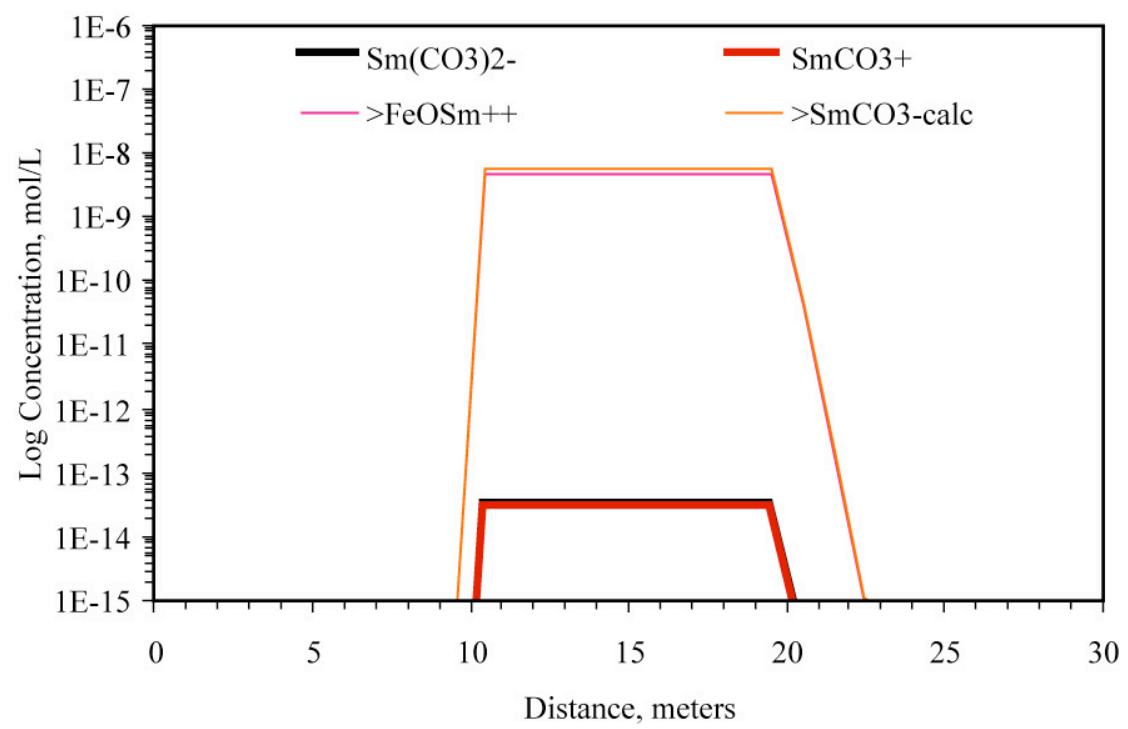

Figure 42. Distribution of dominant $\mathrm{Sm}$ (III) aqueous species and surface complexes at 500 years.

Sr(II) interaction with clinoptilolite, smectite, iron oxide, and carbonate minerals were all examined in the $1 \mathrm{D}$ simulation. Although calcite was not a significant $\mathrm{Sr}$ (II) sorber, all other minerals played a role in $\mathrm{Sr}$ (II) retardation (Figure 43). The combination of these surface reactions reduced the $\operatorname{Sr}(\mathrm{II})$ concentration in the rubble zone by 3 orders of magnitude. More than $90 \%$ of $\mathrm{Sr}$ (II) was associated with clinoptilolite. Thus zeolitized zones at the NTS will provide the strongest barrier to $\mathrm{Sr}(\mathrm{II})$ migration. 


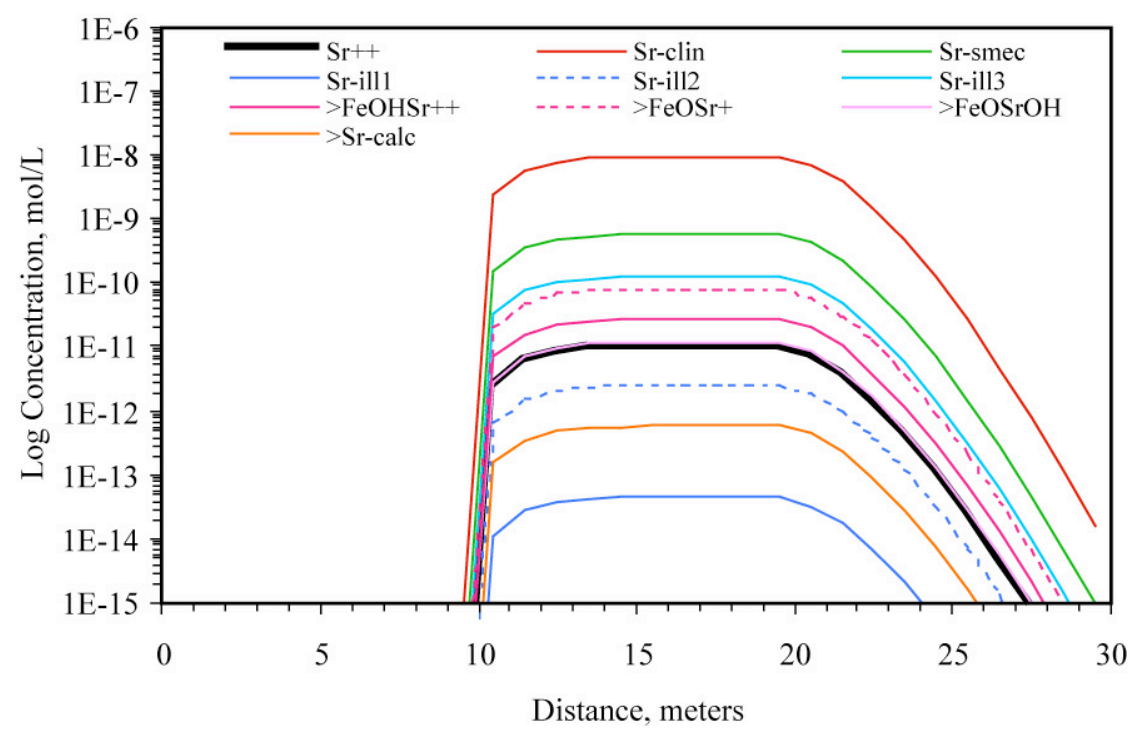

Figure 43. Distribution of $\operatorname{Sr}(\mathrm{II})$ aqueous species and surface complexes at 500 years.

U(VI) sorption to calcite did not contribute significantly to U(VI) retardation (Figure 44). Carroll and Bruno (1991) noted that U(VI) sorption to calcite is rather weak, consistent with our simulation results. Based on this 1D simulations, U(VI) sorption to iron oxide controlled migration.

In general, the surface complexation Log $K$ standard deviations (Tables 2 and 3 ) are relatively large $(\sim 0.5 \log K)$. Their effect on U(VI) transport can be examined by reducing the iron oxide surface complexation constants to two standard deviations below the mean $\left(\mathrm{Log} K\right.$ constants for $>\mathrm{FeOHUO}_{3}$ and $>\mathrm{FeOHUO}_{2}{ }^{2+}$ reduced to -3.91 and 5.55, respectively). Figure 45 is a plot of $\mathrm{U}(\mathrm{VI})$ distribution at 500 years using these surface complexation constants. In this case, U(VI) transport has increased significantly. This suggests that uncertainty in the surface complexation constants plays in important role in the uncertainty in simulated radionuclide transport. Since sorption data used to develop most surface complexation reactions listed in Tables 2 and 3 are limited, Log $K$ standard deviations are not always reported. However, a $\log K$ standard deviation of 0.5 may be used to approximate uncertainty in these constants and evaluate their effect on reactive transport simulations.

A number of other parameter uncertainties exist in the mechanistic model but are not addressed here (reactive surface area, aqueous speciation constants, surface charging behavior, protonation/deprotonation constants). Thus, our evaluation of U(VI) sorption uncertainty and its effect on reactive transport results is incomplete. However, the results clearly indicate that the uncertainties in the mechanistic model need to be understood and included in transport models. 


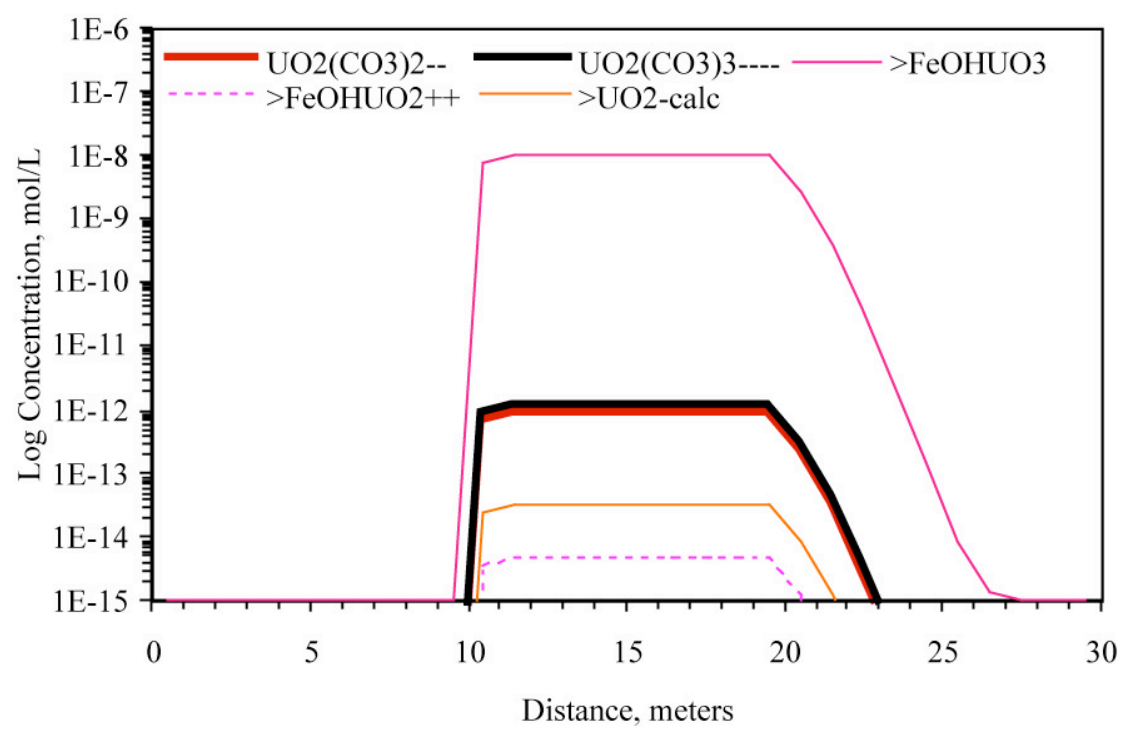

Figure 44. Distribution of dominant $U$ aqueous species and surface complexes at 500 years.

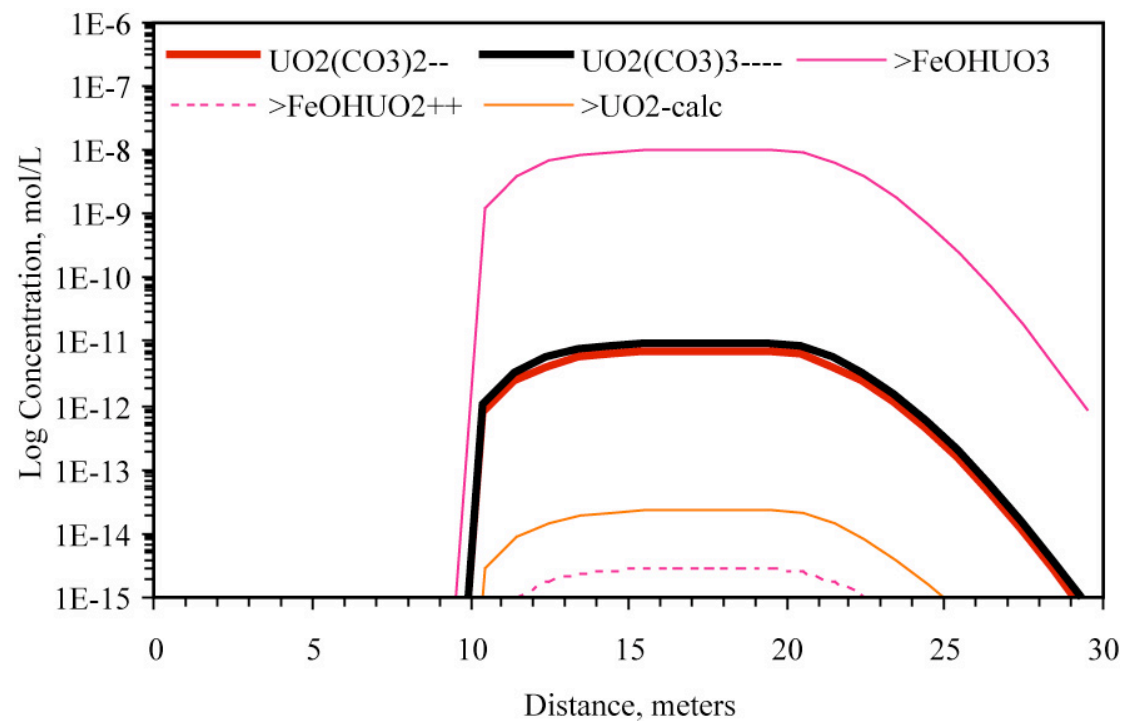

Figure 45. Distribution of dominant $U$ aqueous species and surface complexes at 500 years ( $\log K$ for $U$ sorption on calcite and iron oxide reduced by 1 ). 


\section{CONCLUSIONS}

The one-site NEM constants fit to published data provide a robust description of sorption reactions likely to control radionuclide migration, though some limitations to this approach were observed. For Sr(II) and Eu(III) sorption to iron oxides, reliable prediction of sorption over a very large range of surface loads requires a more complex surface complexation model (addition of an electrostatic term and/or multiple surface sites). Nevertheless, if $\mathrm{Sr}$ (II) or $\mathrm{Eu}(\mathrm{III})$ concentrations in groundwater are not very high (resulting in $<5 \%$ surface load on iron oxide minerals), the one-site NEM constants can adequately predict sorption. Under the conditions used in the $1 \mathrm{D}$ reactive transport simulation, this leads to maximum equilibrium aqueous $\mathrm{Sr}$ (II) and $\mathrm{Eu}$ (III) concentrations of $10^{-4}$ and $2 \times 10^{-7} \mathrm{~mol} / \mathrm{L}$, respectively. Background $\mathrm{Sr}(\mathrm{II})$ concentrations reported by Tompson et al. (1999) for water samples taken from saturated alluvium in Frenchman Flat, NTS, were $<10^{-5} \mathrm{~mol} / \mathrm{L}$ while ${ }^{90} \mathrm{Sr}$ (II) concentrations near the Cambric underground test were $<4 \times 10^{-13} \mathrm{~mol} / \mathrm{L}$ (aqueous ${ }^{155} \mathrm{Eu}$ (III) concentration were $<2 \times 10^{-19} \mathrm{~mol} / \mathrm{L}$ ). Thus, it appears that the one-site NEM can adequately describe the behavior of $\mathrm{Sr}$ (II) and $\mathrm{Eu}(\mathrm{III})$ under these conditions. Unlike Sr(II) and Eu(III), U(VI) sorption to iron oxides could be predicted over a wide range of surface loads and water composition using the one-site $\mathrm{NEM}$. $\mathrm{Np}(\mathrm{V}), \mathrm{Pu}(\mathrm{IV})$, and $\mathrm{Pu}(\mathrm{V})$ sorption to iron oxides as a function of surface load could not be evaluated since only low surface load data was available.

Calcite NEM constants were derived from a very small quantity of newly acquired and published sorption data. For Am(III), sorption data was available only near $\mathrm{pH} \sim 8$. Thus, the fitted NEM constant was not well constrained. However, the resulting NEM constant for Am(III) is consistent with that of Eu(III). This lends some credibility to the Am(III) NEM constant. In general, sorption data for calcite are quite limited when compared to data for iron oxides. The effect of $\mathrm{CO}_{2}$ partial pressure and surface load have not been thoroughly evaluated for any of the radionuclide-calcite reaction pairs of this report.

The NEM database described here can be used to simulate radionuclide behavior, but the limitations of the data should be well understood. Unlike the $K_{d}$ approach, surface complexation constants are intimately associated with the aqueous speciation constants used to derive those constants. The NEM database can, therefore, only be used in conjunction with the modified GEMBOCHS database, as described in Pawloski et al. (2001) and Appendix C. In addition, the uncertainty associated with the mechanistic model needs to be propagated through to radionuclide transport models. The uncertainty associated with the NEM database constants was examined in this report (Figures 43 and 44). A number of other parameter uncertainties exist in the mechanistic model but were not evaluted (e.g. reactive surface area, aqueous speciation constants, surface charging behavior, protonation/deprotonation constants, and possibly others). Nevertheless, our results clearly indicate that the uncertainties in the mechanistic model need to be understood and included in transport models.

Though iron oxide minerals are primary sorbers in many sedimentary environments, calcite can play an important role in radionuclide migration as well. A simple 1D 
reactive transport simulation of radionuclide migration in alluvial sediments was used to evaluate radionuclide-mineral associations. Table 7 is a summary of these key associations; minerals that participate in ion exchange reactions are listed as well. In these 1D simulations, calcite affected the migration of $\mathrm{Am}(\mathrm{III}), \mathrm{Eu}(\mathrm{III}), \mathrm{Np}(\mathrm{V}), \mathrm{Pu}$ (at $\mathrm{O}_{2}(\mathrm{~g})$ fugacity of $10^{-7}$ bars), and $\mathrm{Sm}$. Iron oxide affected the migration of Am(III), $\mathrm{Eu}(\mathrm{III}), \mathrm{Np}(\mathrm{V}), \mathrm{Pu}\left(\mathrm{At}_{2}\right.$ (g) fugacities of 0.2 and $10^{-7}$ bars), and $\mathrm{U}(\mathrm{VI})$. Cs(I) migration was controlled primarily by illite/mica and clinoptilolite ion exchange. Sr(II) migration was controlled primarily by clinoptilolite and smectite ion exchange.

Table 7. Radionuclide-mineral associations considered significant based on 1D reactive transport simulations.

\begin{tabular}{lccccc}
\hline Element & Iron Oxide & Calcite & Smectite & Clinoptilolite & Illite/Mica \\
\hline Tritium $\dagger$ & $\checkmark$ & $\checkmark \S$ & & & \\
Americium & $\checkmark$ & $\checkmark$ & $\checkmark$ & $\checkmark$ & $\checkmark$ \\
Cesium & $\checkmark$ & $\checkmark$ & & & \\
Europium & $\checkmark$ & $\checkmark$ & & & \\
Neptunium & $\checkmark \mathbf{g}$ & $\checkmark$ & & \\
Plutonium & $\checkmark$ & $-\ddagger$ & $\checkmark$ & $\checkmark$ & $\checkmark$ \\
Samarium & $\checkmark$ & - & & & \\
Strontium & Uranium & $\checkmark$ & & & \\
\hline
\end{tabular}

$\dagger$ Migration of tritium was assumed to be unimpeded by sorption reactions.

\$ The "—"indicates that the association was considered but was found to be relatively insignificant.

$\S$ The " $\checkmark$ " indicates that the association will significantly retard element migration.

I $\mathrm{Sm}(\mathrm{III})$ reaction with iron oxide was assumed to be equivalent to the reaction of Eu(III) with iron oxide. 


\section{ACKNOWLEDGEMENTS}

This work was conducted under the auspices of the U. S. Department of Energy by Lawrence Livermore National Laboratory under contract W-7405-Eng-48. This work was funded by the Underground Test Area Project, U.S. Department of Energy, National Nuclear Security Administration, Nevada Site Office. 


\section{REFERENCES}

Bethke, C.M., 1998. The Geochemist's Workbench: Release 3.0. University of Illinois, Urbana-Champaign.

Bradbury, M.H. and Baeyens, B., 1997. A mechanistic description of Ni and Zn sorption on Na- montmorillonite .2. Modeling. Journal of Contaminant Hydrology, 27(34): 223-248.

Carroll, S.A. and Bruno, J., 1991. Mineral-solution interactions in the U(VI)- $\mathrm{CO}_{2}-\mathrm{H}_{2} \mathrm{O}$ system. Radiochimica Acta, 52-3(P1): 187-193.

Catalette, H., Dumonceau, J. and Ollar, P., 1998. Sorption of cesium, barium, and europium on magnetite. Journal of Contaminant Hydrology, 35: 151-159.

Cowan, C.E., Zachara, J.M. and Resch, C.T., 1990. Solution ion effects on the surface exchange of selenite on calcite. Geochimica et Cosmochimica Acta, 54(8): 22232234.

Cromieres, L., 1996. Sorption D'Element Lourds (U(VI), Np(V), Th(IV), Am(III), Co(II), Cs(I), I(-I)) sur des Colloides D'Hematite. Propositions de Mecanismes

Reactionnels, University do Paris-Sud, Orsay, France, 259 pp.

Davis, J.A., Coston, J.A., Kent, D.B. and Fuller, C.C., 1998. Application of the surface complexation concept to complex mineral assemblages. Environmental Science \& Technology, 32(19): 2820-2828.

Davisson, M.L., G.F. Eaton, N.L. Hakem, G.B. Hudson, I.D. Hutcheon, C.A. Laue, A.B. Kersting, J.M. Kenneally, J.E. Moran, D.L. Phinney, T.P. Rose, D.K. Smith, E.R. Sylwester, L. Wang, R. Williams, and M. Zavarin. 2002. Hydrologic Resources Management Program and Underground Test Area Project FY2000 Progress Report (Rose, T.P. G.F. Eaton, and R.I. Yamamoto, Eds.)., Lawrence Livermore National Laboratory, UCRL-ID-145167, Livermore, California.

Doner, H.E. and Zavarin, M., 1997. The role of carbonates in trace and minor element chemistry. In: K. Auerswald, J.M. Bigham and H. Stanjek (Editors), Soils and environment : soil processes from mineral to landscape scale. Catena Verlag, Reiskirchen, Germany, pp. 422.

Duff, M.C. and Amrhein, C., 1996. Uranium(VI) adsorption on goethite and soil in carbonate solutions. Soil Science Society of America Journal, 60(5): 1393-1400.

Dzombak, D.A. and Morel, F.M.M., 1990. Surface complexation modeling : hydrous ferric oxide. Wiley, New York, xvii, 393 pp.

Fujita, T. and Tsukamoto, M., 1997. Influence of carbonate ions on europium sorption onto iron-oxides, Materials Research Society Symposium. Material Research Society, pp. 781-788.

Ginzburg, F.L. and Maksimov, V.F., 1975. Concentration of plutonium(IV) and europium by coprecipitation with calcium carbonate. Soviet Radiochemistry, 17: 1-6.

Girvin, D.C., Ames, L.L., Schwab, A.P. and McGarrah, J.E., 1991. Neptunium adsorption on synthetic amorphous Iron oxyhydroxide. Journal of Colloid and Interface Science, 141(1): 67-78.

Helgeson, H. C. 1969. Thermodynamics of hydrothermal systems at elevated temperatures and pressures, American Journal of Science 267: 729-804. 
Herbelin, A.L. and Westall, J.C., 1994. FITEQL, A computer program for determination of chemical equilibrium constants from experimental data. Department of Chemistry, Oregon State University.

Hsi, C.D. and Langmuir, D., 1985. Adsorption of uranyl onto ferric oxyhydroxides; application of the surface complexation site-binding model. Geochimica et Cosmochimica Acta, 49(9): 1931-1941.

Huysen, K. and van der Laan, J., 1992. DataTheif. National Institute for Nuclear Physics and High Energy Physics, Amsterdam.

Johnson, J.W. and Lundeen, S.R., 1997. GEMBOCHS thermodynamic datafiles for use with the EQ3/6 modeling package, internal report. Lawrence Livermore National Laboratory, Livermore.

Keeney-Kennicutt, W.L. and Morse, J.W., 1984. The interaction of $\mathrm{Np}(\mathrm{V}) \mathrm{O}_{2}{ }^{+}$with common mineral surfaces in dilute aqueous solutions and seawater. Marine Chemistry, 15: 133-150.

Keeney-Kennicutt, W.L. and Morse, J.W., 1985. The redox chemistry of $\mathrm{Pu}(\mathrm{V}) \mathrm{O}_{2}^{+}$ interaction with common mineral surfaces in dilute solutions and seawater. Geochimica et Cosmochimica Acta, 49(12): 2577-2588.

Kinniburgh, D.G., Syers, J.K. and Jackson, M.L., 1975. Specific adsorption of trace amounts of calcium and strontium by hydrous oxides of iron and aluminum. Soil Science Society of America Journal, 39(3): 464-469.

Koeppenkastrop, D. and Decarlo, E.H., 1992. Sorption of Rare-Earth Elements From Seawater Onto Synthetic Mineral Particles - an Experimental Approach. Chemical Geology, 95(3-4): 251-263.

Kolarik, Z., 1961. Sorption radioaktiver isotopen an neiderschlagen. CI. System eisen(III)-hydroxyd-strontiumnitratlosung und die allgemeinen gesetzmessigkeiten der sorption am eisen(III)-hydroxyd. Collection of Czech Chemical Communications, 27: 938-949.

Kurbatov, M.H., Wood, G.B. and Kurbatov, J.D., 1951. Isothermal adsorption of cobalt from dilute solutions. Journal of Physical Chemistry, 55: 1170-1182.

Ledin, A., Karlsson, S., Duker, A. and Allard, B., 1994. The adsorption of europium to colloidal iron oxyhydroxides and quartz - The impact of $\mathrm{pH}$ and an aquatic fulvic acid. Radiochimica Acta, 66-7: 213-220.

Lemire, R. J., Fuger, J., Spahiu, K., Nitsche, H., Ullman, W. J., Potter, P., Vitorge, P., Rand, M. H., Wanner, H., and Rydberg, J. (2001) Chemical Thermodynamics of Neptunium and Plutonium, Vol. 4, Elsevier, New York. Meece, D.E. and Benninger, L.K., 1993. The coprecipitation of $\mathrm{Pu}$ and other radionuclides with $\mathrm{CaCO}_{3}$. Geochimica et Cosmochimica Acta, 57(7): 1447-1458.

Mucci, A. and Morse, J.W., 1983. The incorporation of $\mathrm{Mg}^{2+}$ and $\mathrm{Sr}^{2+}$ into calcite overgrowths; influences of growth rate and solution composition. Geochimica et Cosmochimica Acta, 47(2): 217-233.

Nakayama, S. and Sakamoto, Y., 1991. Sorption of neptunium on naturally-occurring iron-containing minerals. Radiochimica Acta, 52-3(P1): 153-157. 
Pawloski, G.A., Tompson, A.F.B. and Carle, S.F., eds., 2001. Evaluation of the Hydrologic Source Term for Underground Nuclear Tests on Pahute Mesa and the Nevada Test Site: The Cheshire Test, Contributors: W.L. Bourcier, C.J. Bruton, S.F. Carle, J.I. Daniels, R.M. Maxwell, G.A. Pawloski, D.E. Shumaker, D.K. Smith, A.F.B. Tompson, and M. Zavarin., UCRL-ID-147023, Lawrence Livermore National Laboratory, Livermore, California.

Pingitore, N.E., Jr., 1986. Modes of coprecipitation of $\mathrm{Ba}^{2+}$ and $\mathrm{Sr}^{2+}$ with calcite. In: J.A. Davis and K.F. Hayes (Editors), Geochemical processes at mineral surfaces. ACS Symposium Series, pp. 574-586.

Pingitore, N.E., Jr. and Eastman, M.P., 1986. The coprecipitation of $\mathrm{Sr}^{2+}$ with calcite at 25 degrees $C$ and 1 atm. Geochimica et Cosmochimica Acta, 50(10): 2195-2203.

Rabung, T., Geckeis, H., Kim, J. and Beck, H.P., 1998. Sorption of Eu(III) on a natural Hematite: Application of a surface complexation model. Journal of Colloid and Interface Science, 208: 153-161.

Robinson, W.L., Conrado, C.L., Hamilton, T.F. and Stoker, A.C., 1998. The effect of carbonate soil on the transport and dose estimates from long-lived radionuclides at U.S. Pacific Test Sites. UCRL-JC-130231, Lawrence Livermore National Laboratory, Livermore, CA.

Sanchez, A.L., Murray, J.W. and Sibley, T.H., 1985. The adsorption of plutonium IV and V on goethite. Geochimica et Cosmochimica Acta, 49(11): 2297-2307.

Shanbhag, P.M. and Morse, J.W., 1982. Americium interaction with calcite and aragonite surfaces in seawater. Geochimica et Cosmochimica Acta, 46(2): 241-246.

Steefel, C.I. and Yabusaki, S.B., 1995. OS3D/GIMRT, Software for modeling multicomponent-multidimensional reactive transport, User manual and programmer's guide. Pacific Northwest National Laboratory, Richland, WA.

Stumm, W., 1992. Chemistry of the solid-water interface. John Wiley and Sons, Inc., New York, 428 pp.

Sun, X., Doner, H.E. and Zavarin, M., 1998. Spectroscopy study of arsenite [As(III)] oxidation on Mn-substituted goethite. Clays and Clay Minerals, 47(4): 474-480.

Terakado, Y. and Masuda, A., 1988. The coprecipitation of rare-earth elements with calcite and aragonite. Chemical Geology, 69: 103-110.

Tompson, A.F.B., Bruton, C.J. and Pawloski, G.A., 1999. Evaluation of the hydrologic source term from the underground nuclear tests in Frenchman Flat and the Nevada Test Site: The CAMBRIC test. UCRL-ID-132300, Lawrence Livermore National Laboratory, Livermore.

Torstenfelt, B., Andersson, K. and Allard, B., 1982. Sorption of strontium and cesium on rocks and minerals. Chemical Geology, 36: 123-137.

Triay, I.R., Cotter, C.R., Huddleston, M.H., Leonard, D.E., Weaver, S.C., Chipera, S.J., Bish, D.L., Meijer, A.R. and Canepa, J.A., 1996. Batch sorption results for neptunium transport through Yucca Mountain Tuffs. LA-12961-MS, Los Alamos National Laboratory, Los Alamos, New Mexico.

Turner, D.R., 1995. A uniform approach to surface complexation modeling of radionuclide sorption. CNWRA 95-001, Center for Nuclear Waste Regulatory Analyses, San Antonio, Texas. 
Van Cappellen, P., Charlet, L., Stumm, W. and Wersin, P., 1993. A surface complexation model of the carbonate mineral-aqueous solution interface. Geochimica et Cosmochimica Acta, 57: 3505-3518.

Viani, B.E. and Bruton, C.J., 1992. Modeling fluid-rock interaction at Yucca Mountain, Nevada: A progress report. UCRL-ID-109921, Lawrence Livermore National Laboratory, Livermore, California.

Viani, B.E. and Bruton, C.J., 1996. Assessing the role of cation exchange in controlling groundwater chemistry during fluid mixing in fractured granite at Aspo, Sweden. UCRL-JC-121527, Lawrence Livermore National Laboratory, Livermore, California.

Viani, B.E. and Torretto, P.C., 1998. Sorption and transport of uranium on hematite. UCRL-ID-129848, Lawrence Livermore National Laboratory, Livermore, California.

Waite, T.D., Davis, J.A., Payne, T.E., Waychunas, G.A. and Xu, N., 1994. Uranium(VI) adsorption to ferrihydrite - Application of a surface complexation model. Geochimica et Cosmochimica Acta, 58(24): 5465-5478.

Zachara, J.M., Cowan, C.E. and Resch, C.T., 1991. Sorption of divalent metals on calcite. Geochimica et Cosmochimica Acta, 55(6): 1549-1562.

Zachara, J.M., Cowan, C.E. and Resch, C.T., 1993. Metal cation/anion adsorption on calcite carbonate. In: H.E. Allen, E.M. Perdue and D.S. Brown (Editors), Metals in groundwater. Lewis Publishers, Boca Raton, pp. 37-71.

Zachara, J.M., Kittrick, J.A. and Harsh, J.B., 1988. The mechanism of Zn2+ adsorption on calcite. Geochimica et Cosmochimica Acta, 52(9): 2281-2291.

Zachara, J.M., Resch, C.T. and Smith, S.C., 1994. Influence of humic substances on $\mathrm{Co} 2+$ sorption by a subsurface mineral separate and its mineralogic components. Geochimica et Cosmochimica Acta, 58(2): 553-566.

Zavarin, M. and Bruton, C.J. 2004. A Non-Electrostatic Surface Complexation Approach to Modeling Radionuclide Migration and the Nevada Test Site: Aluminosilicates. UCRL-ID-141840, Lawrence Livermore National Laboratory, Livermore, California.

Zhong, S.J. and Mucci, A., 1995. Partitioning of rare earth elements (REEs) between calcite and seawater solutions at 25-degrees-C and 1 atm, and high dissolved REE concentrations. Geochimica et Cosmochimica Acta, 59(3): 443-453. 


\section{APPENDIX A. REPORT ON SORPTION DATA COLLECTED FOR THE UGTA PROGRAM IN FY 2000}

The following text is a copy of an internal report delivered to the UGTA program in FY 2000. The internal report has been included in its entirety and without changes. This report contains a description of the methods and results of several batch sorption experiments performed in FY 2000 for the UGTA program. These data were used in developing the surface complexation constants listed in Tables 4 for radionuclide sorption to calcite. A discussion of these data is presented in the main text of this report. 


\title{
Radionuclide Sorption to Zeolite and Calcite: Laboratory Experiments and Modeling
}

\author{
M. Zavarin and S. K. Roberts
}

The information presented here is a summary of two laboratory experimental and sorption modeling efforts performed in FY2000 for the UGTA program. The two tasks were the following:

- A laboratory investigation of $\mathrm{Np}, \mathrm{Eu}$, and $\mathrm{Sm}$ sorption to carbonates.

- A laboratory investigation into the rate-limited availability of ion exchange sites in clinoptilolite for $\mathrm{Eu}, \mathrm{Np}$, and $\mathrm{U}$ relative to $\mathrm{Cs}$ and $\mathrm{Sr}$.

\section{Introduction}

Minerals that can exhibit surface charge (e.g. goethite, calcite, aluminosilicates etc.) can significantly reduce radionuclide $(\mathrm{RN})$ mobility in the environment. The reduced mobility is a result of surface complexation (SC) and ion exchange (IE) reactions. Surface complexation and ion exchange reactions provide a mechanistic approach to modeling sorption and can account for the effect of changing environmental conditions on sorption. In modeling RN migration in the environment, partitioning $K \mathrm{~d}$ constants are often used to model sorption. $K$ d constants are typically reported as a ratio of total sorbed concentration ( $\mathrm{mol} / \mathrm{g}$ ) to total aqueous concentration $(\mathrm{mol} / \mathrm{mL})$. Although the $K \mathrm{~d}$ approach can adequately describe the sorptive behavior of a particular sediment at a particular $\mathrm{pH}$ and solution composition, the many factors that affect $\mathrm{RN}$ sorption in dynamic geologic environments cannot be addressed.

Here, the interaction of several radionuclides with heulandite (a zeolite similar to clinoptilolite) and calcite are examined. The results are intended to improve our sorption modeling database for use in near field reactive transport modeling for the UGTA program. Heulandite sorption was modeled using both the non-electrostatic and the diffuse layer surface complexation models. Calcite sorption was modeled using the nonelectrostatic surface complexation model and the Vanselow and Gapon ion exchange models. A description of these models is presented below and justification for their use is discussed in the methods section of this report. Consistency with published data are discussed as well.

\subsection{Surface Complexation}

Surface complexation (SC) reactions involve mineral surface functional groups and aqueous species. A typical SC reaction and associated equilibrium constant can be written in the following manner:

$>\mathrm{SiOH}+\mathrm{Pu}^{4+} \Leftrightarrow>\mathrm{SiOPu}^{3+}+\mathrm{H}^{+}$ 
$\mathrm{K}=\frac{\left(>\mathrm{SiOPu}^{3+}\right)\left(\mathrm{H}^{+}\right)}{(>\mathrm{SiOH})\left(\mathrm{Pu}^{4+}\right)}$

where $>\mathrm{SiOH}$ is a surface functional group (on a silicate mineral), $\mathrm{Pu}^{4+}$ is an aqueous plutonium species that reacts with the surface (to form $>\mathrm{SiOPu}^{3+}$ ), and $\mathrm{H}^{+}$is released as a result of the reaction. Just as for simple aqueous complexation reactions, the above SC reaction has an equilibrium reaction constant, $K$, that describes the relative activity of all species at equilibrium.

Factors that influence surface complexation on a particular mineral include:

- Surface area

- $\mathrm{pH}$

- Aqueous complexation

- Ionic strength

- Surface charge

Since sorption reactions occur at the mineral-water interface, sorption will be dependent on the mineral surface area available for reaction. The $\mathrm{pH}$ can significantly affect sorption as well. For example, in Equation 1, as the concentration of $\mathrm{H}^{+}$increases, a larger fraction of $\mathrm{Pu}^{4+}$ will remain in solution. Surface functional groups (e.g. $>\mathrm{SiOH}$ ) may also become protonated/deprotonated as a function of $\mathrm{pH}$ and affect sorption. Aqueous complexation will influence the concentration of aqueous species in solution; this may increase or decrease sorption depending on the species involved in the reactions. For example, uranium sorption decreases as a function of carbonate concentration in solution due to the formation of uranyl carbonate complexes (Duff and Amrhein, 1996). Ionic strength may influence sorption by reducing the effective concentration (i.e. activity) of aqueous species and affect the charging behavior of the surface. Surface complexes as well as surface protonation and deprotonation can also affect the charging of the surface which will, in turn, influence sorption. Unlike $K \mathrm{~d}$ values, $\mathrm{SC}$ reactions can, ideally, account for all factors that influence the ratio of sorbed to aqueous RN concentrations. Because SC reactions account for changes in environmental conditions, they provide a much more robust basis for simulating $\mathrm{RN}$ sorption.

There are many models that have been used to describe SC reactions (nonelectrostatic, constant capacitance, diffuse layer, triple layer, and others) Here, we fit radionuclide surface complexation using two of the simpler models: the non-electrostatic model (NEM) and the diffuse layer model (DLM). Unlike all other SC models, the NEM (Kurbatov et al., 1951) assumes that surface electrical charge does not affect equilibrium SC reactions. Although the NEM approach over-simplifies the factors affecting SC, several investigators have used this model approach to describe sorption reactions (Bradbury and Baeyens, 1997; Davis et al., 1998; Zachara et al., 1994). Davis et al. (1998) argued that the NEM approach may be the most appropriate for complex environmental applications since the surface charging behavior of non-ideal natural mineral phases is not well known. The electrostatic models typically contain one or 
more parameters that account for surface charge effects. The DLM is one of the simplest electrostatic models and relies on a modified Gouy-Chapman theory to describe the effect of electrostatics on sorption.

\subsection{Ion Exchange}

The permanent charge on some clay minerals is the result of non-charge-balanced ion substitution. For example, the substitution of $\mathrm{Si}^{4+}$ for $\mathrm{Al}^{3+}$ in a clay will result in a permanent negative charge. A permanent negative charge is typically balanced by cations in solution that are attracted to the mineral surface. For example, the aluminosilicate montmorillonite will typically have a permanent negative charge equal to $\sim 800 \mathrm{meq} / \mathrm{kg}$. In soils, the majority of this charge is balanced by the major cations in the waters $\left(\mathrm{Na}^{+}, \mathrm{K}^{+}, \mathrm{Ca}^{2+}\right.$, and $\left.\mathrm{Mg}^{2+}\right)$. When other cations such as $\mathrm{Pu}^{4+}$ are present, they may also become associated with the negatively charged surface via IE. The distribution of cations on surfaces as a result of permanent charge can be described by IE reactions of the following form:

$\mathrm{Na}-\mathrm{X}+\mathrm{Cs}^{+}<==>\mathrm{Cs}-\mathrm{X}+\mathrm{Na}^{+}$

with an associated equilibrium constant :

$\mathrm{K}=\frac{(\mathrm{Cs}-\mathrm{X})\left(\mathrm{Na}^{+}\right)}{(\mathrm{Na}-\mathrm{X})\left(\mathrm{Cs}^{+}\right)}$

where " $X$ " designates a surface association and the four terms in parentheses are the activities of the respective species. For homovalent exchange such as the reaction shown here, the activity of surface-associated species is often assumed to be defined by the relative concentration of each species $\left(\frac{[\mathrm{Cs}-\mathrm{X}]}{[\mathrm{Cs}-\mathrm{X}]+[\mathrm{Na}-\mathrm{X}]}\right.$ and $\left.\frac{[\mathrm{Na}-\mathrm{X}]}{[\mathrm{Cs}-\mathrm{X}]+[\mathrm{Na}-\mathrm{X}]}\right)$. Because the denominators for $\mathrm{Cs}-\mathrm{X}$ and $\mathrm{Na}-\mathrm{X}$ activity are identical, the activity ratio of surface species can be simplified to the total mol ratio of $\mathrm{Cs}$ and $\mathrm{Na}$ associated with the mineral surface. The activity of species in solution are determined from speciation and ionic strength activity corrections. The constant, $K$, describes the relative activity of the various species at equilibrium.

For heterovalent IE, the equilibrium reactions are complicated by the fact that the two exchanging ions balance different amounts of charge on the surface. Heterovalent IE reactions can be written in several forms. For example, by the Gapon convention:

$\mathrm{Na}-\mathrm{X}+0.5 \mathrm{Ca}^{2+}<==>\mathrm{Ca}_{0.5}-\mathrm{X}+\mathrm{Na}^{+}$

with an associated equilibrium constant: 
$\mathrm{K}=\frac{\left(\mathrm{Ca}_{0.5}-\mathrm{X}\right)\left(\mathrm{Na}^{+}\right)}{(\mathrm{Na}-\mathrm{X})\left(\mathrm{Ca}^{2+}\right)^{0.5}}$

In this case, the denominators for surface-associated $\mathrm{Ca}$ and $\mathrm{Na}$ activities are identical and the activity of surface associated species can be simplified to mol-charge (equivalent) concentrations of $\mathrm{Ca}$ and $\mathrm{Na}$. Thus, surface activities are in units of cation equivalents instead of $\mathrm{mol} / \mathrm{L}$ concentrations.

By the Vanselow convention, the heterovalent exchange reaction is written in a different form that relates to the relative mol concentration of surface species instead of relative equivalent concentrations. In this case,

$\mathrm{Na}-\mathrm{X}+0.5 \mathrm{Ca}^{2+}<==>0.5 \mathrm{Ca}-\mathrm{X}_{2}+\mathrm{Na}^{+}$

with an associated equilibrium constant of the form:

$\mathrm{K}=\frac{\left(\mathrm{Ca}-\mathrm{X}_{2}\right)^{0.5}\left(\mathrm{Na}^{+}\right)}{(\mathrm{Na}-\mathrm{X})\left(\mathrm{Ca}^{2+}\right)^{0.5}}$

The two terms in the above equation that relate to surface species activity are determined by:

$\left(\frac{\left[\mathrm{Ca}-\mathrm{X}_{2}\right]}{\left(\left[\mathrm{Ca}-\mathrm{X}_{2}\right]+[\mathrm{Na}-\mathrm{X}]\right)}\right)^{0.5}$ and $\left(\frac{[\mathrm{Na}-\mathrm{X}]}{\left[\left[\mathrm{Ca}-\mathrm{X}_{2}\right]+[\mathrm{Na}-\mathrm{X}]\right)}\right)$

where the terms in the brackets relate to $\mathrm{mol} / \mathrm{L}$ concentrations. By the Vanselow convention, the activity of the surface species cannot be simplified to equivalent concentrations or $\mathrm{mol} / \mathrm{L}$ concentrations of the two surface species because the denominator cannot be canceled out.

A special case of the Vanselow convention is when only a trace quantity of one exchanging species is likely to be associated with the mineral surface. For example, if one assumes that only a trace quantity of $\mathrm{Na}$ will be associated with the surface, the above Vanselow equation can be simplified to: 


$$
\begin{gathered}
\mathrm{K}=\frac{\left(\mathrm{Ca}-\mathrm{X}_{2}\right)^{0.5}\left(\mathrm{Na}^{+}\right)}{(\mathrm{Na}-\mathrm{X})\left(\mathrm{Ca}^{2+}\right)^{0.5}}=\frac{\left(\frac{\left.\mathrm{Ca}-\mathrm{X}_{2}\right]}{\left[\mathrm{Ca}-\mathrm{X}_{2}\right]+[\mathrm{Na}-\mathrm{X}]}\right)^{0.5}\left(\mathrm{Na}^{+}\right)}{\left(\frac{[\mathrm{Na}-\mathrm{X}]}{\left[\mathrm{Ca}-\mathrm{X}_{2}\right]+[\mathrm{Na}-\mathrm{X}]}\right)\left(\mathrm{Ca}^{2+}\right)^{0.5}} \\
\cdots=\frac{\left(\frac{\left[\mathrm{Ca}-\mathrm{X}_{2}\right]}{\left[\mathrm{Ca}-\mathrm{X}_{2}\right]}\right)^{0.5}\left(\mathrm{Na}^{+}\right)}{\left(\frac{[\mathrm{Na}-\mathrm{X}]}{\left[\mathrm{Ca}-\mathrm{X}_{2}\right]}\right)\left(\mathrm{Ca}^{2+}\right)^{0.5}}=\frac{\left[\mathrm{Ca}-\mathrm{X}_{2}\right]\left(\mathrm{Na}^{+}\right)}{[\mathrm{Na}-\mathrm{X}]\left(\mathrm{Ca}^{2+}\right)^{0.5}}
\end{gathered}
$$

which is equivalent, in form, to the Gapon equation except that mol/L concentrations of the surface species are used instead of equivalent concentrations.

\section{Methods}

\subsection{Data Fitting Routine and Aqueous Speciation Data}

Sorption data were fitted using a modified version of the fitting program FITEQL (Herbelin and Westall, 1994). The code was modified to allow for:

- Automated activity correction using the extended Debye Huckel model

- Automated retrieval of aqueous speciation data from a database

- An ion exchange capability

- Code stability in cases of large species matrices. ${ }^{11}$

Aqueous speciation constants were based on the GEMBOCHS thermodynamic data base version data.com.V8.R6 (Johnson and Lundeen, 1997) with revisions as noted in Tompson et al. (1999) and in the text below.

Table 1 contains the complexation constants used for $\mathrm{Sm}(\mathrm{III}), \mathrm{Eu}(\mathrm{III})$, and $\mathrm{Np}(\mathrm{V})$ speciation. These data were culled from a larger set of complexation constants; only the most significant species with respect to our sorption modeling are listed here. $\mathrm{Np}(\mathrm{V})$ sorption data have been collected but modeling has not yet been completed and, thus, is not presented here. Our literature search suggests the U(VI) will not be a strong sorber to zeolites and the possible diffusion into inner channels of zeolite is still under investigation.

\footnotetext{
${ }^{11}$ A report regarding the modification of the FITEQL source code is attached to the end of this report. The FITEQL source code modification comprises the third FY2000 UGTA task.
} 


\subsection{Heulandite Sorption Data and Modeling}

Batch sorption experiments for RN sorption to heulandite were performed in low and high ionic strength groundwater to discern surface complexation from ion exchange sorption mechanisms. Solutions were equilibrated with atmospheric $\mathrm{CO}_{2}$ in all cases. Major ion speciation for the low ionic strength groundwater is presented in Figure 1. At low $\mathrm{pH}$, groundwater composition is relatively constant but, at high $\mathrm{pH}$, carbonate alkalinity increases exponentially as a function of $\mathrm{pH}$. This can often result in a decrease in $\mathrm{RN}$ sorption, as will be shown below.

Heulandite $\left.\left(\left(\mathrm{Ca}, \mathrm{Na}_{2}\right) \mathrm{Al}_{2} \mathrm{Si}_{7} \mathrm{O}_{18} * 6 \mathrm{H}_{2} \mathrm{O}\right)\right)$ mineral was generously donated by Thrainn Fridriksson, a graduate student of the Department of Geological and Environmental Sciences at Stanford University. Electron microprobe measurements revealed a major element composition of $\mathrm{Si}_{6.8} \mathrm{Al}_{2.24} \mathrm{Ca}_{0.89} \mathrm{Na}_{0.2} \mathrm{~K}_{0.12}$ and XRD measurements revealed a minor contaminant of epistilbite. The $\sim 10$ micron particle fraction was isolated (Figures 2 and 3) and the surface area was measured by BET (3.71 $\left.\mathrm{m}^{2} / \mathrm{g}\right)$.

Table 1. Species used in surface complexation fits.

\begin{tabular}{llllllll}
\hline Species & $\log K$ & $\#$ & Component & \# & Component & \# & Component \\
\hline $\mathrm{Eu}(\mathrm{CO} 3) 2-$ & -7.67 & -2 & $\mathrm{H}+$ & 1 & $\mathrm{Eu}+++$ & 2 & $\mathrm{HCO}-$ \\
$\mathrm{Eu}(\mathrm{CO} 3) 3-$ & -18.49 & -3 & $\mathrm{H}+$ & 1 & $\mathrm{Eu}+++$ & 3 & $\mathrm{HCO}-$ \\
$\mathrm{Eu}(\mathrm{OH}) 2+$ & -14.86 & -2 & $\mathrm{H}+$ & 1 & $\mathrm{Eu}+++$ & 2 & $\mathrm{H} 2 \mathrm{O}$ \\
$\mathrm{Eu}(\mathrm{OH}) 3(\mathrm{aq})$ & -24.13 & -3 & $\mathrm{H}+$ & 1 & $\mathrm{Eu}+++$ & 3 & $\mathrm{H} 2 \mathrm{O}$ \\
$\mathrm{EuOH}++$ & -7.91 & -1 & $\mathrm{H}+$ & 1 & $\mathrm{Eu}+++$ & 1 & $\mathrm{H} 2 \mathrm{O}$ \\
$\mathrm{EuCO}+$ & -2.37 & -1 & $\mathrm{H}+$ & 1 & $\mathrm{Eu}+++$ & 1 & $\mathrm{HCO}-$ \\
$\mathrm{EuHCO}++$ & 2.10 & 1 & $\mathrm{Eu}+++$ & 1 & $\mathrm{HCO}-$ & & \\
& & & & & & & \\
$\mathrm{NpO} 2(\mathrm{CO} 3) 2-$ & -13.66 & -2 & $\mathrm{H}+$ & 1 & $\mathrm{NpO} 2+$ & 2 & $\mathrm{HCO}-$ \\
$\mathrm{NpO} 2(\mathrm{CO} 3) 3(5-)$ & -22.49 & -3 & $\mathrm{H}+$ & 1 & $\mathrm{NpO} 2+$ & 3 & $\mathrm{HCO}-$ \\
$\mathrm{NpO} 2 \mathrm{CO} 3-$ & -5.73 & -1 & $\mathrm{H}+$ & 1 & $\mathrm{HCO}-$ & 1 & $\mathrm{NpO} 2+$ \\
$\mathrm{NpO} 2 \mathrm{OH}(\mathrm{aq})$ & -8.90 & -1 & $\mathrm{H}+$ & 1 & $\mathrm{H} 2 \mathrm{O}$ & 1 & $\mathrm{NpO} 2+$ \\
& & & & & & & \\
$\mathrm{Sm}(\mathrm{CO} 3) 2-$ & -7.86 & -2 & $\mathrm{H}+$ & 1 & $\mathrm{Sm}+++$ & 2 & $\mathrm{HCO}-$ \\
$\mathrm{SmCO} 3+$ & -2.48 & -1 & $\mathrm{H}+$ & 1 & $\mathrm{HCO} 3-$ & 1 & $\mathrm{Sm}+++$ \\
$\mathrm{SmOH}++$ & -7.98 & -1 & $\mathrm{H}+$ & 1 & $\mathrm{H} 2 \mathrm{O}$ & 1 & $\mathrm{Sm}+++$ \\
\hline
\end{tabular}


Sorption experiments were performed from $\mathrm{pH} 3$ to $\mathrm{pH} 10$. The $\mathrm{pH}$ was adjusted in the experiments using $\mathrm{HCl}$ or $\mathrm{Na}_{2} \mathrm{CO}_{3}$. A pH-stat was typically used to equilibrate solutions with respect to atmospheric $\mathrm{CO}_{2}$ at high $\mathrm{pH}$. In $\mathrm{Sm}(\mathrm{III})$ and $\mathrm{Eu}(\mathrm{III})$ sorption experiments, $\sim 1 * 10^{-7} \mathrm{~mol} / \mathrm{L} \mathrm{RN}$ was reacted with $1.3 \mathrm{~g} / \mathrm{L}$ heulandite as batch experiments. After 24 hours of reaction, the batch samples were centrifuged and a sample of the supernatant was collected. The sample was then acidified and analyzed by ICP-MS. Samples were centrifuged instead of filtered because loss of the RNs due to sorption to filters was of concern. In $\mathrm{Np}(\mathrm{V})$ sorption experiments, $\sim 1 * 10^{-7} \mathrm{~mol} / \mathrm{L} \mathrm{Np}$ was reacted with $1.35 \mathrm{~g} / \mathrm{L}$ heulandite as batch experiments. After 24 hours of reaction, batch samples were centrifuged and the supernatant collected. The $\mathrm{Np}(\mathrm{V})$ in solution was measured by scintillation counting. Blanks were run in parallel in all experiments. Losses to container walls were minimal (Teflon tubes). For a subset of batch samples, sorption was also measured at $\sim 30$ days to examine whether sorption at long times may increase owing to slow sorption kinetics or other mechanisms.

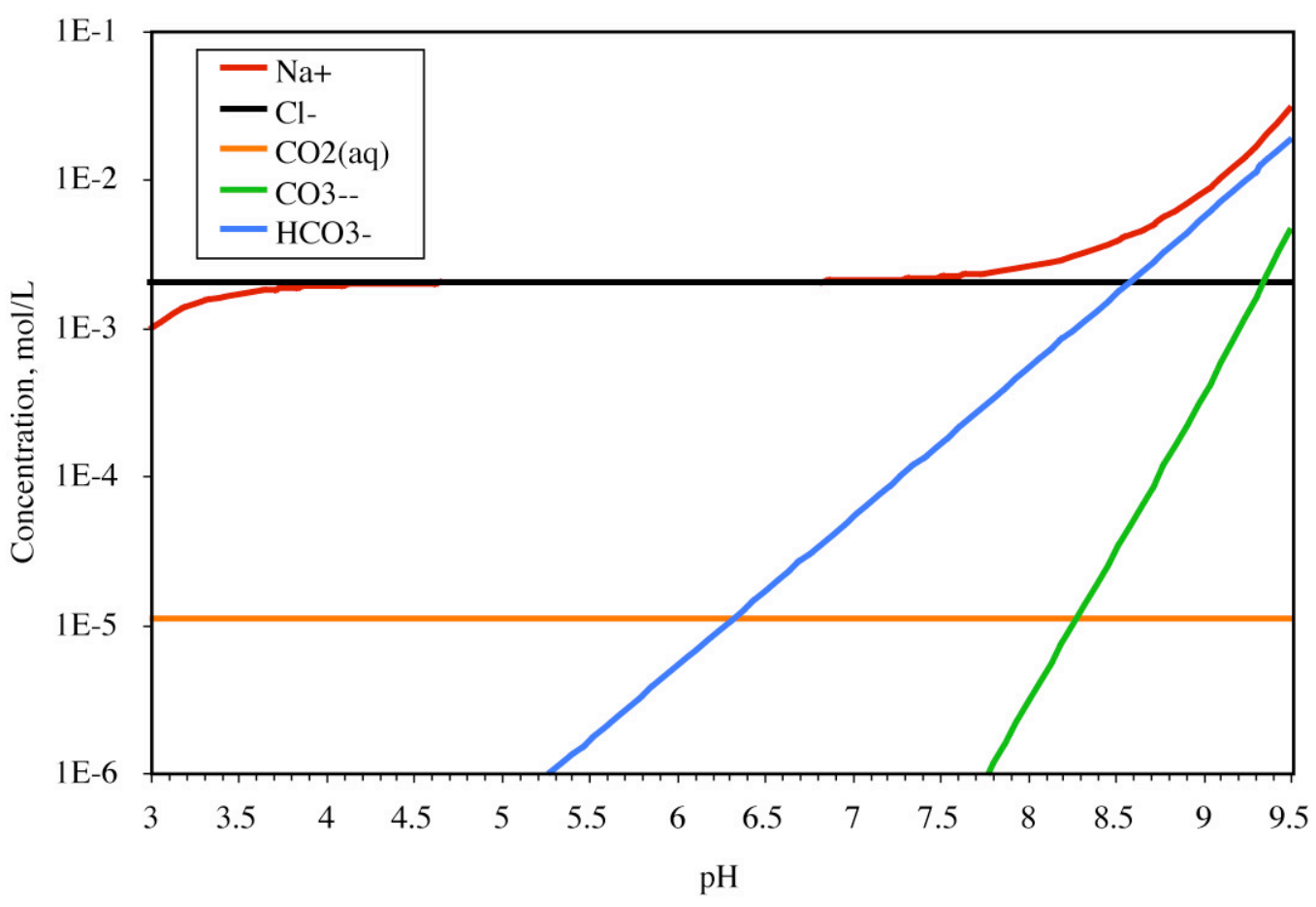

Figure 1. Composition of low ionic strength waters used in heulandite sorption experiments. 


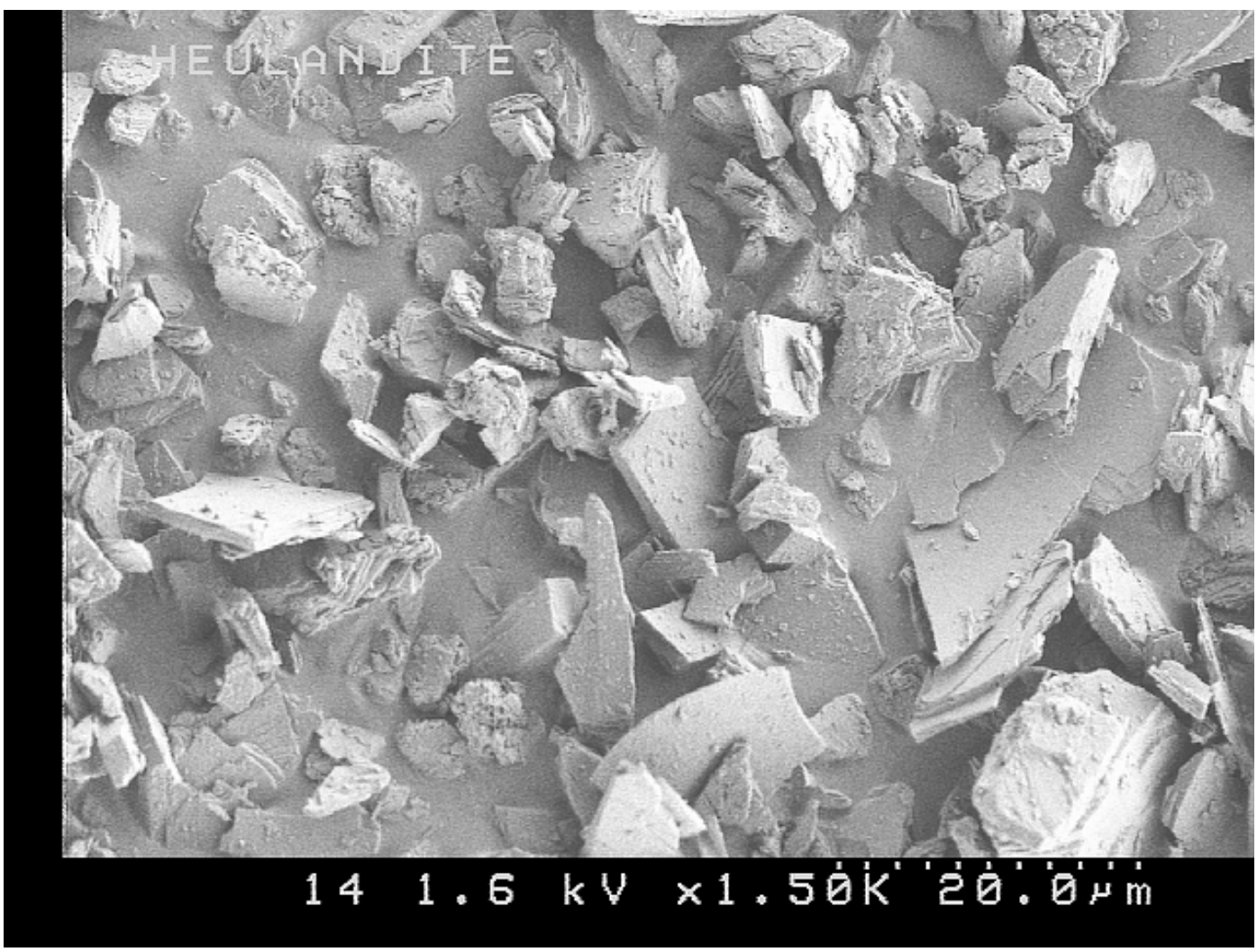

Figure 2. Heulandite SEM photo.

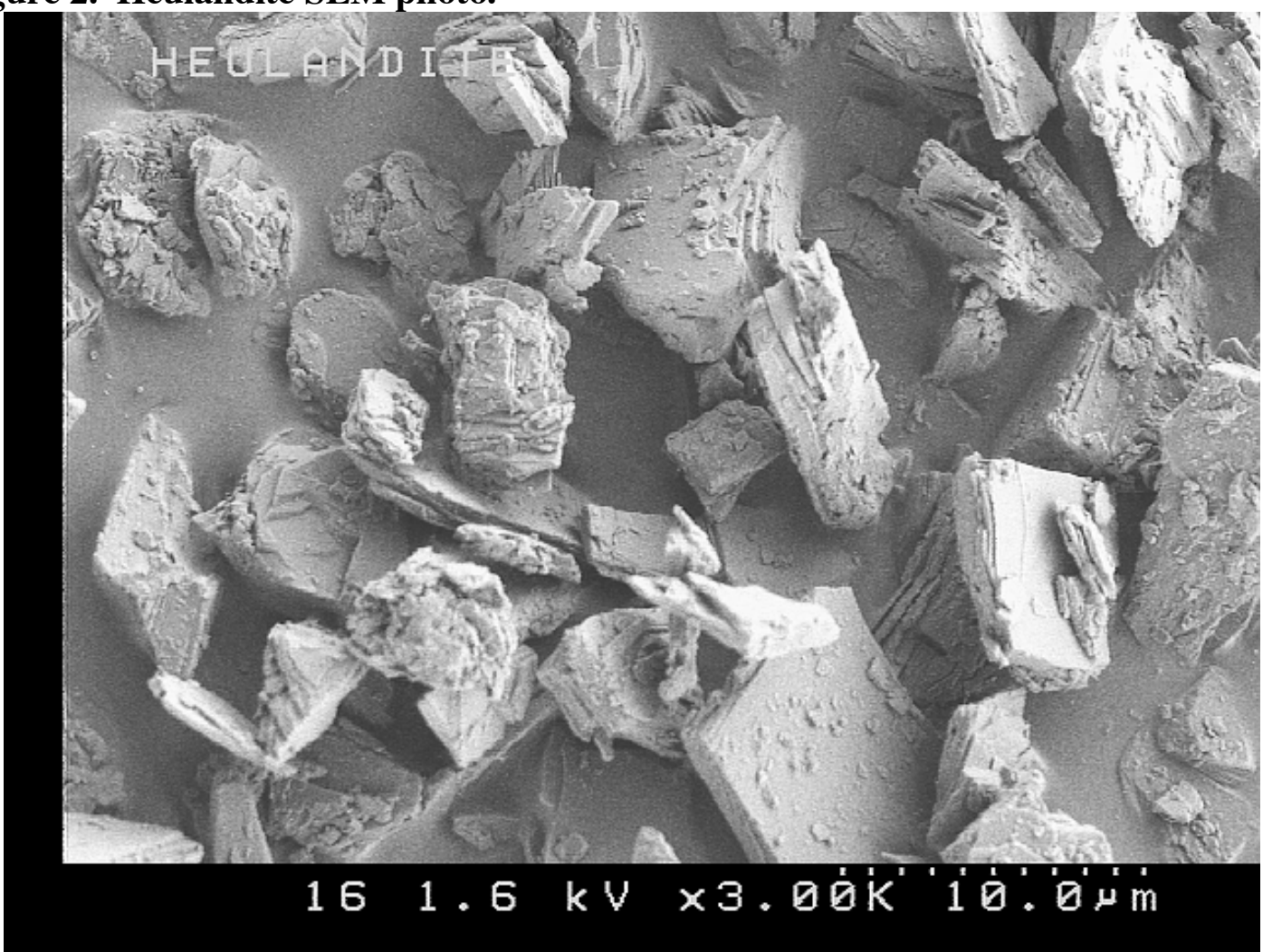

Figure 3. Heulandite SEM photo. 
Figure 4 presents the speciation of $\mathrm{Eu}(\mathrm{III})$ as a function of $\mathrm{pH}$ in a solution comparable with the heulandite sorption experiments. At low $\mathrm{pH}$, the $\mathrm{Eu}^{3+}$ species dominates; at high $\mathrm{pH}$, the carbonate species dominate. Only trace quantities of the hydroxide species are present. Figure 5 presents the speciation of Sm(III). As would be expected, speciation is nearly equivalent to that of $\mathrm{Eu}(\mathrm{III})$.

Figure 6 presents the speciation of $\mathrm{Np}(\mathrm{V})$. Here, the $\mathrm{NpO}_{2}^{+}$species dominates except at the highest $\mathrm{pH}$ where the carbonate species begin to dominate. As in the case of $\mathrm{Sm}(\mathrm{III})$ and $\mathrm{Eu}(\mathrm{III})$, the speciation results suggest that sorption at high $\mathrm{pH}$ may be suppressed by the formation of negatively charged RN-carbonate species. This would be consistent with observations of Duff and Amrhein (1996) and others that aqueous carbonate complexation can effectively compete with sorption for RNs. It is also consistent with our recent modeling of $\mathrm{Pu}(\mathrm{V})$ sorption on calcite which revealed significant sorption suppression at high $\mathrm{pH}$.

Modeling the interaction of Sm(III) and Eu(III) with clinoptilolite was accomplished by fitting the sorption data to a non-electrostatic (NEM) and diffuse layer (DLM) surface complexation models. The possible contribution of ion exchange mechanisms to sorption is discussed below. Several authors have recently shown that sorption of RNs on aluminosilicate minerals can be related to SC on alumina and silica surfaces since surface functional groups are comparable (McKinley et al., 1995; Turner et al., 1996). This generalized aluminosilicate model is used to fit our sorption data here. Thus, aluminol and silanol protonation and deprotonation reactions are assumed to be equivalent to those of silica and alumina, as described in Turner (1995) (log $K^{\prime}$ s for $>\mathrm{AlOH}_{2}{ }^{+},>\mathrm{AlO}^{-}$, and $>\mathrm{SiO}^{-}$are 8.33, -9.73, and -7.20, respectively). For simplicity, the DLM acidity constants for $\mathrm{SiO}_{2}$ and $\alpha-\mathrm{Al}_{2} \mathrm{O}_{3}$ reported by Turner (1995) were used both in the NEM fits and the DLM fits.

In order to retain the most simplified approach to describing the reactive sites on aluminosilicate minerals, several additional simplifying assumption were made. A single type of silanol and aluminol reactive site was used to fit the data. A total site density of 2.31 sites $/ \mathrm{nm}^{2}$ was assumed. This value was taken from Dzombak and Morel (1990) who used this site density for SC modeling of hydrous ferric oxide surfaces. This site density was also used by Turner (1995) for a variety of minerals to minimize the number of fitting parameters and arrive at a uniform set of surface complexation reactions. The ratio of silanol to aluminol surface reactive sites was assumed to be equivalent to their bulk mineral ratio. 


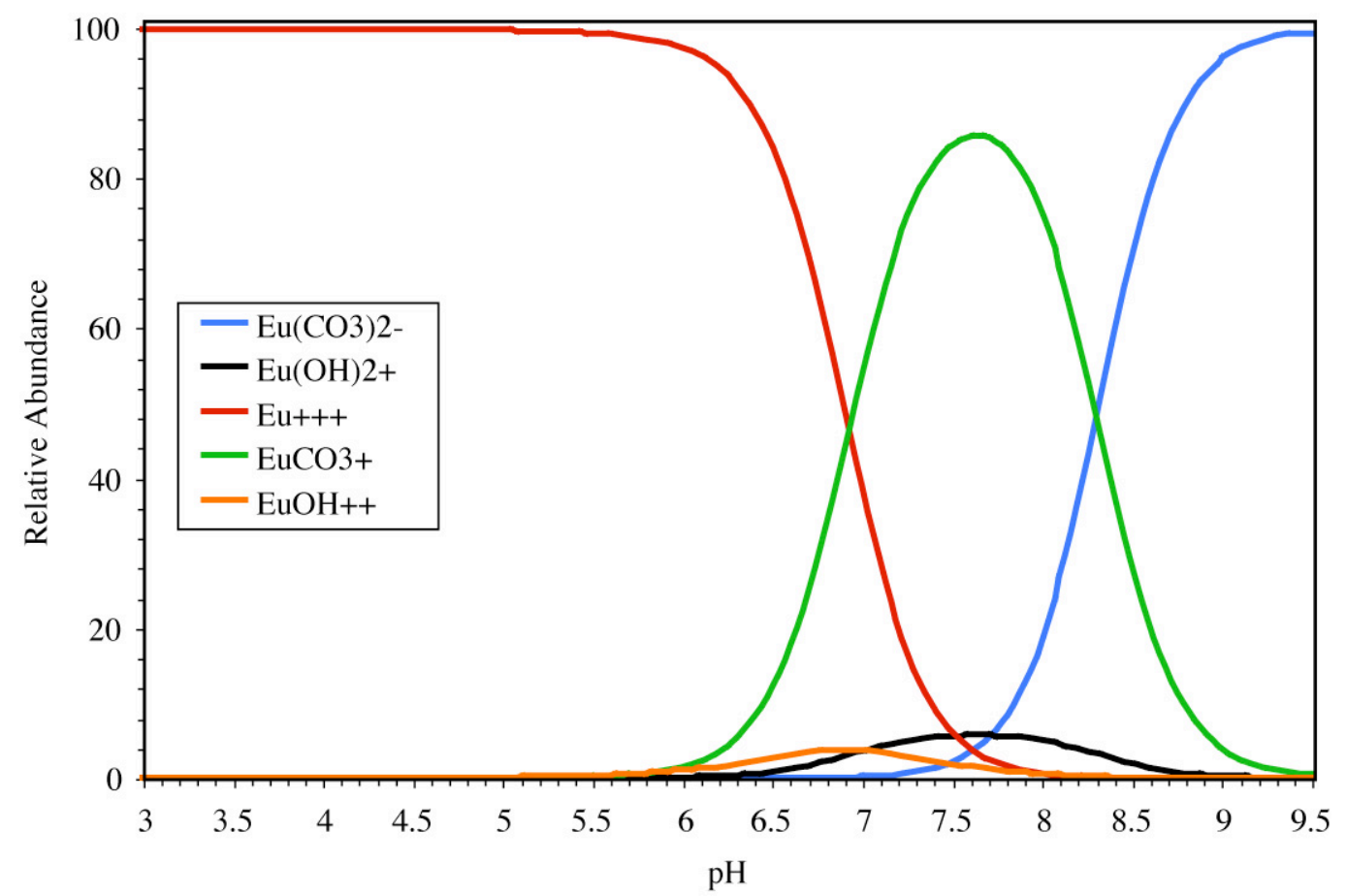

Figure 4. Speciation of Eu(III) under condition of heulandite sorption experiments.

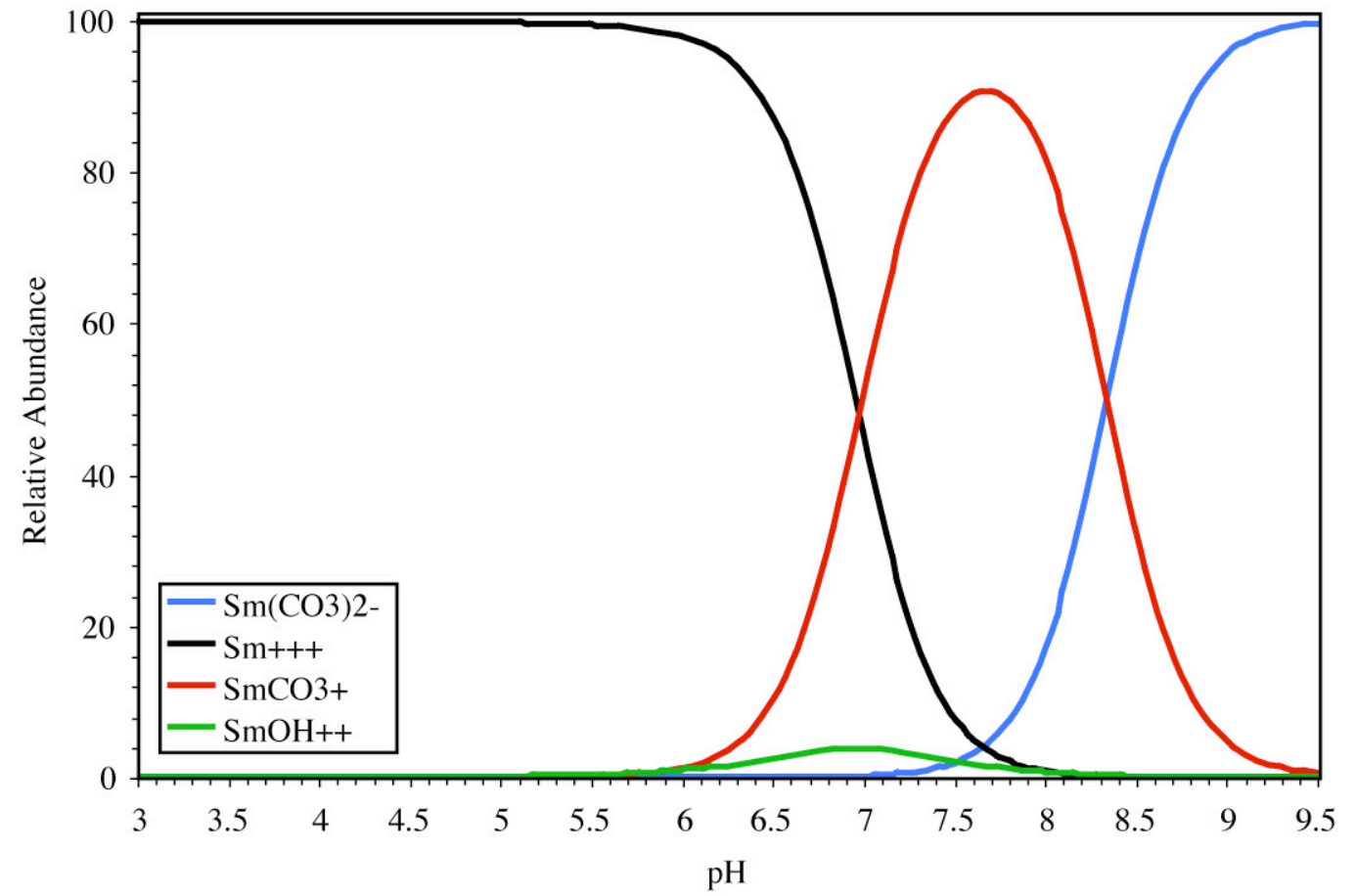

Figure 5. Speciation of Sm(III) under condition of heulandite sorption experiments. 


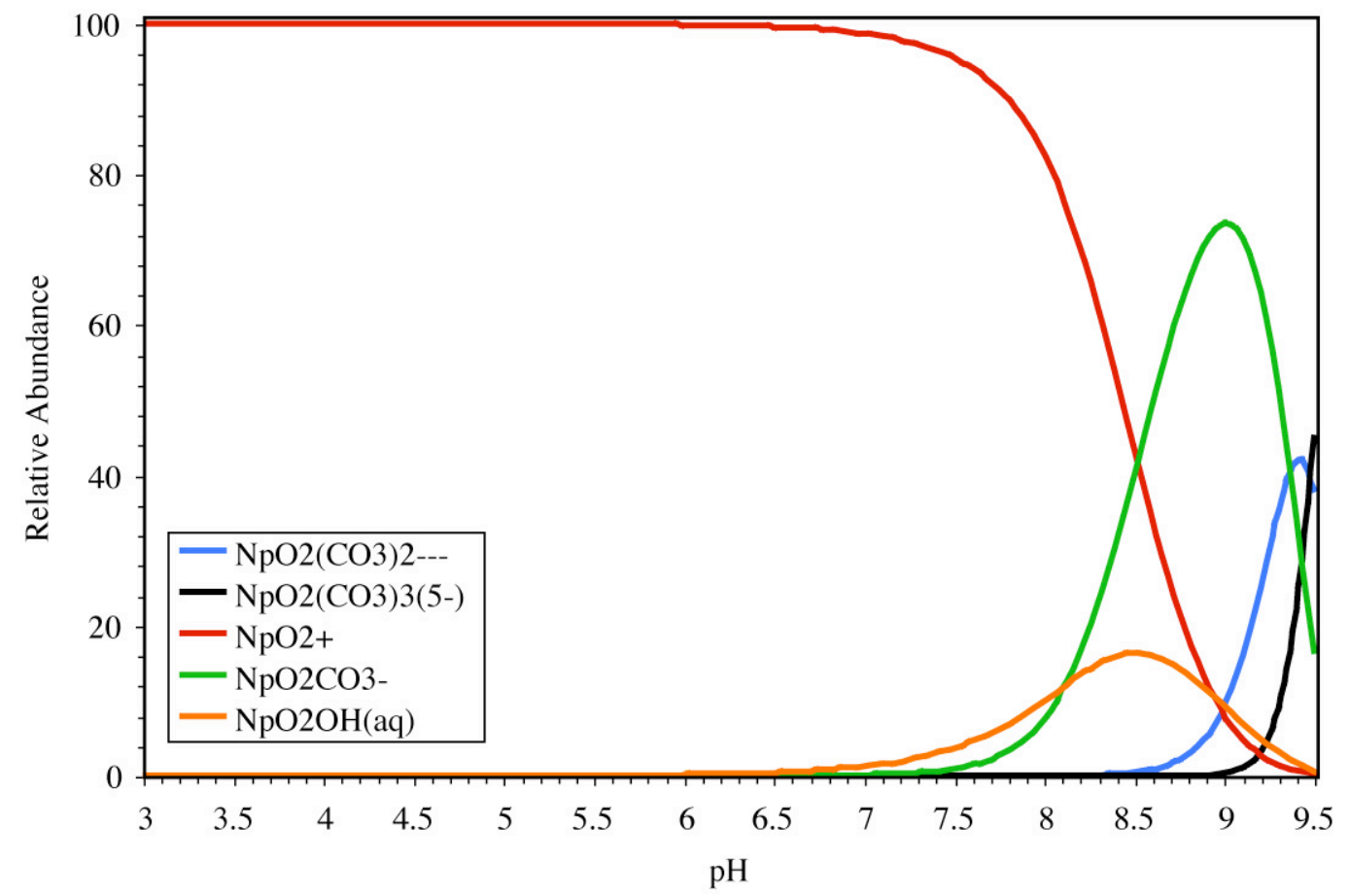

Figure 6. Speciation of $\mathrm{Np}(\mathrm{V})$ under conditions of heulandite sorption experiments.

\subsection{Calcite Sorption Data and Modeling}

Batch sorption experiments for $\mathrm{Sm}(\mathrm{III}), \mathrm{Eu}(\mathrm{III})$, and $\mathrm{Np}(\mathrm{V})$ sorption to calcite were performed in calcite saturated waters equilibrated with atmospheric $\mathrm{CO}_{2}(\mathrm{~g})$ using a $\mathrm{pH}$-stating technique and adjusted to an ionic strength of 0.1 using $\mathrm{NaCl}$. The solutions were equilibrated with calcite mineral prior to sorption experiments to ensure calcite saturation during experiments. Between $\mathrm{pH} 7.5$ and 9.75, the carbonate concentration increases from $2.2 * 10^{-4}$ to $7.3 * 10^{-2} \mathrm{~mol} / \mathrm{L}$ while the $\mathrm{Ca}^{2+}$ concentration decreases from $4.0 * 10^{-2}$ to $8.5 * 10^{-6} \mathrm{~mol} / \mathrm{L}$. The major element composition of batch sorption solutions is presented in Figure 7.

The calcite used in all aspects of the sorption experiments was ACS reagent grade calcite that was equilibrated in a sodium carbonate solution for several months to age the calcite and minimize potential recrystallization effects. The BET surface area was measured $(0.262 \mathrm{~m} 2 / \mathrm{g})$ and SEM photos revealed very regular calcite rhombs that were $\sim 10$ micrometers in size (Figure 8 ).

Sorption experiments were performed from $\mathrm{pH} 7.5$ to $\mathrm{pH} 9.75$. For $\mathrm{Sm}(\mathrm{III})$ and $\mathrm{Eu}(\mathrm{III}), \sim 1 * 10^{-7} \mathrm{~mol} / \mathrm{L} \mathrm{RN}$ was reacted with $1.35 \mathrm{~g} / \mathrm{L}$ calcite in batch experiments. The residual RN in solution was measured at 24 hours and 30 days. Samples were analyzed by ICP-MS. For Np, $\sim 1 * 10^{-7} \mathrm{~mol} / \mathrm{L} \mathrm{Np}(\mathrm{V})$ was reacted with $1.34 \mathrm{~g} / \mathrm{L}$ calcite in batch experiments. The $\mathrm{Np}(\mathrm{V})$ remaining in solution after 24 hours was measured by scintillation counting. High speed centrifugation was used instead of filtration to eliminate the potential for RN loss during filtration. Sorption modeling was 
accomplished using the 24 hour measurements. Blanks were run in parallel in all experiments. Only minor loss of RN to container walls was observed.

Figures 9 and 10 present the aqueous speciation of $\mathrm{Sm}(\mathrm{III})$ and $\mathrm{Eu}(\mathrm{III})$ under the conditions of the calcite sorption experiments. For both RNs, the positively charged monocarbonate species dominates below $\mathrm{pH} 8.4$ and the negatively charged dicarbonate species dominates at $\mathrm{pH}>8.4$. The presence of negatively charged carbonate species suggests that sorption will likely be suppressed at high $\mathrm{pH}$ under these condition.

Figures 11 and 12 present the $\mathrm{Np}(\mathrm{V})$ speciation under the condition of the calcite sorption experiments. In Figure 9, the $\mathrm{NpO}_{2}\left(\mathrm{CO}_{3}\right)_{3}{ }^{5-}$ species is included while in Figure 10 , it is excluded. The stability of the tri-carbonate neptunium species under relatively mild alkaline conditions needs to be examined further. Nevertheless, the speciation pattern observed with or without the presence of this species is similar: below $\mathrm{pH} 8.5$, the $\mathrm{NpO}_{2}{ }^{+}$species dominates while at high $\mathrm{pHs}$, the negatively charged carbonate species dominate. As in the case of $\mathrm{Sm}(\mathrm{III})$ and $\mathrm{Eu}(\mathrm{III})$, the results suggest that $\mathrm{Np}(\mathrm{V})$ sorption will be suppressed at high $\mathrm{pH}$.

Several assumptions were made in determining $\mathrm{RN}$ sorption constants on calcite. The site density used in modeling sorption was determined from calculating the Ca positions along the 104 plane of calcite $\left(8.31 * 10^{-6} \mathrm{~mol} / \mathrm{m}^{2}\right)$. Also, only a single site type was assumed to react with RNs on the calcite surface.

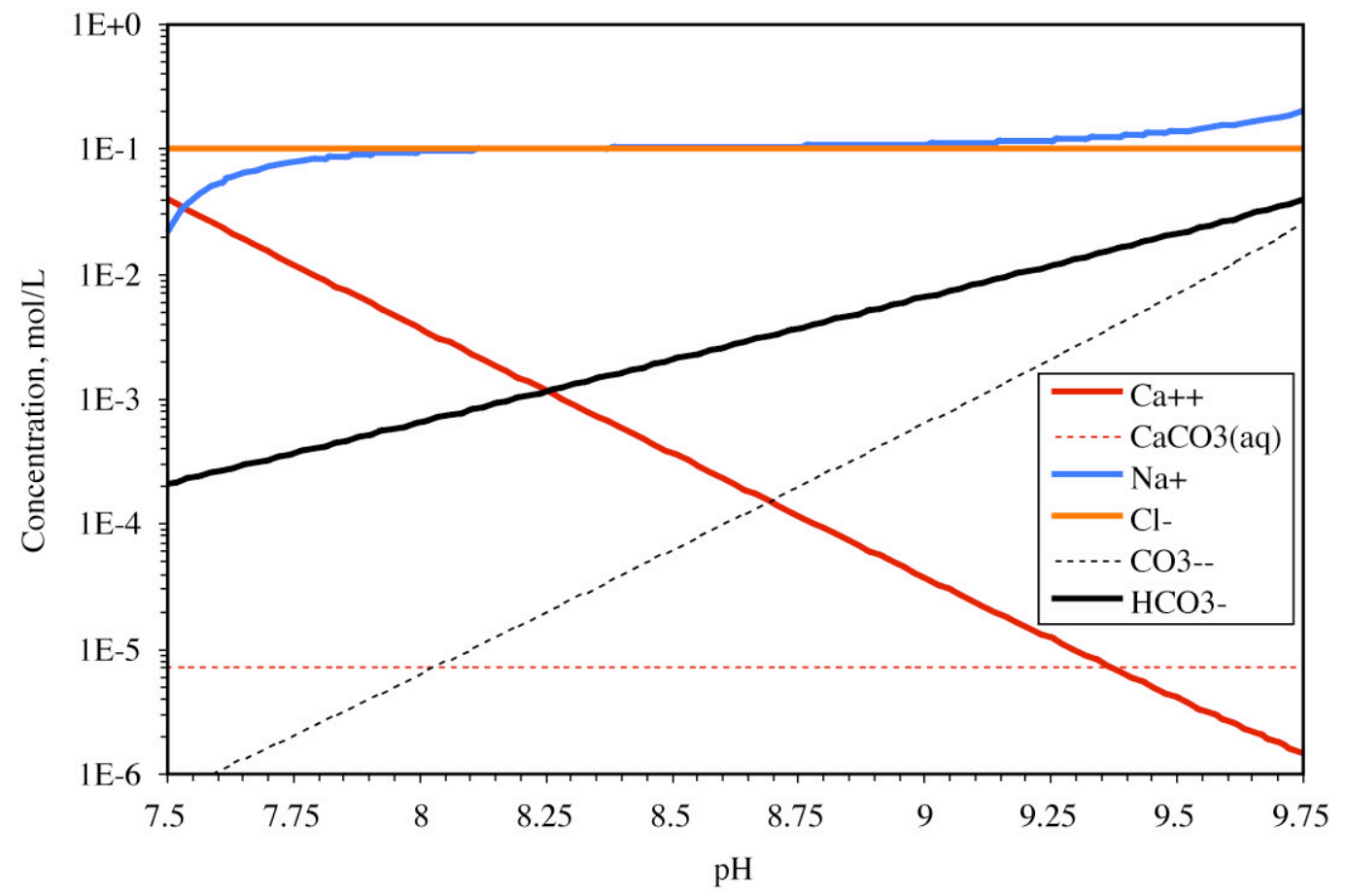

Figure 7. Major ion composition of waters used in calcite batch sorption experiments. 


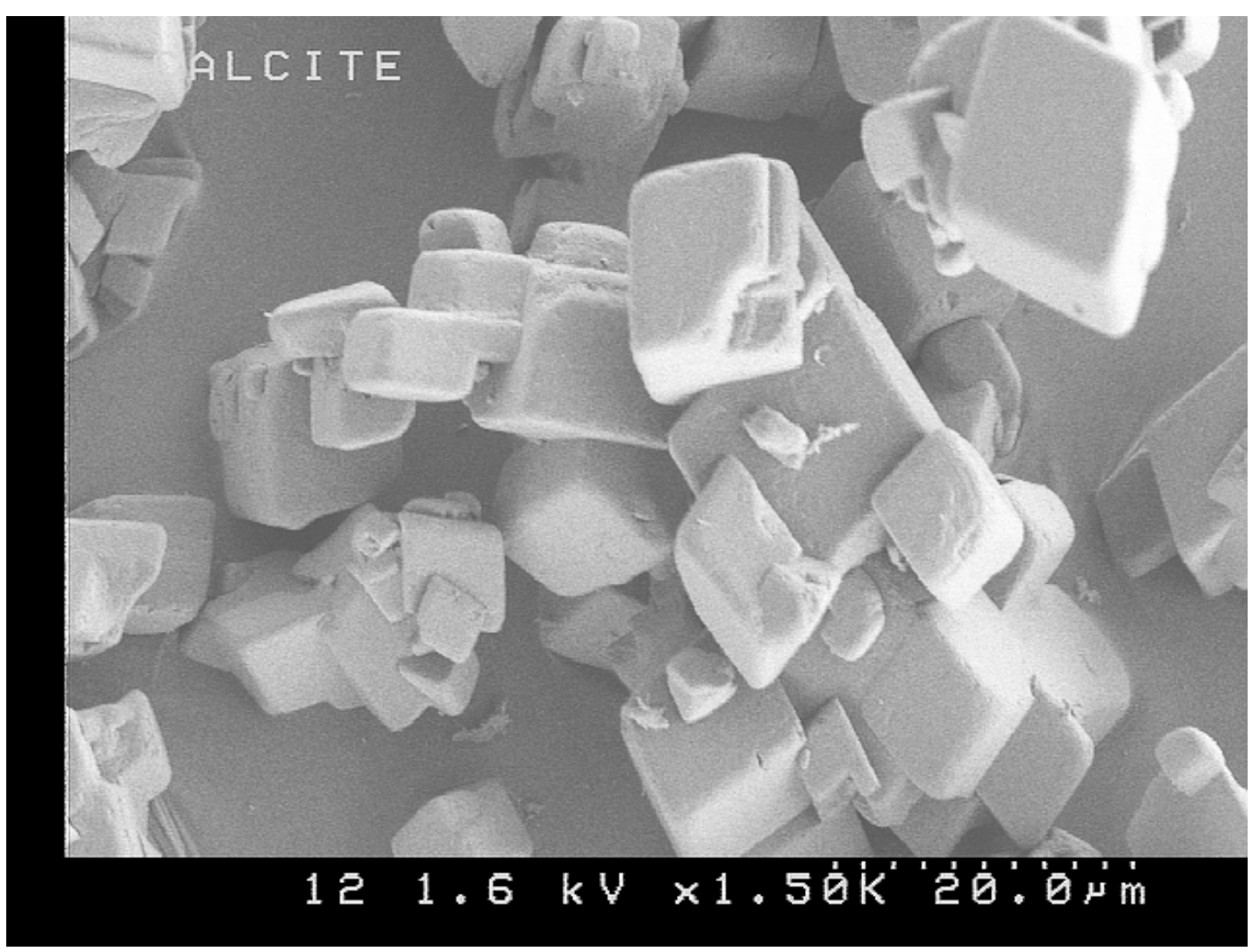

Figure 8. Calcite SEM photo.

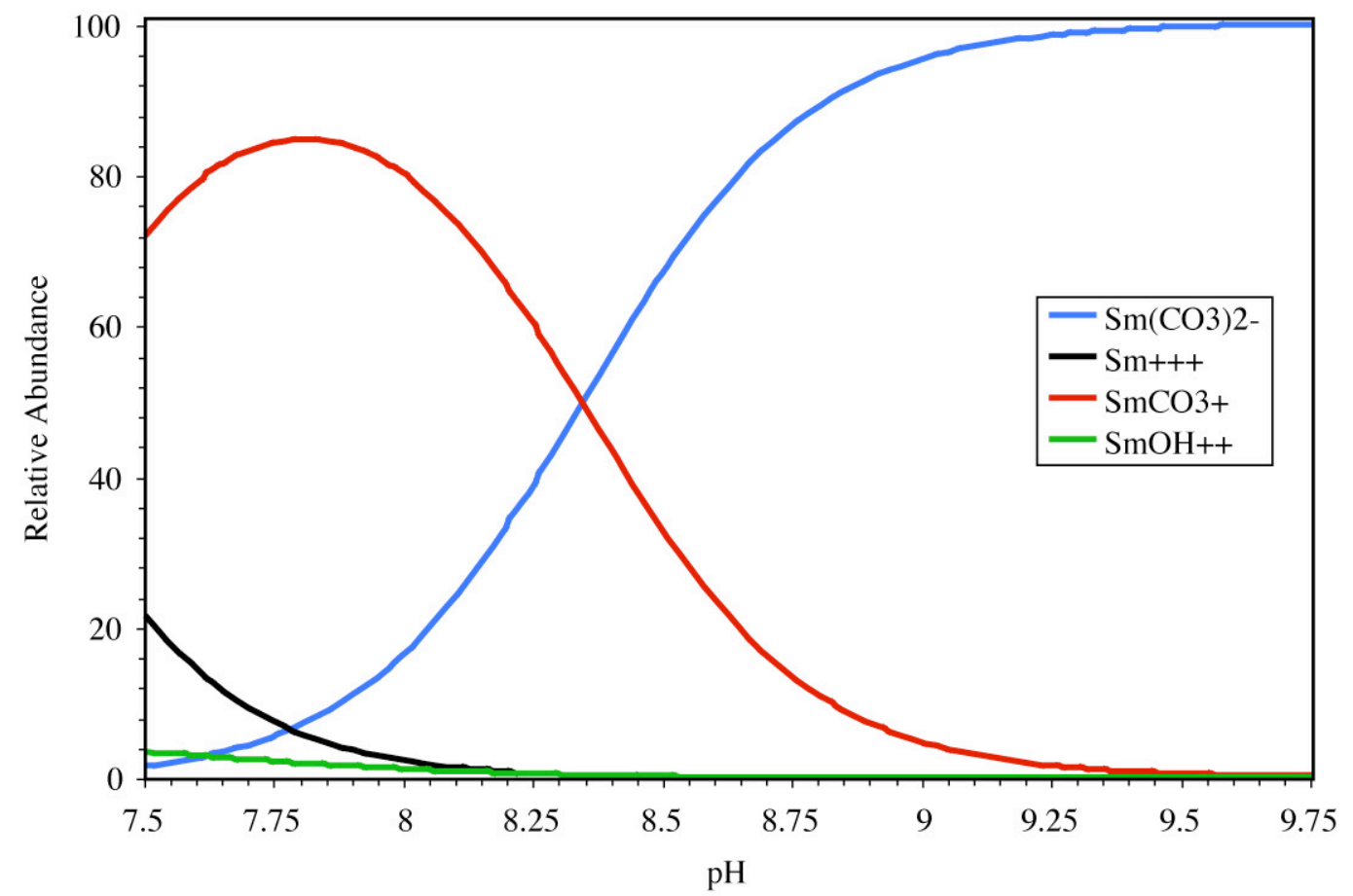

Figure 9. Speciation of Sm(III) under conditions of calcite sorption experiments. 


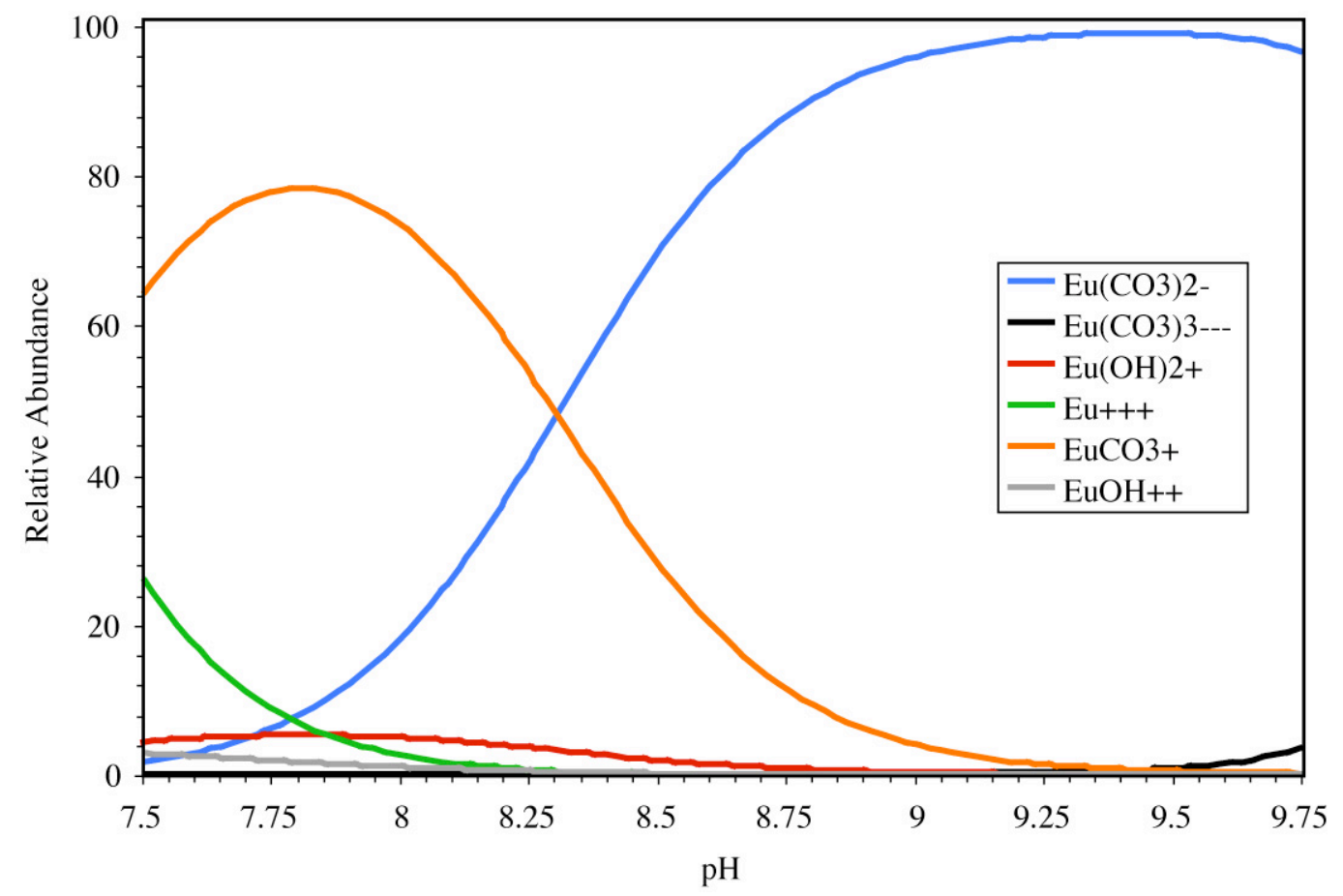

Figure 10. Speciation of $\mathrm{Eu}(\mathrm{III})$ under conditions of calcite sorption experiments.

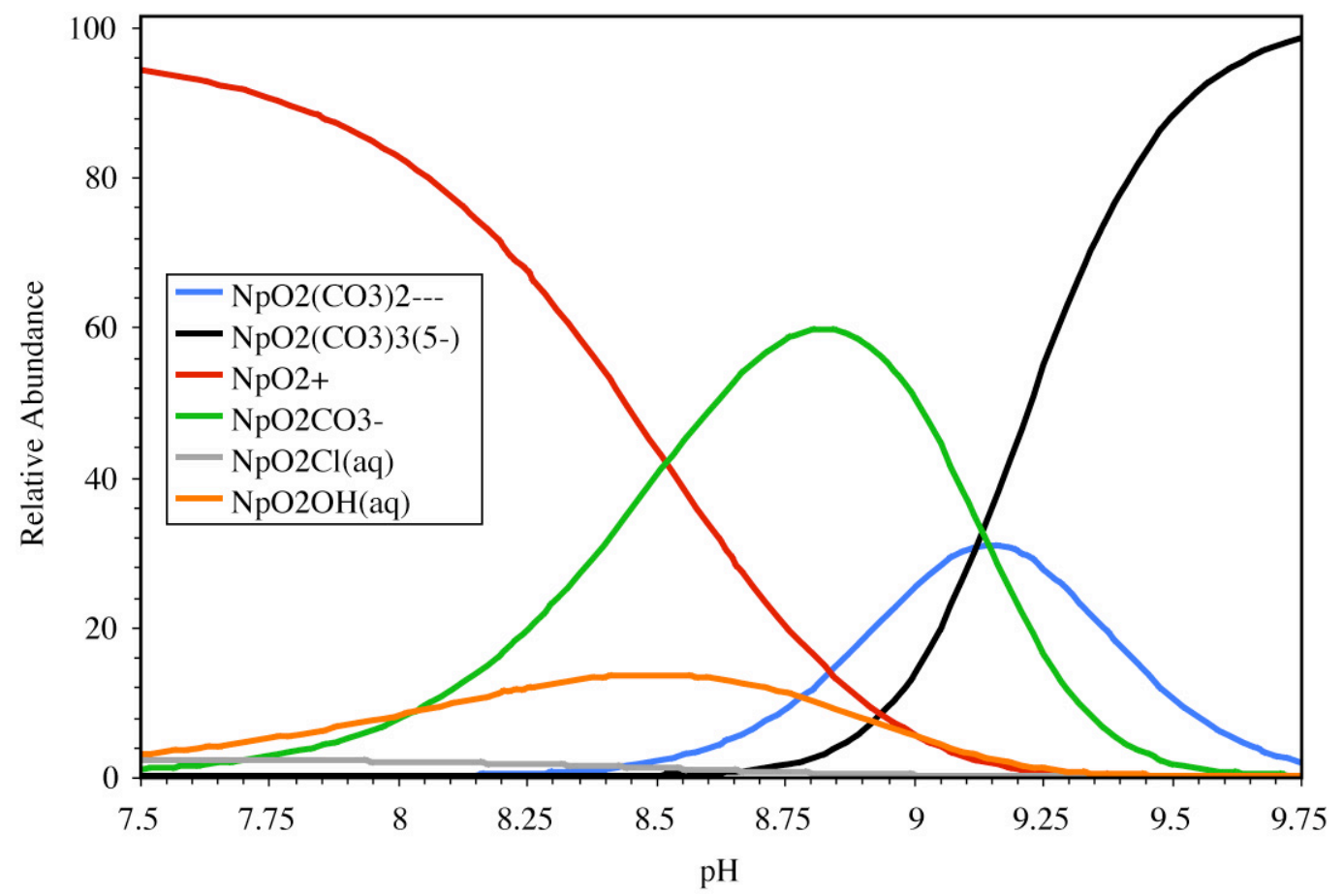

Figure 11. Speciation of $\mathrm{Np}(\mathrm{V})$ under condition of calcite sorption experiments (NpO2(CO3)35- species included. 


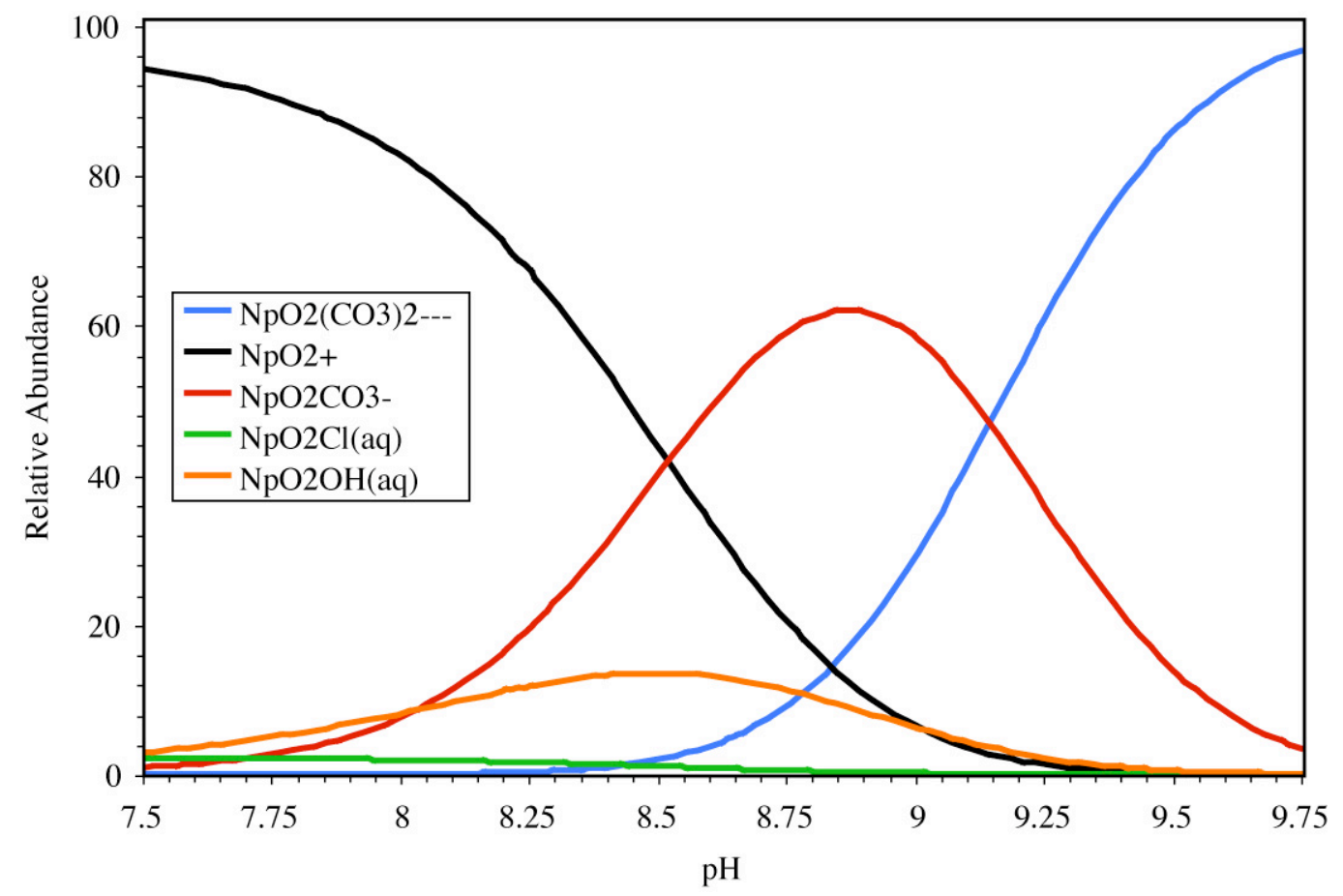

Figure 12. Speciation of $\mathrm{Np}(\mathrm{V})$ under conditions of calcite sorption experiment (NpO2(CO3)35- species excluded).

Unlike the heulandite SC reactions, calcite reactions were written as surface exchange reactions. ${ }^{12}$ This is, in part, due to inadequate study of sorption on slightly soluble minerals such as calcite (as compared to the many numbers of iron oxide sorption studies, for example). Most calcite sorption modeling studies have assumed that cations sorb by exchange with Ca (Zachara et al., 1991; Doner and Zavarin, 1997) and we use the same approach here. For example, the exchange between $\mathrm{Ca}$ and $\mathrm{Pu}^{4+}$ at the calcite surface is written in the following form:

$>\mathrm{CO}_{3} \mathrm{Ca}^{2+}+\mathrm{Pu}^{4+} \Leftrightarrow>\mathrm{CO}_{3} \mathrm{Pu}^{4+}+\mathrm{Ca}^{2+}$

$\mathrm{K}=\frac{\left(>\mathrm{CO}_{3} \mathrm{Pu}^{4+}\right)\left(\mathrm{Ca}^{2+}\right)}{\left(>\mathrm{CO}_{3} \mathrm{Ca}^{2+}\right)\left(\mathrm{Pu}^{4+}\right)}$

where the concentration of $>\mathrm{CO}_{3} \mathrm{Ca}^{2+}$ is equal to the concentration of $\mathrm{Ca}$ sites on the surface. The above equation is equivalent, in form, to surface complexation. It is unusual only in that the sorbing ion is competing with $\mathrm{Ca}^{2+}$ for the surface sites. In addition, if one required that the calcite surface retain electroneutrality, the above reaction would better be described using the ion exchange conventions. Below, we attempt to use both ion exchange and non-electrostatic surface complexation conventions

\footnotetext{
${ }^{12}$ A surface complexation model of the carbonate mineral-solution interface has been proposed (Van Cappellen et al., 1993) but has not been widely used to model sorption.
} 
to model RN sorption to calcite and assess how well those models can fit our sorption data.

\section{Results and Discussion}

Table 3 contains the best fit $\log K$ values for the various surface complexation and ion exchange models used to fit the sorption data. The following sections discuss the individual fits to the data.

\subsection{Eu Sorption to Heulandite}

Figure 13 is a log scale plot of aqueous Eu(III) in solution as a function of $\mathrm{pH}$ in equilibrium with the heulandite at high ionic strength. The dashed line at the top of the figure indicates the initial $\mathrm{Eu}(\mathrm{III})$ concentration in solution prior to sorption. Sorption data is more typically presented as \% sorbed as a function of $\mathrm{pH}$. Here, we present the aqueous concentration data and on a log scale to better resolve the strong partitioning of Eu. Several important points can be made with regards to the sorption data itself. First, sorption at high $\mathrm{pH}$ between 24 hours and 30 days increases dramatically which may be the result of slow sorption kinetics, secondary precipitate formation, or possibly slow ion exchange mechanisms. Second, in certain cases, $\mathrm{pH}$ drift over the experimental time period is large (30 day $\mathrm{pH} 9.5$ sample, for example). Third, the decrease in sorption at high $\mathrm{pH}$ for the 24 hour sorption experiments is consistent with the aqueous speciation data (which indicates that negatively charged Eu-carbonate species dominate at high $\mathrm{pH}$ ).

Table 3. Best fit parameters for modeling sorption to heulandite and calcite.

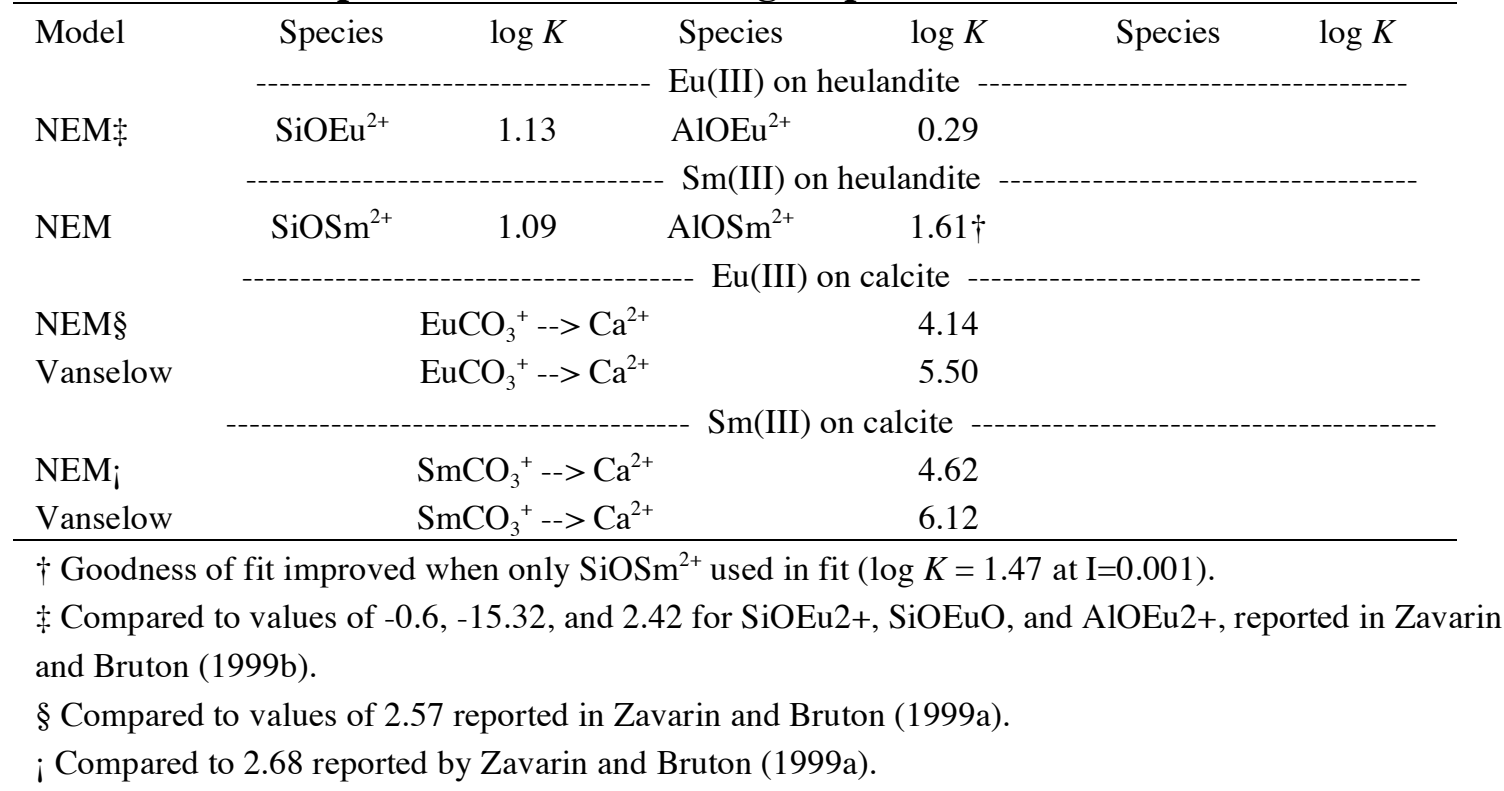




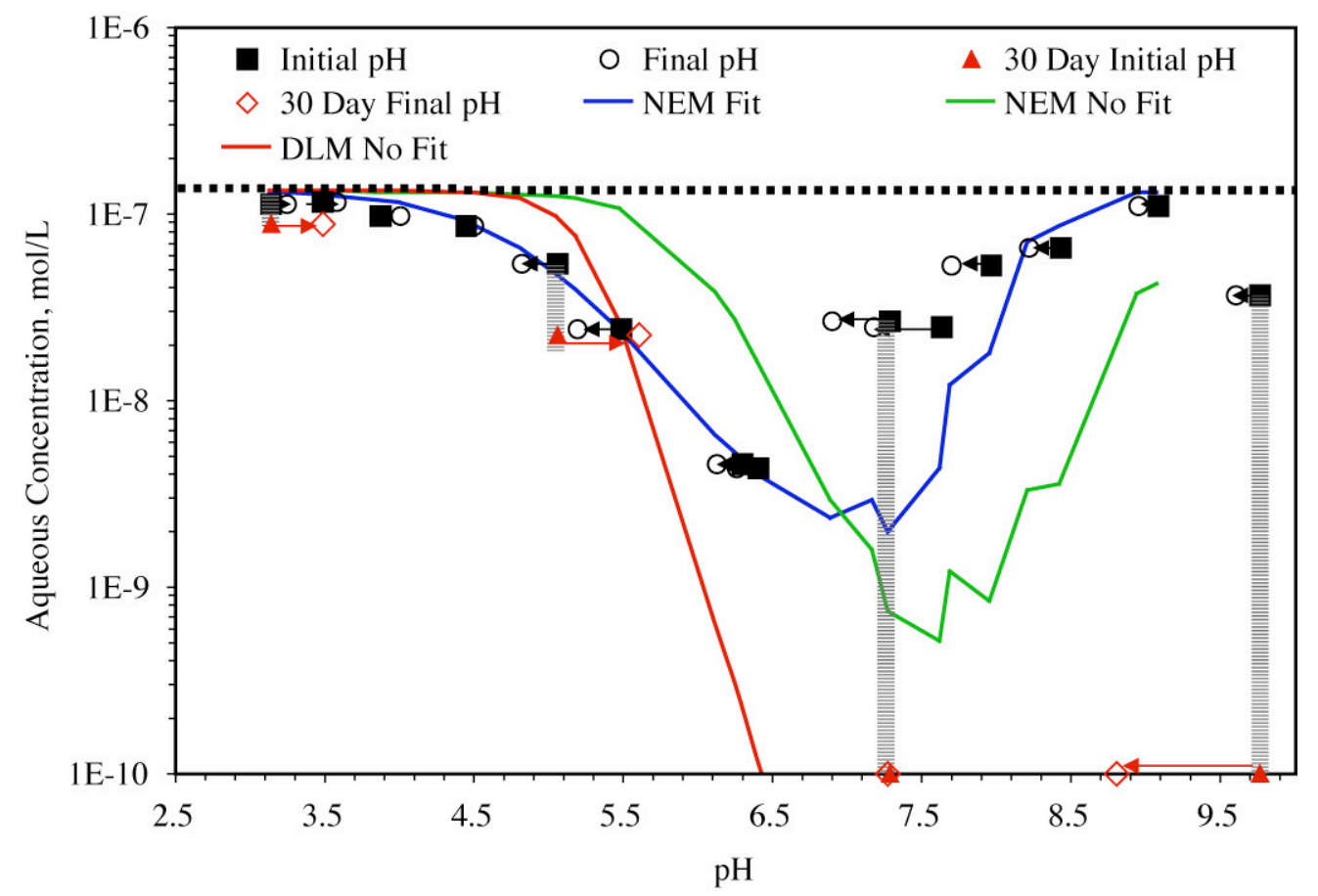

Figure 13. Sorption data for $\mathrm{Eu}$ (III) on heulandite at $\mathrm{I}=0.1$ and several $\mathrm{SC}$ model fits. Dashed line represents the initial aqueous concentration in solution. Vertical grey lines link the associated 24 hour and 30 day samples. Initial and final pH data illustrate the level of $\mathrm{pH}$ drift during experiments

Three model fits are presented. The NEM fit using SC constants derived from published silica and alumina sorption data (Zavarin and Bruton, 1999b) is in approximate agreement with the sorption data. Published Eu sorption data was limited and the SC constants in Zavarin and Bruton (1999b) were estimated largely from sorption data in which mineral surface area and solution composition were not known. It is, therefore, not unexpected that the fit is poor. By adjusting the SC constants, the 24 hours sorption data could be fit well. The new reaction constant for Eu interaction with silanol sites will result in significantly greater $\mathrm{RN}$ sorption in our reactive transport models (i.e. significantly reduced Eu migration from the near field). However, the data fits suggest that sorption to aluminol sites is minimal. This is unexpected since aluminol reactive sites are typically thought to sorb cations more strongly than silanol sites. Two factors may be affecting these results: 1) our estimate of aluminol reactive sites on the surface is flawed and/or 2) reactivity of aluminol sites on heulandite is much weaker than expected from aluminum oxide sorption data. In our data fits, it was assumed that the $\mathrm{AlOH} / \mathrm{SiOH}$ surface site ratio was equivalent to the $\mathrm{Al} / \mathrm{Si}$ ratio in the solid. Ragnarsdottir et al. (1996) examined the composition of heulandite at the mineral-water interface using SIMS. They found that at nearly all $\mathrm{pH}$, a depletion of $\mathrm{Al}$ near the mineral surface occurred over time. This would suggest that the contribution of aluminol reactive sites to the sorptive capacity of heulandite may be small. This would be consistent with our sorption fits.

Attempts to fit sorption data using the DLM failed in all cases. This result is surprising given that the DLM is believed to be a more realistic representation of surface 
complexation. Again, our estimates of aluminol and silanol reactive sites and their respective acidity constants may significantly affect our ability to fit the data using the DLM.

Figure 14 presents the sorption data at low ionic strength. Although some sorption at low $\mathrm{pH}$ suggests that ion exchange may be contributing to sorption, the strong $\mathrm{pH}$ dependence to sorption suggests that surface complexation is the dominant mechanism controlling sorption. Fits to this data are consistent with the above discussion regarding sorption at high ionic strength.

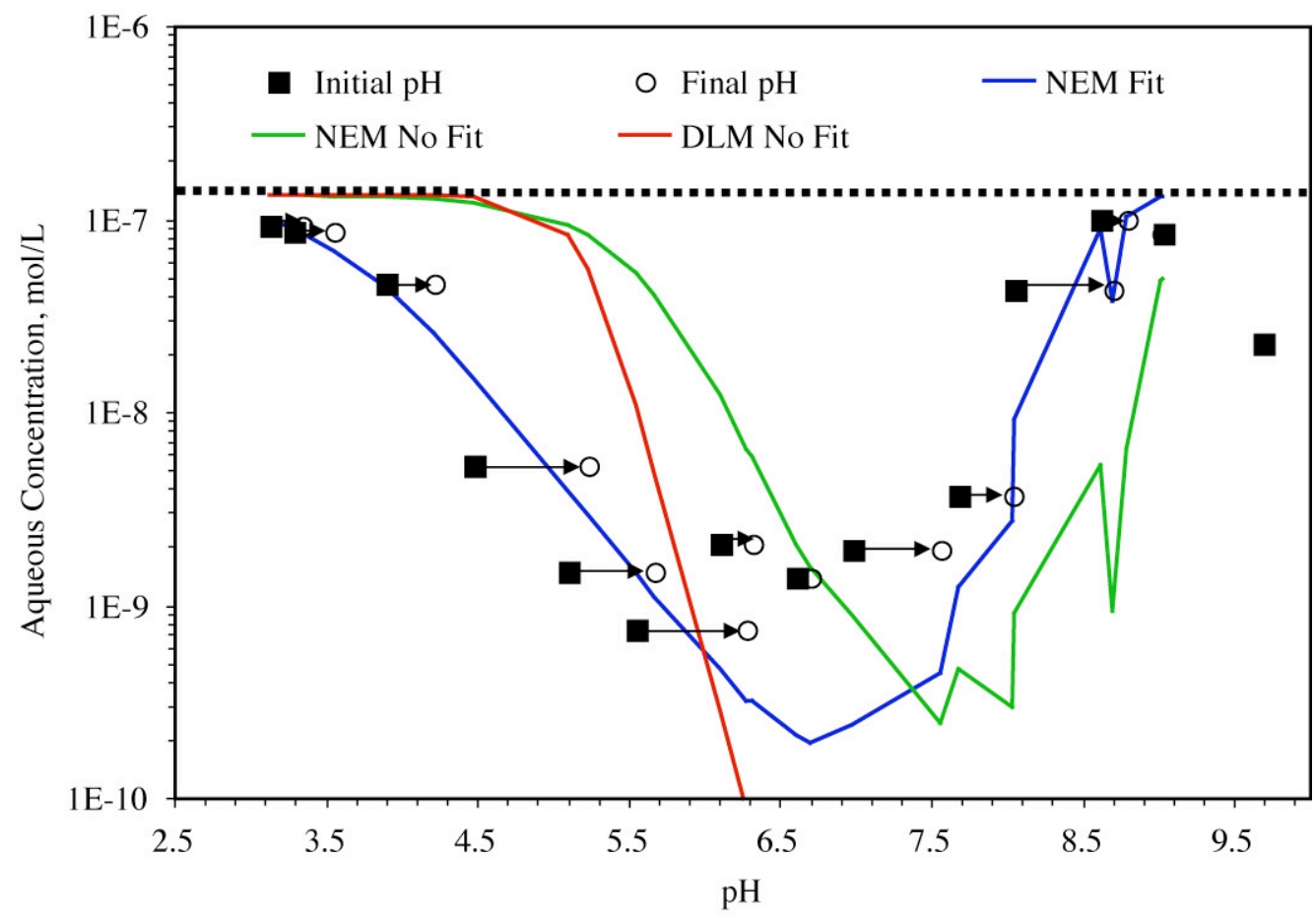

Figure 14. Sorption data for $\mathrm{Eu}(\mathrm{III})$ on heulandite at $\mathrm{I}=\mathbf{0 . 0 0 1}$ and several SC model fits. Dashed line represents the initial aqueous concentration in solution. Initial and final pH data illustrate the level of pH drift during experiments. 


\subsection{Sm Sorption to Heulandite}

Sorption data and fits for Sm on heulandite are shown in Figures 15 and 16. The results are nearly identical to that of Eu on heulandite, as would be expected. The NEM fits suggest that the sorption of Sm to silanol groups is equivalent to that of Eu (Table 3). The reaction constants for Sm sorption to aluminol sites is significantly different than the reaction constant for $\mathrm{Eu}$. This may largely be a function of the scatter in the sorption data since the fit to these data using exclusively silanol reactive sites is as good or better than with the addition of aluminol reactive sites. Again, this seems to indicate that the heulandite surface is depleted in $\mathrm{Al}$ and that sorption is largely controled by $\mathrm{RN}$ reaction to $\mathrm{SiOH}$ reactive sites. These results also suggest that the sorptive behavior of Sm and $\mathrm{Eu}$ is equivalent. The addition of $\mathrm{Sm}$-aluminosilicate sorption to our reactive transport model will significantly decrease our prediction of Sm migration in areas where colloid mediated transport is not significant.

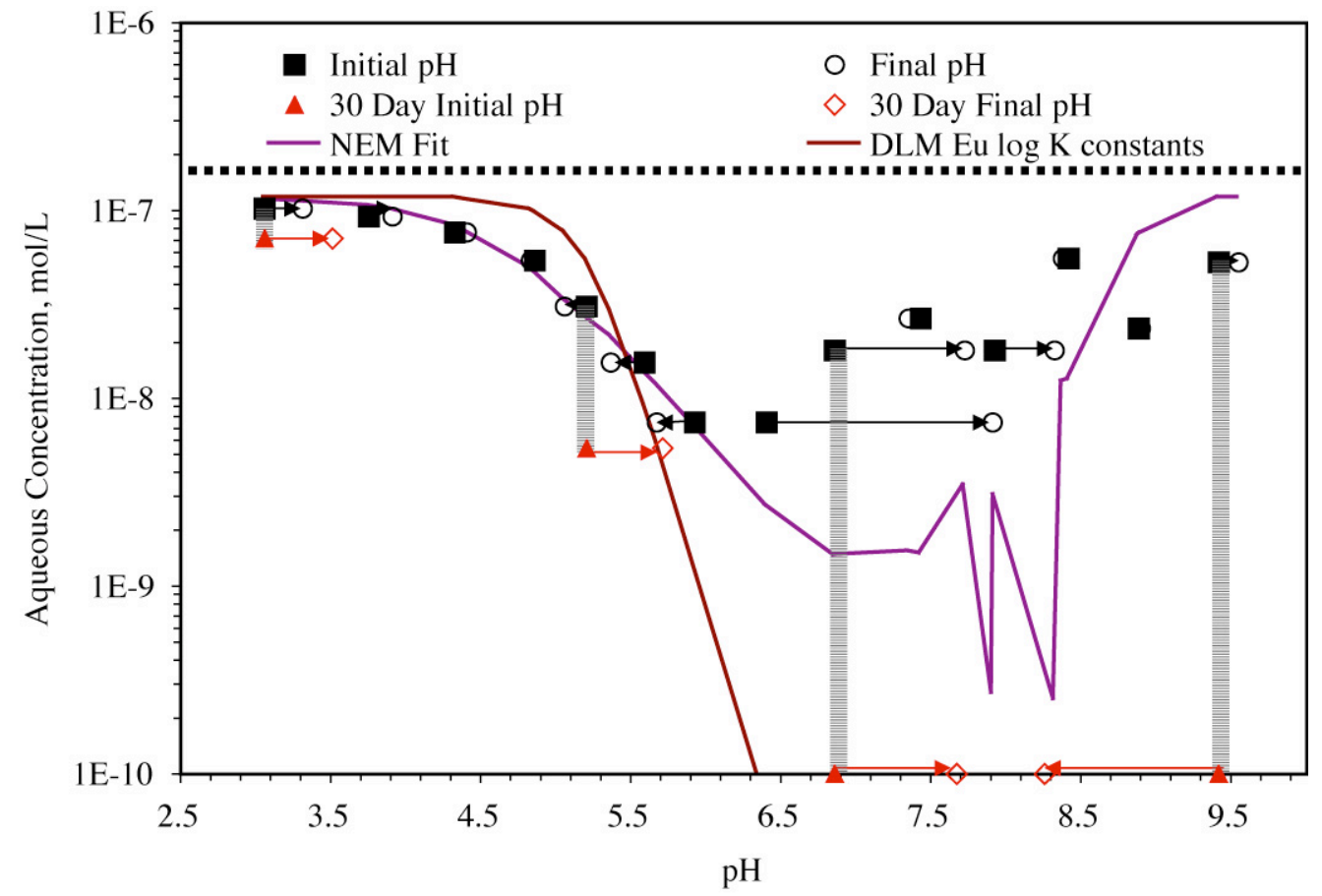

Figure 15. Sorption data for $\mathbf{S m}$ (III) on heulandite at $\mathrm{I}=\mathbf{0 . 1}$ and several $\mathrm{SC}$ model fits. Dashed line represents the initial aqueous concentration in solution. Vertical grey lines link the associated 24 hour and 30 day samples. Initial and final pH data illustrate the level of $\mathrm{pH}$ drift during experiments. 


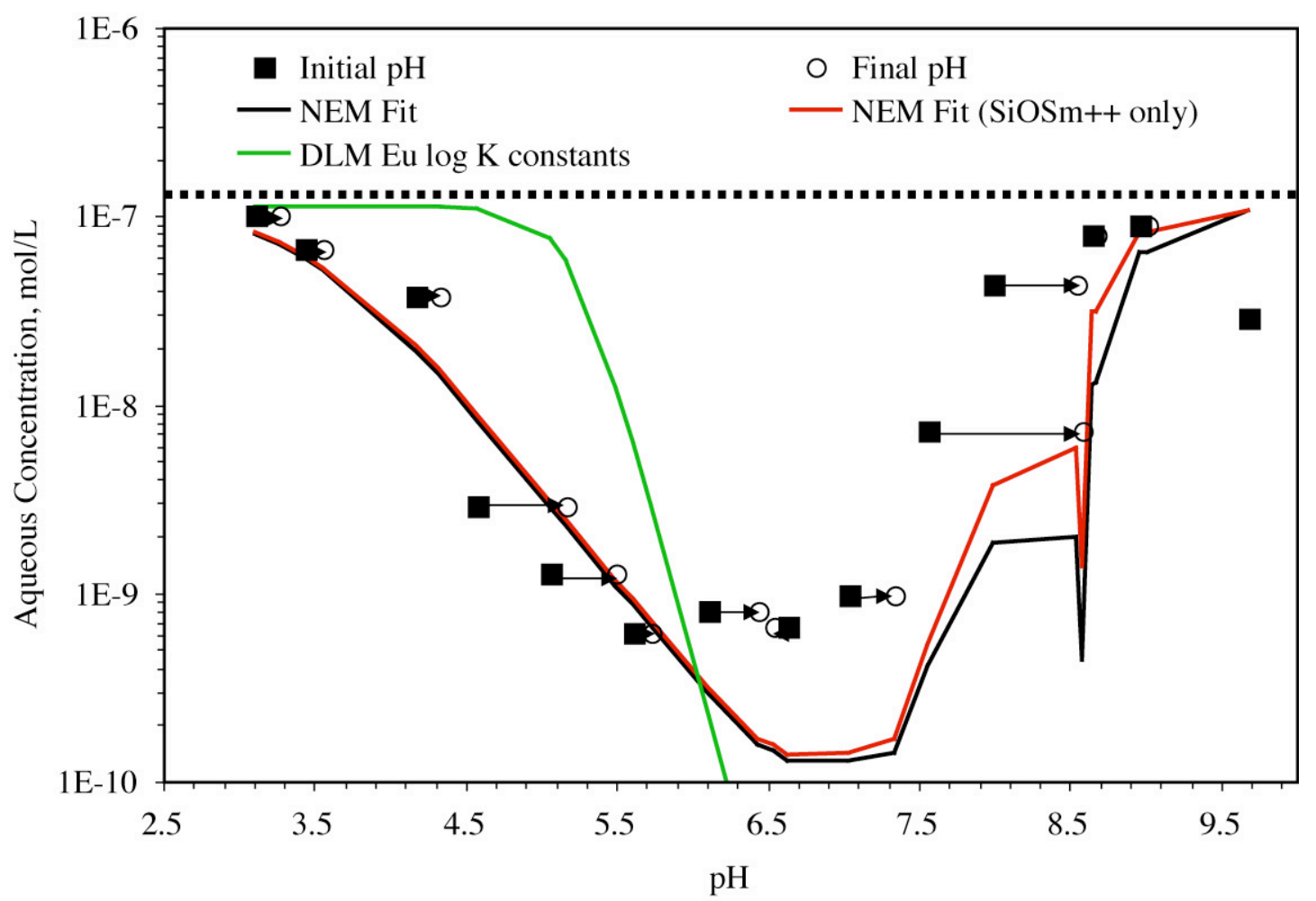

Figure 16. Sorption data for $\mathrm{Sm}$ (III) on heulandite at $\mathrm{I}=\mathbf{0 . 0 0 1}$ and several $\mathrm{SC}$ model fits. Dashed line represents the initial aqueous concentration in solution. Initial and final $\mathrm{pH}$ data illustrate the level of $\mathrm{pH}$ drift during experiments.

\subsection{Np Sorption to Heulandite}

$\mathrm{Np}(\mathrm{V})$ sorption to heulandite was significantly weaker than that of $\mathrm{Sm}(\mathrm{III})$ or $\mathrm{Eu}(\mathrm{III})$ (Figure 17). This is consistent with our observation of $\mathrm{Pu}(\mathrm{V})$ sorption to clinoptilolite. Some evidence that $\mathrm{Np}(\mathrm{V})$ may diffuse into the zeolite channels is evident at low $\mathrm{pH}(\mathrm{pH} 3.5$ - 5.5). These samples will be monitored for longer time periods to examine whether slow diffusion into the zeolite channels is, indeed, taking place. The increased sorption at $\mathrm{pH}>8.5$ is consistent with the expected deprotonation of aluminol sites at that $\mathrm{pH}$. Nevertheless, sorption is simultaneously being suppressed by aqueous $\mathrm{Np}$-carbonate complexation at high $\mathrm{pH}$. 


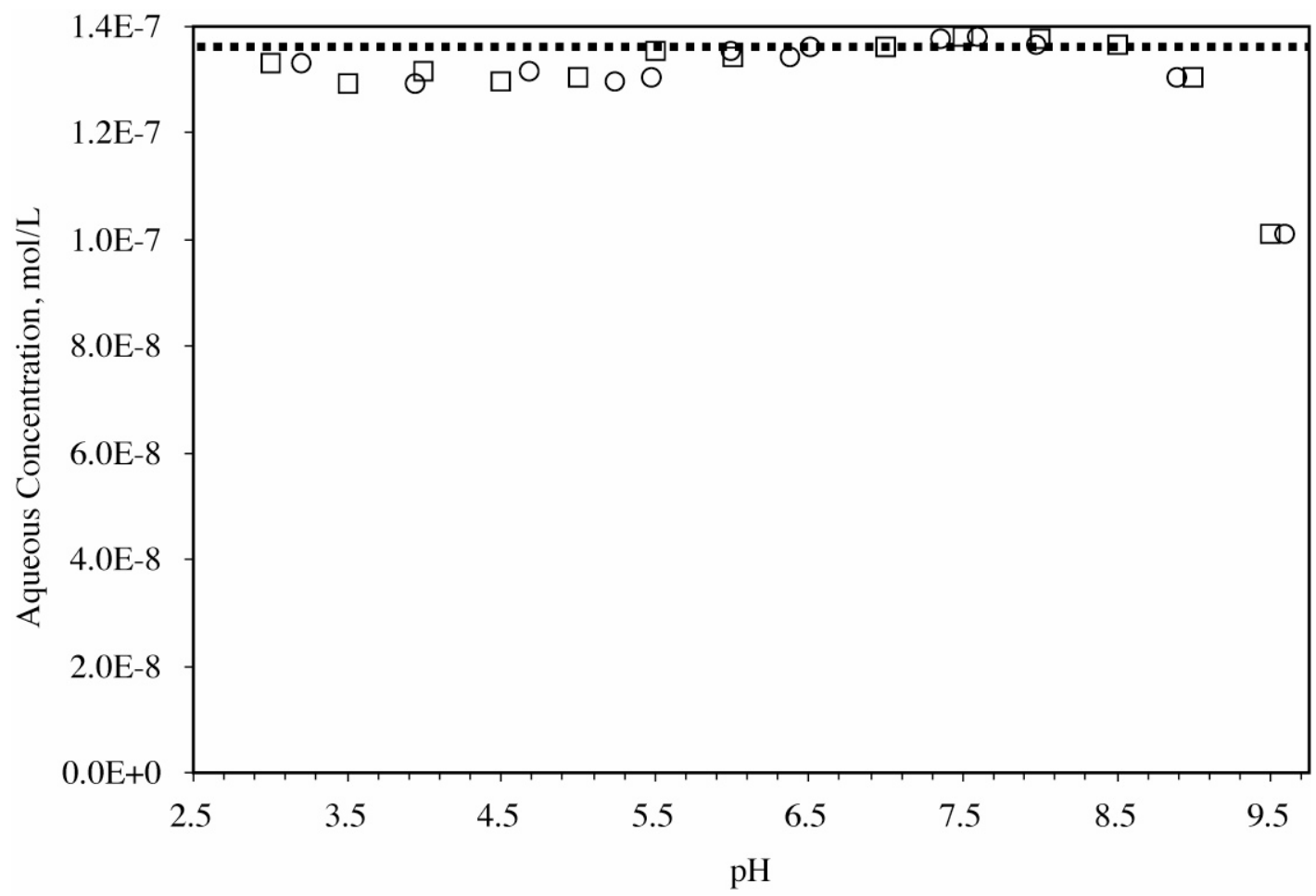

Figure 17. Sorption data for $\mathrm{Np}(\mathrm{V})$ on heulandite at $\mathrm{I}=\mathbf{0 . 1}$. Dashed line represents the initial aqueous concentration in solution. Initial and final $\mathrm{pH}$ data illustrate the level of pH drift during experiments. Open squares are ideal pH; open circles are final pH measurements.

\subsection{Eu Sorption to Calcite}

Figures 18 and 19 present the Vanselow IE, Gapon IE, and NEM SC fits to $\mathrm{Eu}$ (III) sorption to calcite. Unlike the heulandite case, $\mathrm{pH}$ drift in these experiments was minimal owing largely to the buffering capacity of the calcite saturated solutions. The increased sorption with time is most likely the result of calcite recrystallization which effectively increases the net reactive surface area of calcite in these experiments. Sorption across the $\mathrm{pH}$ range examined varies by less that one order of magnitude. Nevertheless, at low $\mathrm{pH}$ and at high $\mathrm{pH}$ sorption is reduced. At low $\mathrm{pH}$, the reduced sorption is most likely a result of the increased $\mathrm{Ca}^{2+}$ concentration in solution which effectively competes for reactive sites. At high $\mathrm{pH}$, it is a result of negatively charged Eu-dicarbonate species formation. For the NEM case, only two species could effectively model the sorption data: $\mathrm{EuCO}_{3}{ }^{+}$and $\mathrm{Eu}(\mathrm{OH})_{2}{ }^{+}$. The $\mathrm{EuCO}_{3}{ }^{+}$species was used to model Eu sorption to calcite in our previous reactive transport simulations (see Figure 15 and Table 3 ). The $\log K$ constant conservatively estimated from a single sorption data point was 2.57 while the fit to our new data results in a value of 4.14 . In our models, this will result in a 1.5 order of magnitude decrease in Eu migration in areas where calcite is the dominant sorber. 


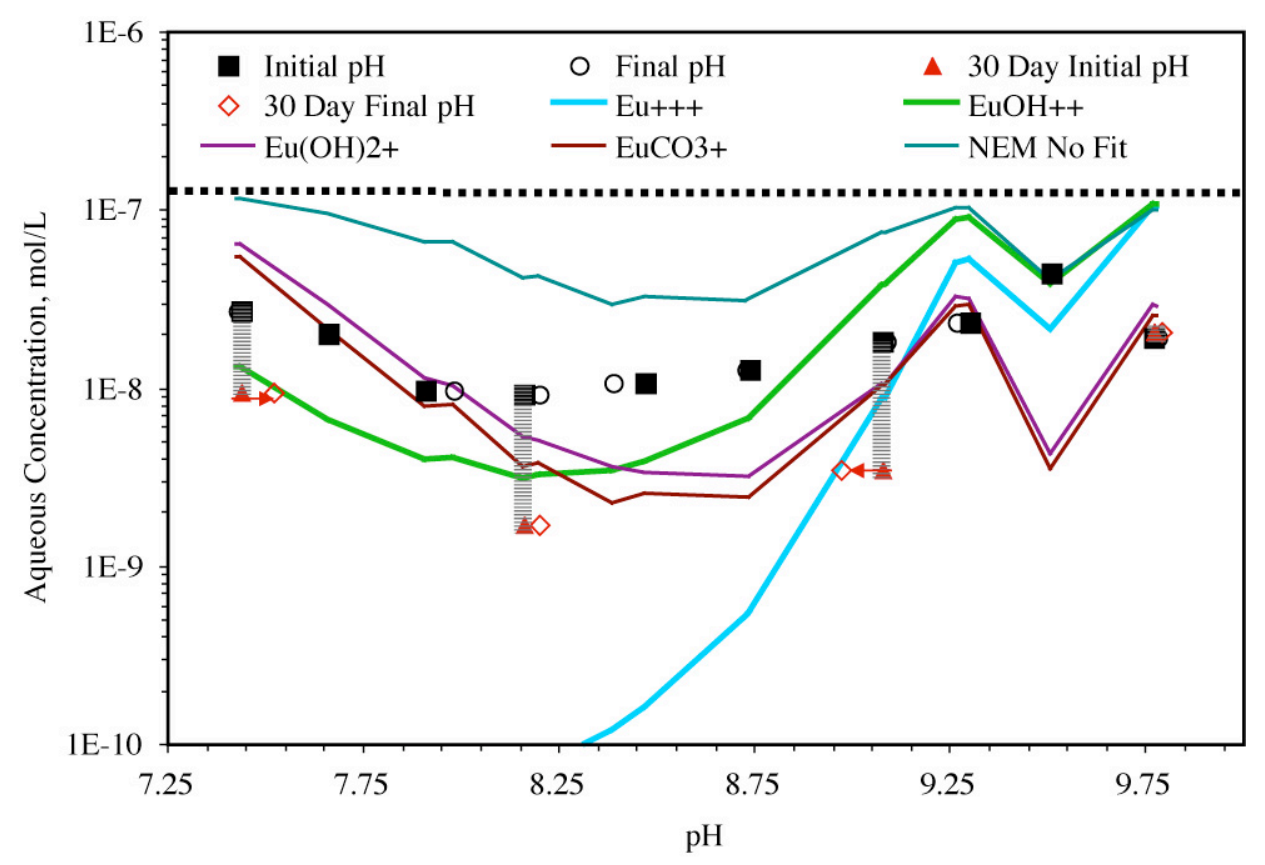

Figure 18. Eu sorption to calcite and NEM model fits using various aqueous species as exchangers. Dashed line represents the initial aqueous concentration in solution. Vertical grey lines link the associated 24 hour and 30 day samples. Initial and final pH data illustrate the level of $\mathbf{p H}$ drift during experiments

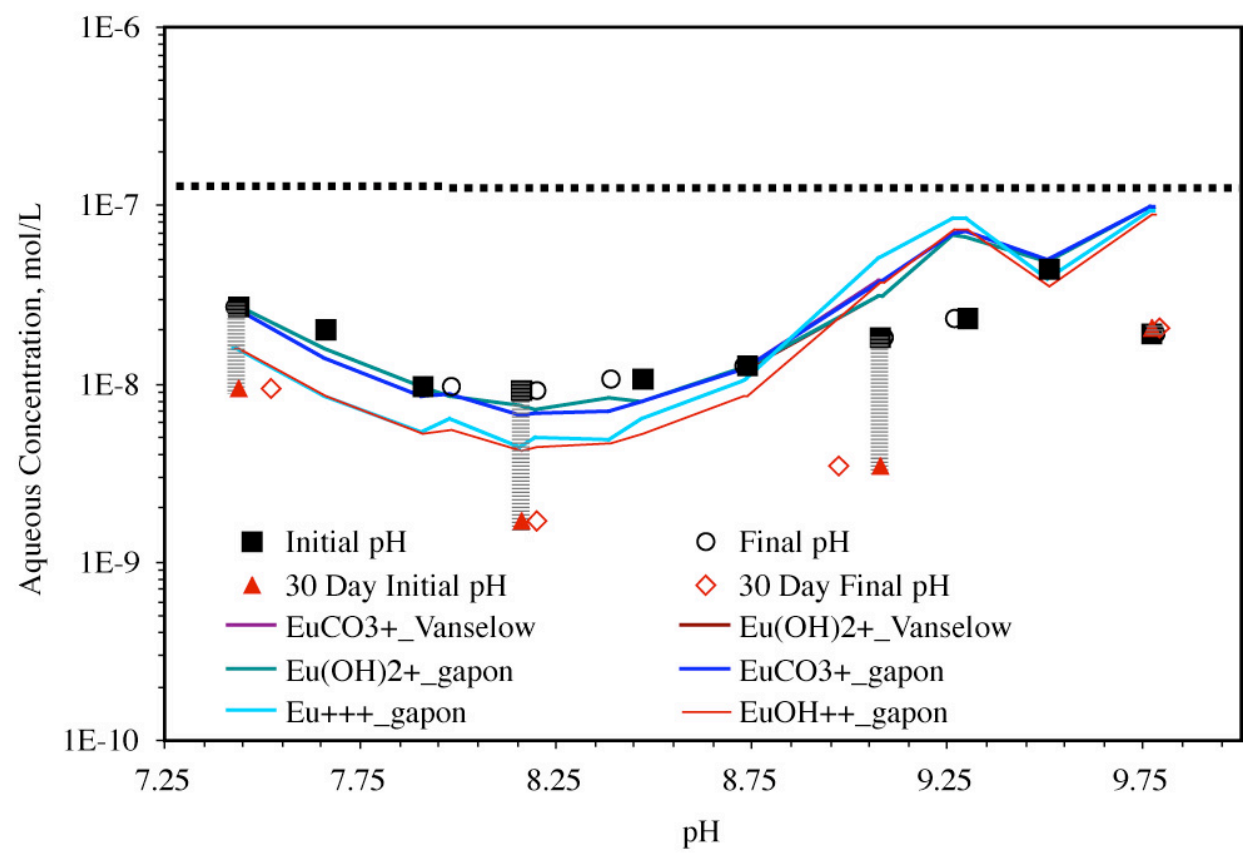

Figure 19. Eu sorption to calcite and ion exchange model fits using various aqueous species as exchangers. Dashed line represents the initial aqueous concentration in solution. Vertical grey lines link the associated 24 hour and 30 day samples. Initial and final $\mathrm{pH}$ data illustrate the level of $\mathrm{pH}$ drift during experiments 
Model fits to the Eu sorption data using the ion exchange models are very good (Figure 19). This would seem to indicate that Eu sorption to calcite may better be described using an ion exchange mechanism instead of the non-electrostatic surface complexation approach. However, recent data regarding sorption of Pu to calcite reveals that the ion exchange approach will not work for some radionuclides. Given this fact and published information suggesting that the calcite surface is variably charged, describing Eu sorption to calcite using surface complexation is more appropriate. The addition of electrostatics to the SC model might improve the fit to the data but this was not examined.

\subsection{Sm Sorption to Calcite}

Sm sorption to calcite is presented in Figures 20 and 21. The results are similar to those of Eu sorption, as would be expected. Again, the fitted $\mathrm{SmCO}_{3}{ }^{+}$non-electrostatic $\mathrm{SC} \log K$ is significantly higher than the previously used conservative value. This will result in greater retardation of Sm in our near field reactive transport models. These data also significantly reduce our uncertainty in the assigned reaction constants because previous estimates were based on a single data point available in the literature.

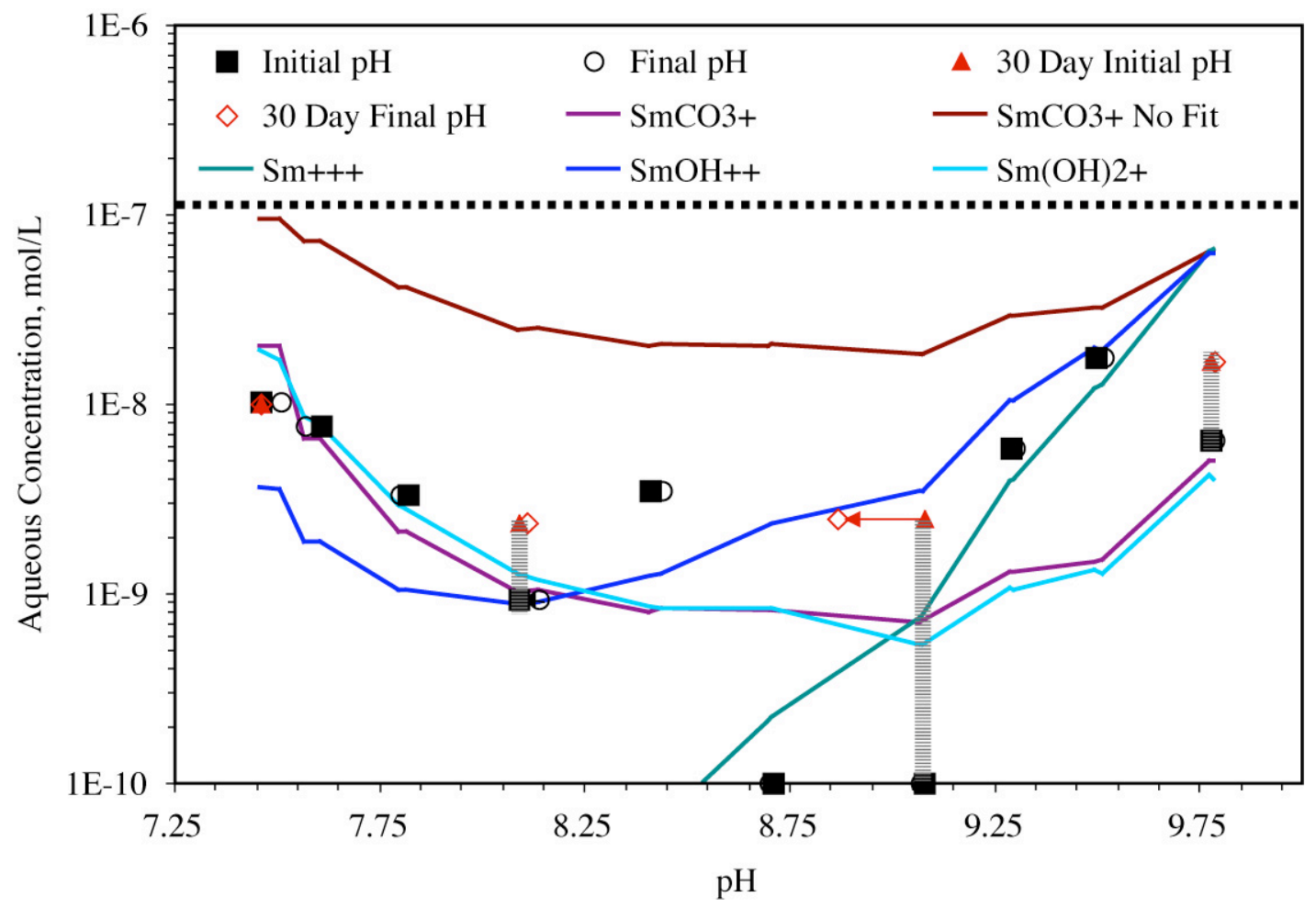

Figure 20. Sm sorption to calcite and NEM model fits using various aqueous species as exchangers. Dashed line represents the initial aqueous concentration in solution. Vertical grey lines link the associated 24 hour and 30 day samples. Initial and final pH data illustrate the level of $\mathrm{pH}$ drift during experiments. 


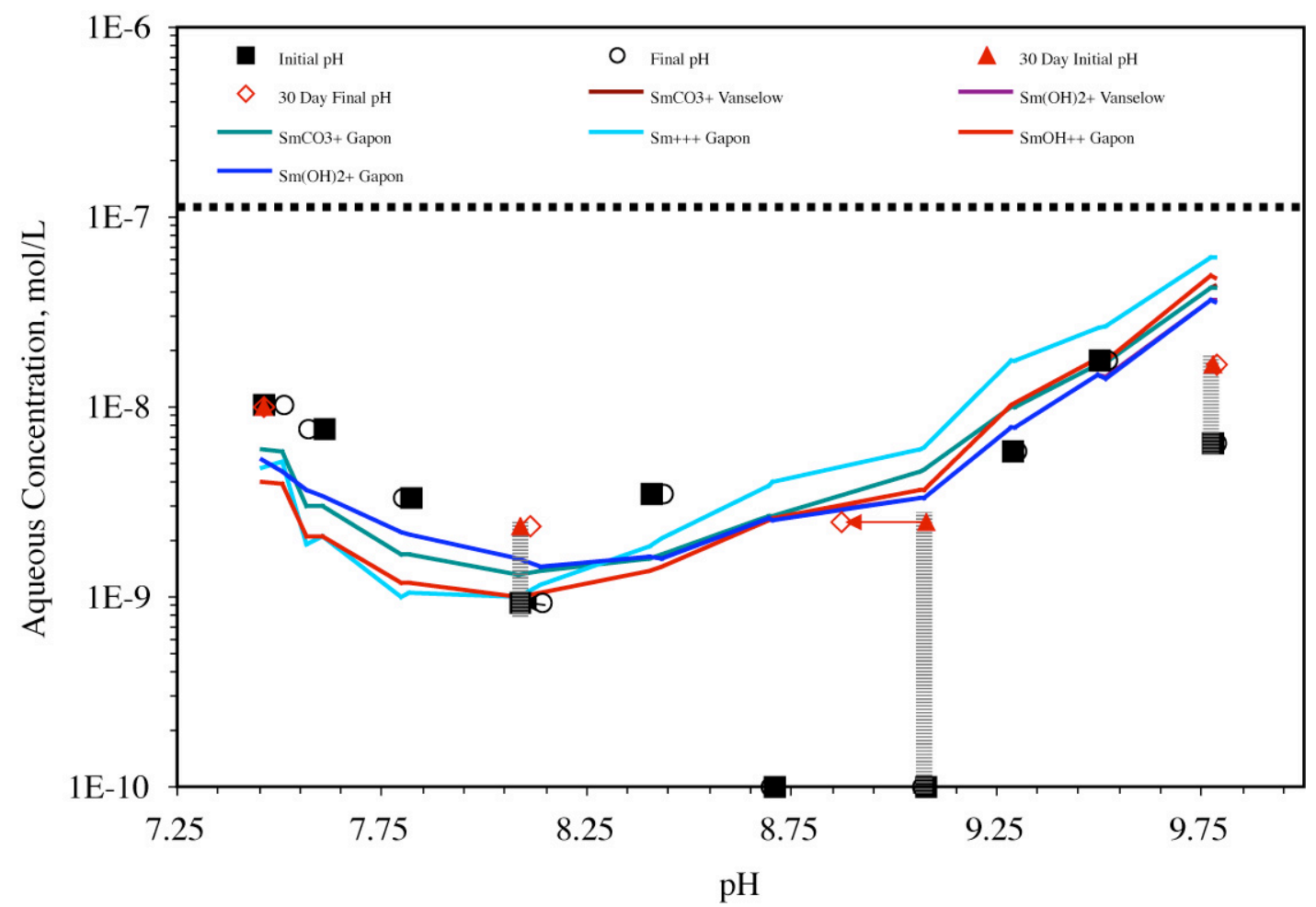

Figure 21. Sm sorption to calcite and ion exchange model fits using various aqueous species as exchangers. Dashed line represents the initial aqueous concentration in solution. Vertical grey lines link the associated 24 hour and 30 day samples. Initial and final $\mathrm{pH}$ data illustrate the level of $\mathrm{pH}$ drift during experiments

\subsection{Np Sorption to Calcite}

$\mathrm{Np}(\mathrm{V})$ sorption to calcite is, in general, consistent with the $\mathrm{Pu}(\mathrm{V})$ sorption data collected using identical solution and solid conditions. For $\mathrm{Np}(\mathrm{V})$, sorption is nearly unchanged across the entire $\mathrm{pH}$ range (except at the highest $\mathrm{pH}$ and carbonate concentration) (Figure 22). For the case of $\mathrm{Pu}(\mathrm{V})$, sorption did decrease to some degree at $\mathrm{pH}<8$ but not drastically. Our $\mathrm{Pu}(\mathrm{V})$ sorption data fitting experience would suggest that the best fit to $\mathrm{Np}(\mathrm{V})$ sorption data will be the non-electrostatic surface complexation of $\mathrm{NpO}_{2}^{+}$on the calcite surface. 


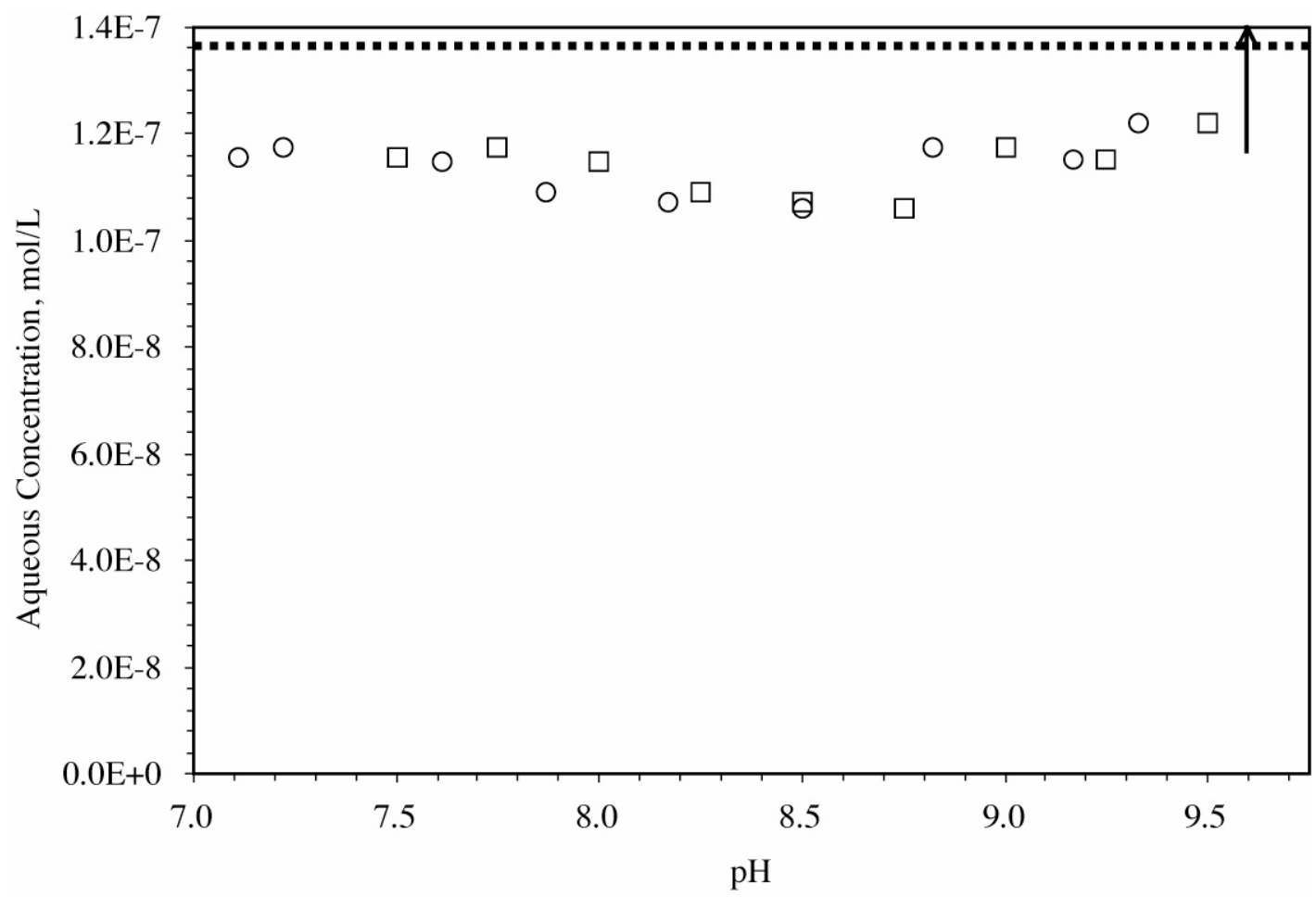

Figure 22. $N p(V)$ sorption to calcite. Dashed line represents the initial aqueous concentration in solution. Vertical arrow indicates that for one high $\mathrm{pH}$ sample, final Np concentration was somewhat greater than the initial concentration. Open squares are ideal $\mathrm{pH}$; open circles are final $\mathrm{pH}$ measurements.

\section{Conclusions}

Data regarding Eu sorption to heulandite revealed that previous estimates of $\mathrm{Eu}(\mathrm{III})$ sorption to silanol reactive sites were very conservative. The data collected and new reaction constants will significantly reduce our prediction of Eu migration in the near field when aluminosilicates are present. However, the data also suggest that aluminol reactive sites are either not present or their reactivity is significantly different from published Eu-aluminum oxide sorption data. In addition, our data suggest that a slow sorption process at high $\mathrm{pH}$ may retard Eu migration even further. The slower sorption process may be related to secondary precipitate formation or slow rates of RN diffusion into the inner channels of heulandite (however, the slow sorption does not occur at low $\mathrm{pH}$ which is inconsistent with ion exchange). Additional data regarding Eu and Sm diffusion into zeolite channels (ion exchange) was not available for inclusion in this report but will be incorporated into the Cheshire modeling effort of FY2001.

Data regarding Sm sorption to heulandite was consistent with Eu sorption, as would be expected. The difference in silanol $\log K$ surface complexation constants was only 0.04 . It is, therefore, reasonable to assume that the reactivity of Eu(III) and $\mathrm{Sm}$ (III) will be nearly equivalent and that Sm(III) interaction with aluminosilicates (and iron oxide) minerals could be extrapolated from Eu(III) data. 
$\mathrm{Eu}(\mathrm{III})$ and $\mathrm{Sm}(\mathrm{III})$ sorption to calcite was consistent with our previous estimates of RN surface complexation determined from published single point sorption data. The data presented here provides information on the $\mathrm{pH}$ dependence of $\mathrm{Eu}$ (III) and $\mathrm{Sm}$ (III) sorption to calcite and yields sorption constants that are significantly less conservative. The new sorption data yield a $\mathrm{Kd}$ value at $\mathrm{pH} 8$ that is approximately ten times greater than previously estimated. The resulting SC constants will, therefore, significantly reduce $\mathrm{Eu}$ and $\mathrm{Sm}$ mobility in our near field simulations.

Data and modeling of Sm and Eu sorption to both heulandite and calcite were presented in this report. $\mathrm{Np}(\mathrm{V})$ sorption experiments were performed but data have not been modeled at this time. Sorption data reveal that the $K d$ for $\mathrm{Np}(\mathrm{V})$ sorption to heulandite and calcite at $\mathrm{pH} 8$ and under the conditions of the above experiments is $\sim 0$ and $200 \mathrm{~mL} / \mathrm{g}$, respectively. An examination of data from the literature revealed that U(VI) sorption to zeolite surfaces will not be a significant sorption mechanism. However, the potential for $\mathrm{U}(\mathrm{VI}), \mathrm{Np}(\mathrm{V})$, and $\mathrm{Eu}(\mathrm{III})$ to partition into the inner channels of zeolites is still being examined. Batch sorption experiments suggest that the ion exchange mechanisms may play a role in rate-limited sorption for the elements discussed here. Due to problems in scheduling Secondary Ion Mass Spectrometry of the single crystal samples, data could not be collected in time to present in this report. The data will be collected in the following weeks and will be included in a future report.

\section{References}

Bradbury M. H. and Baeyens B. (1997) A mechanistic description of Ni and Zn sorption on Na- montmorillonite .2. Modeling. Journal of Contaminant Hydrology 27(34), 223-248.

Davis J. A., Coston J. A., Kent D. B., and Fuller C. C. (1998) Application of the surface complexation concept to complex mineral assemblages. Environmental Science \& Technology 32(19), 2820-2828.

Doner H. E. and Zavarin M. (1997) The role of carbonates in trace and minor element chemistry. In Soils and environment : soil processes from mineral to landscape scale, Vol. Advances in geoecology 30 (ed. K. Auerswald, J. M. Bigham, and H. Stanjek), pp. 422. Catena Verlag.

Duff M. C. and Amrhein C. (1996) Uranium(VI) adsorption on goethite and soil in carbonate solutions. Soil Science Society of America Journal 60(5), 1393-1400.

Dzombak D. A. and Morel F. M. M. (1990) Surface complexation modeling : hydrous ferric oxide. Wiley.

Herbelin A. L. and Westall J. C. (1994) FITEQL, A computer program for determination of chemical equilibrium constants from experimental data. Department of Chemistry, Oregon State University.

Johnson J. W. and Lundeen S. R. (1997) GEMBOCHS thermodynamic datafiles for use with the EQ3/6 modeling package. Lawrence Livermore National Laboratory.

Kurbatov M. H., Wood G. B., and Kurbatov J. D. (1951) Isothermal adsorption of cobalt from dilute solutions. Journal of Physical Chemistry 55, 1170-1182. 
McKinley J. P., Zachara J. M., Smith S. C., and Turner G. D. (1995) The influence of uranyl-hydrolysis and multiple site-binding reaction on adsorption of U(VI) to montmorillonite. Clays and Clay Minerals 45(5), 586-598.

Ragnarsdottir, K.V., Graham, C.M., and Allen, .G.C. (1996) Surface chemistry of reacted heulandite determined by SIMS and XPS. Chemical Geology 131, 167-181.

Tompson A. F. B., Bruton C. J., and Pawloski G. A. (1999) Evaluation of the hydrologic source term from the underground nuclear tests in Frenchman Flat and the Nevada Test Site: The CAMBRIC test. Lawrence Livermore National Laboratory, UCRL-ID-132300.

Turner D. R. (1995) A uniform approach to surface complexation modeling of radionuclide sorption, pp. 103. Center for Nuclear Waste Regulatory Analyses, CNWRA 95-001.

Van Cappellen P., Charlet L., Stumm W., and Wersin P. (1993) A surface complexation model of the carbonate mineral-aqueous solution interface. Geochimica et Cosmochimica Acta 57, 3505-3518.

Zachara J. M., Resch C. T., and Smith S. C. (1994) Influence of humic substances on $\mathrm{Co} 2+$ sorption by a subsurface mineral separate and its mineralogic components. Geochimica et Cosmochimica Acta 58(2), 553-566.

Zachara J. M., Cowan C. E., and Resch C. T. (1991) Sorption of divalent metals on calcite. Geochimica et Cosmochimica Acta 55(6), 1549-1562

Zavarin, M., and Bruton, C. J. 1999a. Non-electrostatic surface complexation approach to modeling radionuclide migration at the Nevada Test Site: The role of iron oxides and carbonates. Migration '99, Lake Tahoe, NV, September 26-October 1 (UCRL-JC-133474-ABS).

Zavarin, M., and Bruton, C. J. 1999b. Non-electrostatic surface complexation approach to modeling radionuclide migration at the Nevada Test Site: The role of aluminosilicates. American Geophysical Union 1999 Fall Meeting, San Francisco, CA, December 13-17 (UCRL-JC-135644-ABS) 


\section{APPENDIX B. DATA COLLECTED FOR THE UGTA PROJECT IN CONJUNCTION WITH THE HYDROLOGIC RESOURCES MANAGEMENT PROGRAM IN FY 2000}

The following data were originally presented in the Hydrologic Resources Management Program and Underground Test Area Project FY 2000 Progress Report (Chapter 5) (Davisson et al., 2002). However, the calcite results were mentioned only in passing in Table 4 of this report. Below, we present the calcite data and modeling results in full.

\section{B.1 Introduction and Methods}

Batch sorption experiments for $\mathrm{Pu}(\mathrm{IV})$ and $\mathrm{Pu}(\mathrm{V})$ sorption to calcite were performed in calcite saturated waters equilibrated with atmospheric $\mathrm{CO}_{2}(\mathrm{~g})$ using a $\mathrm{pH}$ stating technique and adjusted to an ionic strength of 0.1 using $\mathrm{NaCl}$. The solutions were equilibrated with calcite mineral prior to sorption experiments to ensure calcite saturation during sorption experiments. Batch sorption experiments were performed between $\mathrm{pH}$ 7.5 and 9.75. From $\mathrm{pH} 7.5$ to 9.75 , the carbonate concentration increased from $2.2 \times 10^{-4}$ to $7.3 \times 10^{-2} \mathrm{~mol} / \mathrm{L}$ while the $\mathrm{Ca}^{2+}$ concentration decreased from $4.0 \times 10^{-2}$ to $8.5 \times 10^{-6}$ $\mathrm{mol} / \mathrm{L}$. Thus a decrease in $\mathrm{Pu}$ sorption at high $\mathrm{pH}$ would indicate competition between aqueous carbonate complexation in solution and sorption. A decrease in $\mathrm{Pu}$ sorption at low $\mathrm{pH}$ would indiate competition between $\mathrm{Ca}$ and $\mathrm{Pu}$ for surface sites. The major element composition of batch sorption solutions was estimated from thermodynamic calcite solubility when fitting data.

For $\mathrm{Pu}(\mathrm{IV})$ sorption experiments, $5.0 \times 10^{-9} \mathrm{~mol} / \mathrm{L} \mathrm{Pu}$ was reacted with $5.0 \mathrm{~g} / \mathrm{L}$ calcite $\left(0.262 \mathrm{~m}^{2} / \mathrm{g}\right.$ from BET measurement) as batch experiments. For $\mathrm{Pu}(\mathrm{V})$ sorption experiments, $1 \times 10^{-7} \mathrm{~mol} / \mathrm{L} \mathrm{Pu}$ was reacted with the same amount of calcite. The $\mathrm{Pu}$ remaining in solution was measured at 48 hours and 7 days. Sorption modeling was accomplished using the 7 day sorption data. Blanks were run in parallel in all experiments. Very little sorption to container walls was observed.

Figure B.1 presents the aqueous speciation of $\mathrm{Pu}(\mathrm{V})$ under the conditions of the calcite sorption experiments. $\mathrm{Pu}(\mathrm{V})$ speciation is dominated by $\mathrm{PuO}_{2}{ }^{+}$at low $\mathrm{pH}$ and the monocarbonate at intermediate $\mathrm{pH}$ and dicarbonate species at high $\mathrm{pH}$. Figure B.2 presents the speciation of $\mathrm{Pu}(\mathrm{IV})$ under the conditions of the calcite sorption experiments. The neutral $\mathrm{Pu}(\mathrm{OH})_{4}(\mathrm{aq})$ species dominates at low $\mathrm{pH}$ while a negatively charged hydroxycarbonate species dominates at high $\mathrm{pH}$. Given that sorption often decreases under conditions where negatively charged aqueous species dominate, the speciation data suggests that sorption of $\mathrm{Pu}(\mathrm{V})$ and $\mathrm{Pu}(\mathrm{IV})$ should decrease at high $\mathrm{pH}$.

Several assumptions were made in determining $\mathrm{Pu}$ sorption constants on calcite. The site density used in modeling sorption was determined from calculating the $\mathrm{Ca}$ positions along the 104 plane of calcite $\left(8.31 \times 10^{-6} \mathrm{~mol} / \mathrm{m}^{2}\right.$ or $\left.5 \mathrm{sites} / \mathrm{nm}^{2}\right)$. Also, only a single site type was assumed to react with $\mathrm{Pu}$ on the calcite surface. 
Calcite reactions were written as surface exchange reactions instead of surface complexation reactions. ${ }^{13}$ This is, in part, due to inadequate study of sorption on slightly soluble minerals such as calcite (as compared to the many numbers of iron oxide sorption studies, for example). Most calcite sorption modeling studies have assumed that cations sorb by exchange with Ca (Zachara et al., 1991; Doner and Zavarin, 1997). For example, the exchange between $\mathrm{Ca}$ and $\mathrm{Pu}^{4+}$ at the calcite surface can be written in the following form:

$>\mathrm{CO}_{3} \mathrm{Ca}^{2+}+\mathrm{Pu}^{4+} \Leftrightarrow>\mathrm{CO}_{3} \mathrm{Pu}^{4+}+\mathrm{Ca}^{2+}$

$\mathrm{K}=\frac{\left(>\mathrm{CO}_{3} \mathrm{Pu}^{4+}\right)\left(\mathrm{Ca}^{2+}\right)}{\left(>\mathrm{CO}_{3} \mathrm{Ca}^{2+}\right)\left(\mathrm{Pu}^{4+}\right)}$

where the concentration of $>\mathrm{CO}_{3} \mathrm{Ca}^{2+}$ is equal to the concentration of $\mathrm{Ca}$ sites on the surface. The above equation is equivalent, in form, to surface complexation. It is unusual only in that the sorbing ion is competing with $\mathrm{Ca}^{2+}$ for the surface sites. Section 2 of this report details the differences and similarities of the surface exchange and surface complexation models.

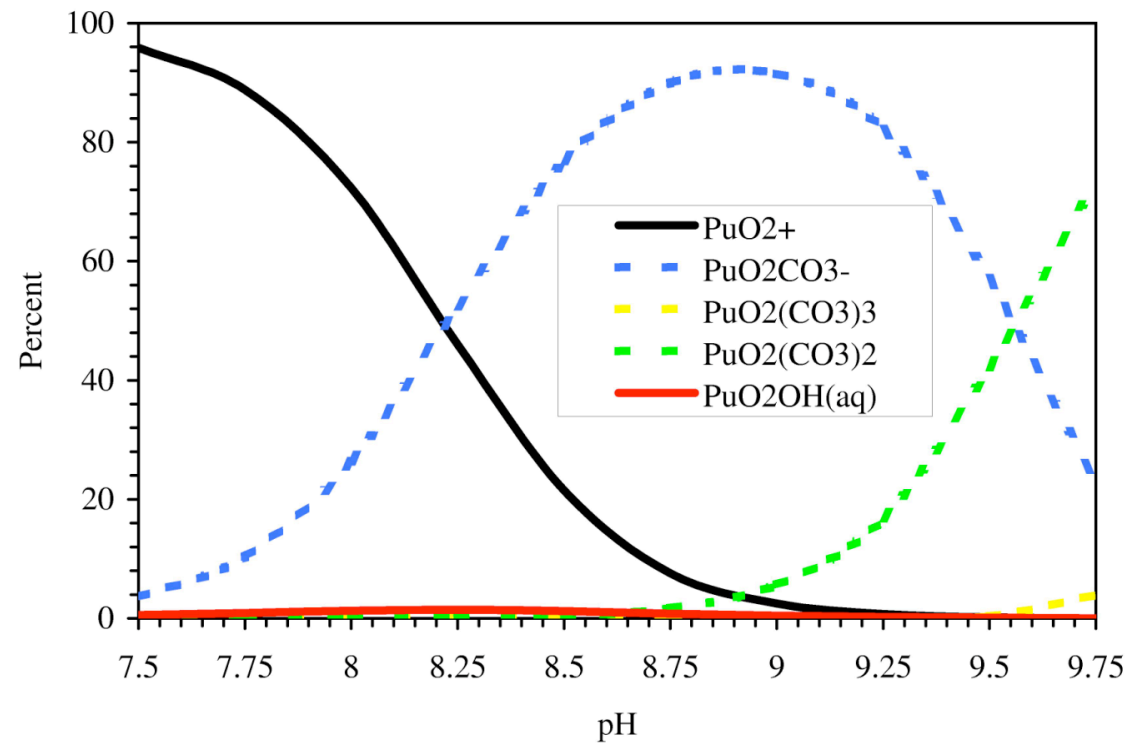

Figure B.1 Speciation of $\mathrm{Pu}(\mathrm{V})$ under conditions of calcite sorption experiments.

\footnotetext{
${ }^{13}$ A surface complexation model of the carbonate mineral-solution interface has been proposed (Van Cappellen et al., 1993) but has not been widely used to model sorption.
} 


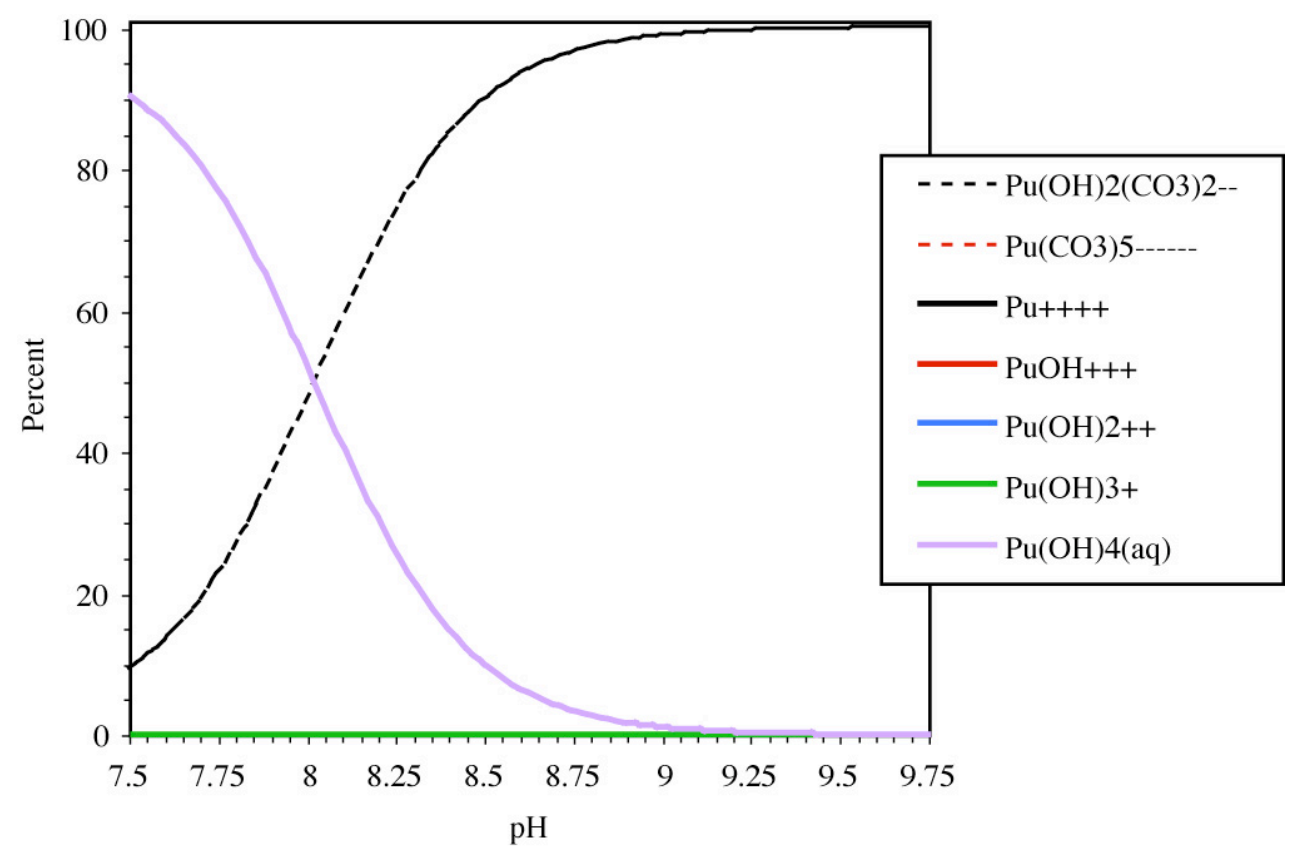

Figure B.2 Speciation of Pu(IV) under conditions of calcite sorption experiments.

\section{B.2 Results and Conclusions}

Table B. 1 contains the best fit $\log K$ values for the surface complexation (or surface exchange) of $\mathrm{Pu}$ on calcite. Figure B.3 presents the NEM SC model fit to $\mathrm{Pu}(\mathrm{IV})$ sorption on calcite. The free $\mathrm{Pu}$ in solution is plotted instead of the percent sorbed to better illustrate the model fit when $\mathrm{Pu}$ is predominantly associated with the calcite surface (i.e. high percent sorbed). The data point at $\mathrm{pH} 9.25$ was not used in the fit due to a potential error in the scintillation counting results and the associated $\mathrm{Pu}$ blank solution. As would be predicted from the aqueous speciation information, sorption at high $\mathrm{pH}$ is significantly reduced due to the formation of negatively charged aqueous $\mathrm{Pu}$-carbonate species. The small reduction in sorption at low $\mathrm{pH}$ is most likely due to the high concentration of $\mathrm{Ca}^{2+}$ in solution in equilibrium with calcite which competes for surface sites on calcite. The surface exchange of $\mathrm{Ca}^{2+}$ with $\mathrm{Pu}(\mathrm{OH})_{3}{ }^{+}$fit the sorption data across the entire $\mathrm{pH}$ range. In fact, both the decrease in sorption at low $\mathrm{pH}$ as a result of increasing aqueous $\mathrm{Ca}^{2+}$ and the decrease in sorption at high $\mathrm{pH}$ as a result of negatively charged aqueous $\mathrm{Pu}$-carbonate species formation was fitted. 
Table B.1. Best fit parameters for Pu sorption to calcite.

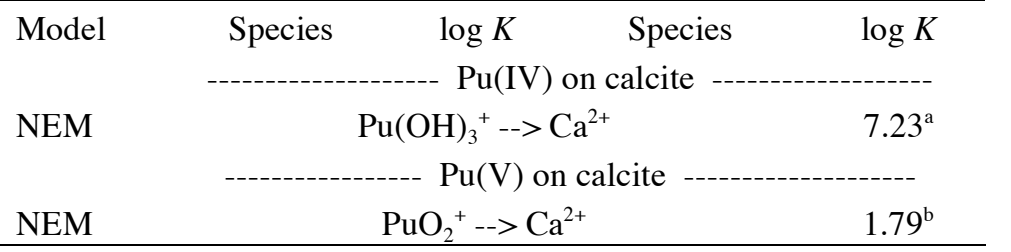

${ }^{a}$ This was reported as 2.61 in Davisson et al. (2002). This was an error which has been corrected here.

${ }^{\mathrm{b}}$ This was reported in Davisson et al. (2002) at 1.63. However, using an updated speciation database for $\mathrm{Pu}$-carbonate species (Appendix

C) resulted in a slight change in the fitted Log $K$.

The behavior of $\mathrm{Pu}(\mathrm{V})$ sorption to calcite as a function of $\mathrm{pH}$ is presented in Figure B.4. As in the case of $\mathrm{Pu}(\mathrm{IV})$ sorption, the decrease in sorption at high $\mathrm{pH}$ could be predicted from aqueous speciation data. The reduced sorption at low $\mathrm{pH}$, again, can be interpreted at competition between $\mathrm{PuO}_{2}^{+}$and $\mathrm{Ca}^{2+}$ for surface sites.

The NEM fit to the data can predict the significant decrease in sorption at high $\mathrm{pH}$. However, this fit would not be possible if a Pu-dicarbonate species was not included in our database. The $\mathrm{PuO}_{2}\left(\mathrm{CO}_{3}\right)_{2}{ }^{3-}$ species stability constant was based on the stability of $\mathrm{NpO}_{2}\left(\mathrm{CO}_{3}\right)_{2}{ }^{3-}$ because a published value for the Pu-dicarbonate species was not available. Uncertainty in the aqueous speciation of $\mathrm{PuO}_{2}{ }^{+}$directly affects the uncertainty in the surface speciation of $\mathrm{PuO}_{2}^{+}$. The same could be said for the $\mathrm{Pu}^{4+}$ data fits.

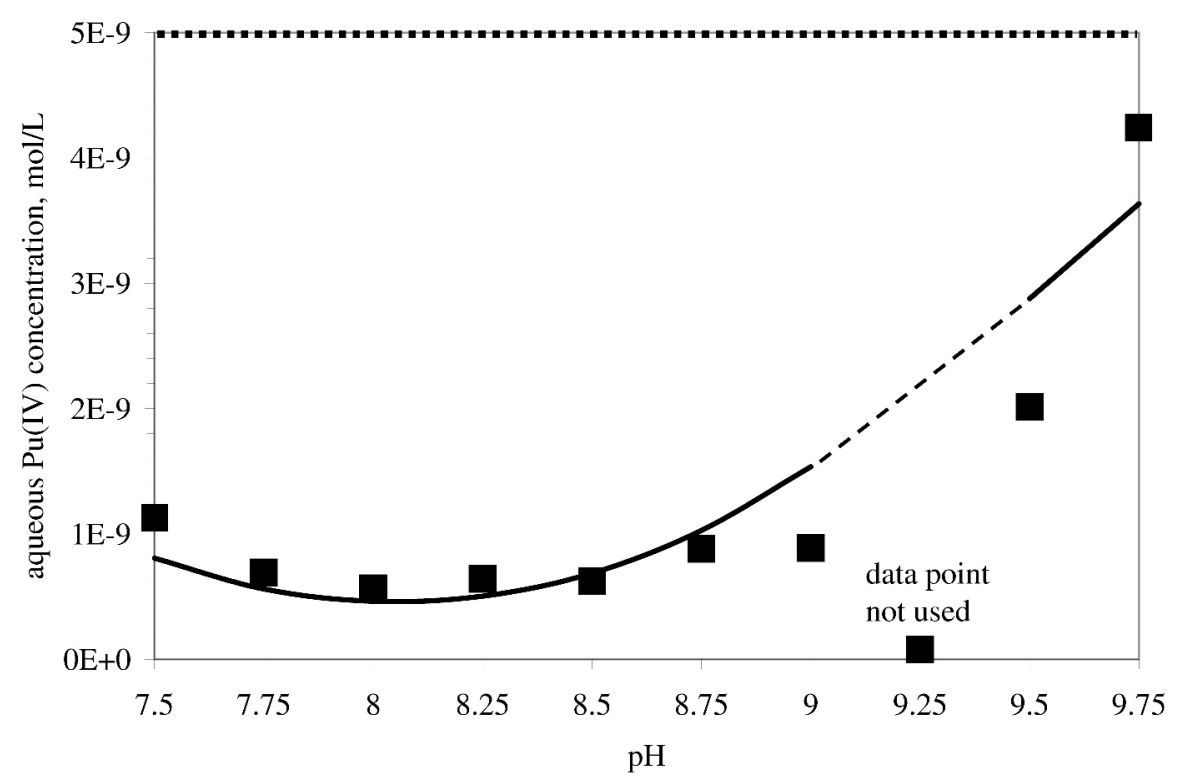

Figure B.3 Sorption data for $\mathrm{Pu}(\mathrm{IV})$ on calcite at 7 days. Dashed line represents the initial aqueous concentration in solution $\left(5 \times 10^{-9} \mathrm{~mol} / \mathrm{L}\right)$. The curve represents the fit to the sorption data using the non-elecrostatic model. 


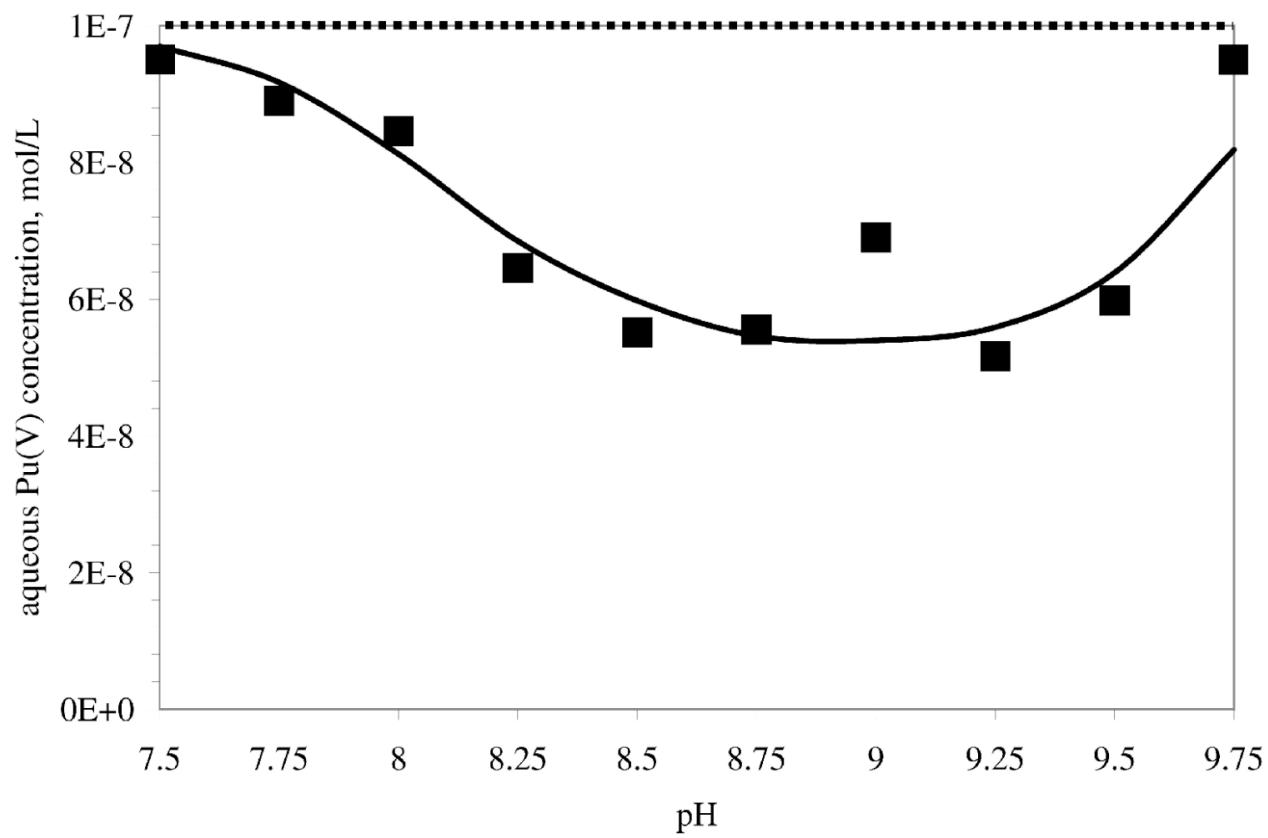

Figure B.4 Sorption data for $\mathrm{Pu}(\mathrm{V})$ on calcite at 7 days. Dashed line represents the initial aqueous concentration in solution $\left(1 \times 10^{-7} \mathrm{~mol} / \mathrm{L}\right)$. The curve represents the fit to the sorption data using the non-electrostatic surface exchange model. 


\section{APPENDIX C. AQUEOUS SPECIATION DATA USED IN DATA FITTING ROUTINES}

Thermodynamic data for aqueous species were taken from version com.V8.R6 of the GEMBOCHS thermodynamic database (Johnson and Lundeen, 1997) with revised and updated thermodynamic data as given in Pawloski et al. (2001) and noted below. Pu speciation data were taken, in part, from a recent compilation of Pu data (Lemire, 2001). The extended Debye-Hückel formulation (also known as the B-DOT model) was used to calculate activity coefficients of aqueous species (Bethke, 1996; Helgeson, 1969) in GIMRT simulations. Values of the ion size parameter (Bethke, 1996; Helgeson, 1969) for aqueous species added to the database were estimated by analogy to aqueous species of similar valence and ligand. Parameters used in the Debye-Hückel activity coefficient model are listed in Tables C. 1 and C.2. The Davies equation was used to calculate activity coefficients in the FITEQL data fitting routine. The Davies equation requires only one constant (C) which was set to 0.3 (Table C.2). 
Table C.1. Basis species used in thermodynamic database.

\begin{tabular}{lcc}
\hline & $\begin{array}{c}\text { Ion size } \\
\AA \dagger\end{array}$ & $\begin{array}{c}\text { Mol. Wt. } \\
\mathrm{g} / \mathrm{mol}\end{array}$ \\
\hline $\mathrm{H}_{2} \mathrm{O}$ & 3 & 18.0 \\
$\mathrm{Al}^{3+}$ & 9 & 27.0 \\
$\mathrm{Am}^{3+}$ & 5 & 243.0 \\
$\mathrm{Ca}^{2+}$ & 6 & 40.1 \\
$\mathrm{Cl}^{-}$ & 3 & 35.5 \\
$\mathrm{Cs}^{+}$ & 2.5 & 132.9 \\
$\mathrm{Eu}^{3+}$ & 5 & 152.0 \\
$\mathrm{Fe}^{2+}$ & 6 & 55.8 \\
$\mathrm{H}^{+}$ & 9 & 1.0 \\
$\mathrm{HCO}_{3}{ }^{-}$ & 4 & 61.0 \\
$\mathrm{~K}^{+}$ & 3 & 39.1 \\
$\mathrm{Mg}^{2+}$ & 8 & 24.3 \\
$\mathrm{Na}^{+}$ & 4 & 23.0 \\
$\mathrm{~Np}^{4+}$ & 5.5 & 237.0 \\
$\mathrm{Pu}^{4+}$ & 5.5 & 244.0 \\
$\mathrm{SO}_{4}^{2-}$ & 4 & 96.1 \\
$\mathrm{SiO}_{2}$ (aq) & 3 & 60.1 \\
$\mathrm{Sm}^{3+}$ & 9 & 150.4 \\
$\mathrm{Sr}^{2+}$ & 5 & 87.6 \\
$\mathrm{UO}_{2}{ }^{2+}$ & 4.5 & 270.0 \\
$\mathrm{O}_{2}($ aq $)$ & 3 & 32.0 \\
\hline$\dagger$ Ion size parameter used in Debye-Huckel activity coefficient \\
$\mathrm{model}^{2+}$ & & \\
& &
\end{tabular}

Table C.2. Parameters in extended Debye-Huckel activity coefficient model and Davies activity coefficient models.

\begin{tabular}{lc}
\hline Constants & $25^{\circ} \mathrm{C}$ \\
\hline $\mathrm{A}$ & 0.5114 \\
$\mathrm{~B}$ & 0.3288 \\
$\mathrm{~B}^{\circ}$ & 0.041 \\
$\mathrm{C}$ & 0.3 \\
\hline
\end{tabular}


Table C.3. Logarithm of equilibrium constants $(\mathrm{K})$ of aqueous reactions at $25{ }^{\circ} \mathrm{C}$.

\begin{tabular}{|c|c|c|}
\hline Reaction & $\log K$ & $\begin{array}{c}\text { Ion size } \\
\AA\end{array}$ \\
\hline $\mathrm{H}_{2} \mathrm{O}=\mathrm{OH}^{-}+\mathrm{H}^{+}$ & 14.0 & 3.5 \\
\hline $\mathrm{Al}^{3+}+2 \mathrm{H}_{2} \mathrm{O}=\mathrm{AlO}_{2}^{-}+4 \mathrm{H}^{+}$ & 22.2 & 4 \\
\hline $\mathrm{HCO}_{3}^{-}=\mathrm{CO}_{3}^{2-}+\mathrm{H}^{+}$ & 10.3 & 4.5 \\
\hline $\mathrm{HCO}_{3}^{-}+\mathrm{H}^{+}=\mathrm{CO}_{2}(\mathrm{aq})+\mathrm{H}_{2} \mathrm{O}$ & -6.345 & 4.5 \\
\hline $\mathrm{HCO}_{3}^{-}+\mathrm{H}^{+}=\mathrm{CO}_{2}(\mathrm{~g})+\mathrm{H}_{2} \mathrm{O}$ & 7.814 & - \\
\hline $\mathrm{Fe}^{2+}+0.25 \mathrm{O}_{2}(\mathrm{~g})+\mathrm{H}^{+}=\mathrm{Fe}^{3+}+0.5 \mathrm{H}_{2} \mathrm{O}$ & -7.8 & 9 \\
\hline $\mathrm{Fe}^{3+}+2 \mathrm{H}_{2} \mathrm{O}=\mathrm{FeO}_{2}^{-}+4 \mathrm{H}^{+}$ & 21.6 & 4 \\
\hline $\mathrm{Fe}^{3+}+2 \mathrm{H}_{2} \mathrm{O}=\mathrm{HFeO}_{2}{ }^{0}+3 \mathrm{H}^{+}$ & 12.0 & 3 \\
\hline $\mathrm{SiO}_{2}\left(\mathrm{aq}^{\prime}+\mathrm{H}_{2} \mathrm{O}=\mathrm{HSiO}_{3}^{-}+\mathrm{H}^{+}\right.$ & 9.6 & 4 \\
\hline $\mathrm{Ca}^{2+}+\mathrm{HCO}_{3}^{-}=\mathrm{CaCO}_{3}^{0}+\mathrm{H}^{+}$ & 7.0 & 3 \\
\hline $\mathrm{O}_{2}(\mathrm{aq})=\mathrm{O}_{2}(\mathrm{~g})$ & 2.898 & - \\
\hline $\mathrm{Sr}^{2+}+\mathrm{H}_{2} \mathrm{O}=\mathrm{SrOH}^{+}+\mathrm{H}^{+}$ & 13.3 & 3 \\
\hline $\mathrm{Sr}^{2+}+\mathrm{HCO}_{3}^{-}=\mathrm{SrCO}_{3}^{0}+\mathrm{H}^{+}$ & 7.46 & 3 \\
\hline $\mathrm{Sr}^{2+}+\mathrm{HCO}_{3}^{-}=\mathrm{SrHCO}_{3}^{+}$ & -1.18 & 3 \\
\hline $\mathrm{Eu}^{3+}+\mathrm{H}_{2} \mathrm{O}=\mathrm{EuOH}^{2+}+\mathrm{H}^{+}$ & 9.20 & 4 \\
\hline $\mathrm{Eu}^{3+}+2 \mathrm{H}_{2} \mathrm{O}=\mathrm{Eu}(\mathrm{OH})_{2}^{+}+2 \mathrm{H}^{+}$ & 14.86 & 4 \\
\hline $\mathrm{Eu}^{3+}+3 \mathrm{H}_{2} \mathrm{O}=\mathrm{Eu}(\mathrm{OH})_{3}{ }^{0}+3 \mathrm{H}^{+}$ & 24.13 & 4 \\
\hline $\mathrm{Eu}^{3+}+\mathrm{HCO}_{3}^{-}=\mathrm{EuCO}_{3}^{+}+\mathrm{H}^{+}$ & 2.41 & 4 \\
\hline $\mathrm{Eu}^{3+}+2 \mathrm{HCO}_{3}^{-}=\mathrm{Eu}\left(\mathrm{CO}_{3}\right)_{2}^{-}+2 \mathrm{H}^{+}$ & 7.67 & 4 \\
\hline $\mathrm{Eu}^{3+}+3 \mathrm{HCO}_{3}^{-}=\mathrm{Eu}\left(\mathrm{CO}_{3}\right)_{3}^{3-}+3 \mathrm{H}^{+}$ & 18.32 & 4 \\
\hline $\mathrm{Sm}^{3+}+\mathrm{HCO}_{3}^{-}=\mathrm{SmCO}_{3}^{+}+\mathrm{H}^{+}$ & 2.5 & 4 \\
\hline $\mathrm{Sm}^{3+}+2 \mathrm{HCO}_{3}^{-}=\mathrm{Sm}\left(\mathrm{CO}_{3}\right)_{2}^{-}+2 \mathrm{H}^{+}$ & 7.9 & 4 \\
\hline $\mathrm{Am}^{3+}+\mathrm{H}_{2} \mathrm{O}=\mathrm{AmOH}^{2+}+\mathrm{H}^{+}$ & 6.41 & 4.5 \\
\hline $\mathrm{Am}^{3+}+2 \mathrm{H}_{2} \mathrm{O}=\mathrm{Am}(\mathrm{OH})_{2}^{+}+2 \mathrm{H}^{+}$ & 14.11 & 4 \\
\hline $\mathrm{Am}^{3+}+3 \mathrm{H}_{2} \mathrm{O}=\mathrm{Am}(\mathrm{OH})_{3}{ }^{0}+3 \mathrm{H}^{+}$ & 25.72 & 4 \\
\hline $\mathrm{Am}^{3+}+\mathrm{HCO}_{3}^{-}=\mathrm{AmCO}_{3}^{+}+\mathrm{H}^{+}$ & 2.54 & 4 \\
\hline $\mathrm{Am}^{3+}+2 \mathrm{HCO}_{3}^{-}=\mathrm{Am}\left(\mathrm{CO}_{3}\right)_{2}^{-}+2 \mathrm{H}^{+}$ & 8.38 & 4 \\
\hline $\mathrm{Am}^{3+}+3 \mathrm{HCO}_{3}^{-}=\mathrm{Am}\left(\mathrm{CO}_{3}\right)_{3}^{3-}+3 \mathrm{H}^{+}$ & 15.82 & 4 \\
\hline
\end{tabular}


TABLE C.3 (continued)

\begin{tabular}{|c|c|c|}
\hline Reaction & $\log K$ & $\begin{array}{c}\text { Ion size } \dagger \\
\AA\end{array}$ \\
\hline $\mathrm{UO}_{2}{ }^{2+}+\mathrm{H}_{2} \mathrm{O}=\mathrm{UO}_{2} \mathrm{OH}^{+}+\mathrm{H}^{+}$ & 5.22 & 3 \\
\hline $\mathrm{UO}_{2}{ }^{2+}+2 \mathrm{H}_{2} \mathrm{O}=\mathrm{UO}_{2}(\mathrm{OH})_{2}{ }^{0}+2 \mathrm{H}^{+}$ & 10.31 & 3 \\
\hline $\mathrm{UO}_{2}{ }^{2+}+3 \mathrm{H}_{2} \mathrm{O}=\mathrm{UO}_{2}(\mathrm{OH})_{3}{ }^{-}+3 \mathrm{H}^{+}$ & 19.25 & 3 \\
\hline $\mathrm{UO}_{2}{ }^{2+}+\mathrm{HCO}_{3}{ }^{-}=\mathrm{UO}_{2} \mathrm{CO}_{3}{ }^{0}+\mathrm{H}^{+}$ & 0.67 & 4 \\
\hline $\mathrm{UO}_{2}{ }^{2+}+2 \mathrm{HCO}_{3}^{-}=\mathrm{UO}_{2}\left(\mathrm{CO}_{3}\right)_{2}{ }^{2-}+2 \mathrm{H}^{+}$ & 3.76 & 4 \\
\hline $\mathrm{UO}_{2}{ }^{2+}+3 \mathrm{HCO}_{3}{ }^{-}=\mathrm{UO}_{2}\left(\mathrm{CO}_{3}\right)_{3}{ }^{4-}+3 \mathrm{H}^{+}$ & 9.44 & 4 \\
\hline $\mathrm{Np}^{4+}+0.25 \mathrm{O}_{2}(\mathrm{~g})+1.5 \mathrm{H}_{2} \mathrm{O}=\mathrm{NpO}_{2}^{+}+3 \mathrm{H}^{+}$ & 9.9 & 4 \\
\hline $\mathrm{NpO}_{2}^{+}+\mathrm{H}_{2} \mathrm{O}=\mathrm{NpO}_{2} \mathrm{OH}^{0}+\mathrm{H}^{+}$ & 8.90 & 3 \\
\hline $\mathrm{NpO}_{2}^{+}+\mathrm{HCO}_{3}^{-}=\mathrm{NpO}_{2} \mathrm{CO}_{3}^{-}+\mathrm{H}^{+}$ & 5.73 & 4 \\
\hline $\mathrm{NpO}_{2}^{+}+2 \mathrm{HCO}_{3}^{-}=\mathrm{NpO}_{2}\left(\mathrm{CO}_{3}\right)_{2}^{3-}+2 \mathrm{H}^{+}$ & 13.66 & 4 \\
\hline $\mathrm{NpO}_{2}{ }^{+}+3 \mathrm{HCO}_{3}{ }^{-}=\mathrm{NpO}_{2}\left(\mathrm{CO}_{3}\right)_{3}{ }^{5-}+3 \mathrm{H}^{+}$ & 22.49 & 4 \\
\hline $\mathrm{Pu}^{4+}+\mathrm{H}_{2} \mathrm{O}=\mathrm{PuOH}^{3+}+\mathrm{H}^{+}$ & 0.5 & 3 \\
\hline $\mathrm{Pu}^{4+}+2 \mathrm{H}_{2} \mathrm{O}=\mathrm{Pu}(\mathrm{OH})_{2}{ }^{2+}+2 \mathrm{H}^{+}$ & 1.66 & 3 \\
\hline $\mathrm{Pu}^{4+}+3 \mathrm{H}_{2} \mathrm{O}=\mathrm{Pu}(\mathrm{OH})_{3}^{+}+3 \mathrm{H}^{+}$ & 4.62 & 3 \\
\hline $\mathrm{Pu}^{4+}+4 \mathrm{H}_{2} \mathrm{O}=\mathrm{Pu}(\mathrm{OH})_{4}{ }^{0}+4 \mathrm{H}^{+}$ & 8.85 & 3 \\
\hline $\mathrm{Pu}^{4+}+2 \mathrm{HCO}_{3}^{-}+2 \mathrm{H}_{2} \mathrm{O}=\mathrm{Pu}(\mathrm{OH})_{2}\left(\mathrm{CO}_{3}\right)_{2}^{2-}+4 \mathrm{H}^{+}$ & $2.76 \S$ & 3 \\
\hline $\mathrm{Pu}^{4+}+5 \mathrm{HCO}_{3}^{-}=\mathrm{Pu}\left(\mathrm{CO}_{3}\right)_{5}^{6-}+5 \mathrm{H}^{+}$ & 16.31 & 4 \\
\hline $\mathrm{PuO}_{2}^{+}+\mathrm{H}_{2} \mathrm{O}=\mathrm{PuO}_{2} \mathrm{OH}^{0}+\mathrm{H}^{+}$ & 9.73 & 3 \\
\hline $\mathrm{PuO}_{2}^{+}+\mathrm{HCO}_{3}^{-}=\mathrm{PuO}_{2} \mathrm{CO}_{3}^{-}+\mathrm{H}^{+}$ & 5.21 & 4 \\
\hline $\mathrm{PuO}_{2}{ }^{+}+2 \mathrm{HCO}_{3}{ }^{-}=\mathrm{PuO}_{2}\left(\mathrm{CO}_{3}\right)_{2}^{3-}+2 \mathrm{H}^{+}$ & $13.66^{\mathrm{a}}$ & 4 \\
\hline $\mathrm{PuO}_{2}{ }^{+}+3 \mathrm{HCO}_{3}{ }^{-}=\mathrm{PuO}_{2}\left(\mathrm{CO}_{3}\right)_{3}{ }^{5-}+3 \mathrm{H}^{+}$ & 26.00 & 4 \\
\hline
\end{tabular}

$\dagger$ Ion size parameter, used in Debye-Huckel activity coefficient model, for the aqueous complex formed by the basis species.

$\S$ Speciation constant derived from Rai et al. (1999).

${ }^{a}$ Estimated from reaction constant for $\mathrm{NpO}_{2}\left(\mathrm{CO}_{3}\right)_{2}{ }^{3-}$. 


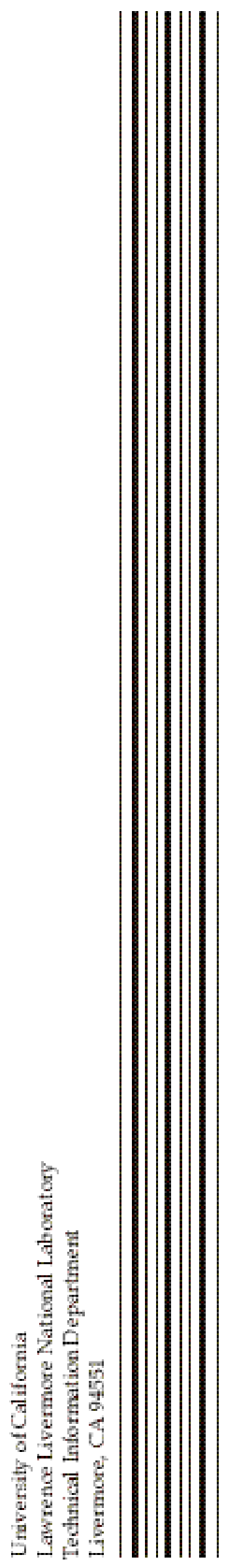

